\title{
IntechOpen
}

\section{Who Wants to Retire and Who Can Afford to Retire?}

Edited by Ingrid Muenstermann

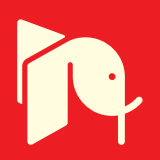





\section{Who Wants to Retire and Who Can Afford to Retire?}

Edited by Ingrid Muenstermann 

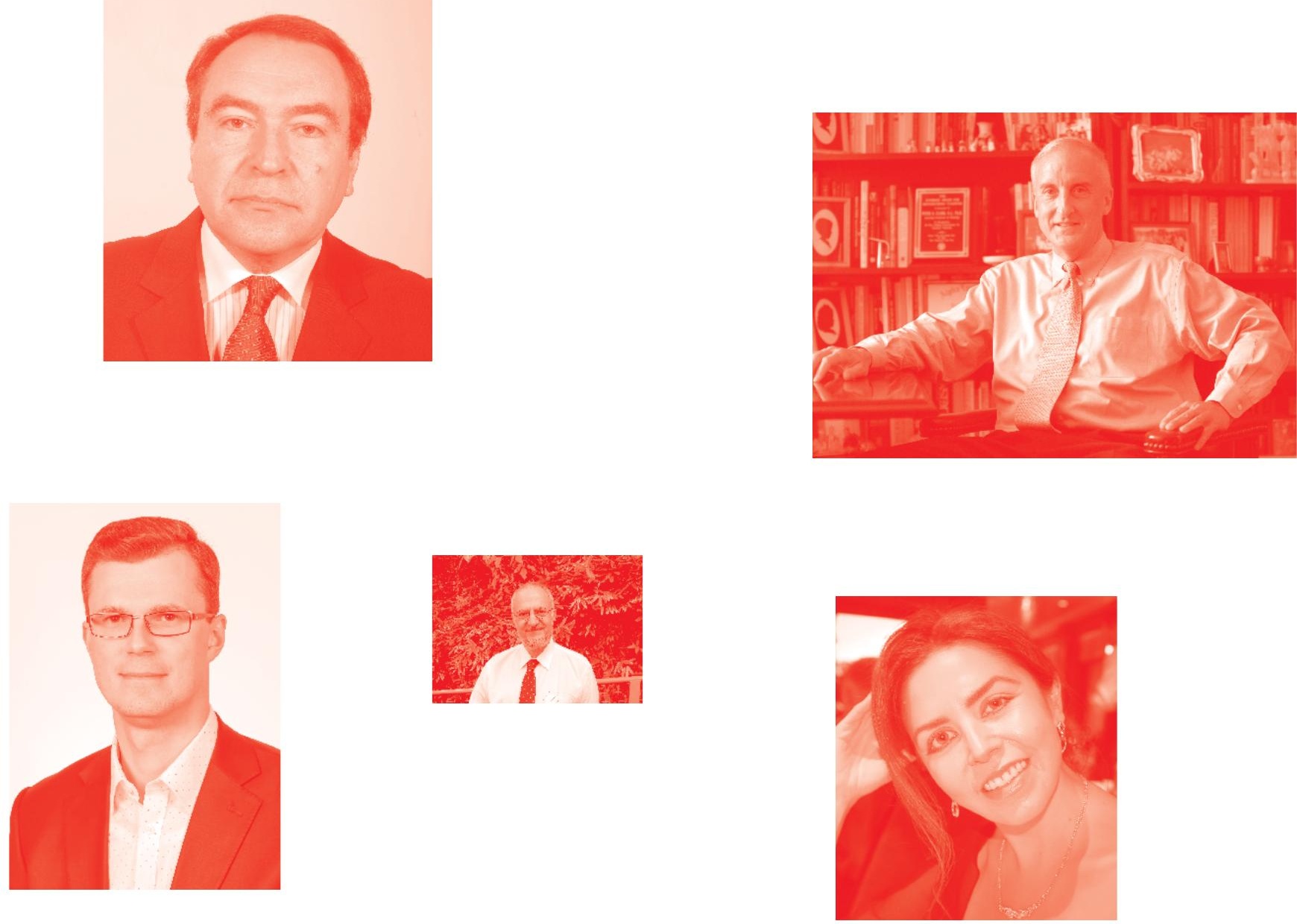

Supporting open minds since 2005
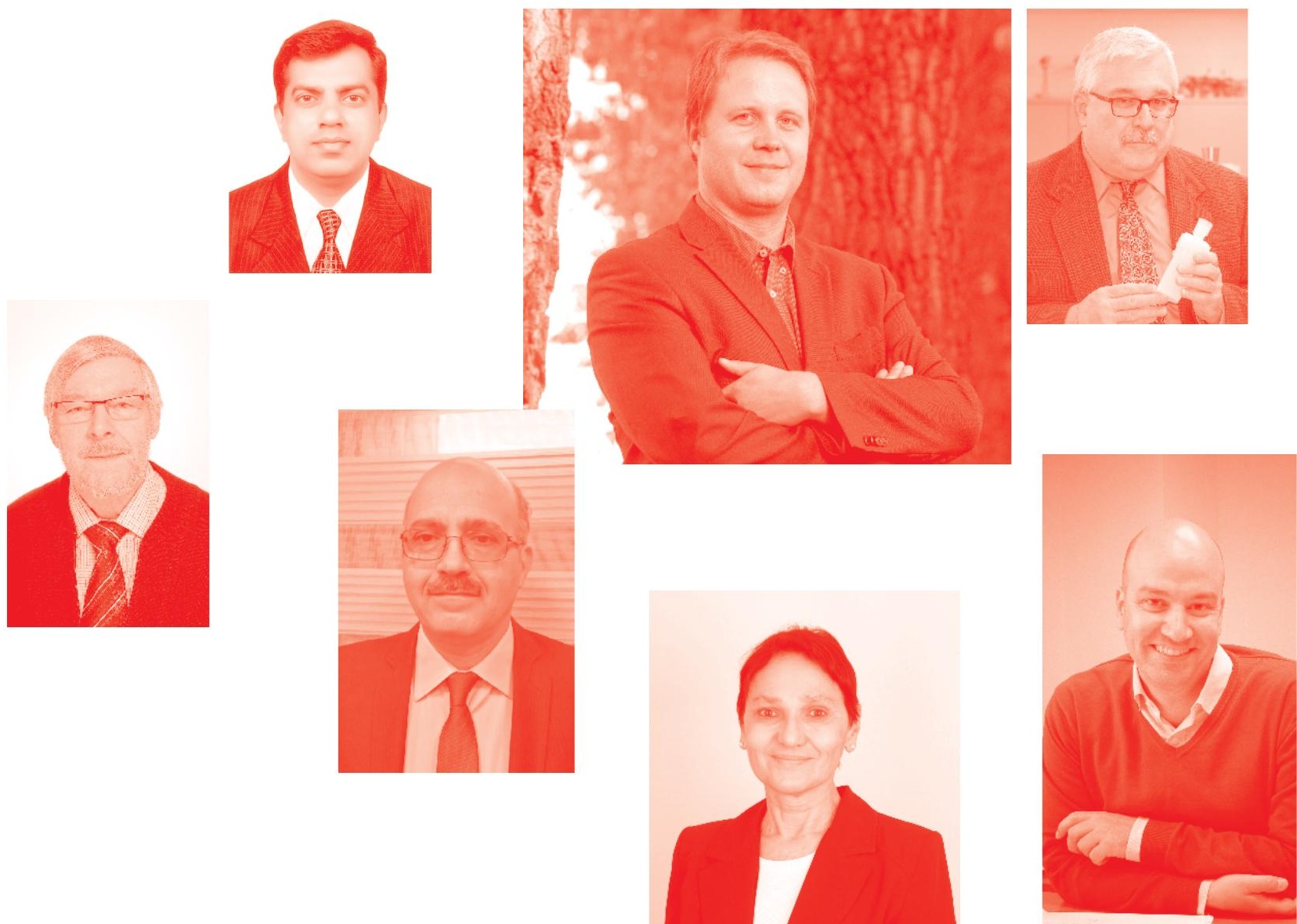
Who Wants to Retire and Who Can Afford to Retire?

http : //dx. doi. org/10.5772/intechopen. 77921

Edited by Ingrid Muenstermann

\section{Contributors}

Jorge Miguel Ventura Bravo, Anthony Asher, John De Ravin, Fang-Yi Huang, Monika Ardelt, Elena I. Kulikova, Veronica Sheen, Bernadene Erasmus, Peter Morey, Aida Isabel Tavares, Mursali Milanzi, Anselm Namala

\section{() The Editor(s) and the Author(s) 2020}

The rights of the editor(s) and the author(s) have been asserted in accordance with the Copyright, Designs and Patents Act 1988. All rights to the book as a whole are reserved by INTECHOPEN LIMITED. The book as a whole (compilation) cannot be reproduced, distributed or used for commercial or non-commercial purposes without INTECHOPEN LIMITED's written permission. Enquiries concerning the use of the book should be directed to INTECHOPEN LIMITED rights and permissions department (permissions@intechopen.com).

Violations are liable to prosecution under the governing Copyright Law .

\section{(cc) BY}

Individual chapters of this publication are distributed under the terms of the Creative Commons Attribution 3.๑ Unported License which permits commercial use, distribution and reproduction of the individual chapters, provided the original author(s) and source publication are appropriately acknowledged. If so indicated, certain images may not be included under the Creative Commons license. In such cases users will need to obtain permission from the license holder to reproduce the material. More details and guidelines concerning content reuse and adaptation can be found at http : //www . intechopen . com/copyright-policy. html .

Notice

Statements and opinions expressed in the chapters are these of the individual contributors and not necessarily those of the editors or publisher. No responsibility is accepted for the accuracy of information contained in the published chapters. The publisher assumes no responsibility for any damage or injury to persons or property arising out of the use of any materials, instructions, methods or ideas contained in the book.

First published in London, United Kingdom, 2020 by IntechOpen

IntechOpen is the global imprint of INTECHOPEN LIMITED, registered in England and Wales, registration number: 11086078 , 5 Princes Gate Court, London, SW7 2QJ, United Kingdom Printed in Croatia

British Library Cataloguing-in-Publication Data

A catalogue record for this book is available from the British Library

Additional hard and PDF copies can be obtained from orders@intechopen. com

Who Wants to Retire and Who Can Afford to Retire?

Edited by Ingrid Muenstermann

p. $\mathrm{cm}$.

Print ISBN 978-1-83962-476-6

Online ISBN 978-1-83962-477-3

eBook (PDF) ISBN 978-1-83962-478-0 


\section{We are IntechOpen, \\ the world's leading publisher of Open Access books}

\section{Built by scientists, for scientists}

\section{$5,100+$}

Open access books available

156

Countries delivered to
$126,000+$

International authors and editors

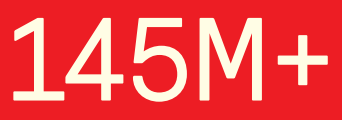

Downloads

Our authors are among the

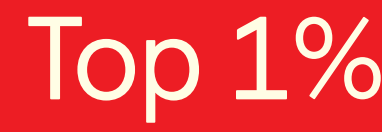

most cited scientists

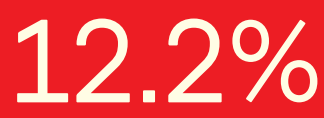

Contributors from top 500 universities

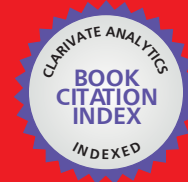

WEB OF SCIENCE ${ }^{\mathrm{TM}}$

Selection of our books indexed in the Book Citation Index in Web of Science ${ }^{\mathrm{TM}}$ Core Collection (BKCI)

Interested in publishing with us?

Contact book.department@intechopen.com

Numbers displayed above are based on latest data collected.

For more information visit www.intechopen.com

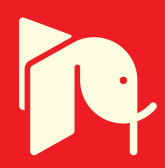





\section{Meet the editor}

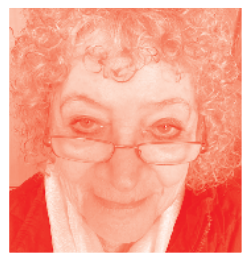

Ingrid Muenstermann was born in 1938 in Hamburg, Germany, and settled in Australia in 1973. For many years she worked as a secretary in the medical field, but discovered the rewards of becoming an academic after achieving a $\mathrm{PhD}$ in Social Sciences. She is a sociologist at heart and is casually employed at Flinders University of South Australia. Dr. Muenstermann has a special interest in all things equity. Of particular interest have been, and still are, new settlers to Australia with a special focus on German immigrants. The decline of the natural environment and increased societal self-interest led her to consider universal social responsibility. Lately the concept of aging and how to retire gracefully, that is, to maintain a certain standard of living, have been on her mind. She hopes to research different areas of life in the not too distant future. 



\section{Contents}

$\begin{array}{lll}\text { Preface } & \text { XIII }\end{array}$

Chapter $1 \quad 1$

Addressing the Pension Decumulation Phase of Employee Retirement Planning

by Jorge Miguel Ventura Bravo

Chapter 2

The Age Pension Means Tests: Contorting Australian Retirement by Anthony Asher and John De Ravin

Chapter 3

Pathways to Retirement in Taiwan: Do Ethnicity and Cohort Matter?

by Fang-Yi Huang and Monika Ardelt

Chapter 4

Alternatives to Serve the Interests of Russian Pensioners

by Elena Ivanovna Kulikova

Chapter 5

Called to Plan: Changing Patterns and Perceptions of Retirement

for Australian and New Zealand Faith-Based Ministers

by Bernadene Erasmus and Peter John Morey

Chapter 6

Lifestyles, Health, and Life Satisfaction among the Portuguese Seniors by Aida Isabel Tavares

Chapter 7

Retired but Not Tired: Entrepreneurial Motives and Performance among Retired Public Servants in Tanzania

by Anselm Namala and Mursali A. Milanzi

Chapter 8

The End of the Retirement "Age": How the New World of Work Is Transforming the Old World of Retirement by Veronica Sheen 



\section{Preface}

I will start with some personal reflections. This book owes its creation to a person who is well over the usual age of retirement, refusing to let go of what has been learnt during life, but more so what has been studied and acquired in a relatively short academic career. There is also the fear of dementia and the belief that, once retired, thought processes will decline; and there is the necessity for some income support if a certain lifestyle is to be maintained. As the reader of this book will find, there is no right or specific age to retire; much depends on personal perspectives despite rules and regulations of the country a person lives in. The usual retirement age in Organization for Economic Co-Operation and Development countries (OECD) is 65 years, but life expectancy is increasing ${ }^{1}$ and governments in the countries dealt with in this book consider delaying the receipt of the age pension. In Australia, for people born up until 1952, the retirement age is 65 years; for people born in 1953, it is 65 years and 6 months; and for those born from 1957 on, the retirement age is 67 years. How do people prepare for their retirement? Employer and employee pay a certain percentage of the earnings or wages into a fund. The public pension fund is regulated under public sector law, whereas a private pension fund is regulated under private sector law. As the content of this book demonstrates, different countries have different rules and regulations. Apart from considering measures on how to best save for one's retirement, on how governments can improve the distribution of age pension, or how to transform the old world of retirement, well-researched contributions from specialists in Portugal, Russia, Taiwan, Tanzania, Australia and Australia / New Zealand provide an interesting overview.

The first chapter by Jorge Miguel Bravo, "Addressing the Pension Decumulation Phase of Employee Retirement Planning," considers increasing longevity and the challenges it provides for societal institutions providing retirement income, healthcare, and long-term care services. It presents a retirement portfolio, sections on the decumulation menu of pensions, and information on sharing investment and longevity risk (participating longevity-linked life annuities), and on welfare of pension decumulation strategies. Several tables and graphs demonstrate the

\footnotetext{
${ }^{1}$ Max Roser, Esteban Ortiz-Ospina \& Hannah Ritchie (2013) - Life Expectancy. Published online at OurWorldInData.org. Retrieved from: https://ourworldindata.org/life-expectancy

* The World Bank Data, Retrieved from: https://data.worldbank.org/indicator/SP.DYN.LE00.

$\mathrm{IN}$ ?locations $=\mathrm{TZ}$

** United Nations, Retried from: <www.macrotrends.net/countries/TWN/taiwan/life-expectancy'> Taiwan Life Expectancy 1950-2020</a>
}

\begin{tabular}{lll}
\hline & 1960 & 2015 \\
\hline Australia & 70.9 & 82.5 \\
\hline New Zealand & 71.1 & 81.7 \\
\hline Portugal & 63.2 & 81.0 \\
\hline Taiwan** & 63.8 & 79.6 \\
\hline Russia & 66.2 & 71.3 \\
\hline Tanzania* & 43.9 & 65.0 \\
\hline
\end{tabular}


statistical underpinnings. The main pension decumulation options are explained by consumers' behavior and objectives (utility theory) using a Monte-Carlo simulation approach calibrated to US financial market and mortality data. The results suggest that purchasing a capped participating longevity-linked life annuity at retirement results in superior welfare outcomes when compared with classical annuitization and non-annuitization decumulation strategies.

Chapter 2, "The Age Pension Means Tests: Contorting Australian Retirement” by Anthony Asher and John De Ravin, critically examines the Australian retirement income system, which is made up of two main pillars: the means tested Age Pension and Superannuation. The Age Pension is a welfare benefit that is means tested and funded from general government revenue. The Superannuation system consists mainly of privately administered funds in which members have investment accounts into which mandated contributions are paid by the employer as well as the employee. Members are able to take tax-free lump sums from the age of 60 years, which is of concern to the authors. A third pillar consists of voluntary savings, including the home. There are currently two separate components of the means tests, the income test and the assets test, the latter treating homeowners differently to non-homeowners; an example being that non-homeowners with $\$ 1$ million in assets will get no Australian Pension, whereas homeowners with a house of that value will draw the whole Australian Pension. Since there is a strong incentive to draw down quickly on superannuation and to move assets into the family home, the authors recommend changes to the asset test taper rate or to abolish the asset test and convert superannuation into an income stream. Both suggestions will be challenging to implement because they involve personal responsibility and politically a bi-partisan approach.

Chapter 3, "Pathways to Retirement in Taiwan: Do Ethnicity and Cohort Matter?" by Fang-Yi Huang and Monika Ardelt, makes comparisons between "Mainlanders," who emigrated from mainland China to Taiwan during the 1940s and 1950s after losing the Chinese Civil War, and "non-Mainlanders," consisting of Southern Mins, Hakka, and several groups of Indigenous people, and their access to education, job opportunities, health services, and the age or possibility of retiring. The chapter assesses the public and the private sectors of work and the amount of pensions received by different cohorts of people. "Mainlanders" have created many chances in the public sector of work and out-performed "non-Mainlanders" in major aspects of their lives. The author uses the cumulative advantage and disadvantage theory, which considers economic inequality across the life course, and points out that "non-Mainlanders" have been disadvantaged throughout their lives; therefore, ethnicity is an important issue to determine the retirement age. Suggested changes include: (1) policy makers should take occupational categories, occupational sectors, and income replacement into consideration to build a new and more equitable pension scheme; (2) the same retirement eligibility age should be applied for blue-collar workers in the private sector as to public sector workers; and (3) financial assistance should be offered to disadvantaged groups.

Chapter 4, "Alternatives to Serve the Interests of Russian Pensioners," takes the reader to Russia. Author Elena I. Kulikova looks at statistical data of the Russian labor market and uses it to convince the reader of the importance of practical changes to the pension system. The author refers to the Universal Declaration of Human Rights, the International Covenant on Economics, and to social and cultural rights in relation to economic equity in old age. The issue is complex; Russia consists of 85 regions and each region has different laws, including different amounts of 
pensions and minimum wages. It seems that the rule of "one size fits all" cannot be applied. In 2002, a legislative change was introduced to the state pension, and working citizens (born in 1967 and later) had to contribute on a mandatory basis; the first recipients of that system would be people retiring in 2027. This change was to create pension institutions and management bodies, to establish a system for investing pension funds in the financial market through non-state pension funds. There was the idea to design a non-state pension system for the formation of corporate (voluntary) pensions, and to increase economic opportunities for citizens in relation to their retirement. That system was also to reduce the amount of state obligation towards its citizens. The author argues that up until 2014, mandatory savings (pension savings) and voluntary (corporate) pensions (pension reserves) provided for the influx of new pension savings into private pension funds and management companies. Now, however, the government is trying to transform the funded pension from mandatory to voluntary in order to encourage the activities of private investors in the financial market. The government also intends to solve the issue of pension capital formation. According to Russian law, pension funds are not the property of the citizens, despite the fact that the premium for the state pension is paid to the Pension Fund of Russia at the amount of 22 percent of a citizen's payroll (paid through an employer who acts as a withholding agent). The state, and not the citizen, owns these funds. The government has taken the liberty to redistribute funds from the pension reserves to other sectors of the economy. The author finds that principles proposed by the OECD have been implemented in Russia, but argues that because of constant reform of the pension system, the level of citizens' confidence in the pension system is decreasing. An important point is that the present pension rate should be 40 percent of the previous earnings; however, it is usually only about 30 percent. The author believes that the funded pension Russian citizens will start receiving in 2027 will significantly increase the pension coverage and that this money should be handled with more care. Russian citizens can choose whether they pay into and get a state pension (paid from the 22 percent of the payroll) or contribute to and receive an income comprising a state pension and a funded pension. It is concluded that an acceptable standard of living cannot be achieved by the present system. Suggestions include a proposal of optimal investment mechanisms and improvement of social support for citizens.

Chapter 5, "Called to Plan: Changing Patterns and Perceptions of Retirement of Australian and New Zealand Faith-Based Ministers" by Bernadette Erasmus and Peter John Morey, looks at personal and professional factors affecting retirement perceptions in age-related differences of faith-based ministers in the southern hemisphere. Previously, faith-based ministers followed a line that God would take care of them in retirement; today they are promoting a more active role in preparing for their retirement. The question is, what changes have occurred in recent times and how does this specific group of people fit into modern society? From a theoretical point of view, the continuity theory (R. C. Atchley, 1989) is applied as well as career and retirement theories and their relevance for older workers across cultures (M. C. Lytle, P.F. Foley and E. W. Cotter, 2015). The methodology is a cross-sectional, retrospective survey involving 228 working Seventh-Day Adventist Ministers in Australia and New Zealand. The survey consisted of six different elements in relation to personal demographics, physical and mental health, psychological stress, the importance of work, retirement planning, personal resilience, and aspects of ministry as a career, and the "calling" of the ministers' work. The participants were then asked how prepared they were for retirement, how confident they were that retirement will be a positive season, how satisfied they were with the planning of retirement, and what factors would determine 
their retirement. The response to the inquiry into personal and professional factors affecting retirement indicated that these ministers rated their cognitive health very highly. They also regarded well-being, personal resilience, and their ability to plan for the future as relatively high. The importance of work was also highly rated. Their retirement was not seen as an end of ministry but rather as a time to move into a different ministry orientation. Anxiety about aging was rated in the mid-range. In terms of financial and social resources for retirement, the social component was rated highly but, in contrast, the financial component received a low rating. Age group differences (younger than 50 years of age and older than 50 years of age) determined that the older age group rated their psychological stress significantly lower and their financial retirement resources significantly higher than their younger colleagues did. Interesting is that for both groups financial resources were the strongest positive predictor of perceptions of preparedness for retirement. The point is made that "aging is not what it used to be," but that longer life expectancy and large numbers of people retiring has far-reaching consequences on any level of society. The authors recommend a multi-focal lens to recognize the different types of retirees and their different needs because they are not a homogenous group. This then necessitates consideration of culture specific factors and awareness of contextual influence in age-differentiated approaches.

Chapter 6, "Lifestyles, Health and Life Satisfaction among the Portuguese Seniors" by Aida Isabel Tavares, is based on the Portuguese National Health Survey of 2014 and grounded in European Union guidelines (Commission Regulation (EU) No. 141/2013). Opinions of 5701 Portuguese seniors who are 65 years of age and older are considered. The determinants of health include education and income, the independent variables are self-assessed health and life satisfaction, and the dependent variables are grouped in demographics, socio-economic status, health and physical conditions, and lifestyle variables. In 2018, life expectancy at birth was 78.3 years for men and 84.5 years for women. This research demonstrates that not all lifestyle variables explain sufficiently the self-assessed health and life satisfaction; some very interesting results emerged. People who smoke and drink alcohol frequently reported a good health status. A good health status was also reported by those who exercise frequently. Further, people reporting to eat unhealthy food and drinking alcohol frequently tended to report greater life satisfaction than those reporting frequent physical exercise. The author argues that despite reporting a good health status and life satisfaction, the Portuguese people could improve their longevity by receiving better education and a more generous retirement pension.

Chapter 7, "Retired but not Tired: Entrepreneurial Motives and Performance among Retired Public Servants in Tanzania," is written by Anselm Namala and Mursali A. Milanzi. Tanzania has a growing number of public service retirees who venture into business operations; however, about 50 percent are not generating a profit and 21 percent collapse within three years of operation. The entrepreneurial motives include seeking means of income, aiming to become active and overcoming postretirement boredom, and sustaining life after retirement. The authors assessed the performance of ninety randomly selected public servants who retired between 2012 and 2016 and established a business. The goal of the study was to provide an understanding of entrepreneurial performance of retired public servants in a developing economy. From a theoretical perspective, the resource-based perspective is used; a perspective that is based on the tenet that firms within an industry are heterogeneous in terms of resource ownership and that the resources are imperfectly mobile across firms. The study is based on a cross-sectional survey where sex, education, age, family size, motive, business sector, capital, 
and planning were assessed. Of ninety surveys, eighty-six were used. The main motivation to establish a business was the availability of financial capital (lump sum payments after retirement) and the availability of farm products intended for sale. The study established that the majority of businesses were not performing well; financial losses were recorded for three consecutive years. Four factors were important in relation to business performance as measured by business profitability: the age of starting a business, the educational level of the owner, the source of capital, and business preparation / planning. The authors recommend that (1) governments and pension funds need to establish retirement programs to prepare public servants for post-retirement careers; and (2) public servants should embrace a saving culture while still in employment.

Chapter 8, “The End of the Retirement 'Age': How the New World of Work is Transforming the old World of Retirement" by Veronica Sheen, puts forward a well-debated idea. Like the chapters before it, this one looks at the future of retiring as well as considers advanced technologies and the influence of the Coronavirus in relation to the new world. Most importantly, this chapter suggests a universal basic income. It asks the interesting question whether retirement is a relevant concept in the twenty-first century. The chapter argues that retirement has passed its "use by" date and presents three very important issues impacting our concepts of retirement. First, there is increasing inequality due to the loss of standard, middle-level jobs that enabled workers to have a continuous trajectory over their working lives, ending in a retirement at a certain age and eligibility for pension incomes. Second, the future of work is influenced by old concepts of jobs and employment as new technologies not necessarily replace people but impact on how work is structured. Third, the concept of retirement is transformed and becoming irrelevant in the new world of work, and social protection systems need to adapt to this. The future of work and the possibility of retiring are highly unpredictable, but predictions are that highly paid and asset-rich individuals will be able to retire as they wish; that there is a group of people who will be working well into their later years because of high levels of work satisfaction; new technologies may provide possibilities for ongoing work into later ages; and that certain professions and occupations (doctors, lawyers, teachers, accountants) will be ensured in the new world of work even though these too are threatened by new technologies. A more positive perspective is provided in relation to service workers and for people servicing households (trades). Taking empirical and literary evidence into account and considering the "compelling argument ... that the structure of jobs, work and employment is in process of being obliterated in the new world of work," the author presents the case for a universal basic income. She recognizes that there may be problems in its implementation, but the advantages she presents outweigh the disadvantages. A universal basic income would eliminate the need for specialized aged pension access rights through retirement-age policy stipulation. The income would be accessible to all and ensure adequate income for everyone regardless of workforce status and engagement, which is certainly something to think about.

Dr. Ingrid Muenstermann 



\title{
Addressing the Pension Decumulation Phase of Employee Retirement Planning
}

\author{
Jorge Miguel Ventura Bravo
}

\begin{abstract}
Longevity increases and population ageing create challenges for all societal institutions, particularly those providing retirement income, healthcare, and longterm care services. At the individual level, an obvious question is how to ensure all retirees have an adequate, secure, stable, and predictable lifelong income stream that will allow them to maintain a target standard of living for, however, long the individual lives. In this chapter, we review and discuss the main pension decumulation options by explicitly modelling consumers' behaviour and objectives though an objective function based on utility theory accounting for consumption and bequest motives and different risk preferences. Using a Monte-Carlo simulation approach calibrated to US financial market and mortality data, our results suggest that purchasing a capped participating longevity-linked life annuity at retirement including embedded longevity and financial options that allow the annuity provider to periodically revise annuity payments if observed survivorship and portfolio outcomes deviate from expected (or guaranteed) values at contract initiation deliver superior welfare results when compared with classical annuitization and non-annuitization decumulation strategies.
\end{abstract}

Keywords: retirement planning, pensions decumulation, longevity-linked life annuity, risk-sharing, income drawdown, financial advice

\section{Introduction}

Longevity increases and population ageing create challenges for all societal institutions, particularly those providing retirement income, healthcare, and longterm care services. Empirical results show that longevity improvements are not homogeneous across all socioeconomic groups (see, e.g., [1-4]). At the individual level, an obvious question is how to ensure all retirees have an adequate, secure, stable, and predictable lifelong income stream that will allow them to maintain a target standard of living for, however, long the individual lives. The answer to this question is not linear and depends on several factors such as the role of occupational/personal pensions, defined benefit (DB) or defined contribution (DC) nature, minimum income guarantees, social networks (e.g., family structure and interconnectedness, informal care networks), institutional and government regulations and interventions (e.g., on the design of the pension system architecture, on the mandatory or optional nature of contributions, on auto- enrolment, on labour 
income and pensions taxation), on individual preferences (e.g., regarding continuing to work after retirement, bequest, lifecycle planning), and family background and family shocks (e.g., inheritances, divorce) that prevent accumulation or accelerate decumulation, financial system development (e.g., the existence of efficient capital and insurance markets), or the risks involved in the generation of retirement income (e.g., investment, inflation, contribution, political, longevity, liquidity, behavioural). This also depends on general policy goals and constraints on fiscal policy, old-age poverty, tax neutrality over the life cycle, redistribution objectives, intergenerational fairness, or the political economy of an ageing society.

Planning for retirement requires workers to clearly understand their age-specific needs, vulnerabilities, and preferences at old age, which are certainly not the same during working life. The likelihood of experience disrupting life events such as experiencing changes in physical and mental health that anticipate retirement or generate some impairment, losing a partner that contributed to the households regular budget, caring for a spouse or other family members, changing housing, changing jobs and starting a new career at old age must be part of the retirement planning equation. Individuals must fully understand their financial goals, the expected income (and services) sources they anticipate in the accumulation and decumulating phases and be aware of the risks they are willing to take and the ones they want to insure, diversify, or hedge. Typical old-age financial needs include having a minimum guaranteed income stream that smoothens the transition from working life to retirement and protects from the eroding effect of inflation on the purchasing power of money, having an extra income to guarantee access to healthcare and long-term care services (medicines, dental care, care at home, nursing home care), bequeathing (cash inheritance, housing wealth, grandchildren's education, funeral expenses, donations), or paying for life style activities (e.g., travelling). To fund for longer lives, people will ultimately rely on a retirement wallet combining state, employer-based or personal pensions, social institutions, family, own savings (including housing wealth), continued labour income, and insurance sources, with weights determined by both personal and institutional circumstances $[5,6]$.

The role of funded individual retirement provisions has increased over recent decades, as a result of systemic reforms of public pension schemes (move from NDB schemes towards FDC schemes, introduction of private savings pillars, for example, in Sweden, Poland), the decreasing public generosity of public annuities as a result of fiscally driven public pension reforms (e.g., Portugal, Spain), policies encouraging voluntary supplementary saving and disbursement via life annuity (e.g., Australia and New Zealand), private schemes switching from existing FDB schemes to FDC, and the "Pension freedoms" reform introduced in the UK in April 2015 providing greater flexibility and choice over how to access their defined contribution (DC) pension pots $[7,8]$. The way individuals chose to decumulate their assets is one of the most important decisions they will make as they approach and enter into retirement. The decumulation process involves in some cases a oneoff decision, made at the time of retirement (e.g., when an individual uses his entire wealth to pay the single premium of a standard life annuity or of a longevity-linked life annuity), but quite often involves a sequence of ad-hoc or programmed decisions spanned throughout the whole retirement period (e.g., when individuals opt to manage their assets and follow some simple or more complex drawdown rules, or when they simply choose not to divest and continue to accumulate savings).

The decumulation strategy may include investment, inflation, longevity, and other biometric risk guarantees, but often requires the individual to decide upon how much to withdrawn periodically from the pension pot to live on, particularly when public or private pension scheme benefits are not enough to pay regular 
expenses, considering the remaining lifetime, and deciding on how to allocate the remaining funds during retirement [9]. Traditional disbursement product options include level (nominal or real) life annuity contracts, programmed drawdown schemes and lump sum payments, and several hybrid risk-sharing solutions like longevity-linked life annuities (see, e.g., [10-12]), modern Tontines [13], or a Tonnuity [14]. The different decumulation strategies aim to minimise longevity and investment risks while optimising against a given objective function (maximise consumption, maintain purchasing power of money, eliminate ruin chances, mitigating volatility in income streams, balance between guaranteed income sources and liquid assets, bequest).

For decades, ensuring pension scheme members have saved enough for their retirement was the main concern for employers and pension trustees. Yet, in recent years, there is also growing interest in the payout phase of pensions. This is explained by the fact that the nature of retirement is changing from a one-off decision to a gradual transition with more flexible combinations between continued labour income and pension benefits, by expanding retirement planning horizons due to longevity increases, by the lack of traditional financial instruments like level annuities, and by the number of available options at retirement which demand financial knowledge. Trustees and employers are expected to meet the challenge of preparing members for retirement and actively emphasise the members the advantages of getting financial advice from a suitably qualified adviser if necessary.

The search for the appropriate decumulation option for accumulated individual retirement savings has to take account of a number of particularities in individual preferences and enabling environment, including differences in preferences for annuities, income drawdowns of lump sum payments, including differences in preferences for consumption and bequest, spouses', and dependants' benefits, differences in the exposure to uninsurable risks/shocks that affect decumulation (divorce, death of a partner and effects on wealth level, composition, service access, financial crisis and effects on asset level/composition, health shocks, long-term care), differences in access to financial market institutions and knowledge about them, differences in socioeconomic characteristics, the utility effects of asset conservation, how individuals perceive and quantify their longevity risk exposure and the existence of an efficient and affordable longevity insurance market [15].

In this chapter, we discuss and empirically investigate the welfare enhancing characteristics of alternative annuities (e.g., participating longevity-linked life annuities) and programmed withdrawal decumulation strategies, including simple decision rule methods and actuarial methods. Maximising annuity income is one important issue for many DC scheme members. Providing an efficient risk pooling mechanism that addresses the (individual) uncertainty of death through the provision of a lifetime annuity is one of the main mechanisms pension schemes are considered to redistribute income in a welfare-enhancing manner. Without such an instrument, individuals risk outliving their accumulated (financial, housing, pension) wealth or leaving unintended bequests to his/her dependants. Traditional (fixed, inflation-indexed) life annuities are a key instrument in mandated Defined Benefit (DB) pension schemes, in financial (FDC) and non-financial Notional Defined Contribution (NDC) schemes and in private pensions provided by insurance companies.

Yet, contrary to standard Modigliani life-cycle model of savings and consumption prediction, the voluntary market purchase of retirement annuities is in most countries very limited and decreasing and the actual saving/dissaving behaviour after retirement is often at odds with economic theory [16]. Several demand side (e.g., perceived poor value-for-money, the existence of annuity alternatives, bequest motives, behavioural and informational limitations, uncertainty regarding 
retirement income, shocks that prevent accumulation (e.g., unemployment spells and scarring effects ${ }^{1}$ ), precautionary behaviour to face major family shocks) and supply-side (e.g., the regulatory burden of annuity providers, with onerous capital requirements for unhedgeable risks (e.g., longevity risk) within Solvency II, nearly zero or negative interest rate environment and significant interest rate risk exposure and lack of solutions to hedge against (see, e.g., [18]), long-term financial risk, the cost of loss control and loss financing longevity risk management solutions, e.g., pension buy-ins, pension buy-outs, longevity bonds, longevity swaps, q-forwards, S-forwards, longevity options, limited reinsurance capacity to absorb massive exposure-to-risk and reduced risk appetite) arguments have been put forward to explain this "annuity puzzle", i.e., to explain why the level of annuitization by individuals is much smaller than economic theory would suggest. This has increased the attention towards new contract structures involving financial and longevity risk sharing mechanisms between the annuity provider and annuitants, and increased recommendations towards the use of deferred annuities, that reduce the cost of guarantees and potentially augment their attractiveness to policyholders.

Common drawdown rules are typically derived from subjective judgements, rules of thumb and simple assumptions, for instance, concerning the duration of the payout phase. Simple drawdown rules like the $1 / e_{x}$ involve splitting the pension pot into equal portions according to a fixed estimate of the life expectancy at age $x, e_{x}$, and disbursing one portion out to the retiree annually. The remaining funds are invested in financial assets to ensure a stable income flow. Other rules like the " $4 \%$ rule" target to maintain the real value of the income flow while also maintaining an account balance that keeps income flowing through retirement. Experts often name this withdrawal rate a safe withdrawal rate (SWR) as the withdrawals will consist primarily of interest and dividends but empirical studies confirm that the rule is suboptimal and inefficient.

Instead of using simple heuristic rules of thumb, an alternative approach to decumulation is to explicitly model consumers' behaviour and objectives though an objective function based on utility theory or cumulative prospect theory. The objective function should account for preferences towards consumption level, habits and smoothness, time, bequest, investment and longevity risks, health status, and other characteristics. The value of the objective function is controlled by decision variables like the consumption rate or the asset allocation between alternative asset classes including annuity-type structures. Retirement income outcomes can be measured in many ways including absolute dollar amounts, income replacement rates, or as a comparison to benchmark living standards. Several different utility functions have been proposed in the academic literature to investigate decumulation strategies and the optimality of dynamic, integrated consumption, and investment decision problems. To compare the range of possible retirement outcomes from competing decumulation designs, we provide some numerical results on optimal consumption and investment strategies using Monte-Carlo simulation methods and a stochastic mortality and investment risk framework to model biometric and financial market risks. The remaining of this chapter is organised as follows. In Section 2, we analyse the pensioner's retirement wallet portfolio composition. Section 3 highlights the key risk sources during the payout phase of pensions and the menu of decumulation options available at retirement. Section 4 explains the contact structure and valuation of innovative participating longevity-linked life annuity contracts. Section 5 empirically investigates the welfare enhancing

\footnotetext{
${ }^{1}$ See, e.g., [17] and references therein.
} 
characteristics of alternative pension decumulation strategies using Monte-Carlo simulation methods. Section 6 concludes.

\section{The retirement portfolio}

The retirement wallet portfolio of pensioners potentially comprises public and private pensions (state, linked to an employment relationship or occupational, based on contracts between individuals and private pension or insurance life annuity providers), private savings (dividends, coupon payments, cash withdrawals), housing wealth, continued labour income, insurance, (narrow or extended) family, and social institutions (Figure 1).

Public pension schemes (DB, DC, funded, or unfunded) typically provide a basic retirement income, with different layers of pension generosity across countries depending on the pension system structure and economic and financial system development. Private pension plans financed through pension funds, pension insurance contracts, book reserves, and bank or investment companies managed funds are becoming more widespread, but there are still enormous differences in the coverage and significance of private pension provisions across jurisdictions even after accounting for the size of the population or domestic economy. ${ }^{2}$ However, most DC scheme members have not contributed enough to receive even a modest income stream in retirement. For the contrary, building up housing wealth through homeownership and mortgage repayment is by far the main way European households set aside for old age [19]. In the Euro area countries, the household's wealth (excluding pension wealth) is primarily ( $82.2 \%$ of total assets) held in the form of real assets, the largest component being the household main residence (HMR), representing $60.2 \%$ of total real assets, with only $17.8 \%$ in the form of financial

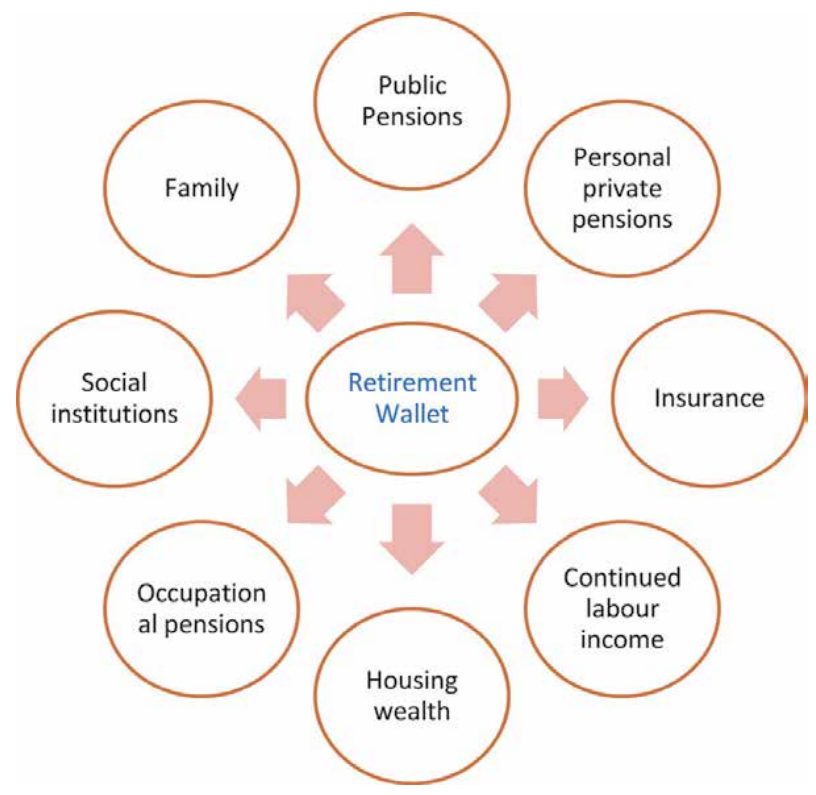

Figure 1.

Funding for longer lives: the retirement wallet. Source: Author's elaboration based on [6]. ${ }^{2}$ For example, pension funds held assets worth less than 1\% of GDP in France or Greece while they held
$171 \%$ of GDP in the Netherlands, $150.8 \%$ in Iceland or $132.6 \%$ in Australia. 


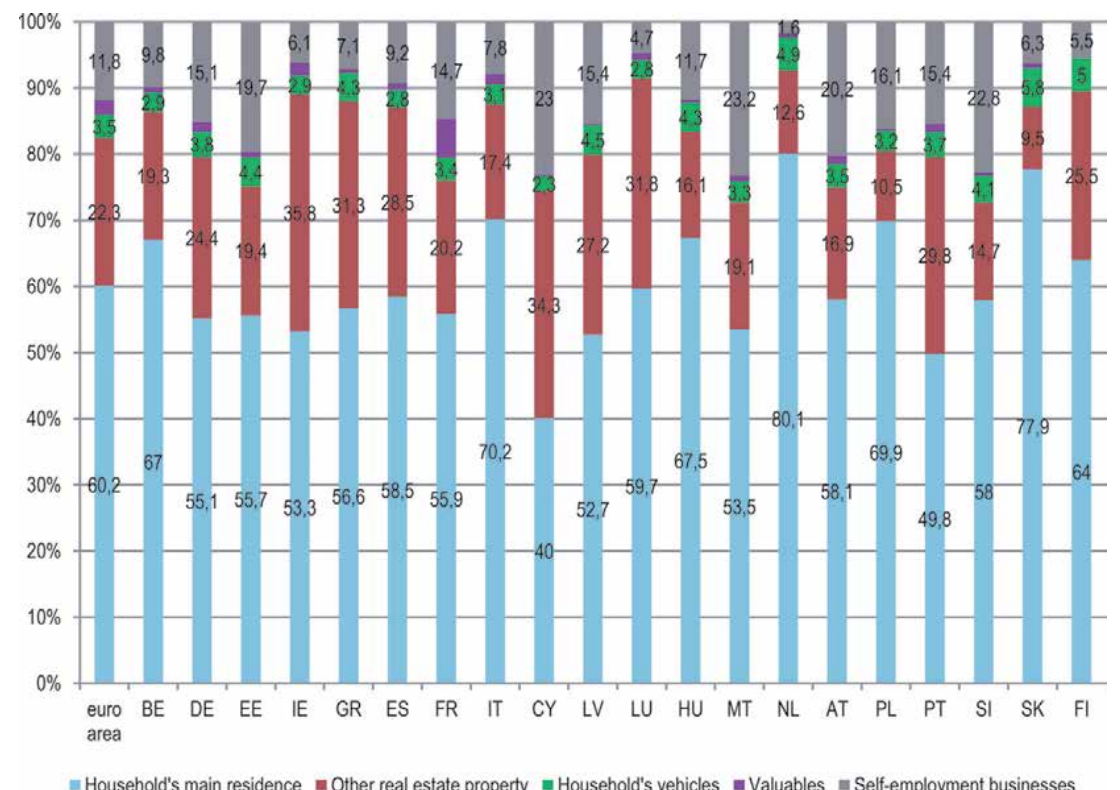

Figure 2.

Decomposition of real assets by asset category, euro area. Source: Own composition based on household finance and consumption survey, 2nd wave [19]. Notes: Shares of real assets types on total real assets by euro-area country. The HFCS classifies real assets into five categories: The HMR, other real estate property, vehicles, valuables (valuable jewellery, antiques, or art), and self-employment businesses.

assets (Figure 2). In the EU, roughly $70 \%$ of Europeans live in owner-occupied accommodation, ownership is higher in poorer countries and the proportion of homeowners by age band has been steadily increasing with each successive generation. Empirical evidence also shows that homeowners are generally wealthier than their non-home owning counterparts, and this conclusion is valid across the income or net wealth distribution and across countries [20].

If retirees wish to assume responsibility for their welfare needs at retirement, private pensions and private homeownership are the two main assets available to finance them. The two options involve long-term saving and investment decisions over the life cycle, both are motivated by potentially competing and conflicting objectives, but they tend to deliver different outcomes and options in the decumulation phase of pensions [6]. Home homeownership provides a stream of housing services starting at time of house acquisition and represents wealth which could be cashed in later in life, if needed. The asset serves both consumption and investment functions, which are assessed differently by households according to their personal preferences, for example, bequest motives. The main difficulty is currently managing and accessing housing wealth in an efficient way to supplement retirement income. In theory, there is a catalogue of Equity Release Mechanisms (ERS) available to individuals, including contract structures which allow individuals to sell and continue to live in their home (e.g., home reversion schemes), others that involve selling and moving (e.g., rent, downsizing, moving to a third-party home), and in situ mortgage ERS, for instance, reverse mortgages (Figure 3). Other design features include the time of equity release, the ownership of the property, or the amount of equity that can be potentially released. ${ }^{3}$

The family will continue to play an important role in the retirement wallet portfolio in most countries and regions, particularly in the form of services and

\footnotetext{
${ }^{3}$ See [20] for a detailed analysis of ERS schemes.
} 


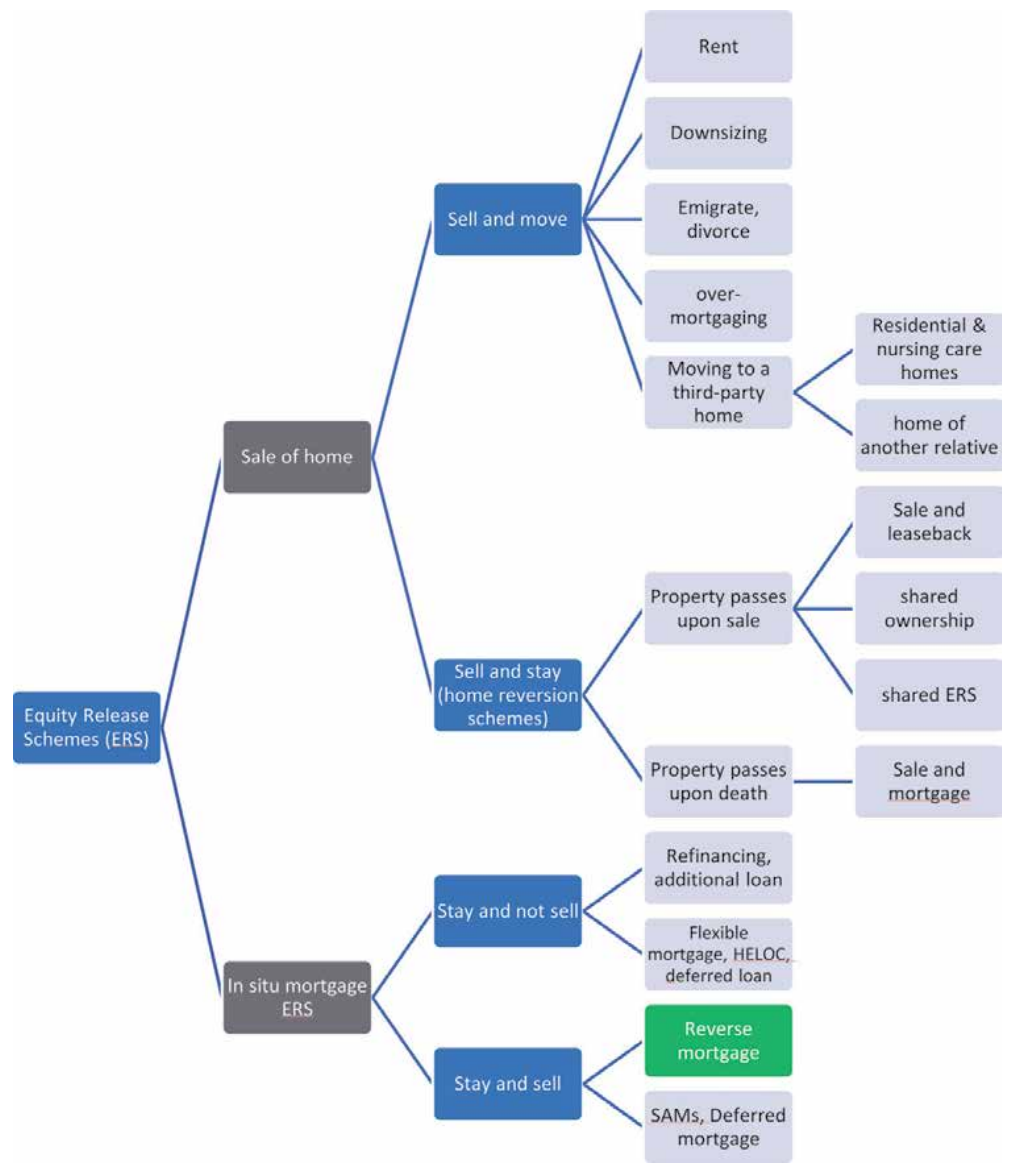

Figure 3.

Typology of equity release mechanisms. Source: Own composition based on [20-23] with author's additions.

care, although family support is likely to be less relevant in the future due to smaller family sizes, fewer children to provide care, changing family composition, higher children's mobility, and increasing female labour market participation. Support from local/municipal social institutions (e.g., retirement communities) also has an important role in retirement, especially for low-income groups. Insurance mechanisms must play an increasing role in the retirement wallet portfolio of retirees since some of the most important risks individuals face during retirement (e.g., longevity risk, health-care risk, long-term care risk, investment risk, inflation risk) are insurable risks and traditional and innovative solutions have been developing to address them in a cost-efficient manner [15]. Contrary to traditional models of labour supply, empirical evidence suggests that the share of labour income from continued work after statutory retirement age is increasing and the trend is persistent.

The build-up, management, and decumulation of the retirement wallet portfolio are different between individuals and are not guaranteed to be optimal as predicted by the lifecycle hypothesis. This is because uncertainty regarding retirement income, the existence shocks that prevent accumulation (e.g., unemployment spells and scarring effects $)^{4}$, precautionary saving preventing major family shocks (e.g., death of a spouse, divorce), uninsured future health care and long-term expenditures, intended bequests, behavioural and cultural biases, outdated social norms and

\footnotetext{
${ }^{4}$ See, e.g., [17] and references therein.
} 
psychological barriers, mental-accounting, the design and implementation of mandated earnings-related retirement schemes across countries including minimum income and service guarantees, pensions taxation regimes that penalise accumulating or decumulation, low risk appetite and financial literacy, and the heterogeneity in longevity by income levels $[5,16]$.

\section{The decumulation menu of pensions}

The decumulation or payout phase of pensions is the process of converting the retirement portfolio into a regular flow of income and services. Decumulation requires individuals to decide upon a retirement strategy, comprising a longevity insurance strategy determining the provisions taken by individuals to protect against longevity risk, that is, to guarantee they do not outlive their retirement portfolio, a withdrawal strategy, stipulating how much to withdraw from the retirement pot to finance regular consumption expenditures, an investment strategy determining how to maximise the portfolio's return considering one's risk profile ${ }^{5}$, and efficient and effective administration.

The key risk sources during decumulation include individual and aggregate longevity, investment, health, liquidity, inflation, retirement timing, bequest, annuitization, life shocks, taxation, political and regulatory interventions, market conduct, and credit risk (Table 1). Individuals can manage these risks through, for instance, intra-generational risk pooling mechanisms (e.g., insurance), intergenerational risk sharing vehicles (e.g., pension schemes), proper hedging instruments, risk mitigation and diversification strategies, default investment options, financial education, and effective regulation.

Typical retirement income goals include: (i) maximising the expected retirement income and consumption over one's lifetime; (ii) consumption smoothing, (iii) generate a lifetime retirement income that cannot be outlived, (iv) preserving the ability to bequest unused wealth, (v) liquidity concerns in case of unforeseen expenses (e.g., long-term care), (vi) protecting against common financial and biometric risks (e.g., longevity, inflation, investment, life events, fraud), (vii) preserving the purchasing power of income, (viii) preserving the chance to profit from upward trends in financial markets, and (ix) keeping the investment strategy simple. The main options available for decumulating retirement assets accumulated in DC pension plans include lump sum payments, programmed or phased withdrawals, life annuities, and hybrid solutions.

The possibility of taking accumulated financial savings as a cash lump sum is typically dependent both on the contractual arrangements defined by the pension plan and the tax rules in force in a particular jurisdiction. Lump sum payments offer retirees full flexibility in the use of accumulated savings, including spending on leisure activities, passing on part of their retirement pot to children or other family members, investing in new or additional property, paying off a mortgage on a house or other debts, continuing to pursue an investment strategy, and the ability to "selfannuitize" at a time and on a basis that best suits their financial needs, but also embodies important shortcomings, particularly the lack of protection against (individual and aggregate) longevity risk, and against investment, credit, and inflation risks [7].

\footnotetext{
${ }^{5}$ Note that the benchmark for assessing the investment performance is not in this case in terms of an asset benchmark but in terms of a given liability cash flow stream (consumption expenditures), i.e., this is a liability-driven investing (LDI) strategy (see, e.g., [18, 24-27]).
} 
Addressing the Pension Decumulation Phase of Employee Retirement Planning

DOI: http://dx.doi.org/10.5772/intechopen.90807

\begin{tabular}{|c|c|}
\hline Risk & Definition \\
\hline Individual longevity & $\begin{array}{l}\text { Risk of outliving the retirement pot or experiencing a substantial reduction in } \\
\text { retirement income }\end{array}$ \\
\hline Aggregate longevity & $\begin{array}{l}\text { Risk that overall population lives longer than anticipated forcing, e.g., a } \\
\text { reduction in public pension benefits }\end{array}$ \\
\hline Investment & $\begin{array}{l}\text { The risk that portfolio investment performance mismatches the desired pattern } \\
\text { of consumption in retirement }\end{array}$ \\
\hline Inflation & $\begin{array}{l}\text { The risk that a generalised rise in prices erodes the purchasing power of } \\
\text { pensions benefits and other retirement income }\end{array}$ \\
\hline Health/dependency & $\begin{array}{l}\text { Risk that a deteriorating health condition significantly increases health-care o } \\
\text { long-term care expenditures }\end{array}$ \\
\hline Liquidity & Risk arising from the lack of marketability of retirement assets \\
\hline $\begin{array}{l}\text { Retirement timing } \\
\text { risk }\end{array}$ & $\begin{array}{l}\text { Uncertainty about when the scheme member will retire from labour market } \\
\text { and/or begin to make withdrawals }\end{array}$ \\
\hline Bequest & $\begin{array}{l}\text { Most parents have an altruistic approach to life and care about their closest } \\
\text { relatives, and try to leave them the household's main residence, cash, or her } \\
\text { financial and real assets }\end{array}$ \\
\hline Annuitization & $\begin{array}{l}\text { Mandatory annuitization may take place at a point where interest rates are } \\
\text { lower than anticipated }\end{array}$ \\
\hline $\begin{array}{l}\text { Political and } \\
\text { regulatory }\end{array}$ & $\begin{array}{l}\text { The risk that either public of private pension system providers may be forced } \\
\text { to reduce their pension payments, because pension systems are financially } \\
\text { unsustainable or as a result of a political decision and the risk that regulations } \\
\text { change in an adverse way }\end{array}$ \\
\hline Taxes & $\begin{array}{l}\text { Risk that a variation in the regulatory or tax environment will reduce the } \\
\text { disposable retirement income, e.g., an increase in income tax rates or } \\
\text { deductions, an increase in VAT taxes, an increase in capital market taxes }\end{array}$ \\
\hline Life events & Divorce, death of spouse/partner, etc \\
\hline Behavioural & $\begin{array}{l}\text { Risk that pensioners behave in a way that is not considered to be rational, } \\
\text { incapacity to make an 'informed choice' due to insufficient financial literacy } \\
\text { and understanding of risks }\end{array}$ \\
\hline $\begin{array}{l}\text { Market conduct and } \\
\text { credit risk }\end{array}$ & $\begin{array}{l}\text { The risk that financial and non-financial service providers act in a way that } \\
\text { disadvantages retirees and credit risk referring to the events after which } \\
\text { companies or individuals will be unable to make the required payments on } \\
\text { their debt or contract obligations }\end{array}$ \\
\hline \multicolumn{2}{|c|}{ Source: Author's elaboration based on $[6,7,28]$. } \\
\hline
\end{tabular}

Table 1.

Key risk sources during the payout phase of pensions.

Programmed withdrawal arrangements allow retirees to cash in periodically from their retirement portfolio to cover necessary expenses, allowing individuals to preserve control and ownership over their assets, to decide upon the desired investment strategy, but do encompass biometrical risk-pooling that protects, for example, against longevity risk. The regular income flows may be the result of an explicit withdrawal rule or plan (e.g., the so-called $4 \%$ sustainable withdrawal rule, a fraction of the remaining life expectancy at the retirement age, possibly with lower and upper bounds, a constant amount) or simply be the result of discretionary actions. ${ }^{6}$

\footnotetext{
${ }^{6}$ Although self-managed products are available, normally retirement withdrawal products are delegated management retirement products under which the account management activities are allocated to the asset management company.
} 
The fixed percentage, the constant (inflation-adjusted), and the floorand-ceiling withdrawals rules were introduced by $[29,30]$. The first spending rule considers fixed-percentage withdrawals (users spend a constant percentage of their assets in each year of retirement) and the second one considers an annual adjustment for inflation. The third method considers establishes a floor and a ceiling to cash withdrawals. According to [31, 32], this strategy allows greater spending when markets do well and spending reductions when markets do poorly. The target Percentage Adjustment rule was introduced in [33] and defines whether spending adjusts for inflation given a fixed-return assumption and a 45-year time horizon.

Programmed withdrawal has some advantages compared with annuity purchase (e.g., higher liquidity and flexibility to respond to unexpected consumption expenditures, retaining control over retirement assets, potentially higher payouts due to enhanced investment returns, possibility to allocate assets to inflationlinked investments, compatibility with the bequest motive, death benefit options), but also several drawbacks, particularly the lack of protection against longevity risk, no mortality cross subsidy, and significant exposure to investment risk [6].

The classical payout option for generating a predictable income stream in retirement is a life annuity. Annuity products offer protection against individual and aggregate longevity risk, a mortality cross subsidy from pooling risks but imply the loss of control over assets and no flexibility to address unexpected expenditures or the bequest motive. There are many types of annuities that can be differentiated, for instance, by the nature of payment, by the number of people covered, by the duration of payments, by the time that payouts commence, by the frequency of premium payments, by the distribution channel and types of options included, among other features (Figure 4). Recent developments in this area include participating longevity-linked life annuities in which annuitants share both investment

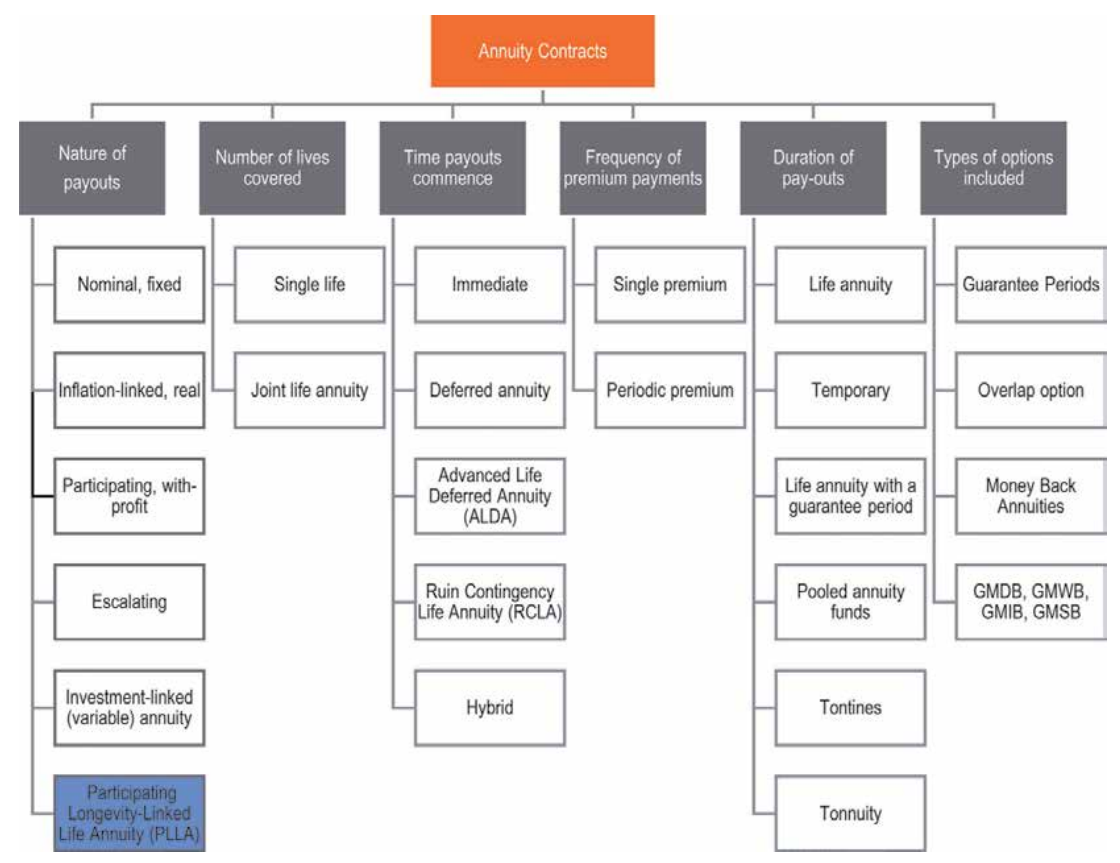

Figure 4 .

Types of life annuities. Source: Author's elaboration based on [6, 7]. 
and longevity risk but profit from risk-pooling [11, 12, 34], variable annuities ${ }^{7}$, modern Tontines [13], and Tonnuity [14].

According to [35-37], a deferred annuity is suitable for risk-averse individuals, because it insures against increases in annuity prices and provides a smooth income. The group self-annuitization scheme (GSA) proposed by [39, 40] was analysed in [38] where pool participants are insured against individual longevity risk and share systematic mortality and longevity risks. They put forward that the GSA can outperform inflation-linked annuities when there are loadings. When individuals have a bequest motive, portfolios with phased withdrawals improve individuals' welfare. Their results follow previous literature which suggests that individuals should not fully annuitize their wealth but hold an equity portfolio and match their consumption expenditures with regular cash withdrawals.

\section{Sharing investment and longevity risk: participating longevity-linked life annuities}

Contrary to standard life-cycle theory, the voluntary market purchase of retirement annuities is very limited and decreasing in most countries and the actual saving/dissaving behaviour after retirement is often at odds with economic theory [16]. A number of demand side (e.g., perceived poor value-for-money, the existence of annuity alternatives, bequest motives, behavioural and informational limitations) and supply-side (e.g., the regulatory burden of annuity providers) with onerous capital requirements for unhedgeable risks (e.g., longevity risk) within Solvency II, nearly zero interest rate environment and significant interest rate risk exposure, long-term financial risk, the cost of loss control and loss financing longevity risk management solutions, limited reinsurance capacity to absorb massive exposure-to-risk) arguments have been put forward to explain this "annuity puzzle", that is, to explain why the level of annuitization by individuals is much smaller than economic theory would suggest $[6,41,42]$. Several index-type and indemnity-type mechanisms have been proposed in the literature to directly or indirectly share financial and longevity risks between annuity providers and individuals $[10,11,43]$.

Participating longevity-linked life annuities (PLLAs) are life insurance contracts in which benefits are updated periodically based on the dynamics of both a longevity index, defined as the ratio between the expected survival probability and the survival rate observed in a reference population, and of an interest rate adjustment factor, defined as the ratio between observed and guaranteed financial returns

\footnotetext{
7 Variable annuities can adopt different forms. Annuity benefits can rise (or fall) at a prescribed fixed nominal rate that escalates with the age of the annuitant (escalating annuity); they can be indexed to inflation, thus providing a guaranteed income in real terms (inflation linked or real annuity); they can be linked to observed survival probability (longevity-linked life annuity); they can depend on the insurance company's surplus (participating or with profit annuity); or even reflect the performance of an underlying investment portfolio, usually represented by a family of mutual funds (investment-linked or variable annuity). In some annuities, pay-outs can also participate in mortality risk. The most common guarantees embedded in variable annuities are: (i) guaranteed minimum death benefit (GMDB); (ii) guaranteed minimum income benefit (GMIB); (iii) guaranteed minimum withdrawal benefit (GMWB); (iv) guaranteed lifetime withdrawal benefit (GLWB); (v) guaranteed minimum accumulation benefit (GMAB).
} 
$[10,11] . .^{8}$ In this section, we briefly describe the benefit structure and risk sharing design of immediate PLLAs. We then introduce the valuation setup via embedded longevity option decomposition.

Consider an index-type participating longevity-linked life annuity (PLLA) along the lines proposed by $[11,12]$. Under this arrangement, the annuity benefit is periodically updated according to both the observed survival experience of a reference pool and the investment performance of the financial assets backing the contract. Without loss of generality, let us assume a single cohort product in which annuitants contribute equal amounts into the annuity fund and, in return, receive equal annuity benefit payments $b_{t}$ at time $t$. Under this contract, the annual benefit at some future date $t_{0}+k, b_{t_{0}+k}$, will depart from the initial benefit, $b_{t_{0}}$, according to the dynamics of both a longevity $I_{t_{0}+k}$ and an interest rate adjustment (IRA) $R_{t_{0}+k}$ factors as follows:

$$
b_{t_{0}+k}=b_{t_{0}} \times I_{t_{0}+k} \times R_{t_{0}+k}, \quad k=1, \ldots, \omega-x
$$

where $I_{t_{0}+k}$ is a ratio between the expected survival probability and the survival rate observed in a reference population, defined by

$$
I_{t_{0}+k}=\frac{{ }_{k} p_{x_{0}}^{\left[F_{0}\right]}\left(t_{0}\right)}{{ }_{k} p_{x_{0}}^{\left[F_{k}\right]}\left(t_{k}\right)}=\prod_{j=0}^{k-1} \frac{p_{x_{0}+j}^{\left[F_{0}\right]}\left(t_{0}+j\right)}{p_{x_{0}+j}^{\left[F_{k}\right]}\left(t_{0}+j\right)}
$$

with

$$
{ }_{k} p_{x_{0}+j}^{\left[F_{0}\right]}\left(t_{0}+j\right)=\prod_{j=0}^{k-1}\left[1-q_{x_{0}+j}\left(t_{0}+j\right)\right]
$$

denoting the k-year survival probability of some reference population cohort aged $x_{0}$ at time $t_{0}$ (computed at contract inception on a market or national population life table) and ${ }_{k} p_{x_{0}}^{\left[F_{k}\right]}\left(t_{k}\right)$ is the corresponding k-year survival probability observed at time and the highest attainable age. In Eq. (3), $q_{x_{0}+j}\left(t_{0}+j\right)$ is the 1 -year death probability of an individual aged $x_{0}+j$ at time $t_{0}+j$. The IRA factor $R_{t_{0}+k}$ is defined by

$$
R_{t_{0}+k}=\frac{\prod_{j=0}^{k-1}\left(1+R_{t}\right)}{\left(1+i_{t_{0}}\right)^{k}}
$$

where $R_{t}$ denotes the observed net investment return in year $t$ and $i_{t 0}$ is the (generally non-negative) guaranteed minimum interest rate set at time 0 .

If investment and mortality improvements are as expected, the arrangement resembles a classical nominal fixed life annuity. If $R_{t}=i_{t 0}$ and observed longevity improvements are higher (lower) than predicted, that is, $I_{t_{0}+k}<1\left(I_{t_{0}+k}>1\right) \forall \mathrm{k}$, annuity payments will decline (increase) along with the dynamics of $I_{t_{0}+k}$. If mortality improvements are as expected and investments perform above the guaranteed interest rate, the extra return is returned to participants in the form of a higher benefit payment. This risk-sharing nature of this contract contrasts with classical

\footnotetext{
${ }^{8}$ A related approach is found in [34] in which annuity payments are updated only if observed survivorship rates exceed a given threshold.
} 
fixed annuities in which all risks (financial and biometric) are transferred to the annuity provider. Benefit volatility may be mitigated by introducing bounds to the longevity and IRA adjustment factors (or to the benefit amount).

The valuation of a PLLA at time $t_{0}$ can be obtained via longevity option decomposition (see [11] for details), that is, by decomposing the PLLA into a long position in a fixed annuity $a_{x_{0}}^{\left[F_{0}\right]}\left(t_{0}\right)$ and a short position in an embedded European-style longevity floor $L^{F_{0}}\left(t_{0}\right)$ with underlying $I_{t_{0}+k}$, constant strike equal to one unit of currency and maturity $\omega-x_{0}$,

$$
a_{x_{0}}^{P L L A}\left(t_{0}\right)=a_{x_{0}}^{\left[F_{0}\right]}\left(t_{0}\right)-L^{F}\left(t_{0}\right)
$$

with

$$
L^{F}\left(t_{0}\right)=\sum_{k=1}^{\omega-x_{0}} E^{Q}\left(B(0, k) \times{ }_{k} p_{x_{0}}^{\left[F_{0}\right]}\left(t_{0}\right) \times\left(1-I_{t_{0}+k}\right)^{+} \mid F\right)
$$

where $B(t, T)$ is the interest rate discount factor, $a^{+}:=\max (a, 0)$ and, without loss of generality, we consider an immediate PLLA contract with initial benefit $b_{t_{0}}=1$ and a scenario in which observed longevity improvements are higher than predicted and investment performance matches the guaranteed interest rate.

\section{On the welfare of pension decumulation strategies}

In this section, we empirically investigate the welfare enhancing characteristics of alternative pension decumulation strategies. Specifically, we test eight alternative strategies tested:

i. A fixed withdrawal rule based on life expectancy observed at age in the retirement year $t_{0}$, that is, a $1 / e_{x, t_{0}}$ rule

ii. A fixed withdrawal rule based on the life annuity factor estimated at age in the retirement year $t_{0}, 1 / a_{x, t_{0}}$, with no annuitization

iii. A withdrawal rule based on life expectancy observed at age $x$ in year $t, 1 / e_{x, t}$

iv. The " $4 \%$ " SWR rule

v. Buying a PLLA at retirement age

vi. Buying a classical single premium nominal life annuity (SPLA) at retirement age

vii. Investing $80 \%$ of the initial wealth in the " $4 \%$ " SWR rule and the remaining $20 \%$ in a ALDA

viii.Buying an Inflation-Protected Annuity (IPA) at retirement age

The welfare analysis considers a time-separable utility function including lifetime consumption and bequest motives [44]. We assume individuals want to maximise the expected present value of utility derived from consumption through their remaining lifetime, 


$$
U_{t}=\max _{c_{1}, c_{1}, \ldots, c_{T}} E_{t}\left[\sum_{k=1}^{\omega-x_{0}} \beta^{t}\left\{{ }_{k} p_{x_{0}}^{\left[F_{0}\right]} \mathcal{u}\left(c_{t}\right)+_{t-1} q_{x_{0}}^{\left[F_{0}\right]} \gamma\left(W_{t}\right)\right\}\right]
$$

with

$$
u\left(c_{t}\right)=\frac{c_{t}^{1-\rho}}{1-\rho}, \quad c_{t} \geq 0
$$

and

$$
\gamma\left(W_{t}\right)=\left(\frac{\varphi}{1-\varphi}\right) \frac{\rho\left(\frac{\varphi}{1-\varphi} c_{b}+W_{t}\right)^{1-\rho}}{1-\rho}, W_{t} \geq 0
$$

where $\beta$ is the subjective utility discount factor, $\rho>0$ the level of risk aversion, $c_{b}$ measures the degree to which bequests are considered as luxury goods, $\varphi[0,1)$ measures the strength of the member's bequest motive when bequest has kicked in (i.e., when $W_{t}>c_{b}$ ).

The utility function expresses the preferences of individuals by assigning higher values on favourable outcomes (higher consumption and bequest) while marking down poor outcomes such as a consistently lower level of retirement income. The utility function separately considers the risk aversion over consumption and bequest, allowing for subjective adjustments to how the individuals value different retirement outcomes. The dynamics of wealth is

$$
W_{t+1}=\left(W_{t}-c_{t}+P_{t}\right)\left(1+R_{t+1}\right),
$$

where $R_{t+1}$ is the stochastic (post-tax) rate of return.

To compare the performance of alternative decumulation strategies, we compute a utility score, $S_{0}$, defined as the constant level of income which delivers an equivalent level of expected utility to that delivered by each strategy,

$$
S_{0}=\left[U_{0} \times \frac{1-\rho}{\left(\sum_{k=1}^{\omega-x_{0}} \beta^{t}\left\{k p_{x_{0}}^{\left[F_{0}\right]}+{ }_{t-1} q_{x_{0}}^{\left[F_{0}\right]}+\left(\frac{\varphi}{1-\varphi}\right)\right\}\right)}\right]^{\frac{1}{1-\rho}},
$$

The valuation framework comprises a risk-neutral, frictionless and continuous financial market in which the annuity provider invests the insurance premium in a portfolio of dividend-paying stocks (30\%) and coupon bonds (70\%), and a risk-free interest rate. We assume the yield curve dynamics is well captured by a two-factor equilibrium model [45] and the stock market index follows a standard geometric Brownian motion diffusion process.

To account for the longevity risk premium in pricing the contracts, we compute cohort-specific risk-adjusted survival probabilities by using a risk-neutral simulation approach assuming the dynamics of mortality rates is well represented by the log bilinear Lee-Carter model under a Poisson setting, with time trend parameter modelled using a general ARIMA $(\mathrm{p}, \mathrm{d}, \mathrm{q})$ model and risk neutral distribution of the innovations obtained using the Wang transform. The results are generated through 10,000 independent sample paths for both the survival probability of a cohort aged $x$ in at time 0 and the portfolio returns. We calibrate the models to historical (monthly) data on US 3-month and 10-year maturity bond yields from January 1, 2010 to September 1, 2019 and to US mortality data from 1960 to 2016 obtained from the human mortality database [46]. The baseline parameters are given in Table 2. 
Figure 5 plots the dynamics of consumption over time for the eight strategies tested. Except for level fixed SPIA annuities that payoff a constant nominal benefit for life, all other strategies experience some benefit volatility and different trends. Inflation-protected annuities guarantee constant real benefits, which means nominal steadily increase with inflation over time. The $4 \%$ SWR rule generates increasing consumption over time but only up to some point, when the portfolio value is exhausted and consumption levels must be reduced. When combined with the acquisition of an ALDA annuity, the 4\% delivers increasing and sustainable

\begin{tabular}{lcc}
\hline Parameter & Value & Notes \\
\hline Subjective utility discount factor: $\beta$ & 0.975 & \\
\hline Risk aversion coefficient: $\rho$ & 5 & \\
\hline Strength of bequest motive: $\varphi$ & 0.83 & $\times 10^{3}$ USD \\
\hline Bequests as luxury goods level: $c_{b}$ & 25.8 & $\times 10^{3}$ USD \\
\hline Initial wealth (1000 s): $W_{0}$ & 210 & \\
\hline Tax rate: $s$ & $20 \%$ & years \\
\hline ALDA deferment period: $k$ & 20 & \\
\hline Pension benefits: $P_{t}$ & 0 & \\
\hline Life annuity loading & $10 \%$ & years \\
\hline PLLA bounds & $(80 \% ; 120 \%)$ & \\
\hline Number of simulations & 1000 & $\times 10^{3}$ USD \\
\hline Investment horizon & 35 & \\
\hline Guaranteed annuity interest rate (GIR) & $1 \%$ & 6 \\
\hline Minimum consumption level & & \\
\hline Source: Author's elaboration. & & \\
\hline
\end{tabular}

Table 2.

Baseline parameters.

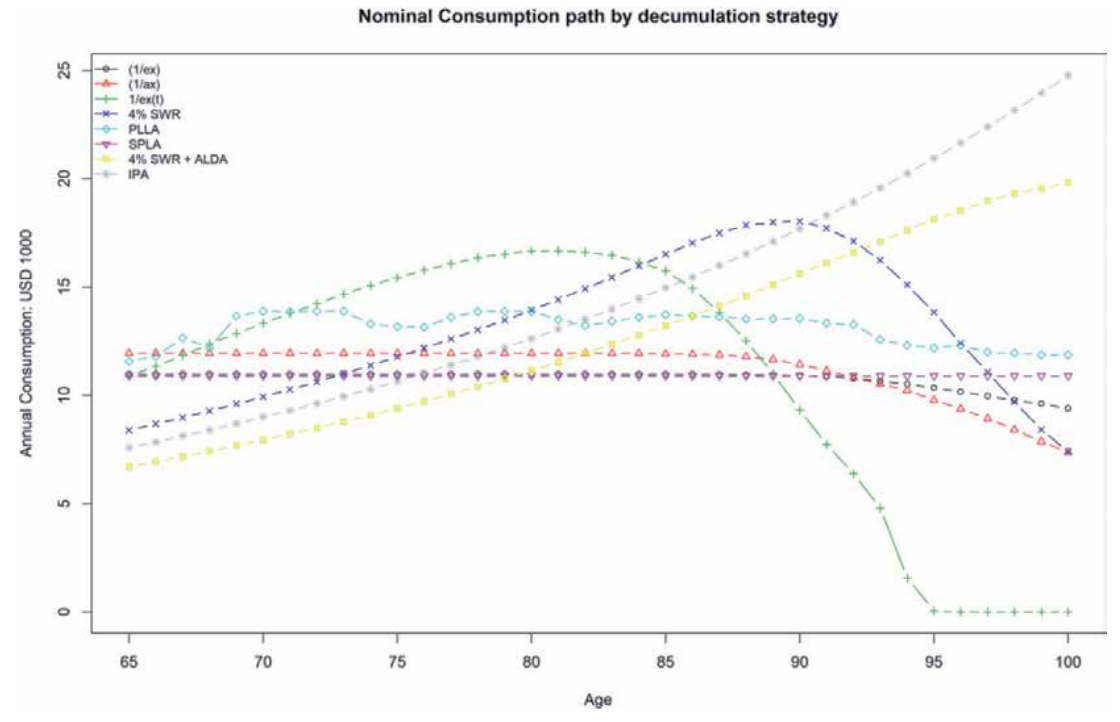

Figure 5 .

Dynamics of consumption level by decumulation strategy. Source: Author's elaboration. 


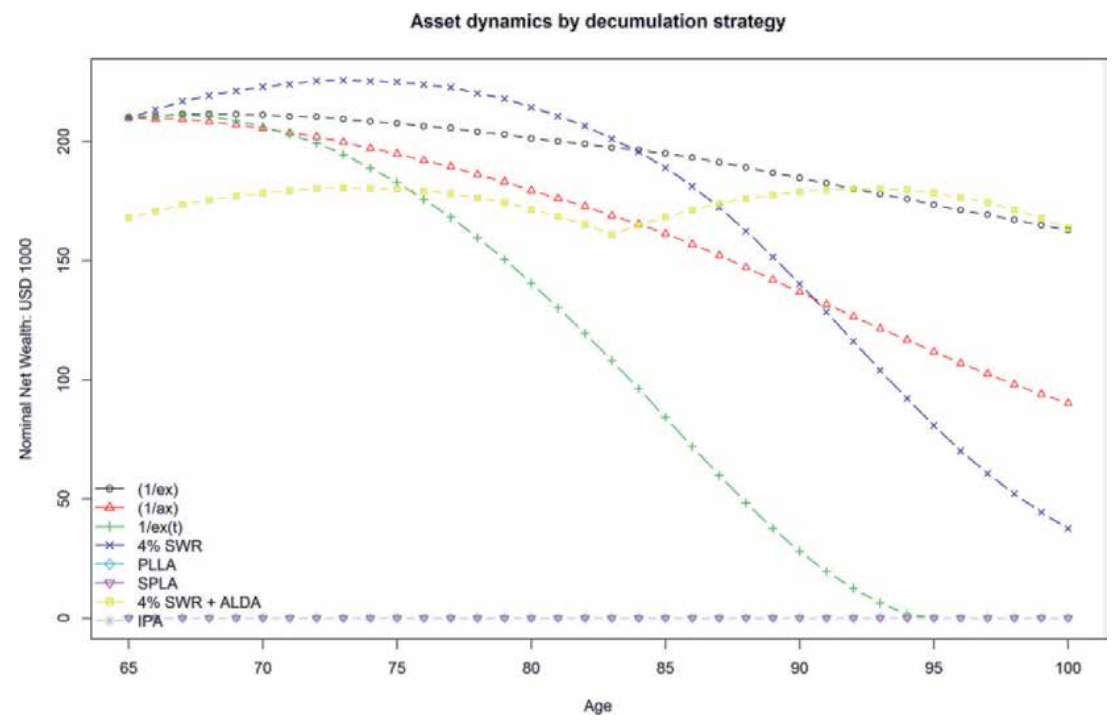

Figure 6.

Wealth dynamics by decumulation strategy. Source: Author's elaboration.

consumption levels and longevity insurance. The dynamic life expectancy strategy generates consumption levels that cannot be sustained over time, quickly converging towards deprivation and personal bankruptcy. The PLLA structure with $20 \%$ maximum benefit volatility pays higher benefits compared with a classic SPIA annuity or self-annuitization strategies and offers longevity insurance for life, but at the expense of additional benefit volatility.

Figure 6 plots the wealth dynamics by decumulation strategy over a 35-year period. For strategies involving full annuitization, the remaining wealth is, by definition, zero since all assets are used to pay for the insurance premium. For the remaining, the dynamics of the asset portfolio depends on regular consumption levels and portfolio annual returns. We can observe that for all strategies the portfolio value reduces with time, in some cases until its complete exhaustion (e.g., $1 /$ ex, $t$ strategy).

We can observe also that the classical 4\% SWR rule is not sustainable for long planning horizons, contrary to the conservative static life expectancy strategy $1 / e x, 0$ that delivers significant bequest utility. When combined with advanced age longevity insurance, the strategy is likely to improve individuals' welfare when they have a bequest motive since additional portfolio value is preserved. Ceteris paribus, the higher the wealth level at death (if positive), the higher the utility from leaving values in the residual benefit. Individuals pursuing a self-annuitization strategy $1 / a x, t$ are also likely to guarantee an inheritance to their heirs.

Table 3 provides illustrative simulation-based welfare results for the decumulation strategies tested in this study in which individuals are exposed to market and longevity risk. The results include the mean consumption and wealth levels over the planning horizon and the asset balance at age 100, consumption volatility (standard deviation), expected utility computed using Eq. (7) and utility score values. ${ }^{9}$

We can observe that the decumulation strategy involving purchasing a participating longevity-linked annuity at retirement age provides the highest utility score,

\footnotetext{
9 Detailed results can be obtained from the author upon request.
} 
Addressing the Pension Decumulation Phase of Employee Retirement Planning DOI: http://dx.doi.org/10.5772/intechopen.90807

\begin{tabular}{lcccccccc}
\hline Metric & \multicolumn{7}{c}{ Strategy } \\
\hline & $\mathbf{1 / e x , 0}$ & $\mathbf{1 / a x e , 0}$ & $\mathbf{1 / e x , \mathbf { t }}$ & $\mathbf{4 \%}$ rule & PLLA & SPLA & $\mathbf{4 \%}+$ ALDA & IPA \\
\hline Mean $C_{t}$ & 9.38 & 8.77 & 6.98 & 9.06 & 12.53 & 10.90 & 14.57 & 22.24 \\
\hline Ct stdev & 2.43 & 4.13 & 7.19 & 8.23 & 1.30 & 0.00 & 6.80 & 11.92 \\
\hline Mean $W_{t}$ & 180,98 & 129.72 & 68.62 & 112.77 & 0.00 & 0.00 & 150.22 & 0.00 \\
\hline $\begin{array}{l}W_{t}(\text { age } \\
100)\end{array}$ & 162.70 & 90.18 & 0.00 & 37.54 & 0.00 & 0.00 & 163.54 & 0.00 \\
\hline$E\left(U_{t}\right)$ & -4.0 & $-263,7$ & -744.078 & -318.4 & -0.00012 & -0.00025 & -0.00071 & -0.00043 \\
\hline$S_{0}$ & 11.29 & 11.78 & 9.29 & 10.47 & 13.69 & 11.45 & 8.82 & 9.99 \\
\hline Source: Author's elaboration. Notes: Market price of longevity risk set by $\lambda=0.3$ (Wang Transform parameter). \\
\hline
\end{tabular}

Table 3.

Simulation-based welfare results: baseline scenario.

that is, the highest (certain equivalent) constant level of income (considering the trade-off against residual benefit) which delivers an equivalent level of expected utility. The self-annuitization decumulation strategy comes second in terms of utility score, followed by classical SPIA annuity purchase. The good performance of the PLLA strategy is explained essentially by the higher consumption levels it delivers in early retirement years which are less discounted (actuarily and intertemporally) by individuals since, by construction, the strategy offers no utility from bequest. The strategy provides longevity risk insurance and relatively low consumption volatility when compared with most alternatives.

\section{Conclusions}

In this chapter, we review and discuss the main pension decumulation options by explicitly modelling consumers' behaviour and objectives though an objective function based on utility theory accounting for consumption and bequest motives and different risk preferences. We conclude that purchasing a capped participating longevity-linked life annuity at retirement including embedded longevity and financial options that allow the annuity provider to periodically revise annuity payments if observed survivorship and portfolio outcomes deviate from expected (or guaranteed) values as contract initiation deliver superior welfare results when compared with classical annuitization and non-annuitization decumulation strategies. Contrary to standard fixed annuities in which the insurer bears all risk, PLLAs offer an efficient and transparent way of sharing biometric and financial market risks between annuity providers and policyholders. They are an interesting and promising product for the payout phase of pension schemes since the contract tackles some of the demand-and supply-side constraints that prevent individuals from annuitizing their retirement wealth and may contribute to help insurers writing new annuity policies. By linking the annuity benefit to the survival experience of a given underlying population and to the performance of the asset portfolio backing the contract PLLAs provide a direct mechanism to share financial and longevity risk and are an interesting alternative to manage systematic longevity risk in markets in which alternative risk management solutions (longevitylinked securities, reinsurance arrangements, capital allocation) are scarce and/or expensive. 


\section{Author details}

Jorge Miguel Ventura Bravo

NOVA IMS \& MagIC \& CEFAGE-UE \& Université Paris-Dauphine, Nova University of Lisbon, Lisbon, Portugal

*Address all correspondence to: jbravo@novaims.unl.pt

\section{IntechOpen}

(C) 2020 The Author(s). Licensee IntechOpen. This chapter is distributed under the terms of the Creative Commons Attribution License (http://creativecommons.org/licenses/ by/3.0), which permits unrestricted use, distribution, and reproduction in any medium, provided the original work is properly cited. (c) BY 


\section{References}

[1] Ayuso M, Bravo JM, Holzmann R. On the heterogeneity in longevity among socioeconomic groups: Scope, trends, and implications for earnings-related pension schemes. Global Journal of Human Social Sciences-Economics. 2017;17(1):31-57

[2] Ayuso M, Bravo JM, Holzmann R. Addressing longevity heterogeneity in pension scheme design. Journal of Finance and Economics. 2017;6(1): $1-21$

[3] Ayuso M, Bravo JM, Holzmann R. Getting life expectancy estimates right for pension policy period versus cohort approach. Journal of Pension Economics and Finance. 2019. Accepted, (in press)

[4] Bravo JM, Ayuso M, Holzmann R. Palmer E. Addressing the life expectancy gap in pension policy. 2019. Preprint submitted for publication

[5] Bravo JM. Taxation of pensions in Portugal: A semi-dual income tax system. CESifo DICE Report-Journal for Institutional Comparisons. 2016; 14(1):14-23

[6] Bravo JM. Funding for longer lives: Retirement wallet and risk-sharing annuities. EKONOMIAZ Basque Economic Review. 2019;96(II-2019): 268-291

[7] Bravo JM, Holzmann R. The payout phase of funded pensions plans: Risks and payment options. In: OECD PISA Financial Education Program. Madrid, Spain: BBVA Pensions Institute; 2014. Available from: https://www.jubilac iondefuturo.es/es/blog/la-fase-de-perce pcion-de-los-pagos-de-los-planes-de-pe nsiones.html

[8] Herce J, Bravo JM. Las pensiones en España y Portugal: Descripción de los esquemas y evolución reciente comparada. In: Es posible planificar la jubilación? Dos años del Instituto BBVA de Pensiones en España. Madrid, Spain: Instituto BBVA de Pensiones; 2015. pp. $89-126$

[9] Bernhardt T, Donnelly C. Pension Decumulation Strategies: A Stateof-the-Art Report. WP Actuarial Research Centre (ARC), The Institute and Faculty of Actuaries (IFoA); 2018

[10] Alho J, Bravo JM, Palmer E. Annuities and life expectancy in NDC. In: Holzmann R, Palmer E, Robalino D, editors. Non-Financial Defined Contribution Pension Schemes in a Changing Pension World, Volume 2: Gender, Politics and Financial Stability. Washington: World Bank Publications; 2012. pp. 395-436

[11] Bravo JM, El Mekkaoui N. Valuation of longevity-linked life annuities. Insurance: Mathematics and Economics. 2018;78:212-229

[12] Bravo JM. Pricing participating longevity-linked life annuities: A Bayesian model ensemble approach. Preprint submitted for publication. 2019

[13] Milevsky MA, Salisbury TS. Optimal retirement income tontines. Insurance: Mathematics and Economics. 2015; 64(1):91-105

[14] Chen A, Hieber P, Klein J. Tonuity: A novel individual-oriented retirement plan. ASTIN Bulletin. 2017; 49(1):5-30

[15] Bravo JM, Díaz-Giménez J. La longevidad es un riesgo asegurable? Cubriendo lo incubrible? In: Es posible planificar la jubilación? Dos años del Instituto BBVA de Pensiones en España. Madrid, Spain: Instituto BBVA de Pensiones; 2015. pp. 205-240

[16] Holzmann R, Ayuso M, Alaminos E, Bravo JM. Life cycle saving and 
dissaving revisited across three-tiered income groups: Starting hypotheses, refinement through literature review, and ideas for empirical testing. In: IZA Discussion Paper No. 12655. 2019

[17] Bravo JM, Herce JA. Career breaks, Broken pensions? Long-run effects of early and late-career unemployment spells on pension entitlements. 2019. Preprint submitted for publication in the Journal of Pension Economics and Finance

[18] Bravo JM, Silva C. Immunization using a stochastic process independent multifactor model: The Portuguese experience. Journal of Banking and Finance. 2006;30(1):133-156

[19] ECB. The household finance and consumption survey: Results from the second wave. ECB Statistics Paper No. 18. December - Household Finance and Consumption Network; 2016

[20] Bravo JM, Ayuso M, Holzmann R. Making use of home equity: The potential of housing wealth to enhance retirement security. In: IZA Discussion Paper Series No. 12656. Germany: IZA Institute of Labour Economics; 2019

[21] Ong R, Haffner M, Wood G, Jefferson T, Austen S. Assets, debt and the drawdown of housing equity by an ageing population. In: Positioning Overmortgage Paper No. 153.

Melbourne: Australian Housing and Urban Research Institute; 2013

[22] OECD. Pensions at a Glance 2013: OECD and G20 Indicators. OECD Publishing; 2013. DOI: 10.1787/pension_ glance-2013-en

[23] French D, McKillop D, Sharma T. Analysis of Housing Equity Withdrawal by its Forms. CHARMS-Centre for Health Research at the Management School; 2017. Working Paper Series 2017-04. Available from: https://ideas. repec.org/p/qub/charms/1704.html. [December 16, 2018]

[24] Simões C, Oliveira L, Bravo JM. Immunization strategies for funding multiple inflation-linked liabilities. 2019. Preprint submitted for Journal publication

[25] Chamboko R, Bravo JM. On the modelling of prognosis from delinquency to normal performance on retail consumer loans. Risk Management. 2016;18(4):264-287

[26] Chamboko R, Bravo JM. Modelling and forecasting recurrent recovery events on consumer loans. International Journal of Applied Decision Sciences. 2019;12(3):271-287

[27] Chamboko R, Bravo JM. Frailty correlated default on retail consumer loans in developing markets.

International Journal of Applied Decision Sciences. 2019;12(3):257-270

[28] Blake D. We need a national narrative: Building a consensus around retirement. The Report of the Independent Review of Retirement Income; 2016. Available from: http:// www.pensions-institute.org/IRRIRe port.pdf

[29] Bengen WP. Determining withdrawal rates using historical data. Journal of Financial Planning. 1994; 17(3):172-180

[30] Bengen WP. Conserving client portfolios during retirement, Part IV. Journal of Financial Planning. 2001; 14(5):110-119

[31] Pfau WD. An international perspective on safe withdrawal rates from retirement savings: The demise of the 4 percent rule? Journal of Financial Planning. 2010;23:52-61

[32] Pfau WD. Making sense out of variable spending strategies for retirees. 
Journal of Financial Planning. 2015; 28(10):42-51

[33] Zolt D. Achieving a higher safe withdrawal rate with the target percentage adjustment. Journal of Financial Planning. 2013:51-59

[34] Bravo JM, Corte-Real P, Silva C. Participating life annuities incorporating longevity risk sharing arrangements. Working Paper. 2009. Available from: rdpc.uevora.pt

[35] De Waegenaere A, Melenberg B, Stevens R. Longevity risk. De Economist. 2010;158(2):151-192

[36] Horneff W, Maurer R, Rogalla R. Dynamic portfolio choice with deferred annuities. Journal of Banking Finance. 2010;34(11):2652-2664

[37] Post T. Individual welfare gains from deferred life-annuities under stochastic mortality. Asia-Pacific Journal of Risk and Insurance. 2012;6(2)

[38] Hanewald K, Piggott J, Sherris M. Individual post-retirement longevity risk management under systematic mortality risk. Insurance:

Mathematics and Economics. 2013; 52(1):87-97

[39] Piggott J, Valdez E, Detzel B. The simple analytics of pooled annuity funds. The Journal of Risk and Insurance. 2005;72(3):497-520

[40] Valdez E, Piggott J, Wang L. Demand and adverse selection in a pooled annuity fund. Insurance: Mathematics and Economics. 2006; 39(2):251-266

[41] Milevsky M. Life Annuities: Optimal Products for Retirement Income. The Research Foundation of the CFA Institute; 2013. Available from: www. cfapubs.org

[42] Holzmann R. Addressing longevity risk through private annuities: Issues and options. In: Paper Prepared for the 22nd Annual Colloquium of Superannuation Researchers, CEPAR and ABS' School of Risk and Actuarial Studies, New South Wales University, Sydney. 2015

[43] Olivieri A, Pitacco E. Longevitylinked annuities how to preserve value creation against longevity risk. 2019. DOI: $10.2139 /$ ssrn. 3458441

[44] Bell D, Liu E, Shao A. Member's Default Utility Function for Default Fund Design Version 1 ("MDUF v1"). Sydney: Working Paper; 2017

[45] Vasicek O. An equilibrium characterization of the term structure. Journal of Financial Economics. 1977;5: 177-188

[46] Human Mortality Database. USA/ Germany: University of California, Berkeley/Max Planck Institute for Demographic Research; 2019. Available from: www.mortality.org or www.huma nmortality.de 



\title{
Chapter 2
}

\section{The Age Pension Means Tests: Contorting Australian Retirement}

\author{
Anthony Asher and John De Ravin
}

\begin{abstract}
Most Australian retirees are likely to be subject to the Age Pension assets or income test at some point. Evidence is that many retirees adapt their consumption to increase Age Pension entitlements, but long-term implications are difficult to determine-even if the current rules were to remain in place. This chapter evaluates the current approach to means testing against the principles set out in a Department of Social Services discussion paper on this topic. We evaluate the implied "effective marginal tax rates" (EMTRs) on the assets of part pensioners who are subject to the assets test. We find that depending on a variety of parameters such as assumed future earnings rates, demographic status, drawdown strategy and the base level of assets held, the EMTRs are high enough to explain material distortions to savings decisions of those still in employment, and the spending and investment decisions of retirees. Optimal decisions in this context require contorted retirement strategies that do not appear to be in anyone's interest. Some possible remedies are suggested, which should include incorporating the value of the principal residence within the assets test. The chapter therefore illustrates the application of principled analysis to policy issues of this sort.
\end{abstract}

Keywords: assets test, effective marginal tax rate, Age Pension, taper rate, equity

\section{Introduction}

This chapter evaluates the means tests that apply in Australia against alternative principles that can be applied to evaluate the integration between the first and second pillars of a retirement income system. Central to the analysis are the Effective Marginal Tax Rates (EMTRs) that apply to the first pillar when subject to the means tests.

\section{The Age Pension and means tests}

The Australian retirement income system consists of two main pillars: the means tested Age Pension (AP) and Superannuation [1]. The first pillar is a welfare benefit that is means tested and funded from general government revenue. The superannuation system consists mainly of privately administered funds in which members have investment accounts into which mandated contributions are paid. Members are able to take tax free lump sums from the age of 60 , but many choose to withdraw "account-based pensions", which allow members to vary the amount drawn - subject to a regulated minimum proportion of their accounts. A third pillar consists of voluntary savings including the home. 
There are currently two separate components of the means tests, the income test and the assets test, and homeowners are treated differently from non-homeowners. The means test rules are Byzantine in their complexity and change frequentlysometimes with considerable effects on some groups of pensioners. The following description omits many details on the grounds of immateriality.

\subsection{The Age Pension}

The AP dates back to the formation of Australia with Federation in 1909, the amounts being shown in Figure 1. It has increased roughly in line with average wages, with a particular boost under the Whitlam government of the early seventies. Relative to minimum wages, it has approximately doubled over the past century, which means that pensioners are better off relative to workers on lower incomes. This shift has partly been a response to old age poverty, but may also reflect the relative political influence of these two groups.

\subsection{The means tests}

Figure 1 also traces the development of the income and asset test free limits over the century. The two tests were merged between 1961 and 1985. Before 1969, pensions were not payable to those over the means test free limits, although between 1953 and 1971 assets were converted into income at a rate of 10\%. From 1969, taper rates (the rate at which the AP is reduced as a proportion of the relevant means) of $50 \%$ have applied on income except for a period from 2000 to 2009 when they were reduced to $40 \%$. The taper rate on the asset test seems to have been set at $7.8 \%$ except from 2007 to 2016 where it was only $3.9 \%$.

\subsection{Description of current means tests}

The current AP for a married couple owning their own home is slightly in excess of $\$ 36,000$ per annum, reduced by the greater of $50 \%$ of income over $\$ 7800$ p.a. or by $7.8 \%$ of assets over a threshold of $\$ 394,500$. Single pensions are a relatively generous $66 \%$ of those paid to a couple.

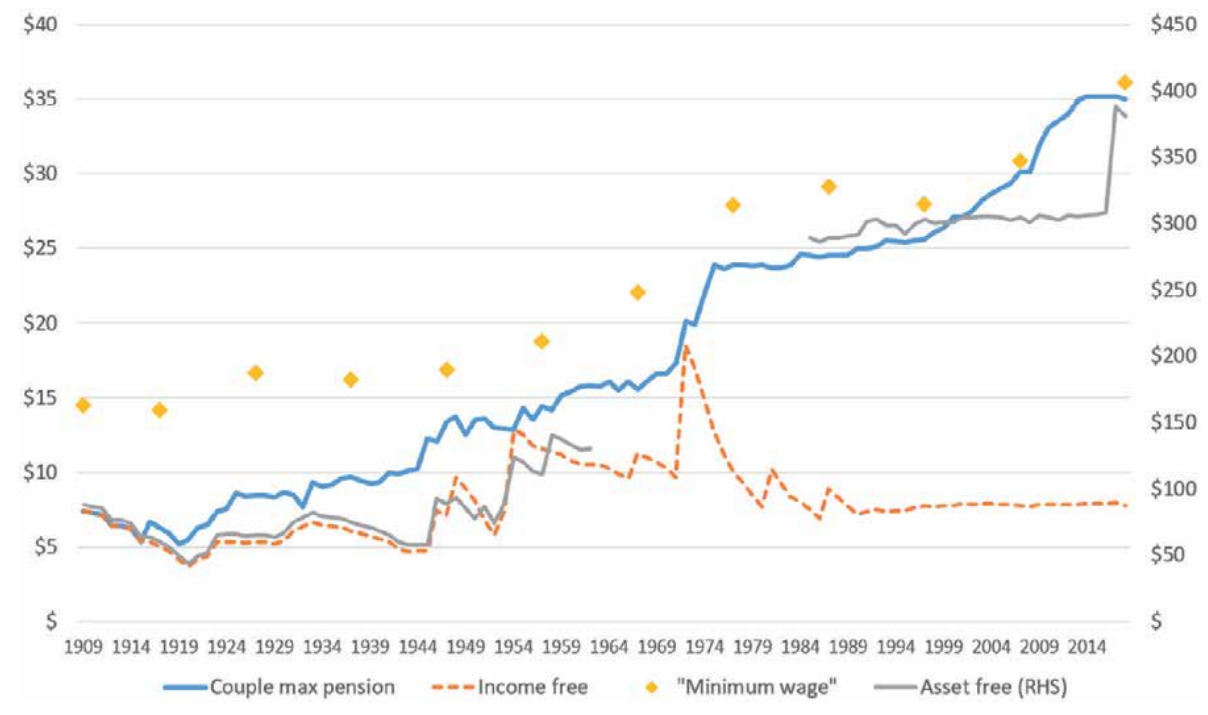

Figure 1.

History of AP and means tests-couples. 
Those who are renting qualify for rental assistance of $\$ 3588$ for singles butstrangely-only $\$ 3380$ if a couple. The asset test limits for non-homeowners are also some $\$ 200,000$ higher than for homeowners.

The Australian means tests appear to be particularly complex and Australian pensioners on a wider range of incomes and with a wider range of assets are affected by the taper rates under the means tests than pensioner residents of other countries [2].

The Department of Social Services (DSS) explains and justifies the means tests thus: “The means test functions to assess a person's overall capacity for self-support and target social security expenditure according to need.... Means testing also provides incentives for self-provision in the form of participation and saving. The means test balances these objectives by the use of income and assets free areas and the tapered withdrawal of payment as a person's assessable income and assets increase" [3].

\subsection{Evaluation criteria}

The DSS discussion paper [3] also lists the criteria against which the current means testing system should be judged. Those principles need to encompass the treatment of a variety of types of asset (especially annuity and deferred annuity products) as well as financial and other investments and physical assets.

- "Neutrality—-the means test assessment of investments should not advantage a particular type of product or provide an incentive for people to invest in a particular asset ...

- Equity-the rules should treat people with similar means in a consistent way (horizontal equity) and those who have a greater capacity to self-provide for their retirement should receive lower income support (vertical equity).

- Resilience-the rules should be able to apply to a range of products, including new products, without diminishing neutrality and equity ...

- Integrity-the rules should ensure the social security system remains targeted to assisting those people who need support and that people cannot maximise their Age Pension by engaging in strategies that minimise the extent to which their own income or assets are counted in means test assessments.

- Fiscal sustainability-the means test treatment of new retirement income stream products should have regard to the cost of the social security system.

- Simplicity - the rules should be easy to understand for income support recipients, financial advisors and income stream providers. Complicated rules can result in people making poor financial decisions. Simple rules support people to make good decisions."

We have no argument with these principles. This chapter, however, argues that the asset test is especially inequitable to the cautious who retain assets for precautionary purposes; makes planning extremely complex; and significantly distorts the investment and drawdown behaviour of many retirees. It therefore fails all the policy principles except possibly that of fiscal sustainability. There are alternative approaches that could better meet these principles including fiscal sustainability. 


\section{Housing}

While not the main point of this chapter, the difference in treatment between home-owners and renters is egregiously inequitable, and needs to be discussed first as it would not be complex to address, and the adjustment could be performed in a manner which would be revenue-neutral.

\subsection{Poorer renters}

The pressing issue is the dire position of those who neither own their own home nor have access to social housing. Given that only $10 \%$ (or about 200,000) of such properties had rents of less than $\$ 10,000$ annually in 2011 [4], rent assistance of $\$ 3588$ p.a. places considerable financial stress on those non-homeowners with limited other resources, many of whom are reduced to poverty or homelessness. Unpublished data from the Australian Department of Social Services shows 32,000 homes, where people are aged 65 and above and receiving rent assistance, are paying unaffordable rents in NSW [5]. It is a 50\% rise in the past five years and includes 9000 people, 65 and over, who are paying more than half their income on rent.

Given that there are some 1.2 million people over 65 in NSW, this implies that about $2.5 \%$ of the aged population face the problem-90,000 country-wide. We make no detailed calculations as to precisely what would be fair, but suggest that the amount should be more or less doubled. While $\$ 6000$ p.a. is not enough to fully cover rent, homeowners do face significant costs that would have to be considered in detailed modelling. Doubling rent assistance to pensioners not in social housing would cost less than $\$ 200 \mathrm{~m}$, which is close to $0.25 \%$ of the cost of support to the aged.

\subsection{Richer homeowners}

At the other end of the financial spectrum, the exemption of the home from the asset tests means that there may well be as many pensioners receiving the AP while living in multi-million dollar houses. Particularly given that dwellings and land represent over $50 \%$ of the household balance sheet, an exemption seems myopic and distorts financial planning, spending, investment and the price of housing $[6,7]$. The DSS discussion paper justifies it so:
"The exemption of the principal residence from the assets test recognises the greater financial security that pensioners have if they live in their own home and impor- tance placed on the family home in Australian society."

While these assertions are clearly true, the rational conclusion would be to include homes in the assets test rather than exclude them precisely for these reasons. Home ownership does provide financial security so those who rent need to be given more, while those who obviously have secure lodgings need less social support. The "importance placed on the family home" emphasises this. For many, however, the "family home" has three empty bedrooms and is crumbling around the surviving parent, who is increasingly unable to manage the activities of daily living, let alone maintain the house. But the homeowner is not willing to downsize to a less expensive and more manageable property, sometimes for psychological reasons but often also because of the negative impact on their main source of income, the AP.

Each of the criteria mentioned in Section 2.4, except perhaps simplicity, demand the inclusion of the principal residence. The arguments against ignore the 
disadvantages faced by renters. Homes provide an imputable rent and the AP should be adjusted if pensioners decide to spend more on it.

The need to include the value of the house in the asset test has been recommended by almost all who have considered the question. There have been eight different recommendations in as many years: the Harmer Pension Review, the Henry Review, a Grattan Report, three Productivity Commission reports, Rice-Warner and the National Commission of Audit [8]. It seems overwhelmingly clear that affordability issues should be addressed by including the value of the home.

\subsection{The right to housing security and fungibility}

There are two reasons to distinguish one source of wealth from another. The first is the basic human right of housing security; the second is fungibility. These two can explain much of the visceral response of some people when suggestions are made to include the home in the means tests. The right to housing has a simple logic: if people do not have their own place, they must occupy someone else's. This right must include some security of tenure to be meaningful, and without some security and protections for both renters and owners the incentive to care for and improve the place is absent. Addressing the lack of security enjoyed by renters is the subject of another debate. Those interested in some of the theoretical and political controversies might like to refer to Hayward [9].

The problem of fungibility is that the home cannot easily be turned into income. Conventional reverse mortgages are relatively expensive and, given the normal operation of compound interest, may lead to significant reductions in the net residual value of the home which might constrain future choices if the borrower wishes to move into other accommodation. There is also a government scheme (the "Pension Loans Scheme") that lends the AP shortfall to part pensioners. The interest rates charged are a little lower than commercial reverse mortgages but more restrictions apply to eligibility and the manner of drawdown of funds.

If the value of the home is to be included in the means tests, then the lack of fungibility means that some pensioners at least will be worse off. Johnson and colleagues [8] refer to a growing consensus for effective instruments to address the issue of fungibility, and refers to some commercial schemes including those that share capital appreciation.

Careful consideration would need to be devoted to transitional arrangements so that inclusion of the home (or the excess of the value of the home above some threshold value) does not bear unreasonably harshly on those pensioners who have already retired, in the expectation that the current means testing rules will continue to apply (perhaps with slight adjustment to parameters) throughout their retirements.

\section{Integrating the superannuation and AP systems}

The key issue addressed by this chapter is the way by which the AP is reduced by financial assets-including those in superannuation funds. As will become clear in this section, the issue is not simply the "taper rate" (the rate at which the AP is reduced in relation to assets held above the assets test threshold), because the long-term effects are very different for different approaches to the drawdown of the superannuation balance.

We take it as given that the objective of the superannuation system is to provide for consumption in retirement, and that the AP supplements this for those who do not have the means to support themselves. One important consequence of this 
is that superannuation benefits are to be seen as a mechanism for supporting the lifestyle of retired Australians, not as a mechanism by which the real capital value of a pensioner's estate is maintained or grown, to be passed to non-dependents. The current dominance of account-based pensions does not achieve this result, and we could argue that the pooling of longevity risk should be encouraged by the means tests. This is however not the main thrust of this chapter, which is the unfairness and distortions created by the asset test.

\subsection{Concept of effective marginal tax rates (EMTRs)}

In each case, we consider the marginal losses to AP entitlements that arise from having assets over the thresholds. We refer to these as EMTRs. Legally, the tapers in the AP are not "taxes", but given that money is fungible, the loss of social security entitlements caused by having additional assets is effectively the same as a tax.

\subsection{Those who do not draw down}

Figure 2 illustrates EMTRs for those who retain their assets and spend their income. It applies at any one time, and would apply over a lifetime to a single person and show the results of earning a real rate of interest of 3\% and another earning $5 \%$. The assets test creates a trough in income between about $\$ 300,000$ and $\$ 700,000$ in assessable assets. Within the assets testing range where the assets test produces a lower AP entitlement than the income test, annual income declines with increasing assets because the income from the marginal assets (whether returning 3\% p.a. or $5 \%$ p.a.) is less than the AP foregone, which is $7.8 \%$ p.a. The calculations do not consider any investment volatility.

\subsection{Definition of "lifetime EMTRs" and approach to calculation}

A more complete picture may be obtained by considering the impact of holding additional assets over the course of a retiree's lifetime. We do this for a variety of asset levels and drawdown strategies. We also vary the following:

- Assumed future real rates of investment return on assets

- Drawdown strategy adopted

- Demographic status (single male/single female/couple)

- Initial level of assets held

For purpose of our calculations it may be helpful to define "lifetime EMTR" as follows:

$$
\text { Lifetime EMTR }=\{\mathrm{PV}(\mathrm{AP} ; \$ \mathrm{X} ; \mathrm{DS})-\mathrm{PV}(\mathrm{AP} ; \$ \mathrm{X}+\delta ; \mathrm{DS})\} / \delta
$$

where $\$ \mathrm{X}$ is the base level of assets held when the pensioner first becomes eligible for AP; $\$ \delta$ is an incremental amount of assets in addition to $\$ \mathrm{X}$ hypothetically held when the pensioner first becomes eligible for AP; DS refers to a specified Drawdown Strategy; PV (AP; \$X; DS) is the present value of AP received over the lifetime of the single of couple pensioner assuming initial assets of $\$ \mathrm{X}$ and that the pensioner follows drawdown strategy DS. 


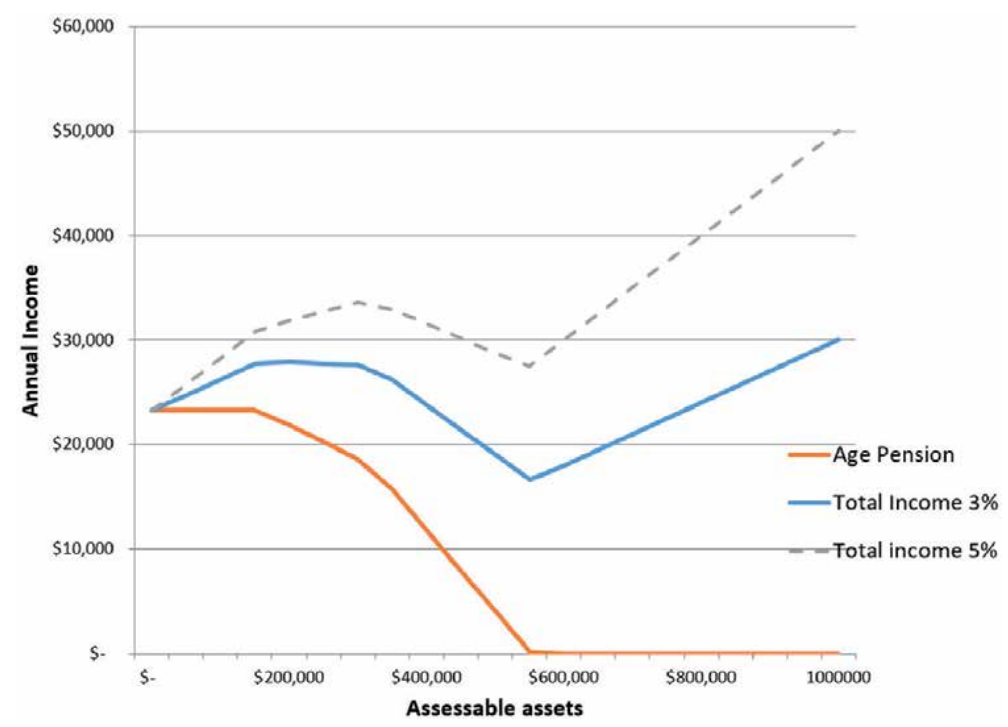

Figure 2.

The asset trough for those who retain assets.

In other words, the lifetime EMTR is the present value of the future loss of AP due to holding additional assets $\$ \delta$ at age pension eligibility age, as a percentage of those additional assets. A lifetime EMTR of zero means that the pensioner has incurred no loss of AP as a result of holding an additional $\$ \delta$ of assets, while a lifetime EMTR of $100 \%$ would mean that the pensioner has effectively received no net value from the additional $\$ \delta$ of assets.

For some of the results in this chapter (especially in Section 5.1 below) we have taken $\$ \mathrm{X}$ to be the lower assets testing threshold and $\$ \delta$ to be the width of the asset testing range (i.e. from the threshold to the level of assets where the AP is zero). The EMTR is therefore the impact of holding additional assets equal to the width of the asset testing range, relative to holding assets of an amount equal to the lower assets test threshold. We have also performed a set of calculations for smaller tranches of incremental assets, for drawdown strategies in the following specific forms:

1. Asset drawdown each year is the regulated minimum required as a proportion of the beginning of year assets. We have also calculated EMTRs for annual consumption expenditure from $1 \%$ to $5 \%$ higher than the minimum-in $1 \%$ increments.

2. Asset drawdown each year is a fixed percentage of the beginning of year assets. The fixed percentages for which we evaluated EMTRs were varied from $5 \%$ to $15 \%$ in multiples of $2.5 \%$.

The asset testing range for a single pensioner is approximately $\$ 300,000$ in total width (from $\$ 253,750$ to approximately $\$ 552,000$ ). We have taken $\$ \delta$ for single pensioner calculations to be $\$ 100,000$, and have therefore calculated three separate EMTRs for the asset testing range. Similarly, the asset testing range for pensioner couples is very nearly $\$ 450,000$ in total width and we have taken $\$ \delta$ for calculations involving couples to be $\$ 150,000$.

In total we have done six computations of EMTRs for each drawdown strategy, demographic status and rate of real investment return considered, reflecting 
marginal lifetime losses of AP from holding an additional $\$ 100,000$ of assets (for singles, and $\$ 150,000$ for couples) at the date of becoming eligible for the AP. Three of the calculated EMTRs apply within the asset testing range and three to assets in excess of the asset testing range but where the additional assets held will result in the loss of AP not immediately, but after a period of time when the assets are depleted to an amount within the asset testing range.

Table 1 shows the parameters for each of the six sets of calculations.

The results of these detailed EMTR evaluations are reported in Section 5.2 below.

\subsection{Assumptions}

Table 2 summarises the assumed AP parameters that we have used for the purposes of the detailed calculations in this chapter. (The parameters in Table 2 were those that applied between September 2017 and March 2018; however we note that most of the parameters below change only gradually over time, due to indexation).

Also implicitly we have assumed, by using a real rate of investment return (where by "real" we mean relative to average weekly ordinary time earningsAWE) that future rates of AP payment will be indexed to AWE and also that future lower and upper thresholds for the assets test and income test will also be indexed to AWE. Current practice is for AP payment amounts to be indexed normally to AWE but threshold amounts are indexed to CPI; nevertheless for simplicity of calculation, both payment amounts and thresholds have been assumed to be indexed to AWE. If we had used CPI, the EMTRs reported would still apply, but at slightly different levels of assets.

\begin{tabular}{l|cccc}
\hline & \multicolumn{2}{c}{ Singles (\$000s) } & \multicolumn{2}{c}{ Couples (\$000s) } \\
\hline & $\mathrm{X}$ & $\delta$ & $\mathrm{X}$ & \multicolumn{1}{c}{$\delta$} \\
Lower third of assets test range & 253 & 100 & 380 & 150 \\
Middle third of assets test range & 353 & 100 & 530 & 150 \\
Upper third of assets test range & 453 & 100 & 680 & 150 \\
First layer above upper limit & 553 & 100 & 830 & 150 \\
Second layer above upper limit & 653 & 100 & 980 & 150 \\
Third layer above upper limit & 753 & 100 & 1,130 & 150
\end{tabular}

Table 1.

Asset ranges.

$\begin{array}{lr}\text { AP Single } & 23,254 \\ \text { AP Couple } & 35,058 \\ \text { Lower AT Threshold Single } & 253,750 \\ \text { Lower AT Threshold Couple } & 380,500 \\ \text { AT Taper Rate } & 7.80 \% \\ \text { Lower deeming rate } & 1.75 \% \\ \text { Higher deeming rate } & 3.25 \% \\ \text { Deeming threshold - Single } & 50,200 \\ \text { Deeming threshold - Couple } & 83,400 \\ \text { Income test threshold single } & 4,368 \\ \text { Income test threshold couple } & 7,800 \\ \text { Income test taper rate } & 50 \%\end{array}$

Table 2.

AP projection assumptions. 


\section{Results}

The results below show first the extent to which alternative strategies can contribute to significantly higher AP benefits over a lifetime. Then, in Section 5.2, we show the EMTRs that apply to retirees subject to different circumstances when they use the alternative strategies.

\subsection{Annual income and division of benefits}

Figure 3 shows the lifetime effects (until age 109) of the various strategies for a single pensioner. We have assumed assets exactly equal to the top of the asset test level, which produces the largest impact-for illustration purposes.

The first strategy is for the pensioner to draw down the minimum permitted by superannuation regulations. Her spending is shown as the unbroken Minimum drawdown line in Figure 3. This is the strategy we understand is adopted by approximately half of pensioners, more than any other strategy [10]. Its presence in regulations as a minimum gives it an implicit authority and we have taken it as an effective benchmark. Her spending pattern is however totally inappropriate-starting at $\$ 28,000$ p.a. at 67 and rising to $\$ 48,000$ at 85 before declining again. We have also calculated the actuarial present value of the benefits to the member, her dependents and as a reduction in AP. The value of her assets at the beginning of retirement is shared into roughly equal thirds: one to herself, one to her heirs, and one in fiscal savings. That means tests are structured to permit the heirs to inherit a third of the superannuation benefit represents a lack of targeting of superannuation and the means tests.

A second strategy is to give away enough of her assets to escape the asset test altogether, which the regulations require her to do before 62-five years before becoming entitled to the pension. She then draws down at the minimum rate. This dashed line shows somewhat bizarrely that, at 67 , her income is $\$ 6000$ p.a. (20\%) higher than if she had not given the money away. This amount falls slightly after her mid-eighties, but it is reasonable level and appropriate. Her share of the benefits drops only slightly to $29 \%$, because the savings to the fiscus is minimal, with its proportion dropping to $2 \%$ (via deemed income caught by the income test). The heirs' share more than doubles to $69 \%$ - $\$ 260,000$ of which they receive before the pensioner reaches the age of 62. This is by far the most fiscally efficient for the pensioner and family. Rather than be given away, the money could be invested in her residence or spent before the pension age. The alternatives, singly or in combination, would allow the pensioner to directly enjoy $98 \%$ of her savings.

A third alternative is for the pensioner to spend the money after retirement in order to maintain the "comfortable lifestyle" determined by the Association of Superannuation Funds of Australia (ASFA) [11] until she falls below the asset test threshold, after which she reverts to the minimum. The income is shown in the Comfortable line in Figure 3. She enjoys a 50\% higher standard of living than the benchmark, and remains above it until her early eighties. Her share of her savings rises to a little over $50 \%$, with her heirs and fiscal savings sharing the balance.

A final alternative therefore is a level lifetime annuity. The total income and the amount provided by the annuity plus Age Pension are shown by the dotted and dashed lines. The present value is shared $70 \%$ to the pensioner and the balance to the fiscus.

\subsection{Analysis of EMTRs for small tranches of incremental assets}

In addition to the broad calculations of EMTRs referred to in Section 5.1 above, we have computed EMTRs for smaller values of $\delta(\$ 100,000$ for singles and 
$\$ 150,000$ for couples). The objective of these calculations was to gain additional insight into the extent to which asset-testing rules impacted EMTRs as a function of base asset levels, investment returns and drawdown strategy combinations.

For these more granular calculations a slightly different approach was taken to mortality assumptions than in the calculations underlying Appendix 1 and Section 5.1. In particular it was assumed that a single female would receive AP for 25 years and a single male would receive AP for 22 years. These durations are slightly higher than the life expectancies for a 65-year-old according to Australian Life Tables (ALT) 2010-2012, which are 22.05 and 19.22 years for females and males respectively. Ongoing improvement to mortality means that current age-specific mortality in Australia is lower than mortality rates that applied during the 2010-2012 triennium and is likely to continue to decline in future.

For couples, it was assumed that the couple rate of pension would be payable for 22 years and the single rate for a further 5 years. This is because the expected age at death of the last to die from a couple is greater than the expected age at death of either considered separately.

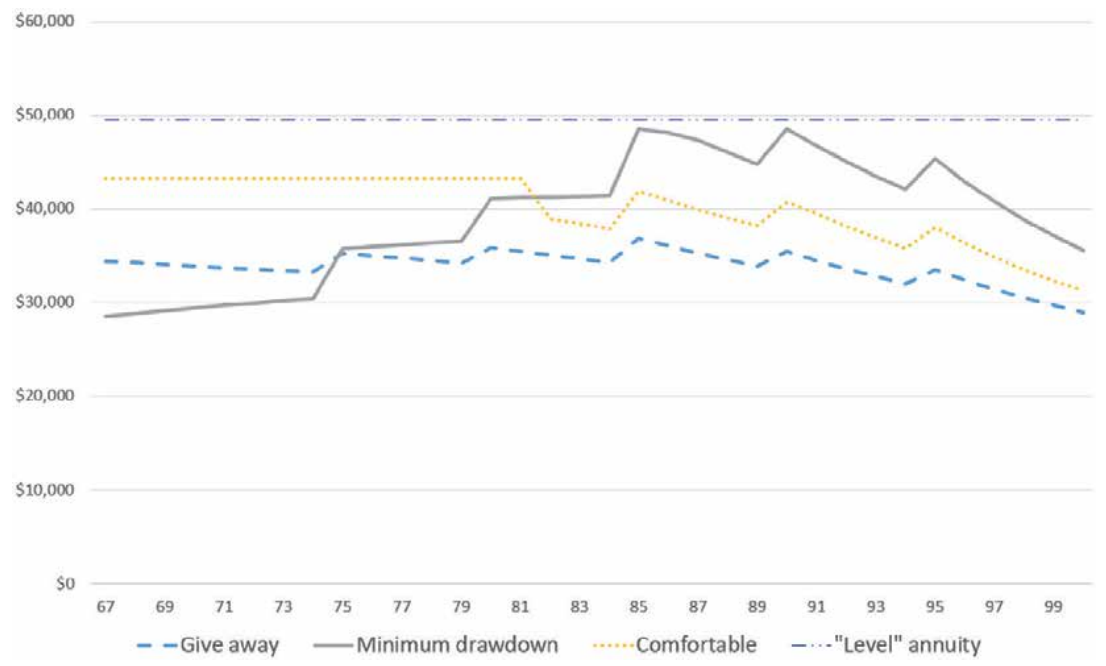

Figure 3.

Alternative retirement consumption patterns.

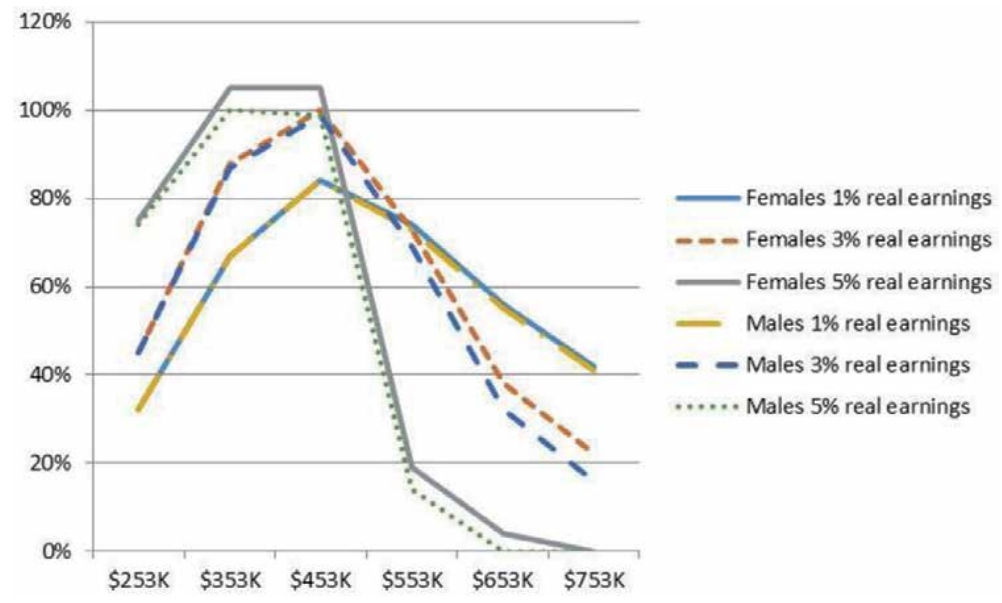

Figure 4.

EMTRs based on drawing down the regulated minimum—single pensioners. 
The drawdown strategies allowed for are those detailed in Section 4.3 above.

Figure 4 shows EMTRs for a single pensioner using the minimum drawdown strategy we use as a benchmark.

The curves show the EMTR of a marginal additional of $\$ 100,000$ of assets at the eligibility age for the AP, valued over the lifetime of the pensioner. We note from Figure 4 that female EMTRs are slightly higher than the corresponding male EMTRs, due to the longer life expectancy of females. This means that they have more time to lose AP to the means tests.

The effect of different investment earnings is significantly greater than those for the two genders. For example, the $5 \%$ real interest curves fall away more steeply for base asset level of $\$ 553,000$ or more (that is, at or above the upper assets test threshold). This occurs because the $5 \%$ real interest rate will tend to mean that, if assets are at or above the upper asset test threshold when the pensioner attains eligibility age, then the value of assets will remain above the upper threshold over the entire lifetime, and no further AP is foregone. However if assets are within the asset testing range at AP eligibility age, they will remain between the thresholds for longer so increasing the loss of AP. At lower rates of real interest, the asset values are depleted more quickly over time with the result that less AP is lost at lower starting balances. Assets over the upper threshold depreciate faster, so more is lost from an incremental $\$ 100,000$.

Finally, the most significant observation is just how high the EMTRs are, throughout the asset testing range (especially in the middle and upper thirds of the asset testing range). Top marginal income tax rates in Australia are currently only $47 \%$, so any EMTR in excess of this appears unfair and provides an incentive to adopt means test avoidance strategies. EMTRs in the range of $80 \%, 90 \%, 100 \%$, or even higher represent a very powerful incentive to:

- Give money away 5 years prior to attaining eligibility age;

- Spend down rapidly in the first few years on pension;

- Spend money on house renovations, or even purchase a more expensive property; or finally,

- Not save in the first place. This can involve higher borrowing at younger ages to be repaid by superannuation lump sums, or retire early and draw them down before qualifying for the AP.

All of these are obviously distortions to the economic decisions that the preretiree would otherwise have made. Those who adopt such strategies will also be an increased burden on the public purse.

\section{Evaluation}

While the results will vary significantly depending on the underlying assumptions, one can draw three conclusions from these calculations:

1. Pensioners are penalised, and greater fiscal savings accrue, the longer pensioners retain their asset-testable assets.

2. The penalties can be reduced by giving money directly to heirs, by spending the money faster, and especially by investing in the family home. These actions are therefore incentivised. 
3. There are very significant gains that can be made by adopting different drawdown strategies. Determining an optimal strategy is however complex for pensioners, made more difficult by ongoing changes in the means test rules. Forecasting is also difficult for government as pensioners change their strategies in response to the incentives.

\subsection{Evaluation against the criteria}

We now consider whether the system meets the criteria set by the DSS.

\subsubsection{Neutrality}

The current structure of the asset test is not neutral when the rules are applied over a lifetime. Annuities do enjoy relatively favourable treatment relative to applying the minimum drawdown to an account-based pension, but the latter allows for flexibility that can be used to manipulate the rules to the point of avoiding the asset test entirely.

\subsubsection{Equity}

The current system creates significant inequities.

- Horizontal inequity arises for people with the same level of wealth (which is at one level fungible). Non-homeowners with $\$ 1$ million in assets will get no AP, while homeowners with a house of that value will draw the whole AP.

- Vertical inequity arises when the differences in treatment applied to people are not proportional to the differences in their characteristics. The dramatically higher taper applied by the asset test does not seem proportionate, neither does the failure to differentiate between those with valuable houses and those with small apartments.

- The asset test fails to provide vertical equity for those with different life expectancies. Most important is that they penalise younger retirees at the expense of older ones. A couple of 67 with $\$ 1$ million in assets, which could generate investment income of about $\$ 50,000$ p.a., cannot afford the ASFA comfortable retirement standard. A couple of 90 in the same position could afford to spend $\$ 100,000$ p.a., well above the comfortable level.

- Women also need more than men to maintain the same spending given their greater expected longevity. Arguably the assets tests are discriminatory as they advantage men (who require less) than women.

- Regional differences in rent and the cost of living also create vertical inequities, although in this case people do have the ability to move to less expensive areas.

- Those who can obtain appropriate advice and are able to act on the advice can avoid the worst consequences of the tests. Their complexity however makes it very difficult to make the right decisions. This means that the costs are borne by the less well informed, the cautious, and possibly by those who regard it as anti-social or degrading to be supported by welfare. 


\subsubsection{Integrity}

The current system completely fails the integrity test as defined by the DSS, quoted in Section 2.4 above. There is a clear failure to adequately address some of the most indigent whose rental costs leave little else to live on. It also fails to limit access to the AP by pensioners with significant housing assets.

It is also far too easy for retirees to adopt a range of strategies that mean that they will obtain a much greater share of the AP than those who are not so well advised or who do not wish to pursue the strategies we identified.

\subsubsection{Resilience and fiscal sustainability}

The desired level of fiscal expenditures could be maintained by incorporating the principal residence into the assets test and adapting the quantum of the $\mathrm{AP}$ and the parameters governing the means tests. In times of fiscal constraints, all Australians should expect to bear some of the burden and pensioners as much as anyone should expect smallish reductions in their standard of living at times. Transitional arrangements should apply for some limited period to mitigate the impact of the changes on those most adversely affected by the changes.

\subsubsection{Simplicity}

Benefits cannot be targeted precisely at those that need them. Needs are complex and fluctuating; evaluation methods inevitably somewhat simplistic, limited to a particular time and prone to error. Bradshaw and Finch [12] looked at three different approaches to measuring poverty; "lacking socially perceived necessities; being subjectively poor and having a relatively low income... we have found that there is little overlap in the group of people defined as poor by these dimensions."

The different levels of AP and associated supplements, and permutations of the means tests create an entirely spurious impression of targeting needs. The trivial nature of some of the supplements and concessions, such as the lower deeming rate for the income test, are not only wasteful of energy but bring the whole system into disrepute. This is particularly true when material differences such as housing are not taken into account.

Maeda [13] suggests that the three laws of simplification are reduce, organise and save time. Reduction and saving time are obvious. Organisation may not be. For instance, Schedule 7 of the Superannuation Industry (Supervision) Regulations 1994 (SIS Regulations), which has 7 categories for minimum drawdown amounts for different age bands, can be seen as more complex than Schedule $1 \mathrm{~A}$, which has 80 categories for each age from 20 to 100 . This is because one cannot remember all 7 categories so that they both have to be looked up, but changing the factor each year is more intuitive and so easier to understand, to administer and creates a smoother cash flow.

The suggestions made below in Section 7, would not only be simpler, but more clearly meet the criteria that have been mentioned: neutrality, equity, integrity and resilience.

\subsection{Perversity}

Failure to meet these principles creates perverse outcomes. We have shown that there is a strong incentive to draw down quickly or move assets into the family home. It appears retirees do both. While only $19 \%$ of couple pensioners are subject 
to the asset test, rough calculations suggest that over a third of those over 65 should be in this category. An analysis of Centrelink data suggested that those pensioners subject to the asset test draw down their assets up to $10 \%$ faster [14].

\section{Options for reform}

We suggest the following remedies for the problems identified.

\subsection{Revert to former asset test taper rate}

One policy option would be to revert to the former $3.9 \%$ asset test taper rate that applied between 2007 and 2016. Such a solution would mitigate the extremely high EMTRs that currently apply especially in the upper parts of the asset testing range and therefore reduce the attractiveness of strategies designed to increase age pension entitlements.

If the taper rate were reverted to $3.9 \%$, there would need to be changes in the upper and/or lower assets test thresholds. For example the thresholds could revert to something like the pre-2016 asset testing thresholds (but with indexation adjustments). However if the opportunity were taken to include the principal residence in the means tests, then the lower threshold should be increased markedly, by something like the value of a basic home.

\subsection{Abolish the asset test and convert superannuation into an income stream}

A simpler solution is to abolish the asset test, which so contorts the retirement system and the lives of most Australian pensioners. Assets should be converted into a lifetime income (for the couple and other dependents if relevant). This can be done by dividing annually the value of assets by the Pension Valuation Factors (PVFs) in Column 4 of Schedule 1A of the SIS Regulations for singles, and using higher PVFs for couples.

This would lead to higher AP costs in the short run, but there would be no increase in AP payments as people age and the thresholds could be calibrated for the change to be fiscally neutral.

The additional fiscal costs in the short term can also be covered by including the value of the principal residence at an imputed rent. Rent assistance would be payable to everyone, further simplifying the system. The net impact would be felt most by people with low financial assets and expensive houses. Assuming an annuity rate of $7.5 \%$ at age 65 , a deeming rate of $4 \%$ and a doubling of rental assistance, Table 3 shows the annual gains and losses.

Single renters of moderate means would be the main winners. There are however very few of them currently, but removing the incentive to hold onto a home might well increase numbers.

The main losers would be homeowners with minimal financial assets. Their loss of spending power could be addressed by an expanded Pension Loans Scheme. Under the existing scheme, part pensioners can be lent the difference between $150 \%$ of the full AP and the part AP for which they qualify. Centrelink would take ownership of a proportion of the value of the home that this represents. As the loss of pension is only $2 \%$ of the value of the house (under the second proposed scenario), they could borrow for many years before exhausting the value of the house. A "no negative equity" guarantee would have a trivial cost. 


\begin{tabular}{|c|c|c|c|c|c|}
\hline \multirow[b]{2}{*}{$\begin{array}{c}\text { FINANCIAL } \\
\text { ASSETS }\end{array}$} & \multirow[b]{2}{*}{ HOUSE } & \multicolumn{2}{|c|}{ SINGLE } & \multirow[b]{2}{*}{$\begin{array}{c}\text { Current } \\
\text { AP }\end{array}$} & \multirow{2}{*}{$\begin{array}{c}\text { COUPLE } \\
\text { Proposal } \\
\text { gain }\end{array}$} \\
\hline & & $\begin{array}{c}\text { Current } \\
\text { AP }\end{array}$ & $\begin{array}{l}\text { Proposal } \\
\text { gain }\end{array}$ & & \\
\hline 250,000 & - & 26254 & 3000 & 38058 & 3000 \\
\hline 500,000 & - & 7047 & -2627 & 38058 & -1481 \\
\hline 750,000 & - & 0 & 7498 & 24837 & 2365 \\
\hline $1,000,000$ & - & 0 & 1270 & 0 & 12490 \\
\hline 250,000 & 600,000 & 23254 & -5859 & 35058 & -1106 \\
\hline 500,000 & 600,000 & 4047 & 3973 & 25737 & -1160 \\
\hline 750,000 & 600,000 & 0 & 0 & 6237 & 8965 \\
\hline $1,000,000$ & 600,000 & 0 & 0 & 0 & 5827 \\
\hline 250,000 & 800,000 & 23254 & -9859 & 35058 & -5106 \\
\hline 500,000 & 800,000 & 4047 & -27 & 25737 & -5160 \\
\hline 750,000 & 800,000 & 0 & 0 & 6237 & 4965 \\
\hline $1,000,000$ & 800,000 & 0 & 0 & 0 & 1827 \\
\hline 250,000 & $1,000,000$ & 23254 & -13859 & 35058 & -9106 \\
\hline 500,000 & $1,000,000$ & 4047 & -4027 & 25737 & -9160 \\
\hline 750,000 & $1,000,000$ & 0 & 0 & 6237 & 965 \\
\hline $1,000,000$ & $1,000,000$ & 0 & 0 & 0 & 0 \\
\hline
\end{tabular}

Table 3.

Potential gains and losses due to proposed changes.

\subsection{Personal responsibility and political games}

The problems with the existing system are clear. It cannot be justified, but the dire state of much current political debate means that the problems remain running sores. There is a clear need for bi-partisan agreement not to resort to irrational sound bites. Such an agreement needs to include the major industry players and media commentators. Those who exploit the uncertainty that will naturally be felt by many pensioners need to be openly and quickly rebuked. The current awareness of the damage caused by manipulated outrage may offer an opportunity for sensible discussion.

At the very least, if change is to be made, politicians and commentators will need to be courageous and to make a stand for what it right rather than attempt to score points.

\section{Conclusion}

The means tests in their current format make it exceptionally difficult to plan for any pattern of spending in retirement-as the Age Pension increases with reductions in assets and income in a way that is difficult to understand and model over a retired lifetime. They also provide very strong incentives for pre-retirees to engage in a range of strategies to maximise their age pension. Apart from the unnecessary fiscal burden that such strategies impose on taxpayers, they also distort savings and consumption decisions and asset prices (especially of the principal residence) and cry out for change. 


\section{Acknowledgements}

This chapter is an extension of [15], a public submission in response to the Department of Social Services discussion paper [3]. Quotations from the earlier paper are therefore not marked.

\section{Conflict of interest}

The authors declare no conflict of interest.

\section{Author details}

Anthony Asher ${ }^{1 *}$ and John De Ravin ${ }^{2}$

1 University of New South Wales, Sydney, Australia

2 Sydney, Australia

*Address all correspondence to: a.asher@unsw.edu.au

\section{IntechOpen}

(C) 2020 The Author(s). Licensee IntechOpen. This chapter is distributed under the terms of the Creative Commons Attribution License (http://creativecommons.org/licenses/ by/3.0), which permits unrestricted use, distribution, and reproduction in any medium, provided the original work is properly cited. (cc) BY 


\section{References}

[1] Barrett J, Chapman K. The Australian superannuation system. In: Organisation for Economic Co-operation and Development, Private Pensions Systems: Administrative Costs and Reforms. Paris, France: OECD; 2001. pp. 185-200

[2] Chomik R, Piggott J, Woodland AD, Kudrna G, Kumru CS. Means Testing Social Security: Modelling and Policy Analysis. 2015. Available from: http://www.cepar.edu.au/file/502/ download?token=N5onXiVd [Accessed: 11 February 2020]

[3] Department of Social Services. Discussion Paper: Social Security Means Testing of Retirement Income Streams. 2016. Available from: http://www.cepar.edu.au/file/502/ download?token=N5onXiVd [Accessed: 11 February 2020]

[4] Hulse K, Reynolds M, Yates J. Changes in the supply of affordable housing in the private rental sector for lower-income households, 2006-2011. 2014. Final Report No. 235, Australian Housing and Urban Research Institute, Melbourne. Available at: https:// www.ahuri.edu.au/research/finalreports/235 [Accessed: 11 February 2020]

[5] Farnsworth S. Older People at Risk of Homelessness. 2017. Available from: http://mobile.abc.net.au/ news/2017-11-28/older-people-atrisk-of-homelessness-jumps-50pc-innsw/9198420?pfmredir $=$ sm [Accessed: 11 February 2020]

[6] Sane R, Piggott J. Does the OwnerOccupier Exemption from the Pensions Means Test Affect Housing Choice of the Elderly? Evidence from Australia. 2008. Available from: http://wwwdocs. fce.unsw.edu.au/fce/Research/Piggott/ SanePiggott08_residentialchoice.pdf [Accessed: 11 February 2020]
[7] Bradbury B. Asset Rich, but Income Poor: Australian Housing Wealth and Retirement in an International Context. FaHCSIA Social Policy Research Paper. 2010. Available from: https://apo. org.au/sites/default/files/resourcefiles/2010/12/apo-nid23540-1203096. pdf [Accessed: 11 February 2020]

[8] Johnson D, Brimble M, Worthington A. Averting poverty and government budgetary pressure through releasing home equity: A safe and informed solution for baby boomer homeowners. Financial Planning Research Journal. 2016;2(1):55-79. Available from: Averting Poverty and Government Budgetary Pressure Through Releasing Home Equity: A Safe and Informed Solution for Baby Boomer Homeowners [Accessed: 11 February 2020]

[9] Hayward D. The great Australian dream reconsidered: A review of Kemeny. Housing Studies. 1986;1(4):210-219. DOI: $10.1080 / 02673038608720579$

[10] Balnozan I. Slow and Steady: Drawdown Behaviours in Phased Withdrawal Retirement Income Products. 2018. UNSW Business School, Sydney. Available from: https://www. apra.gov.au/sites/default/files/BalnozanModelling-heterogeneous-drawdownbehaviours-in-phased-withdrawalretirement-income-products.pdf [Accessed: 02 February 2020]

[11] ASFA Research and Resource Centre. ASFA Retirement Standard. The Association of Superannuation Funds of Australia. 2019. Available from: https://www.superannuation. asn.au/ArticleDocuments/269/ASFARetirementStandard-Summary-2018. pdf.aspx?Embed $=Y$ [Accessed: 14 February 2020]

[12] Bradshaw J, Finch N. Overlaps in dimensions of poverty. Journal of 
Social Policy. 2003;32(4):513-525. DOI: 10.1017/S004727940300713X

[13] Maeda J. The Laws of Simplicity. Cambridge, Massachusetts: MIT Press; 2006

[14] Asher A, Meyricke R, Thorp S, $\mathrm{Wu}$ S. Age pensioner decumulation: Responses to incentives, uncertainty and family need. Australian Journal of Management. 2017;42(4):583-607

[15] Asher A. Response to Department of Social Services Discussion Paper: Social Security Means Testing of Retirement Income Streams. 2017. Available from: https://engage.dss.gov.au/wp-content/ uploads/2017/03/Discussion-Paperresponse-20170206.pdf [Accessed: 11 February 2020] 


\title{
Pathways to Retirement in Taiwan: Do Ethnicity and Cohort Matter?
}

\author{
Fang-Yi Huang and Monika Ardelt
}

\begin{abstract}
Studies about retirement often neglect ethnic identity. This research utilized the "Taiwan Longitudinal Study in Aging" data from 1989 to 1996 when political and social changes in the country occurred to examine the influence of ethnicity (dominant Mainlanders versus Southern Min, Hakka, and various indigenous people) on Taiwanese men's working status at age 60 and above. We asked three questions:

(1) Are Mainlanders more likely to retire earlier than non-Mainlanders? (2) Does working in the public versus the private sector affect the age of retirement and does this differ by ethnicity? (3) What factors determine retirement ages of two cohorts? Using chi-square and $t$-tests, results of a comparison of two cohorts $(n=1254$ and $n=526$ for the 1989 and 1996 cohorts, respectively) showed that being a Mainlander, being unmarried, older age, self-reported poor health, and functional limitation were associated with a higher likelihood of earlier retirement. In logistic regression models, public sector work mediated and moderated the effect of ethnicity on the likelihood of earlier retirement only in the older cohort, where Mainlander public sector workers had the greatest likelihood of earlier retirement, indicating that the incentive structure of public pensions contributes to earlier retirement. The results are consistent with cumulative advantage theory. To delay the retirement age for public sector workers, policymakers could reduce public pension incentives.
\end{abstract}

Keywords: ethnicity, retirement, pension receipt, cohort, cumulative advantage or disadvantage

\section{Introduction}

The debate of increasing the age for full retirement benefits has centered around the problem of pension deficits but has paid less attention to the outcomes of the policy changes for ethnic groups [1]. Since Taiwan's population is not homogeneous, different groups need to be considered. Southern Min (71\% of Taiwan's total population) and Hakka (12\% of Taiwan's total population) are two groups of people who emigrated from southern Fujian province and Guangdong province of China, respectively, to Taiwan several centuries ago. Indigenous people ( $2 \%$ of Taiwan's total population) are a collection of various indigenous groups who have lived in Taiwan for several hundred years [2]. Mainlanders (15\% of Taiwan's total population) used to be the most powerful group and the ruling party in Taiwan in the 
middle and late twentieth century. Although average life expectancy is increasing in Taiwan [3], not all population groups have benefitted equally with respective consequences for labor force participation. For instance, in 1988, the dominant group of Mainlanders were twice as likely to be employed in Taiwan government or stateowned enterprises than non-Mainlanders, including Southern Min, Hakka, and indigenous people [4, 5], and between 1989 and 2007, Mainlanders experienced comparatively less deterioration in instrumental activities of daily living than nonMainlanders [6]. Mainlanders emigrated from mainland China to Taiwan during the 1940s, when the leader of Kuomintang (KMT), Chiang Kai-shek, fled with millions of people, such as officers, soldiers, and residents, to Taiwan after losing the Chinese civil war. ${ }^{1}$ Mainlanders were also more likely to retire earlier with full pension benefits than non-Mainlanders [7]. Increasing the age for full retirement will therefore reduce the lifetime-expected benefits of disadvantaged groups by a larger percentage if they are forced to take earlier retirement due to disability or health problems than of those who can work in their white-collar jobs until they receive full retirement benefits $[8,9]$. Thus, the current policy postulate to "postpone retirement age to receive the full benefit of pension" hurts disabled minorities who are overrepresented in physically demanding blue-collar jobs more than nonminority white-collar workers $[10,11]$.

Unlike income or education, earlier retirement cannot easily be interpreted as a measure of social inequality [12]. However, retirement, as an exit from a cohesive paid work pattern to pension income, reflects both structural changes and individual experiences, which might represent unequal indicators of retirement. This study aimed to analyze how ethnicity affected and still affects retirement trajectories in Taiwan, contributing not only to cumulative advantage and disadvantage theory (CAD) embedded in the life course paradigm [13-16] but also to policy recommendations for developing countries such as Taiwan in the 1980s.

\section{Ethnicity and retirement}

\subsection{Ethnicity and retirement: in general}

Although a large body of literature on retirement exists, little research has been conducted on ethnic groups. Yet, according to a study of older Americans' labor market participation after retirement age, racial and ethnic inequality plays an important role in retirement decisions [17]. First, individual factors, such as health and socioeconomic status (SES), which are predictors of retirement, are associated with race and ethnicity. For instance, in comparison to the majority group, minorities are less likely to continue working in old age beyond the normal retirement age, because they are more likely to experience poor or fair health, suffer from cognitive impairment, and need help with a larger number of activities of daily living [18-20]. Moreover, members of the minority group are more likely to suffer from disability and to report poor or fair health $[10,17]$, even before reaching normal Social Security retirement age, than members of the majority group [10]. Therefore, minorities experience a substantially higher risk of unemployment and earlier retirement due to activity limitations [21]. Workers with a lower education

\footnotetext{
1 The founding father of the Republic of China, Sun Yat-Sen, created the KMT party and overthrew the empire of the Qing dynasty, the last dynasty in China, through a revolution. However, his successor, Chiang Kai-shek, lost the civil war with Mao Zedong, the founding father of the PRC. Chiang Kai-shek absconded to Taiwan and used violence, the army, and martial law to control Taiwan from 1945 to 1987.
} 
and blue-collar workers often retire earlier than expected because of physical limitations $[12,22]$. Compared to the majority, minorities tend to have a lower education, earn less income, work in physically more demanding jobs, and leave the labor force earlier due to physical constraints in later life [11].

Race or ethnicity determines retirement age due to financial considerations as well. Although members of the majority group tend to be physically able to work longer than the normal retirement age, sufficient income also allows them to retire earlier if they wish [23]. Stable jobs and belonging to a labor union often allow members of the majority group to withdraw from work before the age of 65 . By contrast, members of the disadvantaged minority are more likely to experience involuntary layoffs, low wages, and precarious employment situations without health insurance, private pensions, and labor union coverage, which might force them to work longer to make ends meet [24].

In OECD countries, structural constrains, such as the availability of pension and Social Security retirement income, might either function as incentives to withdraw from work or as motivations to push people out of the labor force [25-28], which further creates retirement inequality between racial groups. For instance, white women tend to gain more from Social Security benefits than black women, because their husbands tend to earn more money and their marriages are more likely to last for ten years or longer, giving them access to the spousal benefit of Social Security [29].

Looking at Western Europe, it is still unknown whether the occupational sector and pension incentives are pushing or pulling factors in retirement. Those who work in the public sector can afford to withdraw from work earlier than those who work in the private sector $[12,30]$. However, the type of employer pension is significantly related to retirement decision-making, and employees whose pension wealth increases with additional work expect to work longer [25]. Hence, minorities with lower socioeconomic status and no access to employer pensions are more likely to claim Social Security benefits earlier compared to members of the majority group who have a higher incentive to delay retirement [31].

In addition, the pension reform can lead to a new retirement pattern. For instance, the private pension structure in the United States has changed from defined benefit (DB) plans to defined contribution (DC) plans [32]. DB plans promise a defined retirement income for the remainder of life after working for an employer for a certain number of years and depending on the length of employment, but they are usually not transferrable from one employer to another and therefore do not benefit mobile workers. DC plans, by contrast, are owned by individual workers. Both employers and employees usually contribute money to the plans, but the employee is solely responsible for investment decisions. Upon retirement, the money in the DC plan is used to finance the worker's retirement. This change from DB to DC plans made the economic environment and the stock market an essential factor for retirement decisions. In particular, the global financial crisis in 2008 forced many people with DC plans to stay in the labor force longer due to the wealth loss in the stock market and the respective decline in DC plans, which tend to invest heavily in the stock market [33].

\subsection{Ethnicity and retirement: in Taiwan}

In Taiwan, the dominant group of Mainlanders has been overrepresented in public sector jobs, particularly during the period of martial law between 1949 and 1989. Native Taiwanese like Southern Min, Hakka, and indigenous people mainly worked in the private sector [34]. The public sector offers greater access to workplace benefits, including defined benefits pension plans, than the private sector. Employer-sponsored retirement plans remain the essential vehicle for distributing 
disproportional retirement income for dominant racial and ethnic groups [35]. For instance, Mainlanders in Taiwan often had tenure in public sector jobs and held managerial or staff positions in most state-owned enterprise [5], which resulted in a steadier employment history, earlier eligibility to claim retirement benefits, and higher retirement benefits through retirement income redistribution.

Admittedly, the literature on how individual and structural factors affect retirement decisions among racial or ethnic groups remains inconclusive. An economic study of retirement decisions in Taiwan found sociodemographic or economic factors might also influence retirement decisions. For instance, studies found that the number of children might influence retirement decisions based on the tradeoffs between investment in children and leisure [36] and married men who are breadwinners are less likely to retire than non-married men [7].

To investigate which factor is the leading force behind earlier retirement, the Taiwanese case with its particular sociopolitical-economic background might help to clarify how ethnic inequality contributes to earlier retirement trajectories. Although Taiwan's public pension system is complicated, it covers zero to four pillars within the World Bank's multi-pillar framework. The usual age of retirement is 60 . The noncontributory "zero or basic pillar" for social welfare programs includes the (i) medium-income elderly living allowance (120 USD per month) and low-income elderly living allowance (233 USD per month), (ii) old-age farmer's welfare allowance (233 USD per month), (iii) veteran home care allowance (472 USD per month), (iv) old-age basic guaranteed pension (117 USD per month), and (v) old-age indigenous welfare allowance pension (117 USD per month) [37]. The first pillar, comprising mandatory public insurance programs, works as a DB plan. The insurance programs are based on occupation. Labor Insurance (LI), Old-age Farmer Welfare Allowance (OAF), and Government Employee Insurance (GEI) were three main occupational insurance systems between 1950 and 1990, in addition to welfare assistance provided to a small group of the elderly, the Veteran Homecare Allowance (VHA) [38]. The National Pension Program, enacted in 2009, also belongs to the first pillar [37]. The second pillar contains the labor pension plan, private school pension plan, and Public Service Pension Fund (PSPF). The PSPF covers political appointees, civil servants, public school teachers, and military personnel [37]. The third pillar comprises voluntary pension programs, such as individual savings. Finally, the fourth pillar is an informal support system, such as family and intergenerational support for the elderly.

In Taiwan, ethnicity is regarded as one social inequality indicator [39, 40]. The ethnic group Chinese Mainlander, who emigrated from China to Taiwan in the 1940s during the Chinese civil war and became the ruling class in Taiwan, has a different retirement trajectory than the native Southern Min, Hakka, and indigenous people. Hung found that Mainlanders had a higher likelihood of early retirement than Southern Min [7], but Hung failed to explain why Mainlanders who tend to have a higher income and education chose to retire earlier. Since Mainlanders were the ruling class under the societal conditions of economic hardship and martial law (1940s-1989), the theory of cumulative advantage across the life course could explain how socioeconomic status shaped the dissimilar retirement trajectories among Mainlanders and non-Mainlanders.

We propose three hypotheses:

H1: Mainlanders were more likely to retire earlier than non-Mainlanders.

$\mathrm{H} 2$ : After controlling for public sector employment, the effect of ethnicity on the likelihood of retirement will decrease significantly in the older cohort, born between 1924 and 1929, but not in the younger cohort, born between 1931 and 1936. 
H3: In the older cohort, Mainlander public sector workers were more likely to retire earlier than Mainlander non-public sector workers.

Taiwan is a patriarchic society. Female labor force participation rates were $35.81 \%, 39.25 \%, 45.35 \%, 46.02 \%$, and $50.92 \%$ in $1961,1980,1989,2000$, and 2017 , respectively, compared to $86.37 \%, 77.11 \%, 74.84 \%, 69.42 \%$, and $67.13 \%$ for men $[41,42]$. Although women's labor force participation rates have steadily increased, men overwhelmingly tend to be the breadwinner. Since our dataset contained only few female respondents with work experience, we focused our analysis on men only.

\section{Method}

This study takes a quantitative approach and uses the Taiwan Longitudinal Study in Aging (TLSA) from 1989 and 1996. TLSA is a nationwide longitudinal household interview survey, which began in 1989 by the Health Promotion Administration, Taiwan Ministry of Health and Welfare, to monitor the health and economic changes of the Taiwan population aged 60 and above. The sampling plan adopted a three-stage probability design with stratified random sampling. In the first stage, representative cities or towns were chosen randomly. In the second stage, the authorities chose the representative villages randomly from the representative cities or towns. In the last stage, two representative respondents age 60 or above were randomly chosen from each representative village among all households and noninstitutional group residences. All surveys were conducted through face-toface interviews.

A total of 4049 adults, aged 60-103 years, participated in the first 1989 wave of Panel A. The same individuals were contacted in 1993 and 1996. In 1996, 1599 new respondents, aged 50-70, were added to the TLSA, comprising one more additional Panel B. The number of observations for Panel A decreased from 4049 in 1989 to 3155 in 1993 and 2669 in 1996 with response rates of 91.8\%, 91.1\%, and 88.9\%, respectively. For Panel B in 1996, the response rate was $81.2 \%$. This study analyzed members of the TLSA male sample who were 60-87 years old in Panel A in 1989 and 60-70 years old in Panel B in 1996 and had valid values on all study variables, resulting in 1254 and 526 men for Panel A and Panel B, respectively.

The outcome variable is whether the respondent worked or not. We coded respondents who did not work as the retired group (coded as 0 ) and those who were still working as the working group (coded as 1). The core independent variable is ethnic identity, which is a categorical variable in the first wave with four categories: Southern Min, Hakka, indigenous people, and Mainlander. Ethnic identity was recoded as Mainlander $=1$ and non-Mainlander $=0$.

Additional variables are cohort, demographics, socioeconomic status, and health. Cohort indicates two panels with data derived from the 1989 wave, 1993 wave, and 1996 wave as the older cohort (Panel A) and from 1996 as the younger cohort (Panel B). Age was measured in years and ranges from 60 to 87 years for the older cohort and from 60 to 70 for the younger cohort. Marital status is a binary variable, assessed as married (1) and not married (0) in each wave.

Socioeconomic status contains three indicators: education, occupational category, and occupational sector. Education is assessed as years of schooling, ranging from 0 to 17. The variable "occupation" originally had 99 occupational classifications. For simplification, only two classifications were used: Occupations that are not related to physical labor were coded as "white-collar work" (1) and all others as "non-white-collar work" (0). "Occupational sector" distinguishes between "public 
Who Wants to Retire and Who Can Afford to Retire?

\begin{tabular}{lcccc}
\hline & 1989 Panel A & 1993 Panel A & 1996 Panel A & 1996 Panel B \\
\hline Still working & $619(49.36 \%)$ & $412(32.85 \%)$ & $247(19.70 \%)$ & $255(48.48 \%)$ \\
\hline Mainlander & $409(32.62 \%)$ & $409(32.62 \%)$ & $409(32.62 \%)$ & $123(23.38 \%)$ \\
\hline Age & $65.72(4.95)$ & $70.44(4.88)$ & $73.44(4.88)$ & $63.51(2.34)$ \\
\hline Married & $1040(82.93 \%)$ & $960(76.56 \%)$ & $903(72.01 \%)$ & $429(81.56 \%)$ \\
\hline Education & $5.74(4.70)$ & $5.74(4.70)$ & $5.74(4.70)$ & $6.34(4.17)$ \\
\hline White collar & $270(21.53 \%)$ & $270(21.53 \%)$ & $270(21.53 \%)$ & $180(34.22 \%)$ \\
\hline Public sector & $181(14.43 \%)$ & $181(14.43 \%)$ & $181(14.43 \%)$ & $130(24.71 \%)$ \\
\hline Self-reported poor health & $2.35(1.01)$ & $2.39(1.08)$ & $2.79(1.10)$ & $2.73(1.11)$ \\
\hline Functional limitation & $217(17.30 \%)$ & $352(27.99 \%)$ & $403(32.14 \%)$ & $93(17.68 \%)$ \\
\hline
\end{tabular}

Note: 1. Frequencies (percentages) are shown for variables "still working, married, white collar, public sector, and functional limitation." The mean (standard deviation) are shown for variables "age, education years, and selfreported poor health"; 2. The datasets only include male respondents; 3. Age ranges from 60 to 87 years for panel $A$ and from 60 to 70 years for Panel $B$.

Table 1.

Descriptive analysis.

\begin{tabular}{|c|c|c|c|c|c|c|c|c|}
\hline $\begin{array}{l}\text { Year } \\
\text { Percentage still } \\
\text { working }\end{array}$ & $\begin{array}{c}1989 \\
\text { Panel A }\end{array}$ & $\begin{array}{l}\chi^{2} \\
(p)\end{array}$ & $\begin{array}{c}1993 \\
\text { Panel A }\end{array}$ & $\begin{array}{l}\chi^{2} \\
(\mathrm{p})\end{array}$ & $\begin{array}{c}1996 \\
\text { Panel A }\end{array}$ & $\begin{array}{l}\chi^{2} \\
(\mathrm{p})\end{array}$ & $\begin{array}{c}1996 \\
\text { Panel B }\end{array}$ & $\begin{array}{l}\chi^{2} \\
(\mathbf{p})\end{array}$ \\
\hline Still working & $49.36 \%$ & & $32.85 \%$ & & $19.70 \%$ & & $48.48 \%$ & \\
\hline \multicolumn{9}{|l|}{ Ethnicity } \\
\hline Mainlander & $47.19 \%$ & \multirow{2}{*}{$\begin{array}{c}1.15 \\
(0.284)\end{array}$} & $27.38 \%$ & \multirow{2}{*}{$\begin{array}{c}8.24 \\
(0.004)\end{array}$} & $18.34 \%$ & \multirow{2}{*}{$\begin{array}{c}0.71 \\
(0.400)\end{array}$} & $40.65 \%$ & \multirow{2}{*}{$\begin{array}{c}3.94 \\
(0.047)\end{array}$} \\
\hline Non-Mainlander & $50.41 \%$ & & $35.50 \%$ & & $20.36 \%$ & & $50.87 \%$ & \\
\hline \multicolumn{9}{|l|}{ Marital status } \\
\hline Not married & $41.59 \%$ & \multirow{2}{*}{$\begin{array}{c}6.24 \\
(0.013)\end{array}$} & $25.51 \%$ & \multirow{2}{*}{$\begin{array}{c}9.39 \\
(0.002)\end{array}$} & $13.39 \%$ & \multirow{2}{*}{$\begin{array}{c}12.26 \\
(0.000)\end{array}$} & $35.05 \%$ & \multirow{2}{*}{$\begin{array}{c}8.59 \\
(0.003)\end{array}$} \\
\hline Married & $50.96 \%$ & & $35.10 \%$ & & $22.15 \%$ & & $51.52 \%$ & \\
\hline \multicolumn{9}{|c|}{ Occupational category } \\
\hline Non-white-collar & $48.78 \%$ & \multirow{2}{*}{$\begin{array}{c}0.62 \\
(0.432)\end{array}$} & $34.45 \%$ & \multirow{2}{*}{$\begin{array}{c}5.28 \\
(0.022)\end{array}$} & $20.43 \%$ & \multirow{2}{*}{$\begin{array}{c}1.54 \\
(0.215)\end{array}$} & $51.73 \%$ & \multirow{2}{*}{$\begin{array}{c}4.29 \\
(0.038)\end{array}$} \\
\hline White collar & $51.48 \%$ & & $27.04 \%$ & & $17.04 \%$ & & $42.22 \%$ & \\
\hline \multicolumn{9}{|l|}{ Occupational sector } \\
\hline Private sector & $52.66 \%$ & \multirow{2}{*}{$\begin{array}{c}32.27 \\
(0.000)\end{array}$} & $36.81 \%$ & \multirow{2}{*}{$\begin{array}{c}27.94 \\
(0.000)\end{array}$} & $21.62 \%$ & \multirow{2}{*}{$\begin{array}{c}12.77 \\
(0.000)\end{array}$} & $50.00 \%$ & \multirow{2}{*}{$\begin{array}{c}1.48 \\
(0.223)\end{array}$} \\
\hline Public sector & $29.83 \%$ & & $9.39 \%$ & & $8.29 \%$ & & $43.85 \%$ & \\
\hline \multicolumn{9}{|c|}{ Functional limitation } \\
\hline No & $52.84 \%$ & \multirow{2}{*}{$\begin{array}{c}29.08 \\
(0.000)\end{array}$} & $39.20 \%$ & \multirow{2}{*}{$\begin{array}{c}58.93 \\
(0.000)\end{array}$} & $24.68 \%$ & \multirow{2}{*}{$\begin{array}{c}41.52 \\
(0.000)\end{array}$} & $53.58 \%$ & \multirow{2}{*}{$\begin{array}{c}25.51 \\
(0.000)\end{array}$} \\
\hline Yes & $32.72 \%$ & & $16.52 \%$ & & $9.18 \%$ & & $24.73 \%$ & \\
\hline Number working & 619 & & 412 & & 247 & & 225 & \\
\hline
\end{tabular}

Notes: 1 . The total number of cases is 1254 for Panel $A$ and 526 for Panel B; 2. The datasets only include male respondents; 3. Age ranges from 60 to 87 years for panel $A$ and from 60 to 70 years for Panel B; 4 . Bold style indicates statistical significance at $\mathrm{p}<0.05$.

Table 2.

Comparison of work and retired groups by demographics: chi-square tests. 
Pathways to Retirement in Taiwan: Do Ethnicity and Cohort Matter?

DOI: http://dx.doi.org/10.5772/intechopen.92147

\begin{tabular}{|c|c|c|c|c|}
\hline Dependent variable & Still working & Retired & t-test & $P$ value \\
\hline & M (SD) & M (SD) & & \\
\hline \multicolumn{5}{|l|}{1989 Panel A } \\
\hline Age & $64.50(4.22)$ & $66.91(5.31)$ & 8.89 & 0.000 \\
\hline Education & $5.91(4.77)$ & $5.58(4.63)$ & -1.27 & 0.203 \\
\hline Self-reported poor health & $2.26(0.94)$ & $2.44(1.07)$ & 2.33 & 0.001 \\
\hline \multicolumn{5}{|l|}{1993 Panel A } \\
\hline Age & $69.07(2.89)$ & $71.12(5.16)$ & 7.83 & 0.000 \\
\hline Education & $5.28(4.40)$ & $5.97(4.82)$ & 2.52 & 0.012 \\
\hline Self-reported poor health & $2.26(2.16)$ & $2.46(2.39)$ & 3.18 & 0.002 \\
\hline \multicolumn{5}{|l|}{1996 Panel A } \\
\hline Age & 71.75 (3.77) & $73.86(5.03)$ & 7.33 & 0.000 \\
\hline Education & $5.72(4.44)$ & $5.75(4.76)$ & 0.10 & 0.918 \\
\hline Self-reported poor health & $2.40(1.05)$ & $2.89(1.10)$ & 6.46 & 0.000 \\
\hline \multicolumn{5}{|l|}{1996 Panel B } \\
\hline Age & $62.99(2.24)$ & $64.00(2.34)$ & 5.07 & 0.000 \\
\hline Education & $6.59(4.20)$ & $6.11(4.13)$ & -1.33 & 0.186 \\
\hline Self-reported poor health & $2.40(1.00)$ & $3.04(1.12)$ & 6.90 & 0.000 \\
\hline
\end{tabular}

Notes: 1. The total number of cases is 1254 for Panel $A$ and 526 for Panel B; 2. The datasets only include male respondents; 3. Age ranges from 60 to 87 years for panel $A$ and from 60 to 70 years for Panel B; 4. Bold style indicates statistical significance at $\mathrm{p}<0.05$.

Table 3.

Comparison of work and retired groups by demographics: $t$-tests.

\begin{tabular}{|c|c|c|c|c|c|c|c|c|}
\hline Model & $\begin{array}{c}1989 \\
\text { Panel A } \\
\text { Model } 1\end{array}$ & $\begin{array}{c}1989 \\
\text { Panel A } \\
\text { Model } 2\end{array}$ & $\begin{array}{c}1989 \\
\text { Panel A } \\
\text { Model } 3\end{array}$ & $\begin{array}{c}1989 \\
\text { Panel A } \\
\text { Model } 4\end{array}$ & $\begin{array}{c}1996 \\
\text { Panel B } \\
\text { Model } 1\end{array}$ & $\begin{array}{c}1996 \\
\text { Panel B } \\
\text { Model } 2\end{array}$ & $\begin{array}{c}1996 \\
\text { Panel B } \\
\text { Model } 3\end{array}$ & $\begin{array}{c}1996 \\
\text { Panel B } \\
\text { Model } 4\end{array}$ \\
\hline \multicolumn{9}{|l|}{ Ethnicity } \\
\hline Mainlander & $\begin{array}{c}0.798^{*} \\
(0.624- \\
1.020)\end{array}$ & $\begin{array}{c}0.817 \\
(0.631- \\
1.056)\end{array}$ & $\begin{array}{c}1.009 \\
(0.770- \\
1.322)\end{array}$ & $\begin{array}{c}1.163 \\
(0.868- \\
1.557)\end{array}$ & $\begin{array}{c}1.106 \\
(0.697- \\
1.755)\end{array}$ & $\begin{array}{c}1.020 \\
(0.614- \\
1.696)\end{array}$ & $\begin{array}{c}1.130 \\
(0.631- \\
2.022)\end{array}$ & $\begin{array}{c}0.966 \\
(0.442- \\
2.114)\end{array}$ \\
\hline \multicolumn{9}{|c|}{ Control factors } \\
\hline Age & $\begin{array}{l}0.897^{* * *} \\
(0.874- \\
0.920)\end{array}$ & $\begin{array}{l}0.901^{* * *} \\
(0.877- \\
0.925)\end{array}$ & $\begin{array}{l}0.895^{* * *} \\
(0.871- \\
0.920)\end{array}$ & $\begin{array}{l}0.897^{* * *} \\
(0.871- \\
0.920)\end{array}$ & $\begin{array}{l}0.823^{* * *} \\
(0.757- \\
0.895)\end{array}$ & $\begin{array}{l}0.824^{* * *} \\
(0.754- \\
0.900)\end{array}$ & $\begin{array}{l}0.825^{* * *} \\
(0.755- \\
0.901)\end{array}$ & $\begin{array}{l}0.824^{* * *} \\
(0.754- \\
0.900)\end{array}$ \\
\hline Married & $\begin{array}{c}1.238 \\
(0.907- \\
1.689)\end{array}$ & $\begin{array}{c}1.243 \\
(0.906- \\
1.706)\end{array}$ & $\begin{array}{c}1.174 \\
(0.849- \\
1.623)\end{array}$ & $\begin{array}{c}1.162 \\
(0.839- \\
1.608)\end{array}$ & $\begin{array}{l}1.938^{* * *} \\
(1.205- \\
3.115)\end{array}$ & $\begin{array}{l}1.849^{* *} \\
(1.119- \\
3.056)\end{array}$ & $\begin{array}{l}1.886^{* *} \\
(1.137- \\
3.129)\end{array}$ & $\begin{array}{l}1.879^{* *} \\
(1.133- \\
3.118)\end{array}$ \\
\hline \multicolumn{9}{|c|}{ Individual factors } \\
\hline Education & & $\begin{array}{c}0.995 \\
(0.965- \\
1.025)\end{array}$ & $\begin{array}{c}1.011 \\
(0.980- \\
1.042)\end{array}$ & $\begin{array}{c}1.010 \\
(0.979- \\
1.041)\end{array}$ & & $\begin{array}{c}1.032 \\
(0.981- \\
1.086)\end{array}$ & $\begin{array}{c}1.037 \\
(0.984- \\
1.092)\end{array}$ & $\begin{array}{c}1.039 \\
(0.986- \\
1.095)\end{array}$ \\
\hline $\begin{array}{l}\text { White } \\
\text { collar }\end{array}$ & & $\begin{array}{c}1.031 \\
(0.742- \\
1.432)\end{array}$ & $\begin{array}{c}1.385 \\
(0.974- \\
1.968)\end{array}$ & $\begin{array}{c}1.349 \\
(0.948- \\
1.920)\end{array}$ & & $\begin{array}{c}0.616^{* *} \\
(0.393- \\
0.965)\end{array}$ & $\begin{array}{c}0.640 \\
(0.403- \\
1.015)\end{array}$ & $\begin{array}{c}0.644 \\
(0.406- \\
1.023)\end{array}$ \\
\hline $\begin{array}{l}\text { Self- } \\
\text { reported } \\
\text { poor health }\end{array}$ & & $\begin{array}{c}0.885 \\
(0.783- \\
1.002)\end{array}$ & $\begin{array}{l}0.876^{* *} \\
(0.773- \\
0.994)\end{array}$ & $\begin{array}{l}0.879^{* *} \\
(0.775- \\
0.997)\end{array}$ & & $\begin{array}{l}0.623^{* * *} \\
(0.511- \\
0.759)\end{array}$ & $\begin{array}{l}0.621^{* * *} \\
(0.509- \\
0.757)\end{array}$ & $\begin{array}{c}0.620^{* * *} \\
(0.508- \\
0.755)\end{array}$ \\
\hline
\end{tabular}


Who Wants to Retire and Who Can Afford to Retire?

\begin{tabular}{|c|c|c|c|c|c|c|c|c|}
\hline Model & $\begin{array}{c}1989 \\
\text { Panel A } \\
\text { Model } 1\end{array}$ & $\begin{array}{c}1989 \\
\text { Panel A } \\
\text { Model } 2\end{array}$ & $\begin{array}{c}1989 \\
\text { Panel A } \\
\text { Model } 3\end{array}$ & $\begin{array}{c}1989 \\
\text { Panel A } \\
\text { Model } 4\end{array}$ & $\begin{array}{c}1996 \\
\text { Panel B } \\
\text { Model } 1\end{array}$ & $\begin{array}{c}1996 \\
\text { Panel B } \\
\text { Model } 2\end{array}$ & $\begin{array}{c}1996 \\
\text { Panel B } \\
\text { Model } 3\end{array}$ & $\begin{array}{c}1996 \\
\text { Panel B } \\
\text { Model } 4\end{array}$ \\
\hline $\begin{array}{l}\text { Functional } \\
\text { limitation }\end{array}$ & & $\begin{array}{c}0.566^{* * *} \\
(0.404- \\
0.795)\end{array}$ & $\begin{array}{l}0.5666^{* * *} \\
(0.401- \\
0.799)\end{array}$ & $\begin{array}{l}0.567^{* * *} \\
(0.401- \\
0.802)\end{array}$ & & $\begin{array}{c}0.516^{* *} \\
(0.289- \\
0.920)\end{array}$ & $\begin{array}{l}0.512^{* *} \\
(0.287- \\
0.913)\end{array}$ & $\begin{array}{l}0.510^{* *} \\
(0.286- \\
0.909)\end{array}$ \\
\hline \multicolumn{9}{|c|}{ Structural factors } \\
\hline $\begin{array}{l}\text { Public } \\
\text { sector }\end{array}$ & & & $\begin{array}{l}0.254^{* * *} \\
(0.170- \\
0.380)\end{array}$ & $\begin{array}{l}0.448^{* * *} \\
(0.249- \\
0.805)\end{array}$ & & & $\begin{array}{c}0.809 \\
(0.450- \\
1.457)\end{array}$ & $\begin{array}{c}0.703 \\
(0.332- \\
1.489)\end{array}$ \\
\hline $\begin{array}{l}\text { Interaction } \\
\text { sector*main }\end{array}$ & $\begin{array}{l}\text { rm: Public } \\
\text { nder }\end{array}$ & & & $\begin{array}{l}0.386^{* *} \\
(0.183- \\
0.814)\end{array}$ & & & & $\begin{array}{c}1.396 \\
(0.460- \\
4.230)\end{array}$ \\
\hline
\end{tabular}

Notes: 1. The total number of cases is 1254 for Panel A and 526 for Panel B; 2. The datasets only include male respondents; 3. Age ranges from 60 to 87 years for panel $A$ and from 60 to 70 years for Panel B; 4 . Odds ratios with $95 \%$ confidence intervals in parentheses. ${ }^{* * *} p<0.01,{ }^{* *} p<0.05,{ }^{*} p<0.1$

Table 4 .

Logistic regression models for the probability of working in 1989 for Panel $A$ and in 1996 for Panel B.

\begin{tabular}{|c|c|c|c|c|c|c|c|c|}
\hline Model & $\begin{array}{c}1993 \\
\text { Panel A } \\
\text { Model 1 }\end{array}$ & $\begin{array}{c}1993 \\
\text { Panel A } \\
\text { Model } 2\end{array}$ & $\begin{array}{c}1993 \\
\text { Panel A } \\
\text { Model } 3\end{array}$ & $\begin{array}{c}1993 \\
\text { Panel A } \\
\text { Model } 4\end{array}$ & $\begin{array}{c}1996 \\
\text { Panel A } \\
\text { Model 1 }\end{array}$ & $\begin{array}{c}1996 \\
\text { Panel A } \\
\text { Model } 2\end{array}$ & $\begin{array}{c}1996 \\
\text { Panel A } \\
\text { Model } 3\end{array}$ & $\begin{array}{c}1996 \\
\text { Panel A } \\
\text { Model } 3\end{array}$ \\
\hline \multicolumn{9}{|l|}{ Ethnicity } \\
\hline Mainlander & $\begin{array}{l}0.643^{* * *} \\
(0.492- \\
0.841)\end{array}$ & $\begin{array}{c}0.691^{* *} \\
(0.520- \\
0.917)\end{array}$ & $\begin{array}{c}0.866 \\
(0.645- \\
1.164)\end{array}$ & $\begin{array}{c}0.836 \\
(0.615- \\
1.136)\end{array}$ & $\begin{array}{c}0.842 \\
(0.618- \\
1.145)\end{array}$ & $\begin{array}{c}0.851 \\
(0.615- \\
1.179)\end{array}$ & $\begin{array}{l}1.007 \\
(0.721- \\
1.406)\end{array}$ & $\begin{array}{c}1.074 \\
(0.760- \\
1.518)\end{array}$ \\
\hline \multicolumn{9}{|c|}{ Control factors } \\
\hline Age & $\begin{array}{l}0.903^{* * *} \\
(0.877- \\
0.930)\end{array}$ & $\begin{array}{l}0.907^{* * *} \\
(0.880- \\
0.935)\end{array}$ & $\begin{array}{l}0.902^{* * *} \\
(0.875- \\
0.931)\end{array}$ & $\begin{array}{l}0.902^{* * *} \\
(0.874- \\
0.931)\end{array}$ & $\begin{array}{l}0.898^{* * *} \\
(0.866- \\
0.932)\end{array}$ & $\begin{array}{l}0.906^{* * *} \\
(0.872- \\
0.941)\end{array}$ & $\begin{array}{l}0.903^{* * *} \\
(0.869- \\
0.938)\end{array}$ & $\begin{array}{l}0.903^{* * *} \\
(0.869- \\
0.938)\end{array}$ \\
\hline Married & $\begin{array}{c}1.309 \\
(0.965- \\
1.776)\end{array}$ & $\begin{array}{l}1.452^{* *} \\
(1.058- \\
1.993)\end{array}$ & $\begin{array}{l}1.416^{* *} \\
(1.026- \\
1.954)\end{array}$ & $\begin{array}{l}1.420^{* *} \\
(1.029- \\
1.958)\end{array}$ & $\begin{array}{l}1.581^{* *} \\
(1.111- \\
2.249)\end{array}$ & $\begin{array}{l}1.679^{* * *} \\
(1.165- \\
2.418)\end{array}$ & $\begin{array}{l}1.627^{* * *} \\
(1.127- \\
2.348)\end{array}$ & $\begin{array}{l}1.623^{* * *} \\
(1.124- \\
2.344)\end{array}$ \\
\hline Education & & $\begin{array}{l}0.954^{* * *} \\
(0.924- \\
0.986)\end{array}$ & $\begin{array}{c}0.970 \\
(0.937- \\
1.004)\end{array}$ & $\begin{array}{c}0.970 \\
(0.938- \\
1.004)\end{array}$ & & $\begin{array}{c}0.973 \\
(0.936- \\
1.011)\end{array}$ & $\begin{array}{c}0.985 \\
(0.947- \\
1.024)\end{array}$ & $\begin{array}{c}0.985 \\
(0.947- \\
1.024)\end{array}$ \\
\hline $\begin{array}{l}\text { White } \\
\text { collar }\end{array}$ & & $\begin{array}{c}0.778 \\
(0.542- \\
1.116)\end{array}$ & $\begin{array}{c}1.058 \\
(0.720- \\
1.555)\end{array}$ & $\begin{array}{c}1.069 \\
(0.727- \\
1.571)\end{array}$ & & $\begin{array}{c}0.702 \\
(0.459- \\
1.073)\end{array}$ & $\begin{array}{c}0.869 \\
(0.560- \\
1.351)\end{array}$ & $\begin{array}{c}0.848 \\
(0.544- \\
1.323)\end{array}$ \\
\hline $\begin{array}{l}\text { Self- } \\
\text { reported } \\
\text { poor health }\end{array}$ & & $\begin{array}{c}0.928 \\
(0.817- \\
1.054)\end{array}$ & $\begin{array}{c}0.943 \\
(0.827- \\
1.074)\end{array}$ & $\begin{array}{c}0.944 \\
(0.828- \\
1.076)\end{array}$ & & $\begin{array}{l}0.727^{* * *} \\
(0.629- \\
0.842)\end{array}$ & $\begin{array}{l}0.721^{* * *} \\
(0.623- \\
0.836)\end{array}$ & $\begin{array}{l}0.719^{* * *} \\
(0.620- \\
0.833)\end{array}$ \\
\hline $\begin{array}{l}\text { Functional } \\
\text { limitation }\end{array}$ & & $\begin{array}{l}0.338^{* * *} \\
(0.239- \\
0.477)\end{array}$ & $\begin{array}{l}0.325^{* * *} \\
(0.229- \\
0.460)\end{array}$ & $\begin{array}{l}0.324^{* * *} \\
(0.228- \\
0.459)\end{array}$ & & $\begin{array}{l}0.415^{* * *} \\
(0.278- \\
0.619)\end{array}$ & $\begin{array}{l}0.416^{* * *} \\
(0.279- \\
0.621)\end{array}$ & $\begin{array}{l}0.416^{* * *} \\
(0.278- \\
0.620)\end{array}$ \\
\hline \multicolumn{9}{|c|}{ Structural factors } \\
\hline $\begin{array}{l}\text { Public } \\
\text { sector }\end{array}$ & & & $\begin{array}{c}0.162^{* * *} \\
(0.0928- \\
0.282)\end{array}$ & $\begin{array}{c}0.117^{* * *} \\
(0.0446- \\
0.306)\end{array}$ & & & $\begin{array}{l}0.278^{* * *} \\
(0.153- \\
0.508)\end{array}$ & $\begin{array}{c}0.437 \\
(0.184- \\
1.036)\end{array}$ \\
\hline
\end{tabular}


Pathways to Retirement in Taiwan: Do Ethnicity and Cohort Matter?

DOI: http://dx.doi.org/10.5772/intechopen.92147

\begin{tabular}{lcccccccc}
\hline Model & 1993 & 1993 & 1993 & 1993 & 1996 & 1996 & 1996 & 1996 \\
& Panel A & Panel A & $\begin{array}{c}\text { Panel A } \\
\text { Model 1 }\end{array}$ & $\begin{array}{c}\text { Panel A } \\
\text { Model 2 }\end{array}$ & $\begin{array}{c}\text { Podel 3 } \\
\text { Model 4 }\end{array}$ & $\begin{array}{c}\text { Model 1 } \\
\text { Panel A } \\
\text { Model 2 }\end{array}$ & $\begin{array}{c}\text { Panel A } \\
\text { Model 3 }\end{array}$ & $\begin{array}{c}\text { Panel A } \\
\text { Model 3 }\end{array}$ \\
\hline Interaction term: public & & & 1.656 & & & & 0.470 \\
sector*mainlander & & & $(0.524-$ & & & $(0.149-$ \\
& & & $5.228)$ & & & $1.480)$ \\
\hline
\end{tabular}

Notes: 1 . The total number of cases is 1254 for Panel A; 2. The dataset only includes male respondents; 3 . Age ranges from 64 to 91 years for the 1993 wave of Panel $A$ and from 67 to 94 years for the 1996 wave of Panel A. The data includes all men from Panel A who participated in 1989, 1993, and 1996; 4. Odds ratios with $95 \%$ confidence intervals in parentheses: ${ }^{* * *} p<0.01$, ${ }^{* *} p<0.05,{ }^{*} p<0.1$

Table 5 .

Logistic regression models for the probability of working for in 1993 and in 1996 for Panel A.

sector work" (1), defined as working for the government or various government bodies, and nongovernment or "private sector work" (0).

Health consists of self-reported health and functional limitation. Self-reported poor health was measured by the following items: 1 = very good health, 2 = good health, 3 = fair health, 4 = poor health, and $5=$ very poor health. Functional limitation was measured by the eight-item scale of advanced physical functions. Respondents were asked how difficult ( 0 = no difficulty, 1 = some difficulty, 2 = very difficult, 3 = cannot do it at all) it would be for them to (1) stand for $15 \mathrm{~min}$, (2) squat without anyone's help, (3) raise both hands over their head, (4) grasp or twist objects, (5) lift or carry $12 \mathrm{~kg}$, (6) run for 20 or $30 \mathrm{~m}$, (7) walk for 200 or 300 $\mathrm{m}$, and (8) climb 2 or 3 flights of stairs. Respondents who mentioned any functional limitation were coded as 1 , and all others were coded as 0 .

We used descriptive analysis (Table 1 ) to describe the samples and $\chi^{2}$ tests (Table 2) and $t$-tests (Table 3) to investigate demographic differences between the work group and the retired group. Finally, we applied multivariate logit models in Tables 4 and 5 to analyze the relative contribution of the independent variables on the likelihood of still working and whether the interaction between Mainlander and working in the public sector is significant.

All the analyses were conducted by STATA 14 and incorporated the weighted procedure used in TLSA sampling design.

\section{Data collection and results}

Table 1 contains the descriptive analysis for both cohorts. Frequency and percentages are shown for "still working," "marital status," "occupation category," "occupation sector," and "functional limitation." Means and standard deviations are shown for "age," "education," and "self-reported poor health." In Panel A, 49.36\% of the men were still working in 1989, which declined to $32.85 \%$ in 1993 and $19.70 \%$ in 1996. In Panel B, 48.48\% of the men were still working in 1996 . Only $32.62 \%$ and 23.38\% were Mainlanders among the 1989 and 1996 panelists, respectively. The mean age was 65.72 years $(S D=4.95)$ in 1989 for Panel $A$ and 63.51 years $(S D=$ 2.34) in 1996 for Panel B. In Panel A, the proportions of married men changed from $82.93 \%$ in 1989 to $76.56 \%$ in 1993 and $72.01 \%$ in 1996 . In Panel B, 81.5\% of the men were married in 1996. Mean education years were 5.74 and 6.34 for Panel A and B, respectively. In Panel A, 21.53\% of the men were white-collar workers and $14.43 \%$ worked in the public sector, compared to $34.22 \%$ of white-collar workers and $24.71 \%$ of public sector workers in Panel B. For Panel A, means of self-reported poor 
health increased from $2.35(S D=1.01)$ in 1989 to $2.39(S D=1.08)$ in 1993 and 2.79 $(S D=1.10)$ in 1996 , compared to $2.73(S D=1.11)$ for Panel B in 1996. Similarly, the proportions of men with functional limitation increased from $17.30 \%$ in 1989 to $27.99 \%$ in 1993 and $32.14 \%$ in 1996 for Panel A, compared to $17.68 \%$ for Panel B in 1996.

Table 2 shows the results of the chi-square tests. Compared to retired men, men who were still working were more likely to be married and without functional limitations in all waves. Non-Mainlanders, such as Southern Min, and non-whitecollar workers were more likely to be working in 1993 for Panel A and in 1996 for Panel B. In Panel A but not Panel B, a higher proportion of private sector workers was still working from 1989 to 1996 . To be specific, $52.66 \%, 36.81 \%$, and $21.62 \%$ of private sector workers still worked in 1989, 1993, and 1996, respectively, in Panel A compared to $29.83 \%, 9.39 \%$, and $8.29 \%$ of public sector workers.

Table 3 compares the means of the still working and retired groups of men for "age," "education," and "self-reported poor health," using $t$-tests. The retired group tended to be older and in worse health for both panels and in all years. On average, retirees were 66.91 and 64.00 years old in 1989 in Panel A and in 1996 in Panel B, respectively, whereas men who were still working were 64.50 years old in Panel A and 62.99 years old in Panel B. Additionally, the average scores of self-reported poor health for retirees were 2.44, 2.46, 2.89, and 3.04 in 1989, 1993, and 1996 for Panel A and 1996 for Panel B, respectively, which were significantly higher than the respective average scores of 2.26, 2.26, 2.40, and 2.40 for those men who were still working. However, education was unrelated to working status, except in 1993 for Panel A when the average years of education was 5.97 for retired men, which was significantly higher than the average years of education of 5.28 for men who were still working.

Table 4 compares the results between Panel A and B when the men were of similar ages, using nested logistic regression models. The left side of the table estimates the probability of men still working in 1989. In Model 1, Mainlanders were $20.2 \%$ less likely to work at age 60 and above than non-Mainlanders after controlling for age and marital status. As predicted by Hypothesis 2, the effect of ethnicity on the likelihood of still working became nonsignificant after controlling for socioeconomic status and health condition in Model 2 and adding occupational sector in Model 3. Each age year decreased the odds of still working. Marital status, education, and occupational category were unrelated to the likelihood of working. In Model 3, a one-unit increase in self-reported poor health was associated with a $12.4 \%$ less likelihood of working. Men with a functional limitation and public sector workers were $43.4 \%$ and $74.6 \%$, respectively, less likely to be still working. In Model 4, the interaction between public sector worker and Mainlander was significant. As predicted by Hypothesis 3, Mainlanders who worked in the public sector had much greater odds of being retired. They were $61.4 \%$ less likely of being in the labor force than other men, which might explain the earlier retirement of Mainlanders.

The right side of Table 4 shows the odds ratios of still working among the younger cohort of Panel B. Being a Mainlander, public sector worker, and education were not associated with earlier retirement in all models. The interaction between public sector worker and Mainlander was also not significant in Model 4. In Model 4 , each age year decreased the odds of still working by $17.6 \%$, and married men had a 1.879 times higher probability of still working than non-married men at age 60 and above. Additionally, a one-unit increase in self-reported poor health was associated with a $38 \%$ lower likelihood of still working. Men with a functional limitation were $49 \%$ less likely to be still working, indicating that those with worse health conditions were more likely to retire than healthier men. 
Table 4 shows that members of Panel A and B had different odds of retirement related to being a Mainlander, marital status, and occupational sector. The results suggest that marital status plays a more significant role for the younger cohort than the older cohort, whereas being a Mainlander and occupational sector were no longer predictors of retirement for the younger cohort.

As shown in Table 5, the results were also dissimilar for the 1993 and 1996 waves among the older Panel A cohort. In Models 1 and 2 of the 1993 wave, Mainlanders were $35.7 \%$ and $30.9 \%$, respectively, less likely than non-Mainlanders to be still working at age 64 and above. The likelihood of still working increased for Mainlanders after controlling for age and marital status in Model 2, but ethnicity was still a significant predictor of retirement for the older cohort as stated in Hypothesis 1. After including working in the public sector in Model 3, Mainlanders did not have a higher likelihood of retirement than non-Mainlanders. This confirms Hypothesis 2 that working in the public sector mediates the effect of ethnicity on the likelihood of retirement in the older cohort but not in the younger cohort. In 1996, however, when the men were at least 67 years old, ethnicity was no longer associated with the probability of retirement.

The interaction between working in the public sector and being a Mainlander on the odds of still working was not significant in Model 4 for both the 1993 and 1996 waves. In Model 3, a 1-year increase in age was related to a $9.8 \%$ and $9.7 \%$ decrease in the probability of still working in 1993 at age 64 and above and 1996 at age 67 and above, respectively, controlling for all the other variables in the model. Married men had a 1.416 and 1.627 times higher chance of still working than non-married men in 1993 and 1996, respectively. Education and occupational category were unrelated to the probability of still working. A one-unit increase in self-reported poor health decreased the likelihood of still working by $27.9 \%$ in 1996 . Men with a functional limitation were $67.5 \%$ and $58.4 \%$ less likely to be still working in 1993 and 1996, respectively, than those without a functional limitation. Finally, men who worked in the public sector had an $83.8 \%$ and $72.2 \%$ lower likelihood of still working than those who worked in the private sector in 1993 and 1996, respectively.

\section{Cumulative advantage or disadvantage}

Cumulative advantage or disadvantage (CAD) can be regarded as the systemic tendency for inter-individual divergence in a specific feature (e.g., money, health, or status) with the progress of time [43]. The inter-individual divergence derives from the interaction of social forces over time but not necessarily from individuals' positions at the point of origin [43]. CAD reverberates with old sayings, such as "success breeds success" and "the rich get richer; the poor get poorer" and helps to interpret economic inequality across the life course $[44,45]$. It describes processes by which the effects of early economic, educational, and other advantages can cumulate over the life course. It also emphasizes that these processes are moderated by changing societal institutions [48]. This assumption of CAD in the life course perspective has two implications $[14,46]$. One is that the power of systemic determinants of inequality from structural arrangements, such as the educational and occupational sectors, is interrelated with individual behaviors or efforts. The other is that the timing, duration, and temporal characteristics of life transitions tend to strengthen accumulation of inequality.

Take Mainlanders as an example of the CAD approach: Compared to native nonMainlanders, Mainlanders were more likely to be employed in stable public sector jobs for their whole working life, for example, as military personnel, public teachers, or civil servants [47]. Soldiers, public school teachers, and civil servants 
have tenure track positions in Taiwan, so they experience unemployment far less than non-Mainlanders. Consistent with the cumulative advantage approach, they can reach the eligible age of receiving public pensions sooner than native laborers

\begin{tabular}{|c|c|c|}
\hline Year & Support for the elderly/pension schemes & Groups of people who access the scheme \\
\hline 1950 & Labor Insurance promulgated & $\begin{array}{l}\text { Private employees, self-employed, working } \\
\text { employers, seafarers, aged } 15+\end{array}$ \\
\hline 1953 & Fisherman Insurance promulgated & $\begin{array}{l}\text { Fishermen or Fishermen's Association } \\
\text { members }\end{array}$ \\
\hline 1958 & Government Employee Insurance promulgated & $\begin{array}{l}\text { Government employees, public school } \\
\text { teachers, and school employees }\end{array}$ \\
\hline 1958 & $\begin{array}{l}\text { Civil Servant and Teacher Insurance Act and } \\
\text { Public Insurance of Retired Civil Servants } \\
\text { promulgated }\end{array}$ & $\begin{array}{l}\text { Civil servants, public sector workers, public } \\
\text { school teachers }\end{array}$ \\
\hline 1960 & $\begin{array}{l}\text { Regulations for Preferential Interest Rate for } \\
\text { Retirement Payment of Retired Civil Servants }\end{array}$ & $\begin{array}{l}\text { Political appointees, civil servants, public } \\
\text { school teachers, and military personnel }\end{array}$ \\
\hline 1980 & $\begin{array}{l}\text { Insurance of Private School Teachers } \\
\text { promulgated }\end{array}$ & Private school teachers \\
\hline 1983 & $\begin{array}{l}\text { Implementation of the } 18 \% \text { Preferential Savings } \\
\text { Rate to Regulations for Preferential Interest Rate } \\
\text { for Retirement Payment of Retired Civil } \\
\text { Servants }\end{array}$ & $\begin{array}{l}\text { Political appointees, civil servants, public } \\
\text { school teachers, and military personnel }\end{array}$ \\
\hline 1984 & $\begin{array}{l}\text { Insurance of Retired Private School Teachers } \\
\text { promulgated }\end{array}$ & Retired private school teachers \\
\hline 1985 & $\begin{array}{l}\text { Old-age Farmer Welfare Allowance } \\
\text { promulgated }\end{array}$ & Farmers or Farmers' Association members \\
\hline 1993 & Civil Service Retirement Act promulgated & $\begin{array}{l}\text { Government employees, public school } \\
\text { teachers, and school employees }\end{array}$ \\
\hline 1995 & $\begin{array}{l}\text { Sunset Clause of the } 18 \% \text { Preferential Savings } \\
\text { Rate to Regulations for Preferential Interest Rate } \\
\text { for Retirement Payment of Retired Civil } \\
\text { Servants }\end{array}$ & $\begin{array}{l}\text { Political appointees, civil servants, public } \\
\text { school teachers, and military personnel }\end{array}$ \\
\hline 1995 & Public Service Pension Fund promulgated & $\begin{array}{l}\text { Political appointees, civil servants, public } \\
\text { school teachers, and military personnel }\end{array}$ \\
\hline 2008 & National Pension Program promulgated & All Taiwanese \\
\hline 2009 & Labor Insurance Act amended & $\begin{array}{l}\text { Change the eligibility age for private } \\
\text { employees, self-employed, working } \\
\text { employers, seafarers, aged } 15+\end{array}$ \\
\hline 2009 & $\begin{array}{l}\text { The Amendment Draft of the 85-plan in Civil } \\
\text { Service Retirement Act formulated and } \\
\text { announced }\end{array}$ & $\begin{array}{l}\text { Retired civil servants and public school } \\
\text { teachers }\end{array}$ \\
\hline 2017 & $\begin{array}{l}\text { Act Governing Civil Servants' Retirement, } \\
\text { Discharge and Pensions (including } \\
\text { implementation of the 85-plan) promulgated } \\
\text { Act Governing the Retirement and Pensions of } \\
\text { Public School Teachers and Employees } \\
\text { promulgated }\end{array}$ & $\begin{array}{l}\text { Retired civil servants and public school } \\
\text { teachers }\end{array}$ \\
\hline 2018 & $\begin{array}{l}\text { Act of Military Service for Officers and } \\
\text { Noncommissioned Officers of the Armed Forces } \\
\text { promulgated }\end{array}$ & Retired military personnel \\
\hline
\end{tabular}

Table 6.

Pension scheme enactment and reform in Taiwan. 
who often have low-wage jobs without health insurance coverage and are more likely to be laid off. As Radl pointed out in relation to social stratification in Western Europe, people with accumulated pension rights or significant wealth assets can afford to retire earlier than those without those privileges [48]. Thus, Mainlanders were more likely than non-Mainlanders to leave the labor force earlier and receive a pension income.

Moreover, public pension programs benefited Mainlanders more than nonMainlanders. Government Employee Insurance (GEI) and Veteran Insurance (VI) are the public pension programs for military personnel, public teachers, and civil servants, who are white-collar, middle-class workers. GEI and VI have much higher income replacement ratios (over 90\%) in retirement income than Labor Insurance (LI) with its less than 50\% replacement ratio [47]. When the interest rate of special savings is added to GEI and VI, the replacement rate exceeds $100 \%$ [49]. Since pension satisfaction generates higher retirement incentives, GEI and VI, regarded as institutional constraints, can become the "push factors" that caused Mainlanders to retire earlier. These pension schemes are summarized in Table 6 [37, 38].

Overall the cumulative advantage for Mainlanders was reduced by democratization and modernization in the 1980s with increasing labor force participation among minorities, including women and non-Mainlanders. The Ten Construction Projects were held in the 1970 s by the Taiwan government, martial law was abolished in 1989, a National Health Insurance was implemented in March 1995, and the first president, Lee Teng-hui, was elected by Taiwan citizens in 1996. Between 1970 and 1990, Taiwan became one of the "Four Asian Tigers" and rapidly expanded economic development. During this period, ethnic equality improved under the context of greater economic development, a higher degree of democratization and modernization, better employment opportunities, and stronger commitments to sociopolitical causes, such as the social movement for employment opportunity equality [3]. Unlike the older cohort who tended to be GEI and VI receivers, the younger Mainlander cohort was less likely to work in the public sector and tended to have less power compared to older Mainlanders. Hence, "working in the public sector" partially mediated the effect of ethnicity on retirement for the older cohort but not for the younger cohort.

\section{Discussion}

As predicted in Hypothesis 1, we found significant ethnic inequality in retirement, which was mediated by age, marital status, socioeconomic status, and health conditions. Moreover, the effect of ethnicity on the likelihood of retirement was significantly reduced in the older cohort but not in the younger cohort after controlling for working in the public sector, corroborating Hypothesis 2. Mainlanders who worked in public sectors were more likely to retire than others, which supports Hypothesis 3. In addition, men who were Mainlanders, older, non-married, and in poor health were more likely to be retired than those who were non-Mainlanders, younger, married, and in good health.

\subsection{The effects of marital status, social class, and ill health on retirement}

In a patriarchic society, such as Taiwan, the man is always supposed to be the breadwinner [42]. Married men are expected to take responsibility for the family's economic security and become financial contributors to their adult children's economic well-being, which explains the higher likelihood of extending their work life and delaying the onset of retirement compared to non-married men [36, 50,51]. 
However, education and occupational category, regarded as indicators of social class, were not significantly related to the likelihood of retirement. By contrast, health was a robust predictor of retirement. Similar to prior research, self-reported poor health [11, 52-55] and physical disability [18-21] largely explained why men retired earlier. Physical impairments, such as mobility limitations, could be one of the most salient reasons for leaving the labor force. Congruent with a particular pension policy $[20,48,55]$, public sector workers had a higher likelihood of earlier retirement than private sector workers but only in the older cohort.

\subsection{The effect of ethnicity on retirement differs by cohort}

As expected, the effect of ethnicity on the likelihood of earlier retirement was fully explained by occupational sector. Working in the public sector mediated and moderated the effect of ethnicity on the likelihood of still working in the older cohort. After adding public sector worker to the model, ethnicity was no longer significantly related to the probability of still working, and Mainlanders who worked in the public sector were least likely to be still in the labor force in 1989 at age 60 and above. This is consistent with current studies [24, 35, 48], suggesting that exposure to favorable employment circumstances across the life course, such as pension eligibility and the incentive structure of public pensions for public sector workers, can contribute to the higher likelihood of earlier retirement and pension receipt in later life.

Yet, the younger cohort in 1996, Panel B, faced a different situation. In bivariate associations, Mainlanders were also significantly more likely to retire earlier than non-Mainlanders. However, after controlling for age and marital status, being a Mainlander was no longer associated with earlier retirement. Age and marital status, rather than working in the public sector, explain why Mainlanders tended to retire earlier than non-Mainlanders in the younger cohort. Yet, working in the public sector was the strongest predictor of earlier retirement among Mainlanders in the older cohort of Panel A. This suggests that the pension reform in the 1980s improved the retirement situation for private sector workers [56-58] as shown in Table 6. Labor Insurance expanded its entitlement coverage of the Taiwanese population dramatically from $4.4 \%$ in 1961 to $40.1 \%$ in 1994 compared to civil servant-related insurances whose coverage of the population only increased from $1.9 \%$ in 1961 to $8.5 \%$ in 1994 [56]. This means that compared to civil servant-related insurances, Labor Insurance covered an increasing percentage of the Taiwanese population from 1961 to 1994 . The new pension eligibility and coverage after the implementation of the pension reform appeared to have resulted in distinct retirement trajectories of the two cohorts.

Our results are consistent with past studies $[59,60]$, which found that retirement trajectories differ by cohorts. For example, Carlson [60] showed that the Lucky Few cohort, born between 1929 and 1945, had a lower unemployment rate and a more stable employment history and retired earlier than other cohorts. By contrast, members of the baby boom cohort were laid off more frequently, tended to have a lower salary, and could not afford to retire early due to the economic crisis of 2008 [60]. In short, every cohort forms a distinct retirement pattern based on its particular employment pattern and the operation of social processes through cumulative advantage or disadvantage.

The pension system in Taiwan is based on occupational pensions [61]. Whether men, as breadwinners, can afford to retire is largely driven by the incentive structure of public pensions [12, 48, 62]. Those who work in the public sector tend to reach the eligibility of full retirement benefits earlier and with a larger income 
replacement ratio, which allows them to leave the labor force earlier than those who work in lower social class private sector jobs [47, 49].

Despite the well-documented impact of the employment history in cumulative advantage, research on the linkage between the occupational sector and earlier retirement remains limited. Also, the first publications that linked CAD with age $[63,64]$ neglected aspects of cohort; we enrich the CAD theory and underline CAD is a not a property of individuals but of cohort collectivities. In this study, we used unique data collected across two different cohorts of ethnic groups, Mainlanders and the native group of non-Mainlanders, i.e., Southern Min, Hakka, and indigenous people, to evaluate pathways to earlier retirement. We found that Mainlander status, working in the public sector, older age, nonmarital status, poor health, and functional limitation were associated with a higher likelihood of earlier retirement. Consistent with our hypotheses based on the theory of cumulative advantage/disadvantage, the occupational sector was an important mediator and moderator in explaining the link between ethnicity and the odds of earlier retirement in the older cohort. The results suggest that employment experiences in middle age shape retirement trajectories and result in socioeconomic inequality in old age, as demonstrated by Mainlanders' higher probability of retirement under the age of 60 .

In sum, this study showed that working in the public sector decreased Mainlanders' likelihood of staying in the labor force longer, but only among the older cohort. This means that structural factors can fully explain the effect of ethnicity on retirement, suggesting a cumulative advantage of earlier retirement for Mainlanders compared to Southern Min, Hakka, and indigenous people, formed by the structural factor of "pension policy," which favors the public sector.

Our nationwide, population-based study found that Mainlanders were more likely to retire earlier than non-Mainlanders. After controlling for working in the public sector, the effect of being a Mainlander on the likelihood of earlier retirement decreased significantly. Besides working in the public sector, older age, selfreported poor health, and functional limitation were also significantly related to earlier retirement.

Our study has two important limitations. First, the sample size was small for those who faced the risk of retirement between the age of 60 and 70 in Panel B. In particular, the subsample of Mainlanders in Panel B is much smaller than in Panel A, which might increase heterogeneity in the timing of retirement. Second, we were unable to trace health conditions at earlier older ages since we only consider health conditions at age 60 and above within the study period of both panels. This might suppress the effect of earlier ill health on retirement decisions.

In 2009, two new pension policies were introduced in Taiwan as Table 6 shows, but they still favor public sector workers. For blue-collar workers, the government enacted a new public pension policy to solve the problem of population aging and the deficit in the retirement benefit fund. Laborers who have accumulated more than 25 working years or those who have worked for more than 15 years by age 60 and above are eligible to enroll in Labor Insurance since 2017 but are required to postpone normal retirement age until age 61 in 2019, age 62 in 2020, age 63 in 2022, age 64 in 2024, and age 65 in 2026 [65]. If they have worked for 15 years or more, they are eligible to get reduced retirement benefits up to 5 years earlier than the normal retirement age. They would receive $4 \%$ less than their full benefits for every year they claimed the retirement benefit earlier than the full retirement age. For example, a person who has worked for at least 15 years is eligible to claim retirement benefits at age 60 in 2026, but doing so will result in a reduction of benefits by 20 percent. Reduced benefits are likely to be insufficient to cover the cost of living. 
A new pension policy was also was formulated for public sector workers. Before 2009, people who worked in the public sector for at least 25 years were eligible to retire and receive a pension. In 2009, the new pension policy was announced, which requires that the sum of workers' current age and their working years (at least 25 years) is 85 or larger to be eligible to retire at full benefits (the 85-plan in Table 6). For example, an individual who started work at age 30 would be eligible to retire at age 55 but only get $80 \%$ of full retirement benefits [66]. Individuals who retired at $56,57,58$, or 59 years of age would get $84 \%, 88 \%, 92 \%$, or $96 \%$ of full benefits, respectively [66], before 2025 [67]. The eligible age will change into 60 years old during 2026-2030 and 65 years old after 2031 according to the government pension reform [67].

Based on the new polices, the eligible age for receiving retirement benefits is higher for blue-collar workers than public sector workers, while pensions and income replacement ratios are much higher for public sector workers than bluecollar workers, which creates inequality in retirement in Taiwan. Due to an ethnic inequality in workplace retirement plan coverage, raising the retirement age is likely to reduce the minority group's lifetime-expected benefits by a larger percentage than that of the majority group, especially for blue-collar workers.

\section{Conclusion}

The study offers several policy implications. First, policymakers should take occupational categories, occupational sectors, and income replacement ratios into consideration to build a new and more equitable pension scheme. Admittedly, Chen [37] argued that the new pension reform in 2017 may not attract younger generations to work in the public sector since the income replacement ratio for retired civil servants and public school teachers will gradually be reduced from $75 \%$ to $60 \%$ over a period of 10 years and the $18 \%$ preferential savings rate ${ }^{2}$ of retirement income for 450,000 retired teachers, soldiers, and bureaucrats [34] will be reduced to $0 \%$ on 1 January 2021 according to the Act Governing Civil Servants' Retirement, Discharge and Pensions and the Act Governing the Retirement and Pensions of Public School Teachers and Employees, passed in June 2017 by Taiwan's Legislative Yuan [37] as shown in Table 6 . Yet, the $18 \%$ preferential rate will still be in place for retired civil servants and public school teachers whose monthly pension is below the threshold of either $\$ 833$ USD or $\$ 1067$ USD, respectively. The 18\% preferential savings rate for retired military personnel will be gradually phased out over 10 years based on the Act of Military Service for Officers and Noncommissioned Officers of the Armed Forces, enacted in 2018 [37]. However, civil servants' salaries tend to be higher than private workers' salaries. Even though the retirement income replacement ratio has become equivalent, private sector workers' retirement income is still

\footnotetext{
${ }^{2}$ People who worked in the public sector with an employment history before 1995 have an over 100\% retirement income replacement ratio. Retired military personnel, civil servants, public school teachers, and public sector laborers used to have an $18 \%$ preferential savings rate for their pension. On average, retired public sector workers received \$2278 USD per month, compared to the \$1317 USD monthly earnings of average Taiwanese workers or the $\$ 733$ USD monthly earnings of a fresh university graduate. Since Mainlanders are more likely to be retired military personnel, retired civil servants, public school teachers, and public sector workers, this advantage still currently exists. However, this advantage may be reduced in the near future due to the new pension reform.
} 
likely to be lower than that of public sector workers. More importantly, civil service welfare, based on the Civil Servant and Teacher Insurance Act and Public Insurance of Retired Civil Servants, provides many more benefits than the private sector welfare from Labor Insurance and other insurance for private sectors, such as the children education subsidy, the allowance for dependents' funerals, the allowance for marriage and birth, Funeral Leave, and so on. These could contribute to the pension inequality of occupational sectors.

Second, our results show that self-reported poor health and functional limitation was related to a higher likelihood of earlier retirement. Since blue-collar workers work in physically demanding jobs and are, therefore, more likely to have poor health and functional limitations, the government should implement the same retirement eligibility age for blue-collar workers and public sector workers and provide supplemental financial assistance to specific disadvantaged groups of older workers, especially blue-collar workers in poor health.

Third, the findings supported our hypotheses that the reason why Mainlanders were more likely to retire earlier than non-Mainlanders was due to their overrepresentation as public sector workers. Private sector workers are more likely to have a more interrupted employment history than public sector workers with tenure track jobs. By contrast, public sector workers are more likely to be eligible for full pension benefits earlier than those in the private sector, which becomes a strong incentive to leave the labor force. Policymakers could change these benefit incentives if they wanted to raise the labor force participation rates of Mainlanders and middle-aged and young old public sector workers. Future studies should consider more recent data, include women in the overall assessment, and look at health in late middle age to understand its impact on retirement.

\section{Abbreviations}

$\begin{array}{ll}\text { KMT } & \text { Kuomintang } \\ \text { PRC } & \text { People's Republic of China } \\ \text { CAD } & \text { cumulative advantage or disadvantage } \\ \text { DB } & \text { defined benefit plans } \\ \text { DC } & \text { defined contribution plans } \\ \text { USD } & \text { US dollar } \\ \text { TLSA } & \text { Taiwan Longitudinal Study in Aging } \\ \text { LI } & \text { Labor Insurance } \\ \text { OAF } & \text { Old-age Farmer Welfare Allowance } \\ \text { GEI } & \text { Government Employee Insurance } \\ \text { VHA } & \text { Veteran Homecare Allowance } \\ \text { PSPF } & \text { Public Service Pension Fund }\end{array}$




\section{Author details}

Fang-Yi Huang ${ }^{1 *}$ and Monika Ardelt ${ }^{2}$

1 Institute of European and American Studies, Academia Sinica, Taipei City, Taiwan

2 Sociology and Criminology and Law, University of Florida, Gainesvill, United States

*Address all correspondence to: voyage213@ufl.edu

\section{IntechOpen}

(C) 2020 The Author(s). Licensee IntechOpen. This chapter is distributed under the terms of the Creative Commons Attribution License (http://creativecommons.org/licenses/ by/3.0), which permits unrestricted use, distribution, and reproduction in any medium, provided the original work is properly cited. (c) BY 


\section{References}

[1] Honig M. Retirement expectations: Differences by race, ethnicity, and gender. The Gerontologist. 1996;36(3): 373-382

[2] Kubler CC. The influence of southern min on the mandarin of Taiwan. Anthropological Linguistics. 1985;27(2): 156-176

[3] Lu M-L. The Changing Status of Women in Taiwan: 1945-2010. 2012. Available from: https://etd.auburn.edu/ handle/10415/3100

[4] Kav MY-M, Simon DF. Taiwan: Beyond the Economic Miracle: Beyond the Economic Miracle. New York, United States: Routledge; 2016. p. 581

[5] Wedeman AH. Double Paradox: Rapid Growth and Rising Corruption in China. Ithaca, NY: Cornell University Press; 2012. p. 272

[6] Martin LG, Zimmer Z, Hurng B-S. Trends in late-life disability in Taiwan: The roles of education, environment, and technology. Population Studies. 2011;65(3):289-304

[7] Hung W-S. An economic analysis of retirement decisions in Taiwan [Internet] [Doctoral]. Durham University; 2009. Available from: http:// etheses.dur.ac.uk/2114/

[8] Angel JL, Mudrazija S. Raising the retirement age: Is it fair for low-income workers and minorities? Public Policy Aging Report. 2011;21(2):14-21

[9] Zajacova A, Montez JK, Herd P. Socioeconomic disparities in health among older adults and the implications for the retirement age debate: A brief report. Journals of Gerontology Series B Psychological Sciences and Social Sciences. 2014;69(6):973-978

[10] Ghilarducci T, Moore K. Racially Disparate Effects of Raising the
Retirement Age. Schwartz Cent Econ Policy Anal Dep Econ. New York, NY: The New School for Social Research; 2015

[11] Pienta AM, Hayward MD. Who expects to continue working after age 62 ? The retirement plans of couples. Journals of Gerontology Series B Psychological Sciences and Social Sciences. 2002;57(4): S199-S208

[12] Radl J. Retirement Timing and Social Stratification, A Comparative Study of Labor Market Exit and Age Norms in Western Europe [Internet]. Berlin: De Gruyter Open; 2014. Available from: https://www.degruyter. com/view/product/209757

[13] Estes CL, DiCarlo NB. The Right to Work and the Right to Retire: A Political Economy Perspective on Precarity [Internet]. 2019. Available from: https:// chinesesites.library.ingentaconnect. com/content/asag/gen/2019/00000043/ 00000003/art00006

[14] Elder GH, Johnson MK, Crosnoe R. The emergence and development of life course theory. In: Mortimer JT, Shanahan MJ, editors. Handbook of the Life Course [Internet], Handbooks of Sociology and Social Research. Boston, MA: Springer; 2003

[15] Shuey KM, Willson AE. Trajectories of work disability and economic insecurity approaching retirement. Journals of Gerontology, Series B. 2019; 74(7):1200-1210

[16] Lahelma E, Pietiläinen O, Chandola T, Hyde M, Rahkonen O, Lallukka T. Occupational social class trajectories in physical functioning among employed women from midlife to retirement. BMC Public Health. 2019;19(1):1525

[17] Choi E, Tang F, Copeland VC. Racial/ethnic inequality among older 
workers: Focusing on whites, blacks, and latinos within the cumulative advantage/disadvantage framework. Journal of Social Service Research. 2017; 43(1):18-36

[18] Ghilarducci T, Moore K. Racially Disparate Effects of Raising the Retirement Age [Internet]. Schwartz Center for Economic Policy Analysis (SCEPA), The New School. (SCEPA Working Paper Series. SCEPA's Main Areas of Research are Macroeconomic Policy, Inequality and Poverty, and Globalization.). Report No.: 2015-03. 2015. Available from: https://ideas.repec .org/p/epa/cepawp/2015-03.html

[19] Green CA. Race, ethnicity, and social security retirement age in the us. Feminist Economics. 2005;11(2):117-143

[20] Hayward MD, Grady WR, Hardy MA, Sommers D. Occupational influences on retirement, disability, and death. Demography. 1989;26(3): 393-409

[21] Mudrazija S. Gender, Race and the Transition to Retirement among the Baby Boomers. Texas: University of Texas at Austin; 2010

[22] Solem PE, Syse A, Furunes T, Mykletun RJ, Lange AD, Schaufeli W, et al. To leave or not to leave:

Retirement intentions and retirement behaviour. Ageing \& Society. 2016; 36(2):259-281

[23] Farnham M, Sevak P. Housing wealth and retirement timing. CESifo Economic Studies. 2016;62(1):26-46

[24] Raymo JM, Warren JR, Sweeney MM, Hauser RM, Ho JH. Precarious employment, bad jobs, labor unions, and early retirement. Journals of Gerontology Series B: Psychological Sciences and Social Sciences. 2011;66B (2):249-259

[25] Duval R. The Retirement Effects of Old-Age Pension and Early Retirement
Schemes in OECD Countries. 2003. Available from: https://www.oecdilibrary.org/economics/the-retirementeffects-of-old-age-pension-and-earlyretirement-schemes-in-oecd-countries 308728704511

[26] Munnell AH, Sanzenbacher GT, Houand W. Trends in Retirement Security by Race/Ethnicity | Center for Retirement Research [Internet]. 2018. Available from: https://crr.bc.edu/brief s/trends-in-retirement-security-byraceethnicity/

[27] Coile C, Gruber J. Future social security entitlements and the retirement decision. Review of Economics and Statistics. 2007;89(2):234-246

[28] Chan S, Stevens AH. Do changes in pension incentives affect retirement? A longitudinal study of subjective retirement expectations. Journal of Public Economics. 2004;88(7): 1307-1333

[29] Butrica BA, Smith KE. Racial and ethnic differences in the retirement prospects of divorced women in the baby boom and generation X Cohorts. Social Security Bulletin. 2012;72(1). Available from: https://www.ssa.gov/ policy/docs/ssb/v72n1/v72n1p23.html

[30] Bloemen H, Hochguertel S, Zweerink J. The causal effect of retirement on mortality: Evidence from targeted incentives to retire early. Health Economics. 2017;26(12):e204e218

[31] Sanzenbacher GT, Ramos-Mercado JD. Calculating Expected Social Security Benefits by Race, Education, and Claiming Age. Chestnut Hill, MA: Center for Retirement Research at Boston College; 2016. Available from: http://socionet.ru/publication.xml?h= repec:crr:crrwps:wp2016-14

[32] Butrica BA, Iams HM, Smith KE, Toder EJ. The disappearing defined 
benefit pension and its potential impact on the retirement incomes of baby boomers. Social Security Bulletin. 2009; 69(3):1-27

[33] Helppie MFB. Crash and wait? The impact of the great recession on the retirement plans of older Americans. American Economic Review. 2011; 101(3):40-44

[34] The Economist. Taking on Taiwan's ruinous and partisan pension system. The Economist [Internet]. 2017. Available from: https://www.economist. com/asia/2017/05/18/taking-ontaiwans-ruinous-and-partisan-pensionsystem

[35] Rhee N. Race and Retirement Insecurity in the United States. Natl Inst Retire Secur [Internet]. 2013. Available from: https://www.nirsonline.org/ reports/race-and-retirement-insecurityin-the-united-states/

[36] Henretta JC, O’Rand AM. Age and Inequality: Diverse Pathways through Later Life [Internet]. Boulder, Colorado: Westview Press; 1999. Available from: http://trove.nla.gov.au/version/ 39607592

[37] Chen C-H. Taiwan's pension crisis. Economic and Political Weekly. 2018; 53(50):7-8

[38] Hsieh K, Sinica A, Tung A-C. Taiwan's National Pension Program: A Remedy for Rapid Population Aging? ResearchGate [Internet]. 2016. Available from: https://www. researchgate.net/publication/ 301851388_Taiwan's_National_ Pension_Program_A_Remedy_for_ Rapid_Population_Aging

[39] Hu T-L. Ethnic identity a social condition of veteran-mainlanders in Taiwan. Revue Européenne des Sciences Sociales. 1989;27(84):253-265

[40] Schubert G, Damm J. Taiwanese Identity in the 21st Century: Domestic,
Regional and Global Perspectives. New York, NY, United States: Routledge; 2012. p. 300

[41] Taipei Times. Gender Gap Narrowed in Last Year's Labor Force [Internet]. 2018. Available from: http:// www.taipeitimes.com/News/taiwan/ archives/2018/09/16/2003700538

[42] Lu M-L. The Changing Status of Women in Taiwan: 1945-2010. 2012

[43] Dannefer D. Cumulative advantage/ disadvantage and the life course: Crossfertilizing age and social science theory. Journals of Gerontology, Series B. 2003; 58(6):S327-S337

[44] Merton RK. The Matthew effect in science, II: Cumulative advantage and the symbolism of intellectual property. Isis. 1988;79(4):606-623

[45] Merton RK. The Matthew effect in science: The reward and communication systems of science are considered.

Science. 1968;159(3810):56-63

[46] Dannefer D. Age, the Life Course, and the Sociological Imagination: Prospects for Theory. In: George L, editor. Handbook of Aging and the Social Sciences. Cambridge, Massachusetts, United States: Imprint of Elsevier, Acad Press [Internet]; 2011. Available from: https://www. mysciencework.com/publication/show/ fe6ce37981de13b930e3a0bd81482b94

[47] Bonoli G, Shinkawa T. Ageing and Pension Reform Around the World: Evidence from Eleven Countries. Cheltenham Glos, UK: Edward Elgar Publishing Ltd; 2006. p. 292

[48] Radl J. Labour market exit and social stratification in Western Europe: The effects of social class and gender on the timing of retirement. European Sociological Review. 2013;29(3): 654-668 
[49] Lin C-W. Pension Reform in

Taiwan: The Old and the New Politics of Welfare [Internet]. Cheltenham Glos, UK: Edward Elgar Publishing Ltd; 2005. Available from: http://econpapers.repec. org/bookchap/elgeechap/3368_5f9.htm

[50] Schwartz CR. Earnings inequality and the changing association between spouses' earnings. AJS. 2010;115(5): 1524-1557

[51] Whitaker EA, Bokemeier JL. Spousal, family and gender effects on expected retirement age for married pre-retirees. Journal of Family and Economic Issues. 2018;39(3): 371-385

[52] Dwyer DS, Mitchell OS. Health Problems as Determinants of Retirement: Are Self-Rated Measures Endogenous? [Internet]. National Bureau of Economic Research; 1998. Report No.: 6503. Available from: http:// www.nber.org/papers/w6503

[53] Pit SW, Shrestha R, Schofield D, Passey M. Health problems and retirement due to ill-health among Australian retirees aged 45-64 years. Health Policy. 2010;94(2):175-181

[54] Radl J. Retirement Timing and Social Stratification: A Comparative Study of Labor Market Exit and Age Norms in Western Europe. Berlin, Germany: Walter de Gruyter; 2014. p. 329

[55] Leinonen T, Laaksonen M, Chandola T, Martikainen P. Health as a predictor of early retirement before and after introduction of a flexible statutory pension age in Finland. Social Science \& Medicine. 2016;158:149-157

[56] Wang HS. Historical development of NHI in Taiwan: De-familialization path of welfare politics. In: Wang HS, editor. Familial Foundations of the Welfare State: Building the National Health Insurance Systems in South
Korea and Taiwan [Internet]. Cham:

Springer International Publishing; 2017.

pp. 107-137. DOI: 10.1007/978-3-

319-58712-7_5

[57] Aspalter C. Discovering the Welfare State in East Asia. Westport, CT, United States: Greenwood Publishing Group; 2002. p. 216

[58] Kuo M-C. Privatization Versus the Right to Social Security: The Taiwan Case. 2007

[59] Betti G, Bettio F, Georgiadis T, Tinios P. Unequal Ageing in Europe: Women's Independence and Pensions. New York: Palgrave Macmillan US; 2015

[60] Carlson E. The Lucky Few: Between the Greatest Generation and the Baby Boom. 2008

[61] Hsieh KY-C, Tung A-C. Taiwan's national pension program: A remedy for rapid population aging? Journal of the Economics of Ageing. 2016;8:52-66

[62] Gruber J, Wise DA. Social Security Programs and Retirement around the World: The Relationship to Youth Employment. United States: University of Chicago Press; 2010. p. 380

[63] Dannefer D. Differential gerontology and the stratified life course: Conceptual and methodological issues. Annual Review of Gerontology and Geriatrics. 1988;8:3-36

[64] Dannefer D. Aging as intracohort differentiation: Accentuation, the Matthew effect, and the life course. Sociological Forum. 1987;2(2):211-236

[65] Bureau of Labor Insurance M of L. The Entilte Age of Labor Insurance (2018) [Internet]. 2018. Available from: https://www.bli.gov.tw/0023192. html

[66] Taipei Veterans General Hospital TS of PSW. The Eligibility Requirement of Public Sector Workers' Retirement Age 
Pathways to Retirement in Taiwan: Do Ethnicity and Cohort Matter? DOI: http://dx.doi.org/10.5772/intechopen.92147

[Internet]. DC. Source. 2018. Available from: https://wd.vghtpe.gov.tw/tvgms/ Fpage.action?muid=2

[67] Ministry of Civil Service. Pension Reform for Civil servants, Public Sector Workers, Public School Teachers [Internet]. Ministry of Civil Service; 2017. Available from: http://bit.ly/ 2wopgdb 



\title{
Alternatives to Serve the Interests of Russian Pensioners
}

\author{
Elena Ivanovna Kulikova
}

\begin{abstract}
The results of the analysis of statistical data on the Russian labor market, employment and wages, as well as the specific features of the Russian pension system, provide the basis for several important conclusions. Firstly, the living standards of the majority of Russian pensioners do not meet their needs as the Russian pension system is focused on the achievement of minimum living standards. Secondly, the regulation on the functioning of the pension system established by Russian legislation is often violated by the regulators without coordination with economic entities and citizens, participants of the pension system, which prevents future pensioners from feeling protected upon retirement. For this reason, citizens of the retirement age do not seek to retire even when they reach the retirement age. The growth rate of working pensioners (who pay taxes, including insurance deductions to the Pension Fund of Russia and private pension funds) confirms this. Thirdly, there is a need to create a socially-comfortable environment for pensioners, to counteract the psychological problems of older people their sense of "uselessness" to society. The article proposes practical measures to mitigate the negative phenomena in the pension provision of Russian citizens.
\end{abstract}

Keywords: pensioner, living standard, retirement age, pension system, subsistence level of a pensioner, pension benefits, pensions

\section{Introduction}

The pension provision for citizens is the most important component of any state social policy, Russia being no exception, since the right to social security is enshrined in international laws, such as the Universal Declaration of Human Rights [1], the International Covenant on Economic, Social and Cultural Rights [2] and other.

The reformation of the Russian pension system, which had been based on the "solidarity of generations" principle (pensions are paid from the pension contributions of working citizens), was launched in 2002. The funded component of the labor pension was introduced for a certain age group of Russian citizens (women and men born in 1967 and younger take part in it) and was introduced on a mandatory basis. The concept of the pension system featured a number of innovations for the Russian economy:

1. The creation of pension institutions in the form of legislative and regulatory acts; pension system management bodies - the Federal Service for Financial Markets (FSFM), the Ministry of Finance and the Ministry of Labor and Social 
Protection; as well as pension financial institutions - the Pension Fund of Russia (PFR) and non-state pension funds (NPF);

2. The creation of a system for investing pension funds in the financial market through non-state pension funds;

3. The creation of a non-state pension system for the formation of corporate (voluntary) pensions.

The reform had the following prerequisites: the demographic factor (increased life expectancy and falling birth rate); the need to establish the dependence of the pension level on income, which requires the use of unique knowledge and skills by a citizen, i.e. elimination of the egalitarian nature of the state pension system; the need to reduce the dependence of state obligations in terms of social security on social payments [3].

The objective of the Russian pension system reformation was to increase the economic opportunities of citizens upon retirement thanks to savings made during an active working age, and to reduce the amount of state obligations towards senior citizens.

\section{Methodology}

The research methodology includes:

- analysis of scientific works on pension issues of famous economists Abramov A.E., Danilov Y.A., Disney R., Guseva I.A., Schulz H.J.;

- analysis of normative Russian and international regulatory documents and guidance on pension issues;

- analysis of statistical data on the Russian labor market, employment and wages, as well as features of the Russian pension system.

This led to the conclusion that the following factors should be taken into account when studying the income level of pensioners:

1. The sufficient size of the pension;

2. The availability of savings;

3. The availability of additional cash sources;

4. The availability of benefits and social assistance.

\section{Analysis/discussion}

The guaranteed level of a pensioner's financial support in Russia is legislatively oriented to the minimum wage [4], which determines the creation of an additional social protection system.

When analyzing statistics on labor relations, it becomes obvious that the pension size is not sufficient to ensure a dignified life for a pensioner (definition of a 
"Dignified life" term is not fixed in the Russian law). Pensioner's dignified life means for us the ability to not only eat normally and pay utility bills (in Russia pensioners have the privilege for reduced bill payment) but also the opportunity to enjoy leisure and go on vacation, buy gifts to grandchildren or spend time with them in the Disneyland (in Moscow they call it Dream Island). Table 1 shows minimal prices for services and tickets as well as the ratio of these prices to pension rates in Moscow as of 2018.

It is important to note that this data is true for the city of Moscow, pensioners in small towns and villages have limited opportunities.

This conclusion is confirmed by the results of the statistical data analysis on the Russian labor market, employment and salaries (Table 2).

Table 2 shows that the ratio of accrued pensions to employee salary (replacement rate) slightly exceeds $30 \%$ and demonstrates a downward trend. It should be noted that according to Convention No. 102: Social Security (Minimum Standards) (Geneva, June 20, 1952) of the International Labor Organization (ILO), the replacement rate for pensioners should not be less than $40 \%$ of the salary a citizen had prior to retirement. In Russia, this standard is not met.

Thus, we can conclude that pensioners' economic opportunities do not allow them to maintain an acceptable standard of living if pension is their only source of income.

Table 2 shows the average data for the country, therefore, we believe that when conducting more detailed studies in this area, it is necessary to take into account the regional characteristics of the Russian Federation, namely the vast extent of the territory with various climatic zones and significant differences in the economic development of 85 Russian regions. The size of pensions and the minimum wage in

\begin{tabular}{|c|c|c|c|}
\hline No & Aspect & Price, rubles & $\begin{array}{l}\text { The ratio of the price to } \\
\text { the average pension rate }\end{array}$ \\
\hline 1 & $\begin{array}{l}\text { Minimum subsistence level (a commodity } \\
\text { basket + utility bill costs) }\end{array}$ & 10,287 & $77 \%$ \\
\hline 2 & Visit to a cinema show & 400 & $3 \%$ \\
\hline 3 & Visit to a theatre & 500 & $4 \%$ \\
\hline 4 & Average restaurant lunch bill & 1000 & $7.5 \%$ \\
\hline 5 & Hair cut at an economy-class hairdresser & 300 & $2 \%$ \\
\hline 6 & Manicure & 500 & $4 \%$ \\
\hline 7 & Pedicure & 1600 & $12 \%$ \\
\hline 8 & $\begin{array}{l}\text { A visit to Disneyland with a grandchild: } \\
\text { - a pensioner discount ticket (on a weekday) } \\
\text { - a child's ticket (on a weekday) }\end{array}$ & $\begin{array}{l}1650 \\
1900\end{array}$ & $\begin{array}{c}12.4 \% \\
14 \%\end{array}$ \\
\hline 9 & $\begin{array}{l}\text { Rest in a sanatorium (recreational/medical } \\
\text { facility) (in Russia) }\end{array}$ & $\begin{array}{l}\text { For free, once } \\
\text { every two years }\end{array}$ & - \\
\hline 10 & Holidays abroad & $\begin{array}{l}\text { Paid from own } \\
\text { funds }\end{array}$ & - \\
\hline 11 & $\begin{array}{l}\text { Leisure-time activities - sporting activities, } \\
\text { language learning, mastering computer user } \\
\text { skills, etc. }\end{array}$ & $\begin{array}{l}\text { For free, Moscow } \\
\text { Longevity } \\
\text { program }\end{array}$ & - \\
\hline
\end{tabular}

Source: data from the Federal State Statistics Service (Analytical portal) [5].

Table 1.

The ratio of minimal prices for services to pension rates in Moscow at 2018. 


\begin{tabular}{|c|c|c|c|c|c|c|c|c|c|}
\hline Indictors, rubles & 2010 & 2011 & 2012 & 2013 & 2014 & 2015 & 2016 & 2017 & 2018 \\
\hline $\begin{array}{l}\text { Average pensions } \\
\text { awarded }\end{array}$ & 7476 & 8203 & 9041 & 9918 & 10786 & 11,986 & 12,391 & 12,887 & 13,360 \\
\hline $\begin{array}{l}\text { Minimum wage on } \\
\text { average per capita }\end{array}$ & 5688 & 6369 & 6510 & 7306 & 8050 & 9701 & 9828 & 10,088 & 10,287 \\
\hline $\begin{array}{l}\text { Average monthly } \\
\text { accrued salary of } \\
\text { employees }\end{array}$ & 20,952 & 23,369 & 26,629 & 29,792 & 32,495 & 34,4030 & 36,709 & 39,167 & 43,445 \\
\hline $\begin{array}{l}\text { Pensions/average } \\
\text { monthly salary size }\end{array}$ & 0.36 & 0.35 & 0.34 & 0.33 & 0.33 & 0.35 & 0.34 & 0.33 & 0.31 \\
\hline $\begin{array}{l}\text { Pensions/minimum } \\
\text { wage size }\end{array}$ & 1.31 & 1.29 & 1.39 & 1.36 & 1.34 & 1.24 & 1.26 & 1.28 & 1.3 \\
\hline
\end{tabular}

Table 2.

Some indicators of the Russian labor market and salaries and their correlation.

each region are different; moreover, pension provision also depends on the level of additional payments and benefits provided by regional authorities.

Regions and municipalities provide additional benefits to pensioners residing in this area. Such benefits most often include:

- tax benefits;

- public transport benefits;

- benefits for purchase of medication;

- health resort treatment benefits;

- discounted payment of utilities.

Since 2018, the Unified State Information System for State Social Security (EGISSO) has been operating in Russia, providing information on social support from budgets of all levels across the country and regions (benefits and subsidies).

There are various categories of pensioners, depending on age, marital status, general status, that have additional social benefits compared to recipients of agerelated pension. These categories include:

- single pensioners;

- Heroes of the Soviet Union and Heroes of Socialist Labor as well as citizens awarded with other state orders;

- Veterans of the Great Patriotic War (1941-1945);

- labor veterans (have an officially confirmed rank);

- military pensioners (citizens who have served the required amount of time in the armed forces of the Russian Federation);

- pensioners over 80 years of age; 
- pensioners over 70 years of age;

- disabled people.

As stated above, benefits in various regions are different, since the capacities of regional budgets also differ. Thus, pensioners in Moscow and St. Petersburg have more benefits than others, since the amount of budget funds in these cities is significantly higher compared to other cities. For example, in Moscow, all pensioners have the right to unlimited free travel on public transport, including the suburbs which certainly increase the mobility of senior people. In St. Petersburg, free suburban train passes have time limits. There are benefits for free garbage removal, for a tax on movable and immovable property of a pensioner, for the return of tax paid in previous years. Each region selects the most significant grounds for pensioners' benefits and compensation, depending on the capacities of the regional budget. The article further analyzes the amount of funds allocated by the state for social benefits and compensation in relation to pension payments.

However, it should be borne in mind that in each region the main objective of social benefits is to increase pensions to the minimum wage level established in a certain region of the country. Therefore, in this case we cannot speak about a socially acceptable level of pension protection for Russian citizens.

It is worth noting that the article provides the analysis for one type pension only and that is the insurance pension (that exists as state and funded pensions, formed from one source - insurance premium made by various institutions: the Pension Fund of Russia is responsible for the insurance pension component and private pension funds - for the funded one), since the first pensioner to receive a mandatory funded pension will retire in 2027 according to Russian law (the retirement age in Russia is 65 years for men, 60 years for women [7]). It is obvious that the funded pension will allow citizens to receive additional income. Today, as of June 30, 2019, 4620.2 billion rubles are concentrated in the system of mandatory savings (pension savings), and 1363.4 billion rubles are in the system of voluntary (corporate) pensions (pension reserves), which in total amounts to 5.5\% of the GDP of the Russian Federation. We also observe an increase in investment income, demonstrated by non-state pension funds for the indicated assets.

The Russian pension sector has long shown the best results among all segments of the non-banking financial market, also in case of international comparisons.

According to Russian economists, "thanks to the influx of new pension savings into private pension funds and management companies until 2014, as well as noticeable progress in the development of private pension funds after the adoption of legislation on the introduction of a system of guaranteeing pension contributions by the criterion of the pension savings size relative to GDP, Russia looked quite good against other BRIC countries, but significantly outrunning China and India, which still have underdeveloped pension savings systems" ([8], p. 27). Nevertheless, in 2014, the Government of the Russian Federation announced a moratorium on the transfer of insurance contributions to non-state pension funds for the mandatory funded pension until 2022, explaining it by the need to reduce the budget deficit of the Russian Pension Fund and, thus, increasing its obligations to citizens.

Unfortunately, from time to time the question of cancelling the existing system of funded pensions formation in its current form is brought up for discussion. The government is trying to prove that this system is ineffective; however, an analysis of private pension funds' activities shows that this is not true. Thus, according to the Central Bank of Russia (mega-regulator of the Russian financial market) [9], investments in the real sector of the economy, that make up $38 \%$ of the total assets of pension savings, dominate the portfolio of pension savings of non-state pension 


\begin{tabular}{lccccccccc}
\hline Indicator & $\mathbf{2 0 1 0}$ & $\mathbf{2 0 1 1}$ & $\mathbf{2 0 1 2}$ & $\mathbf{2 0 1 3}$ & $\mathbf{2 0 1 4}$ & $\mathbf{2 0 1 5}$ & $\mathbf{2 0 1 6}$ & $\mathbf{2 0 1 7}$ & $\mathbf{2 0 1 8}$ \\
\hline $\begin{array}{l}\text { Cash income of citizens, } \\
\text { billion rubles }\end{array}$ & 32,498 & 35,648 & 39,904 & 44,650 & 47,309 & 53,153 & 54,325 & 55,938 & 58,163 \\
\hline $\begin{array}{l}\text { Increase in financial assets } \\
\text { of citizens, billion rubles }\end{array}$ & 5614 & 4340 & 4161 & 4838 & 124 & 3803 & 3518 & 2566 & 826 \\
\hline $\begin{array}{l}\text { Share of savings in the } \\
\text { income of citizens, \% }\end{array}$ & 17.3 & 12.2 & 10.4 & 10.8 & 0.3 & 7.2 & 6.5 & 4.6 & 1.4 \\
\hline
\end{tabular}

Source: data from the Federal State Statistics Service (Analytical portal) [5].

Table 3.

The correlation of savings and income of Russian citizens.

funds. By the end of the year, the trend towards the redistribution of funds from the state and financial sectors to the real sector of the economy was observed in the portfolio of pension reserves. As a result, the amount of investments in the financial sector decreased to 689.3 billion rubles, while the amount of investments in the public sector decreased to 250.3 billion rubles. The share of pension reserves investments in the real sector in the portfolio amounted to $33.5 \%$.

These transformations of pension funds from one sector to another indicate the importance of pension money for the economy, while an increase in the return on these investments suggests an increase in investment efficiency, despite the unfavorable conditions created for the development of the funded pension on the Russian stock market. We believe that the funded pension that Russian citizens will start receiving in 2027 will significantly increase the pension coverage of Russian citizens. We would like to explain that the Russian pension system allows Russian citizens to choose whether they get a state pension only (in this instance, $22 \%$ of the payroll is paid to the Pension Fund of Russia) or a pension comprised of a state pension (16\% of the payroll is paid to the Pension Fund of Russia) and funded pension ( $6 \%$ of the payroll is paid to private pension funds). Currently 37 million Russian citizens generate pensions of both types, i.e. about $49 \%$ of 75 million economically active people (i.e. citizens capable of working). It suggests that the stratification of older people by income will not only continue, but also intensify.

Economic inequality exists both between senior people and the rest of the population, and among senior people themselves. Many lack income and opportunities to improve their financial situation (decent job) [10], they have no significant savings, nor additional sources of financing (funds invested in investment funds or in securities portfolios). The analysis of incomes and expenses of Russian citizens shows that the increase in their savings is insignificant (Table 3).

Based on the data in Table 3, we can conclude that the annual increase in savings of Russian citizens is less than $10 \%$ of their income, which will not allow them to accumulate a sufficient amount of savings and other assets to ensure their own economic security/independence in old age.

\section{What is being done and needs to be done to change the situation?}

Studies on pension provision [11-13] show that governments of different countries need to take serious measures to increase the sustainability of their pension systems when transferring responsibility for solving pension problems to the private sector. In accordance with the OECD [14] Core Principles of Private Pension Regulation, for their effective operation the following should be created: 
- effective legislation governing the pension sector;

- optimal infrastructure of financial markets;

- systems of optimization and risk control in managing pension funds;

- a reliable system of guarantees for the fulfillment of obligations, both for state and non-state pensions.

Regulatory principles proposed by the OECD have been developed and implemented in Russia. However, as a result of constant reformation of the pension system: changes in the age of citizens included in the pension system with a funded pension; moratorium on the transfer of a part of the insurance contribution to the funded pension (from 2014 to 2022); changes in the retirement age, etc., the level of citizens' confidence in the pension system decreases. Therefore, for Russian citizens, the availability of additional financial resources is very important.

Given the fact that the stock market began forming in Russia in the early 90s of the last century, Russian citizens have started developing skills in investing in the stock market recently. Until 2015, the number of private investors did not exceed 1 million people, however, in recent years, the main drivers of growth in the number of private investors were federal loan bonds "OFZ-n" called "popular" and individual investment accounts (IIAs) introduced on the Russian market, which were interesting for citizens as an investment mechanism and increased the number of private investors to 3.1 million people or $2 \%$ of the country's population (according to the Moscow Exchange). It should also be noted that in practice, these mechanisms are new for Russian investors and there is no statistics on the number of pensioners using the stock market as an additional source of income.

The Government of the Russian Federation is now proposing to transform the funded pension from mandatory to voluntary pension in order to encourage the activities of private investors in the financial market, as well as to solve the issue of pension capital formation. Under Russian law, pension funds of citizens are not their property. Despite the fact that the insurance premium for the insurance state pension is paid to the Pension Fund of Russia at the amount of $22 \%$ of a citizen's payroll (it is paid through an employer who acts as a withholding agent in this case), the state but not the citizen owns these funds. If a citizen builds up a funded pension as well ( $6 \%$ out of $22 \%$ of a payroll earned by this citizen), these funds belong to private pension funds and not to the citizen. This suggests unregulated property relations in Russia and does not allow Russian citizens to implement pension schemes of 401 (k) plan in the USA, which allows employees to manage pension savings themselves and to withdraw funds from an individual pension account for certain purposes and on certain conditions, as well as an IRA account on a tax-deferred basis [15].

We assume that the change in the conditions for the funded pension formation from a mandatory to a voluntary system is quite challenging today, as in Russia activation of citizens' choice of voluntary pension programs faces a number of restrictions that need to be taken into account when deciding on the priority development of this particular system:

1. low level of salaries of Russian citizens, which prevents them from investing in voluntary pension programs; 
2. insufficient development of the consulting and financial services system and high cost of such services, which prevents most citizens from understanding the features of the market mechanism and market products for investment;

3. the lack of developed mechanisms for the functioning of social partnership institutions, for example, trade unions, which in Western corporate pension systems establish, on the basis of collective agreements between employees and employers, different levels of pension contribution rates, different conditions for receiving pensions for different categories of workers;

4. poor information coverage of the activities of market financial institutions in the pension system.

Many older people in Russia rely on family support upon retirement. In Russia, a patriarchal family system still persists, when grandparents help in raising grandchildren. This is because of economic reasons (saving money on hiring a nanny, undeveloped habit of going out to eat, etc.), and the problem of spending leisure time with a child (long 3-month summer holidays at school require the organization of holidays for children and adolescents. It is the grandparents who look after their grandchildren since the parents are at work and the children do not go to school and are left on their own.). This allows many Russian pensioners to realize the "function of necessity" for their family and society as a whole. Often this is what motivates retirement upon reaching retirement age, especially among women. However, the current economic and social changes, such as a decrease in family size, an increase in life expectancy and growing insecurity in the labor market, reduce the opportunities for economic support traditionally provided by families to their elderly relatives. Therefore, the social security systems existing in western countries assume the responsibility of providing the economic security of senior people today.

Economic measures of social support include:

- social payments and benefits;

- protection of living standards by providing various forms of compensation;

- assistance to the unemployed;

- social services.

The adequacy of pensions is obviously measured by their ability to prevent poverty in old age, which is a key task according to the relevant documents [16], but

\begin{tabular}{lcccccc}
\hline Indicator & 2013 & 2014 & 2015 & 2016 & 2017 & 2018 \\
\hline $\begin{array}{l}\text { Budget expenditures of the Russian Federation on social } \\
\text { support, billion rubles }\end{array}$ & 170.8 & 151.5 & 153.5 & 162.0 & 172.1 & 215.8 \\
\hline $\begin{array}{l}\text { Budget implementation of the Pension Fund of Russia, } \\
\text { billion rubles }\end{array}$ & 6388 & 6159 & 7127 & 7625 & 8260 & 8333 \\
\hline $\begin{array}{l}\text { The share of social support in pension payments, \% } \\
\text { Source: data from the Federal State Statistics Service (Analytical portal) [5]. }\end{array}$ & & & & & & \\
\hline
\end{tabular}

Table 4.

The correlation of the total social support expenditures and pension payments in Russia. 


\begin{tabular}{|c|c|c|c|c|c|c|c|c|c|}
\hline Indicators & 2010 & 2011 & 2012 & 2013 & 2014 & 2015 & 2016 & 2017 & 2018 \\
\hline \multicolumn{10}{|c|}{ Distribution of the employed by age groups in \% of the total number } \\
\hline Aged 60-72 & 3.8 & 4.2 & 4.6 & 4.7 & 4.8 & 5.1 & 5.3 & 5.6 & 5.9 \\
\hline \multicolumn{10}{|c|}{ The unemployment rate among pensioners in $\%$ of the total number } \\
\hline Pensioners & 7.4 & 7.9 & 7.9 & 12.9 & 14.4 & 14.0 & 13.7 & 15.6 & 15.5 \\
\hline \multicolumn{10}{|c|}{$\begin{array}{l}\text { The average annual number of people employed in the economy by type of activity in \% of the total } \\
\text { number }\end{array}$} \\
\hline \multicolumn{10}{|c|}{ Source: data from the Federal State Statistics Service (Russia in Figures) [6]. } \\
\hline
\end{tabular}

Table 5.

Analysis of some indicators in the Russian labor market.

not limited to this. The most important task is also to maintain a socially acceptable standard of living for pensioners, i.e. the possibility for retirees to use the public goods to which they are accustomed. Therefore, it would be interesting to compare the budget expenditures of the Russian Federation for social support and the amount of pension funds paid to Russian pensioners over the past 6 years (Table 4).

The analysis of Table 4 shows that the level of social support provided by the state is low, which is also confirmed by the fact that the share of pensioners in the poor population is $12-13 \%$, which is why Russian pensioners are trying to continue their labor activities. However, not all pensioners have such a work history, health and profession to receive sufficient income after retirement. Analysis of the labor market shows that the proportion of working pensioners is growing (Table 5). ${ }^{1}$

The data in the Table 5 allow us to draw the following conclusions:

1. The number of working pensioners for the period under review increased 1.55 times;

2. The unemployment rate among pensioners for the period under review increased 2.1 times; $^{2}$

The number of highly qualified specialists employed in the economy is growing.

Unfortunately, there is no individual statistics on the number of pensioners belonging to the category of intellectual employees; however, it can be assumed that their number will also increase, since this category of pensioners has great prospects for employment.

Russia has recently launched a lot of activities for pensioners at the municipal level - holding various classes free of charge: physical therapy exercises, computer literacy training, foreign language learning, musical instrument training, etc. Nevertheless, pensioners do not seek to retire. This is especially evident in the field of creative and intellectual work among scholars, university and college instructors, performers, artists, etc.

\footnotetext{
1 From 1928 to 2018, the retirement age in Russia was established as follows: 55 years for women and 60 years for men. Since 2018, the retirement age has been gradually increasing to 60 years for women and 65 for men.

${ }^{2}$ Pensioners are considered as unemployed when they are registered with the public employment services, i.e. are looking for a job and ready to start working.
} 


\section{Conclusion}

The analysis showed a rather low level of financial security among Russian pensioners and not too high level of state social support, however, some other factors affecting the maintenance of decent lifestyle by senior people should be taken into account:

- any person needs to be aware of their "usefulness" to society;

- senior people have accumulated a large amount of knowledge, they have the tools to put this knowledge into practice and need to use this potential;

- communication with other age groups of the population prevents them from focusing on their problems only, but rather broadens their horizons and promotes socialization.

Thus, when analyzing the problems of pensioners, it is necessary to take a differentiated approach to solving them, considering not only economic indicators, but also the mentality of the society, the pensioners' sphere of activity, their qualifications and accumulated experience. Sate social support should take these factors into account when creating jobs, including those for pensioners, in an effort to create conditions for older people to continue to benefit society. Therefore, the government of the Russian Federation has the following objectives in the near future:

1. To develop and improve the mandatory funded pension due to the small incomes of Russian citizens that prevent them from accumulating substantial savings;

2. To develop and propose optimal investment mechanisms and tools for citizens with the aim of creating additional sources of income;

3. To improve social support for citizens, also by creating jobs that allow the use of the pensioners' experience and knowledge in such fields as education and training, caring for the sick and infirm, etc.

4. To ensure the confidence of Russian citizens in the pension system by creating predictable rules for its improvement.

The current stage of the Russian pension scheme implementation lacks a Pension System Development Concept. The major document that regulates the pension system improvement is called Development Strategy for the Pension System of the Russian Federation up to 2030 and has been worked out based on the Decree of the President of the Russian Federation \# 597 On Measures Concerning Implementation of State Social Policy, dated May 7, 2012 and based on a number of regulatory documents that legislatively set forth the standards established by the Government, like the increased retirement age, etc. However, these documents cannot be attributed to the Development Concept since they lack specific targets. 


\section{Author details}

Elena Ivanovna Kulikova

Financial University under the Government of the Russian Federation, Moscow, Russia

*Address all correspondence to: kulikovae@yandex.ru

\section{IntechOpen}

(C) 2020 The Author(s). Licensee IntechOpen. This chapter is distributed under the terms of the Creative Commons Attribution License (http://creativecommons.org/licenses/ by/3.0), which permits unrestricted use, distribution, and reproduction in any medium, provided the original work is properly cited. (c) BY 


\section{References}

[1] Economic Inequalities in Old Age. United Nations. Available from: https:// www.un.org/development/desa/age ing/wp-content/uploads/sites/24/2016/ 08/Briefing-Paper_Economic-Inequa lities_Final.pdf

[2] The International Covenant on Economic, Social and Cultural Rights. Available from: https://www.un.org/ru/ documents/decl_conv/conventions/pac tecon.shtml

[3] Milton F. Capitalism and Freedom (40th anniversary ed.). Chicago: University of Chicago Press; 2002. pp. 182-189. ISBN: 978-0-226-26421-9

[4] Strategy for the development of the pension system of the Russian Federation until 2030. Available from: https://ohranatruda.ru/news/files/Stra tegiya_pensii_2030.pdf [Accessed: 05 February 2020]

[5] Analytical Portal. Available from: https://investfunds.ru/market-statistics/ [Accessed: 05 February 2020]

[6] The collection "Russia in figures". Available from: http://www.perepis2020.ru/wps/wcm/connect/rosstat_ main/rosstat/ru/statistics/publications/ catalog/doc_1135075100641 [Accessed: 05 February 2020]

[7] Federal law "on amendments to certain legislative acts of the Russian Federation on the appointment and payment of pensions" dated 03.10.2018 N 350-FZ (latest version). Available from: http://www.consultant.ru/ document/cons_doc_LAW_308156/ [accessed: 05 February 2020]

[8] Danilov YA, Abramov AE, Buklemishev OV. Reform of financial markets and non-banking financial sector. Moscow: Center for strategic research of the Ranepa; 2017. p. 100. Available from: https://publications.hse. ru/mirror/pubs/share/direct/208372568 (in Russian)

[9] Information and analytical commentary "NPF market Trends":

Department of collective investments of the Central Bank of the Russian Federation/based on operational data of specialized depositories for the IV quarter of 2019. Moscow. 2019. Available from: https://cbr.ru/ Collection/Collection/File/27274/NPF market_trends_2019-q4.pdf [Accessed: 05 February 2020]

[10] Shvandar KV, Anisimova AA. Ensuring a socially acceptable level of pension protection for citizens: world practice. National Interests: Priorities and Security. 2018;14(8):1551-1565

[11] Schulz HJ, Carrin G. The Role of Savings and Pension Systems in Maintaining Living Standards in Retirement. The Journal of Human Resources. 1972;7(3):343-365

[12] Disney R, Emmerson C, Wakefield $M$. Pension reform and saving in Britain. Oxford Review of Economic Policy. 2001;17(1):70-94. DOI: $10.1093 /$ oxrep/17.1.70

[13] Guseva Irina A, Kulikova Elena I, Rebelsky Nikolai M, Arkhipova Lidia S. Functional Improvement of Non-state Pension Funds as Mechanism of Investment in Russian Economy. Journal of Reviews on Global Economics. 2018;(7):457-463

[14] OECD Core Principles of Private Pension Regulation. Available from: https://www.oecd.org/pensions/CorePrinciples-Private-Pension-Regulation. pdf [Accessed: 05 February 2020]

[15] Abramov AE. Institutional investors in the world: features of activity and development policy. In: 2 books: kN.1/A. E. Abramov; nauch. ed. Moscow: 
Alternatives to Serve the Interests of Russian Pensioners DOI: http://dx.doi.org/10.5772/intechopen.92163

publishing house "Delo” Ranepa; 2014. 544 p (in Russian)

[16] European Union Pension Systems Adequate and Sustainable? European Parliament. Available from: https:// docplayer.net/29060828-Europeanunion-pension-systems-adequate-andsustainable.html [Accessed: 05 February 2020] 



\title{
Called to Plan: Changing Patterns and Perceptions of Retirement for Australian and New Zealand Faith-Based Ministers
}

\author{
Bernadene Erasmus and Peter John Morey
}

\begin{abstract}
The rising tide of aging citizens globally suggests a compelling argument for increasing understanding of factors impacting retirement. Factors such as health and finance have been identified as principal, but these results generally apply to homogenous groups with little reference to the impact of culture and tradition. This study adopted an ex post-facto, cross-sectional, self-reporting survey from working faith-based ministers in Australia and New Zealand to ascertain personal and professional factors affecting retirement perception in specific context including results for age-related differences. Results from four areas of foci show participants generally regarded retirement as a positive season. They were, however, less confident about their preparedness and mostly dissatisfied with the level of planning for retirement. Significant differences were noted in age-related groups with health and financial considerations constituting the primary differences. Increased understanding of changing patterns and perceptions for specific groups including age differences, potentially aids the response of state and society to the ageing phenomenon.
\end{abstract}

Keywords: retirement, culture, faith-based, planning, well-being

\section{Introduction}

The global rise in the aging population means that older individuals account for increasing numbers in society. Coupled with the challenge of providing social services for an aging population with an increased life expectancy, comes the equally significant impact of aging citizens who historically now face more years in retirement than earlier generations [1]. Statistics from the Australian Bureau of Standards [2] indicate that of 9.4 million people who had registered employment in the age group 45 years and more, approximately 3.6 million individuals (38\%) were retired. The average age for recent retirees in Australia is 61.4 years [2]. The importance of enhancing the wellbeing of such a significant portion of the population becomes a necessary consideration for society in general.

These considerations advance a forceful argument for identifying factors which will lessen the burden of an aging demographic on social services and potentially improve the wellbeing of people in the retirement phase of their lives. In order to do so, it is important to guard against a perception of retirees as a homogenous group. 
This has potential to construct stereo-typical profiles which may be useful for statistical purposes but limit the formation of a multi-focal lens essential for increased insight into a complex phenomenon.

To demonstrate the value of inquiry into specific groups with distinctive characteristics of culture and tradition, a sample of working faith-based ministers in Australia and New Zealand was surveyed to gauge their perception of retirement. By studying this sample, we were able to include lesser researched factors such as spirituality and the influence of a call to ministry. In addition, this sample ascribes to a culture of holistic well-being which regards fostering physical and mental health as part of their faith-based culture. Lifestyle programs such as the Complete Health Improvement Program (CHIP), are widely embraced and have demonstrated significant success in addressing age-related conditions. Results have been published in several international medical journals.

Traditionally, faith-based ministers did little or no planning for retirement and generally retired with no real estate. We were interested to know how these factors impacted on the way contemporary ministers viewed retirement. Consequently, this chapter will explore factors that influence the perception of the retirement season of faith-based ministers in a specific context in the hope it will spark conversation about other related contexts.

The discussion will start with a brief reference to theories on aging and the need for extending inquiry to address the lesser researched phenomenon of spirituality and its impact on retirement planning in order to increase insight into retirement patterns. This will be followed by a section on the methodology employed and an outline of the survey instrument. Results from the data analysis will then be considered with reference to demographics and an outline of the personal and professional factors which impact the retirement perceptions of this sample. We will find out just how prepared these individuals think they are for retirement; whether they view the prospect as positive; how satisfied they are with their planning and when they are thinking about retiring. The results will be collated and differences between younger and older cohorts highlighted. In the discussion section, there will be a focus on the significance of the findings of this study, its limitations and concluding remarks. The results of this study are delivered within the context of a definition of retirement which breaks with some traditional concepts of retirement as an end of career phase. The orientation of the study regards aging as a positive experience and offers valuable insights into contemporary retirement perception as a season of continued active contribution and growth.

\section{Considerations from the literature}

As society begins to grapple with the burgeoning impact of aged citizens on many levels of contemporary living, research into aging and retirement grows across a wide spectrum of issues relating to the phenomenon. In fact, aging has been attributed to a growing impetus on the development of social gerontology [3]. Representations of aging are discussed in academic literature through the lens of various gerontological theories. Early theories include Erikson [4], the Disengagement Theory of Cumming and Henry [5], and subsequent theories such as the Activity Theory [6], Successful Aging [7], Schroots [8] and Atchley's Continuity Theory [9]. Some criticism of theories such as those relating to Rowe and Kahn's Successful Aging, question the lack of consideration given to aspects including historical and cultural context and social relationships. The current study is situated within a distinctive historical and cultural context with the aim of identifying factors relating to cohorts within a specific group with strong cultural and traditional values. 
Previous studies have identified a diverse range of factors impacting on retirement timing [10]. Trends in relation to retirement in the literature are discussed by authors like Cahill et al. [11] who forecast an increase in bridge-jobs. For this purpose, issues generally identified in research as impacting on retirement, such as finance and health, will be incorporated but variables specific to context such as spirituality will also be included.

The current study adopts an orientation in which retirement is regarded as a continued phase of career and personal development. Although the value of traditional gerontological theories is acknowledged, there is agreement with the view of Lytle et al. [12] that most of these theories do not consider retirement as a career stage nor is account taken of the diversity of cultural and historical perspectives.

In its statistics on retirement, the ABS [2] rates financial security as a principal factor influencing decisions to retire. The financial context within which retirement decisions are made, however, has grown increasingly complex [1]. In fact, it is contended that the individual will be challenged to navigate a way through retirement financial planning without professional aid. It is not surprising then that results from research studies indicate financial resources as a primary consideration relative to retirement [13].

Considerations of health in relation to retirement receive significant focus in the literature. In Australia, health is rated as a primary factor in most aspects relating to retirement [2]. Health costs, however, are increasingly becoming a challenge, constituting increasing pressure on financial planning for retirement [1]. In addition to physical health, the literature also proposes factors relating to mental health such as the role of social connections which is suggested as a buffer to age-related degeneration [14].

This inquiry aims to demonstrate the need for caution when generalizing statistics in relation to age-related study. Although most of the literature on retirement considered in this study referred to retirees as homogenous groups, studies which do account for age difference found significant differences in anticipated reasons for retirement [13]. Respondents in the 55-64 years old cohort, for example, rated financial security higher than their peers in the younger age bracket. Other studies suggest that there are age-related differences in planning for retirement. Jimenez et al. [15] found that the age differences in their Spanish study, however, are representative of a relatively young cohort. The population of contemporary aging spans more than five decades but represents a confusing concept in that there is cultural non-consensus about labels and definition particularly pertaining to the last two decades of aging [16]. While cognizance is taken of this issue, the current study will identify two clearly designated groups as younger (less than 50 years of age) and older (more than 50 years of age). This may suggest a limitation of this study but also creates the opportunity for future study to investigate possible differences within sub-groups of these age brackets.

In recent decades there has been an increasing focus in the literature on aspects of the nature of spirituality. Despite this growing interest, however, there has been little work on spirituality and gerontology even though spirituality is not a marginal consideration but according to Atchley, "a vital context for understanding aging" [16]. Indeed, Pargament [17] proposes that spirituality is a distinctive motivation and process. Yet although spirituality and religiosity have been offered as distinct constructs [18], most research has been undertaken from a religion-orientated standpoint [16].

Diverse perceptions and definition of religion and spiritualty have led to ongoing conversation with some ambiguity still pervading academic texts. There are instances where the terms are used interchangeably or in other cases embedded in either concept with resulting definition at times so encompassing or so narrowly focused, as to become confusing. This makes for an intriguing issue which unfortunately falls 
outside the scope of this chapter. For the purposes of this discussion, the authors have taken the standpoint that religion and spirituality be understood in relation to the worldview of the participants. The concept of religion as a parasol of beliefs formed from a specific interpretation of theology has come under change in recent years. The participants in this study do not reject traditionally institutionalised religion. Spirituality as operated collectively (The Call) finds expression in individual response (A Call). Spirituality for the individual is perceived as a dynamic and on-going experience in which individuals grow and mature in their understanding of their faith journey and in relationship to a divine being. Definition, therefore, becomes context orientated. This is not to deny that "the nature of spiritual experience is complex and does not lend itself to simplistic concepts of measure" [16]. It is offered as a conceptual framework for understanding the response of the participants.

As such incorporation of spirituality within the concept of aging and retirement that reflects the perception of the participants becomes a necessary inquiry. In this study, the role of spirituality and particularly the impact of the concept of a Call, which is understood as a personal invocation to serve others, will be included in the conversation. Atchley [16] proposes that for many individuals service itself is regarded as a spiritual experience. The Call to service for individuals may transcend organizational commitment and is perceived as divinely derived [19]. These considerations point to a need indicated in the literature for new studies linking retirement planning with spirituality and the identification of specific differences in retirement planning [20].

The identification of factors influencing pre-retirement planning potentially illuminates patterns of adjustment to retirement [21]. Indeed, increased understanding of retirement and aging is significant in contributing to the response of organizations, government and society to the aging phenomenon [22]. The current inquiry will highlight the importance of considering retirement planning in specific context and of the need for differentiating between age cohorts. It is hoped that additional insight into lesser researched factors impacting aging, such as spirituality will add value to the conversation. These results will indicate the evolving trends for specific groups with strong cultural and traditional ties and suggest insights to enhance understanding for management strategies.

\section{Methodology}

This study adopted an ex post facto cross-sectional self-reporting survey to collect data from working Seventh-day Adventist Ministers in Australia and New Zealand. Permission to access these ministers along with the ministers' email addresses was provided from the respective regional employers. In 2018, emails were sent to these ministers outlining the purpose of the survey and inviting them to participate in the survey questionnaire via an online survey hosted by SurveyMonkey. This online link was left open for one month with three reminders sent to the potential respondents during this time. About 570 emails were sent to ministers and 228 interacted with the online survey, representing a 40\% response rate.

Ethics approval for this research study was obtained from the Avondale Human Research Ethics Committee (Project number 2018.3).

\subsection{The survey instrument}

The survey questionnaire included 11 democratic and professional work-related questions. These included items on training, length of service, type of ministry and location. This was followed by survey items relating to personal and professional factors from which 14 personal and professional scales were constructed. All items 
were rated on a 4-point Likert scale in which respondents were asked to rate their agreement with the positive stem statement from minimally to substantially.

\subsubsection{Scales}

Physical Health was measured by an overall physical health scale. Cognitive health was measured by the Cognitive Function scale [23] which measures the individual respondent's perception of their cognitive ability.

Respondent's perception of psychological stress and depression was measured using items adapted from the K10 [24] with two additional items specifically related to ministry. Items for the Wellbeing scale were adapted from the survey on Retirement Intentions for Australian Medical Practitioners [13] with the addition of one item relating specifically to the call to ministry. Items measuring the respondent's perception about aging, were adapted from the Anxiety About Ageing Scale [25].

The items for the Work Centrality scale, measuring the importance of work, were sourced from the Work Centrality Questionnaire [26] which included additional questions relating specifically to the centrality of ministry and calling.

Four items from the Retirement Resource Inventory (RRI) Financial scale, measured the respondents' view of their financial status in relation to retirement and their perception about current and future support. These items were adapted from the RRI [23]. Five items from the Retirement Resource Inventory Social scale, based on the RRI [23] measures a wide range of perceived social support.

The items from the Personal Resilience scale measure the individual's response to their perception of their ability to deal with the challenges of life. The items are adapted from the RRI [23] with two additional items sourced from The Resilience Advantage [27]. The items from the Future Pathway subscale (FS), [28] were included to measure the respondents' perception of their ability to plan and accomplish goals.

The survey also included four items relating to aspects of ministry as a career and the divine 'calling' of their work. It was anticipated that these items would generate a Calling scale. Factor and scale reliability analysis of these items indicated that these items do not generate a single scale. These separate items were, however, included in the analysis of the data.

The respondents were then asked to rate the following items on a 4-point Likert scale:

How prepared for retirement do you think you are?

How confident are you that retirement will be a positive season of your life?

How satisfied are you with your planning for retirement?

What factors will determine the timing of your retirement?

\section{Data analysis}

\subsection{Demographics}

Of the 228 respondents, $93.36 \%$ were male, $92.11 \%$ were married, $68.58 \%$ completed their primary theological training in Australia and $76 \%$ of the respondents were presently serving in Australia and 24\% in New Zealand. In terms of employment history, 35.96\%, 29.39\%, 18.86\%, 11.84\% and 3.95\% had been employed as ministers for 0-10 years, 10-20 years, 20-30 years, 30-40 years and $40+$ years respectively. 
In terms of present service orientation, $52.86 \%$ serve in an urban church; $25.11 \%$ serve in a rural church; $16.30 \%$ have some type of administration role while the rest $(5.72 \%)$ have other roles. For this cohort, $11.85 \%$ reported that they worked less than 40 hours per week, 39.47\% reported they worked $40-49 \mathrm{~h}$ per week, $32.89 \%$ reported that they worked $50-59 \mathrm{~h}$ per week and $15.79 \%$ reported they worked $60+\mathrm{h}$ per week.

Of the respondents $7.46 \%$ were aged under 29 years, $15.35 \%$ were $30-39$ years, $24.12 \%$ were $40-49$ years, $28.07 \%$ were $50-59$ years, $12.72 \%$ were $60-64 \%$ and $12.8 \%$ were $65+$ years. This resulted in $46.93 \%$ of the respondents being less than 50 years of age and $53.70 \%$ being $50+$ years of age. This two group age division was adopted in the univariate calculations. To facilitate reading, the two groups will be referred to as the younger set (less than 50 years of age) and the older set (fifty years and older).

\subsection{Personal and professional factors impacting the retirement experience}

All factor scales had a reliability coefficient (Cronbach's alpha) greater than 0.75 (Table 1) which supported the use of these scales in this context. These factors were measured on a 4-point Likert scale signifying any reported mean greater than 2.5 indicates that the majority of the respondents agreed or strongly agreed with positive statements relating to the respective factors (Figure 1).

There were significant differences by age group for some of these factors (Table 1). As expected, those aged less than 50 years reported significantly higher values of physical health than those aged 50 plus years $[(t)=3.250, p=0.001]$. What is interesting, however, is the absolute values of the Physical Health scale means (2.752 and 2.324) appear relatively low which was not expected given the importance of living and promoting a healthy lifestyle within the mission of the Seventh-day Adventist church. In terms of psychological stress, despite the significant difference $[(t)=2.673, p=0.008]$, the mean scale values (1.579 and 1.416) suggest the majority of both the younger and older age group were coping relatively well with the stress generated by their profession. In contrast to physical health, it was the younger set that was more likely to register greater levels of stress in their professional role than the older set.

There was also a significant difference between the younger and the older age group in terms of their perceived retirement finance resources $[(t)=2.665, p=$ $0.008]$. Even though the older set reported higher mean RRI-Finance ratings than their younger colleagues, a mean of 2.334 compared to 2.060 , their absolute values being below 2.500 would suggest that a large percentage of the ministers are still not comfortable with their present retirement financial resources.

\subsection{Perceptions of the preparation for and the retirement experience}

This study focused on four aspects of current ministers' perceptions of retirement: preparedness for retirement; viewing retirement as a positive season; satisfaction with planning for retirement; factors influencing timing of retirement. Most of the ministers were quite confident that retirement would be a positive season of their life $(M=3.067, \mathrm{SD}=0.762)$. They were, however, less confident that, at this point in time, they were prepared for retirement $(\mathrm{M}=2.585, \mathrm{SD}=$ $0.787)$ and were not satisfied with their planning for retirement $(\mathrm{M}=2.380, \mathrm{SD}=$ 0.904). There were significant age group differences in the perceptions of preparation aspects for retirement. The older set was significantly more confident that they were prepared $[(\mathrm{t})=-3.322, \mathrm{p}=0.001]$ and satisfied with their planning for retirement $[(t)=-3.067, p=0.002]$ than their younger colleagues. 
Called to Plan: Changing Patterns and Perceptions of Retirement for Australian...

DOI: http://dx.doi.org/10.5772/intechopen.91901

\begin{tabular}{|c|c|c|c|c|c|c|c|c|}
\hline \multirow[t]{2}{*}{$\begin{array}{l}\text { Scale-item/Age } \\
\text { group }\end{array}$} & & \multicolumn{2}{|c|}{$\begin{array}{l}\text { Combined } \\
\text { data }\end{array}$} & \multicolumn{2}{|c|}{$\begin{array}{l}\text { Less than } 50 \\
\text { years }\end{array}$} & \multicolumn{2}{|c|}{$50+$ years } & \multirow[b]{2}{*}{$\begin{array}{l}\mathrm{p}- \\
\text { value }\end{array}$} \\
\hline & Alpha & Mean & SD & Mean & SD & Mean & SD & \\
\hline Physical Health & $\mathrm{Na}$ & 2.558 & 0.274 & 2.752 & 1.004 & 2.324 & 0.926 & $.001^{*}$ \\
\hline $\begin{array}{l}\text { Cognitive } \\
\text { Function }\end{array}$ & .828 & 3.680 & 0.406 & 3.655 & 0.450 & 3.701 & 0,363 & .406 \\
\hline $\begin{array}{l}\text { Psychological } \\
\text { Stress }\end{array}$ & .906 & 1.493 & 0.441 & 1.579 & 0.501 & 1.416 & 0.366 & $.008^{*}$ \\
\hline Wellbeing & .872 & 2.950 & 0.504 & 2.930 & 0.523 & 2.968 & 0.489 & .172 \\
\hline $\begin{array}{l}\text { Anxiety About } \\
\text { Ageing }\end{array}$ & .750 & 2.558 & 0.274 & 2.593 & 0.230 & 2.528 & 0.305 & .097 \\
\hline Work Centrality & .782 & 3.352 & 0.484 & 3.302 & 0.477 & 3.396 & 0.487 & .172 \\
\hline RRI - Financial & .799 & 2.208 & 0.726 & 2.060 & 0.734 & 2.334 & 0.698 & $.008^{*}$ \\
\hline RRI - Social & .726 & 2.935 & 0.726 & 2.997 & 0.681 & 2.880 & 0.763 & .256 \\
\hline $\begin{array}{l}\text { Personal } \\
\text { Resilience }\end{array}$ & .772 & 3.056 & 0.356 & 3.083 & 0.382 & 3.033 & 0.332 & .321 \\
\hline Future Scale & .826 & 3.203 & 0.425 & 3.233 & 0.439 & 3.176 & 0.412 & .350 \\
\hline $\begin{array}{l}\text { Career: Marked } \\
\text { by external } \\
\text { reward, following } \\
\text { Other careers }\end{array}$ & $\mathrm{Na}$ & 1.974 & 0.950 & 2.043 & 0.888 & 1.915 & 1.001 & .346 \\
\hline $\begin{array}{l}\text { Career: } \\
\text { Contributing to } \\
\text { the Greater good }\end{array}$ & $\mathrm{Na}$ & 3.226 & 0.787 & 3.228 & 0.7278 & 3.224 & 0.839 & .972 \\
\hline $\begin{array}{l}\text { Career: A divine } \\
\text { calling for a } \\
\text { Specific purpose }\end{array}$ & $\mathrm{Na}$ & 3.145 & 0.855 & 3.260 & 0.904 & 3.046 & 0.904 & .078 \\
\hline $\begin{array}{l}\text { Career: A divine } \\
\text { calling that lasts a } \\
\text { lifetime }\end{array}$ & $\mathrm{Na}$ & 3.625 & 0.629 & 3.623 & 0.637 & 3.626 & 0.637 & .978 \\
\hline
\end{tabular}

*A significant difference in age group perceptions at the 0.05 level

Table 1.

Personal and Professional factors scale means: a comparison between respondents aged less than 50 years and those aged 50 plus years.

\subsection{Predictors of ministers perceptions of retirement}

To explore the potential relationships between the outcome measures: How prepared for retirement do you think you are? How confident are you that retirement 


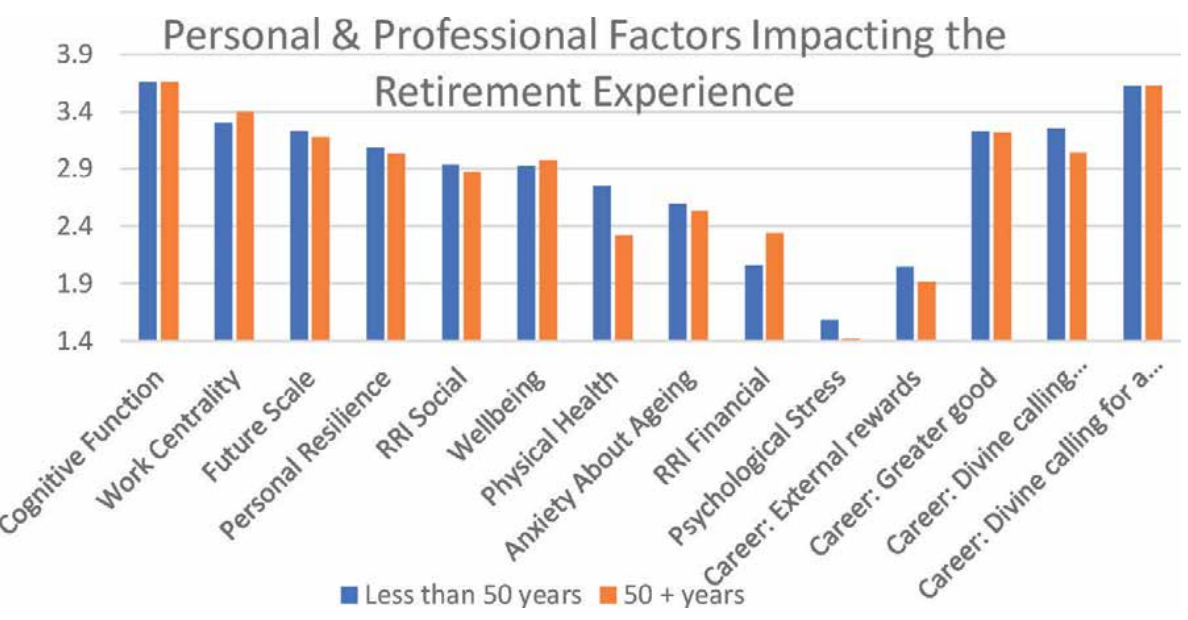

Figure 1.

Personal and professional factors impacting the retirement experience.

will be a positive season in your life? How satisfied are you with your planning for retirement? and the 14 personal and professional factors (Table 1), backward multiple regression was carried out (Tables 2-4). The resulting residual distributions were near normal. Further, the collinearity statistic 'VIP' was calculated to test for multicollinearity between the respective predictors. All VIP values were less than 10 , indicating that multicollinearity does not appear problematic [29].

\subsubsection{How prepared did they think they were for retirement?}

For the younger set, regression analysis generated a single significant factor model that explained $33.3 \%$ of the variance in ministers' perception of how prepared they thought they were for retirement. The single predictor of this sample of ministers' perception of their preparedness for retirement was their rating of the Retirement Resource Inventory: Finance $(\beta=+0.459)$. The higher they rated their financial retirement resources, the more they felt they were prepared for retirement. For the older set, regression analysis generated a two significant factor model that explained $29.8 \%$ of the variance in ministers' perception of how prepared they

\begin{tabular}{|l|r|r|r|r|}
\hline Personal \& Professional factors & R Square & Beta & t value & Sig. \\
\hline Age less than 50 years & 0.333 & & & \\
\hline Retirement Resources: Finance & & 0.459 & 4.623 & $<.001^{*}$ \\
\hline Physical Health & & -0.196 & -1.931 & .057 \\
\hline Cognitive Functioning & & -0.197 & -1.906 & .060 \\
\hline Age 50+ years & 0.298 & & & \\
\hline Retirement Resources: Finance & & 0.394 & 3.947 & $<.001^{*}$ \\
\hline Psychological Stress & & -0.216 & -2.173 & $.033^{*}$ \\
\hline $\begin{array}{l}\text { A calling which is divinely inspired and is } \\
\text { directed to a specific purpose for a set time }\end{array}$ & & 0.160 & 1.711 & .091 \\
\hline *Significant at the .005 level & & & \\
\hline
\end{tabular}

Table 2.

Predictors of ministers' perception of how prepared they thought they were for retirement. 
Called to Plan: Changing Patterns and Perceptions of Retirement for Australian...

DOI: http://dx.doi.org/10.5772/intechopen.91901

\begin{tabular}{|l|r|r|r|c|}
\hline Personal \& Professional factors & R Square & Beta & t value & Sig. \\
\hline Age less than 50 years & 0.414 & & & \\
\hline Physical Health & & -0.350 & -3.677 & $<.001^{*}$ \\
\hline Wellbeing & & 0.260 & 2.667 & $.009^{*}$ \\
\hline $\begin{array}{l}\text { A calling which is divinely inspired and is } \\
\text { directed to a specific purpose for a set time }\end{array}$ & & 0.211 & 1.913 & $.023^{*}$ \\
\hline $\begin{array}{l}\text { A vocation which allows for personal } \\
\text { fulfilment and development and } \\
\text { contributes to the greater good }\end{array}$ & & 0.185 & 2.028 & $.046^{*}$ \\
\hline $\begin{array}{l}\text { A career, not unlike other careers, where } \\
\text { achievement is marked by external reward } \\
\text { and career advancement }\end{array}$ & & -0.174 & -1.913 & .060 \\
\hline Age 50+years & & & & \\
\hline Anxiety about Ageing (Reverse) & & 0.500 & 5.936 & $<.001^{*}$ \\
\hline Retirement Resources: Financial & & 0.362 & 4.293 & $<.001^{*}$ \\
\hline
\end{tabular}

*Significant at the .005 level

Table 3.

Predictors of ministers' perception of how confident they are that retirement will be a positive season of their lives.

\begin{tabular}{|c|c|c|c|c|}
\hline Personal \& Professional factors & R Square & Beta & t value & Sig. \\
\hline Age less than 50 years & 0.574 & & & \\
\hline Retirement Resources: Finance & & 0.586 & 7.459 & $<.001^{*}$ \\
\hline Physical Health & & -0.238 & -0.361 & $.003 *$ \\
\hline $\begin{array}{l}\text { A vocation which allows for personal } \\
\text { fulfilment and development and } \\
\text { contributes to the greater good }\end{array}$ & & 0.177 & 2.361 & $.021 *$ \\
\hline Age 50+years & 0.475 & & & \\
\hline Retirement Resources: Finance & & 0.525 & 6.150 & $<.001 *$ \\
\hline Future Scale & & 0.294 & 3.505 & $.001 \%$ \\
\hline $\begin{array}{l}\text { A career, not unlike other careers, where } \\
\text { achievement is marked by external } \\
\text { reward and career advancement }\end{array}$ & & 0.148 & 1.785 & .078 \\
\hline Retirement Resource: Social & & 0.144 & 1.708 & .091 \\
\hline
\end{tabular}

Table 4.

Predictors of ministers' perception of how satisfied they were with their planning for retirement. 
thought they were for retirement. The strongest predictor was their rating of the Retirement Resource Inventory: Finance $(\beta=+0.394)$, followed by Psychological Stress $(\beta=-0.216)$. The negative Beta values indicate that the higher they rated psychological stress, the less their perception of their preparedness for retirement (Table 2).

\subsubsection{Did they think retirement would be a positive season of their lives?}

For those ministers aged 50 years and less, regression analysis generated a three significant factor model that explained $41.4 \%$ of the variance in ministers' perception of how confident they are that retirement will be a positive season of their lives. The strongest predictor was their rating of their physical health $(\beta=-0.350)$. The higher they rated their physical health, the less they felt that retirement would be a positive season of their life. The next strongest predictors were Wellbeing ( $\beta=$ 0.260 ), followed by their rating of "ministry is a calling which is divinely inspired and is directed to a specific purpose for a set time" $(\beta=0.211)$. This was followed by their rating of "ministry is a vocation which allows for personal fulfillment and development and contributes to the greater good" $(\beta=0.185)$. For those ministers aged $50+$ years, regression analysis generated a two significant factor model that explained $42.6 \%$ of the variance in older ministers' perception of how confident they are that retirement will be a positive season of their lives. The strongest predictor was their rating of the anxiety about aging $(\beta=+0.362)$. Because of the reverse orientation of this factor, this result indicates that the less ministers are anxious about aging, the more they will see retirement as a positive season of their life. The next significant predictor was their rating of the Retirement Resource Inventory: Finance factor $(\beta=+0.362)$ (Table 3$)$.

\subsubsection{Were they satisfied with planning for retirement?}

For ministers aged 50 years and less, regression analysis generated a three significant factor model that explained $57.4 \%$ of the variance in younger ministers' perception of how satisfied they were with their planning for retirement. The strongest predictor was their rating of the Retirement Resource Inventory: Finance $(\beta=+0.586)$ factor, followed by their self-reported Physical Health rating ( $\beta=$ -0.238 ) and then their rating of "ministry is a vocation which allows for personal fulfillment and development and contributes to the greater good" ( $\beta=0.177)$ factor. For the older set, regression analysis generated a two significant factor model that explained $47.5 \%$ of the variance in older ministers' perception of how satisfied they were with their planning for retirement.

The strongest predictor was their rating of the Retirement Resource Inventory: Finance $(\beta=+0.362)$, followed by their Future Scale-pathway rating $(\beta=+0.294)$ (Table 4).

\section{Factors influencing timing of retirement}

There were some differences between the age groups in terms of importance of some factors in timing of retirement (Figure 2). The less than 50 years group more often reported that impairment of cognitive function would be a significant factor in the timing of retirement than the $50+$ group $[t(196)=2.013, p=0.045]$. The less than 50 years group also more often reported that an understanding they had completed the task God had called them to do, would be a significant factor in the timing of retirement than the $50+$ group $[\mathrm{t}(194)=2.492, \mathrm{p}=0.014]$. 


\section{Factors Influencing the Timing of Retirement}

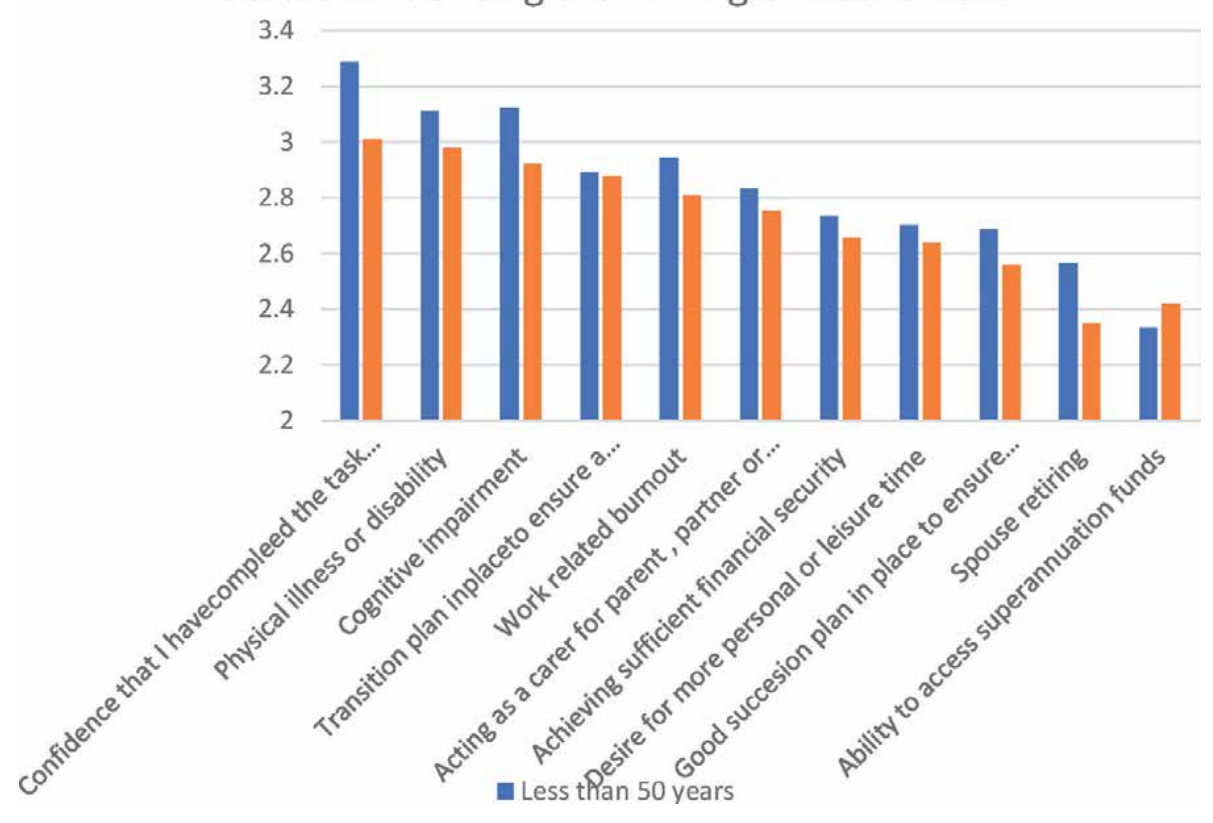

Figure 2.

Mean ratings of the respective factors influencing the timing of retirement across the two age groups.

The relative importance of the respective factors influencing the timing of retirement for the two age groups was strikingly similar (Table 5). The differences, when they occurred were minor. The pattern of the ranking of both age groups followed the same overall trend: The most important factor in terms of retirement timing was the response to God' calling. The next important set of factors was: health assessment; both physical and psychological. This was followed by the need to retire to help others. Then with a ranking of 7/11 came 'achieving sufficient financial security'. All the other factors were considered of lesser importance in determining timing of retirement.

In terms of ranking differences across the age groups the less than 50 years group ranked cognitive impairment above physical illness whereas for the $50+$ years the order was reversed; a difference that was not predicted. The timing of the retirement of their spouse had little impact on the retirement timing for most of the ministers. Ministers within the 50+ age group ranked timing of spouse retirement lower than the younger years age group. In fact, the older age group ranked timing of spouse retirement as the least important of the respective timing of retirement factors presented to them.

\section{Discussion}

At the start of this chapter, we noted that an aging population now implies that a significant portion of society faces an historically increased number of years in retirement. Not only will an increasing percentage of citizens in developed countries live longer, but they will experience a more complex retirement dynamic as they come to realize. "Aging is not what it used to be..." [30].

This phenomenon has far-reaching implications for society in general and calls for an informed response at local and state level. A multidimensional approach to retirement necessitates a multi-focal lens in which it is recognized that retirees are not a homogenous group. This necessitates consideration of culture specific 


\begin{tabular}{|c|c|c|c|c|c|c|c|c|c|}
\hline \multirow{2}{*}{$\begin{array}{l}\text { Scale-Item/Age } \\
\text { Group }\end{array}$} & \multicolumn{3}{|c|}{ Combined data } & \multicolumn{3}{|c|}{ Less than 50 years } & \multicolumn{3}{|c|}{$50+$ years } \\
\hline & Rank & Mean & SD & Mean & SI & Rank & Mean & SD & Rank \\
\hline $\begin{array}{l}\text { Confidence that I } \\
\text { have completed the } \\
\text { task God has called } \\
\text { me to do* }\end{array}$ & 1 & 3.144 & 0.761 & 3.288 & 0.767 & 1 & 3.019 & 0.737 & 1 \\
\hline $\begin{array}{l}\text { Physical illness or } \\
\text { disability }\end{array}$ & 2 & 3.040 & 0.670 & 3.111 & 0.643 & 3 & 2.981 & 0.689 & 2 \\
\hline $\begin{array}{l}\text { Cognitive } \\
\text { impairment* }\end{array}$ & 3 & 3.015 & 0.690 & 3.122 & 0.684 & 2 & 2.924 & 0.685 & 3 \\
\hline $\begin{array}{l}\text { Transition plan in } \\
\text { place to ensure a } \\
\text { positive retirement } \\
\text { experience }\end{array}$ & 4 & 2.882 & 0.649 & 2.890 & 0.721 & 5 & 2.876 & 0.583 & 4 \\
\hline $\begin{array}{l}\text { Work Related } \\
\text { Burnout }\end{array}$ & 5 & 2.871 & 0.794 & 2.943 & 0.844 & 4 & 2.809 & 0.748 & 5 \\
\hline $\begin{array}{l}\text { Acting as a carer for } \\
\text { a parent, partner or } \\
\text { child or grand child }\end{array}$ & 6 & 2.789 & 0.740 & 2.833 & 0.825 & 6 & 2.752 & 0.661 & 6 \\
\hline $\begin{array}{l}\text { Achieving sufficient } \\
\text { financial security }\end{array}$ & 7 & 2.692 & 0.778 & 2.733 & 0.790 & 7 & 2.657 & 0.769 & 7 \\
\hline $\begin{array}{l}\text { Desire for more } \\
\text { personal or leisure } \\
\text { time }\end{array}$ & 8 & 2.666 & 0.722 & 2.700 & 0.785 & 8 & 2.638 & 0.666 & 8 \\
\hline $\begin{array}{l}\text { Good succession } \\
\text { plan in place } \\
\text { to ensure continuity }\end{array}$ & 9 & 2.618 & 0.733 & 2.688 & 0.788 & 9 & 2.557 & 0.680 & 9 \\
\hline $\begin{array}{l}\text { Partner/spouse } \\
\text { retiring }\end{array}$ & 10 & 2.450 & 0.778 & 2.566 & 0.821 & 10 & 2.349 & 0.723 & 11 \\
\hline $\begin{array}{l}\text { Ability to access } \\
\text { superannuation } \\
\text { funds }\end{array}$ & 11 & 2.381 & 0.754 & 2.333 & 0.778 & 11 & 2.423 & 0.733 & 10 \\
\hline
\end{tabular}

*A significant difference in age group perceptions at the 0.05 level

Table 5.

Factors influencing timing of retirement: a comparison between respondents aged less than 50 years and those aged 50 plus years.

impacting factors and awareness of contextual influence in age-differentiated approaches in order to gain in-depth insight into the retirement phenomena.

We hoped to make a contribution to the conversation on retirement by selecting a specific group of participants with strong cultural and traditional ties to 
illustrate that in addition to the well-documented impacting factors of health and finance, additional influencers have significant impact on the way retirement is viewed. In addition, we sought the response of two age identified groups (50 years and younger, 50 years and older) to identify age related differences in perception to retirement. This group of working Seventh-day Adventist ministers in Australia and New Zealand presented an opportunity to address lesser researched areas such as the impact of spirituality and a calling as well as an opportunity to study a group with a culture of adherence to promoting a holistic lifestyle as part of their faith beliefs. In addition, it became clear from a reading of the literature that there is only limited research into perceptions of contemporary ministers of religion [31].

Response to the inquiry into personal and professional factors impacting retirement indicated that these ministers rated their cognitive health very highly. They also gave regard for wellbeing, personal resilience and their ability to plan for the future relatively high ratings. The centrality of their work was also highly rated, a result common to other careers where work is regarded to some degree as a 'calling' [13]. Anxiety about aging was rated in mid-range. In terms of financial and social resources for retirement, the social component was rated highly but in contrast, the financial component received a low rating.

Most of the minsters saw their career as a divine life-long calling which may be divided into periods of particular focus but always with a service orientation. Their retirement was not seen as an end of ministry but rather a time to move into a different ministry orientation. This view finds commonality with the central premise of Atchley's Continuity Theory (1989) in which older adults seek to preserve and maintain previous lifestyle patterns, identities and values.

There were age group differences with the older set rating their psychological stress significantly lower and their financial retirement resources significantly higher than their younger colleagues. As predicted, the younger set rated their physical health significantly higher than their older colleagues.

The study focused on three principal aspects of retirement: How prepared participants thought they were for retirement?; Whether they thought retirement would be a positive season?; Whether they were satisfied with their planning for retirement? Most of the ministers were quite confident that retirement would be a positive season of their life but please see further discussion below. They were, however, less confident that they were prepared for retirement and were not satisfied with their planning for retirement. Even though both age groups ranked these elements of retirement in the same order, the younger set were less confident about each element than the older ministers.

For both age groups, financial resources were the strongest positive predictor of perceptions of preparedness for retirement. For the younger set, psychological stress was a negative predictor of preparedness; the greater the stress the less prepared for retirement they felt. Whether an increase in psychological stress was linked to a perception that retirement may come earlier than planned or that stressed ministers generated more negative assessments of their present situation, needs further exploration.

Predictors of retirement as a positive season of life were different for the two age groups; something that was not foreseen. For the $50+$ years age group the two predictors were financial resources, as expected, and their anxiety about aging. The less anxious they were about aging, the more often they perceived that retirement would be a positive season of their life. In contrast, for the younger group, financial resources were not a predictor that retirement would be a positive season of their life. Rather the following factors were considered significant: wellbeing; a perception that calling to ministry was for a specified task and the view that ministry 
allowed for personal development and fulfillment. These are personal and professional factors that could be seen to enhance ministers' ability to cope well with life changes in general, so it seems reasonable to have these factors associated with a positive view of retirement. For the younger set, physical health was a negative predictor of the retirement phase. Why? A possible explanation could be that younger ministers who felt physically healthy now, anticipated poorer health in the future and thus perceived that retirement will be less positive.

Associated with the ministers' perception of their preparedness for retirement, is their perception of satisfaction with their planning. For both age groups perception of retirement finance resources, once again, consistently predicted their satisfaction with retirement planning. As predicted, the older set's perception of their future orientation was a positive predictor of satisfaction with their retirement planning. What is interesting, however, is that this is not a predictor for the younger ministers, perhaps suggesting that retirement planning often does not become a focused activity until ministers reach the $50+$ years age range. For the younger set, the perception that their career was a vocation which allows for personal fulfillment and development was also a predictor of satisfaction with their retirement planning. This may indicate that for these ministers, personal development orientation includes planning for the future. The awareness that a positive retirement experience necessitates taking personal responsibility for being prepared for this eventuality demonstrates an emerging trend for ministers. The weight given to personal development may also suggest that the younger group regard retirement as an opportunity to continue growing and contributing to the welfare of others.

Results from considering the responses of participants in terms of timing for retirement reiterate the importance of inquiry into specific context. The most significant factor influencing the timing of retirement was not finances but for both age groups, confidence that they had completed God's calling. Results like this have important implications for management strategies. It is clear that it cannot be assumed that monetary considerations constitute the primary decider of when individuals in this study will retire. These participants have indicated that they will continue working until they feel certain they have accomplished the task for which they were called, irrespective of financial considerations but dependent on health status.

Although both age groups placed a high premium on health when it came to decisions about when to retire, the younger group gave pre-eminence to cognitive health, while the older group considered physical health as more important. Either way, the high ranking given to health is potentially further evidence that contemporary faith-based ministers are entering a new era where they are aware of the necessity of taking personal responsibility for their personal and professional wellbeing. This may be illustrated by the increasing enrollment and growth of Seventh-day Adventist holistic health programs in the USA, Australia and New Zealand.

Limitations of this study include that it only accessed ministers from one faith-based community. Even so, it is expected that this career specific study could have application to other faith-based ministers but additional studies with different faith-based ministers are needed to test this expectation. The sample size though reasonable for the Australian and New Zealand Seventh-day Adventist faith-based community, comprise a relatively small number of ministers. This limited the ability of the study to explore differences within the sample in terms of such characteristics as ministry type, location, training, gender and a larger range of age groups. Finally, the data obtained was constrained by the researchers' questionnaire framework. Factors that influence ministers' perceptions of retirement outside this framework can and should be explored by studies adopting a qualitative research orientation. 


\section{Conclusion}

The rising tide of baby boomers entering retirement, coupled with global challenges of the aging phenomena, has focused the spotlight on employee preparation for retirement. Faith-based ministers, who traditionally followed a line that God would take care of them in retirement, have entered a new era in which, while not negating their faith beliefs, are advocating for a more active role in preparing for the retirement phase. Insights gained from this study will make a valuable contribution to the general understanding of retirement as a 'comma' and no longer as a 'full-stop' in an individual's life span. Results from this study show that individuals who envisage a retirement season in which, service for the greater good is continued in some form, are more likely to experience a positive retirement life phase. In particular, these results focus on the importance of understanding factors impacting retirement in specific context, strengthening the argument that retirees cannot be regarded as a homogeneous group. Results have indicated evolving patterns even within cohorts of the aging population. It is proposed that the adoption of a multifocal lens to view retirement has the potential to enhance organizational management strategies, interpersonal connectivity and intrapersonal growth and wellbeing. By increasing the wellbeing of retirees in the community, a potentially significant resource will be unleashed to augment ever-increasing social needs. This study presents an opportunity to incorporate insight from specific context into macro-evolving patterns; shifting perception of aging and retirement as an increasing burden on society to one of a potential positive contributory resource. This surely constitutes a step in the right direction.

\section{Acknowledgements}

The authors acknowledge the contribution of Dr Peter Williams and Dr Bruce Manning to the work of this research.

\section{Conflict of interest}

The authors declare that they are not aware of any conflict of interest in the course of conducting this research.

\section{Thanks}

A note of thanks to Lynelle Waring for editorial assistance. 


\section{Author details}

Bernadene Erasmus* and Peter John Morey

Avondale University College/Charles Sturt University, Cooranbong, NSW, Australia

*Address all correspondence to: berasmus@bigpond.com

\section{IntechOpen}

(C) 2020 The Author(s). Licensee IntechOpen. This chapter is distributed under the terms of the Creative Commons Attribution License (http://creativecommons.org/licenses/ by/3.0), which permits unrestricted use, distribution, and reproduction in any medium, provided the original work is properly cited. (cc) BY 


\section{References}

[1] Feldman DC, Beehr TA. A threephased model of retirement decision making. American Psychologist. 2011;66(3):1-27

[2] Australian Bureau of Statistics. Retirement. 2017. Available from: ABS. gov.au/ausstats/abs@nnsf/mf/4149.0

[3] Ejechi EO. Social activities of retired nigerian academics: The applicability of the continuity theory. Activities, Adaption \& Aging. 2015;29(10):64-76

[4] Erikson EH. Childhood and Society. New York: W.W. Norton; 1950

[5] Cumming E, Henry W. Growing Old: The Process of Disengagement, New York. Basic Books; 1961

[6] Havighurst RJ. Developmental Tasks and Education. McKay: New York; 1948

[7] Rowe J, Kahn R. Successful ageing. The Gerontologist. 1997;37(4):433-440

[8] Schroots JJ. Theoretical developments in the psychology of aging. The Gerontologist. 1996;36(6): 742-748

[9] Atchley RC. A continuity theory of normal aging. The Gerontologist. 1989;29(2):183-190

[10] Fisher GG, Chaffee DS, Sonnega A. Retirement timing: A review and recommendations for future research. Work, Aging \& Retirement. 2016;2(2):230-261

[11] Cahill KE, Giandrea MD, Quin JF. Retirement patterns from career employment. The Gerontologist. 2006;46(4):514-523

[12] Lytle MC, Foley PF, Cotter EW. Career and retirement theories: Relevance for older workers across cultures. Journal of Career Development. 2015;42(3):185-198
[13] Wijeratne C, Earl JK, Peisah C, Luscombe GM, Tibbertsma J. Professional and psychological factors affecting the intention to retire of Australian medical practitioners. Medical Journal of Australia.

2017;206(5):209-214

[14] Shariffian N, Gruhn D. The differential impact of social participation and social support on psychological well-being: Evidence from the Wisconsin Longitudinal Study. International Journal of Aging and Human Development. 2018;88(2):107-126

[15] Jimenez I, Chiesa R, Topa G. Financial planning for retirement: Age-related differences among Spanish workers. Journal of Career Development. 2018;46(5):550-566

[16] Atchley RC. Spirituality and Aging. Maryland: John Hopkins; 2009. p. 149

[17] Pargament K. Spirituality as an irreducible human motivation and process. The International Journal for the Psychology of Religion. 2013;23(4):271-281

[18] Dy-Liacco GS, Piedmont RL, Murray-Swank NA, Rodgerson TE, Sherman MF. Spirituality and religiosity as cross-cultural aspects of human experience. Psychology of Religion and Spirituality. 2009;1(1):35-52

[19] Netting FE, O'Connor MK, Yancey G. Belief systems in faith-based human service programs. Journal of Religion \& Spirituality in Social Work: Social Thought. 2006;25(3-4):261-286

[20] Earl JK. The contribution of spirituality to the process of retirement. Journal of Management, Spirituality and Religion. 2015;7(3):223-240

[21] Richardson V, Kilty KM. Adjustment to retirement: Continuity vs 
discontinuity. International Journal of Aging and Human Development. 1991;33(2):151-169

[22] Breheny M, Griffiths Z. "I had a good time when I was young." Interpreting descriptions of continuity among older people. Journal of Aging Studies. 2017;41:36-43

[23] Leung C, Earl JK. Retirement resources inventory: Construction, factor structure and psychometric properties. Journal of Vocational Behaviour. 2012;81:171-182

[24] Kessler R, Andrews G, Colpe L. Short screening sales to monitor population prevalences and trends in non-specific distress. Psychological Medicince. 2000;32:959-976

[25] Lasher K, Faulkender P.

Measurement of adding anxiety: Development of the anxiety about aging scale. International Journal of Aging and Human Development. 1993;37:247-259

[26] Lim G, Ng L. Early retirement and bridge employment intentions among older workers in Singapore. Asia Pacific Journal of Management. 1997;14:185-210

[27] Siebert A. The Resilience Advantage. Berrett-Koehler: California; 2005

[28] Snyder C, Harris C, Anderson J, Holleran S, Irving L, Sigmon S. The will and the ways: Development and validation of an individual-difference measurement of hope. Journal of Personality and Social Psychology. 1991;6:570-585

[29] Ho R. Handbook of Univariate and Multivariate Data Analysis and Interpretation with SPSS. Chapman \& Hall: New York; 2006

[30] Watkins D. Spiritual formation of older persons in a postmodern context.
Journal of Religion, Spirituality and Aging. 2009;22(1-2):1-11

[31] Davey J. What influences retirement decisions? Social Policy Journal New Zealand. 2008;33:110-125 


\title{
Lifestyles, Health, and Life Satisfaction among the Portuguese Seniors
}

\author{
Aida Isabel Tavares
}

\begin{abstract}
This chapter focuses on the interaction between lifestyles, health, and life satisfaction of Portuguese seniors. The aim of the analysis is to find the main determinants of health and life satisfaction and to verify the importance of lifestyle variables as determinants of health and life satisfaction. We used data collected by the National Health Survey of 2014 and estimated two ordered probits. The main results show that not all lifestyle variables are meaningful in explaining selfassessed health and life satisfaction. The determinants of the health status include education and income; however, it can be assumed that overall good health, family, or close people and income contribute to life satisfaction. A general profile of the Portuguese seniors is provided; however, the results obtained here are changing as a new scenario is emerging, generation $\mathrm{X}$ enters old age.
\end{abstract}

Keywords: lifestyles, self-assessed health, life satisfaction, elderly, Portugal

\section{Introduction}

Portugal is one of the oldest countries in Europe and the country where the share of older people is growing faster [1]. The life expectancy at birth, in 2018, was 78.3 and 84.5 years for males and females, respectively, and it slightly improved between 2014 and 2018 (Table 1); life expectancy at 65 years old was 18.2 and 22.0 years for males and females, respectively, in 2018. Nevertheless, Portuguese elderly enjoy short healthy life years when they reach 65 , while males may enjoy 7.8 healthy years, women enjoy 6.9 according to data for 2018 (Table 1). Summing up, older Portuguese people live long lives but without quality of life.

Portuguese are in general less satisfied with life (OECD, Eurobarometer since 1973, Gesis [3-5]; European Social Survey [6-8]). When people are asked "on the whole how are you satisfied with your overall life," Portuguese tend to report lower level of satisfaction than the other Europeans (Figure 1).

The same trend about life satisfaction is found in other older people. Based on SHARE survey (SHARE [9]), wave 6, comparing life satisfaction across several European countries, the share of Portuguese seniors reporting life dissatisfaction (levels $0-3$ in a scale of $0-10$, where 0 means completely dissatisfied and 10 completely satisfied) is nearly $7.5 \%$ of the respondents, while the average for the remaining countries in the sample is about $2.8 \%$. 


\begin{tabular}{lcccccc}
\hline & Life expectancy at birth & \multicolumn{2}{c}{ Life expectancy at 65 } & \multicolumn{2}{c}{ Healthy life years at 65 } \\
\hline & $\mathbf{2 0 1 4}$ & $\mathbf{2 0 1 8}$ & $\mathbf{2 0 1 4}$ & $\mathbf{2 0 1 8}$ & $\mathbf{2 0 1 4}$ & $\mathbf{2 0 1 8}$ \\
\hline Total & 81.3 & 81.5 & 20.2 & 20.3 & 6.2 & 7.3 \\
\hline Males & 78.0 & 78.3 & 18.1 & 18.2 & 6.9 & 7.8 \\
\hline Females & 84.4 & 84.5 & 21.9 & 22.0 & 5.6 & 6.9 \\
\hline
\end{tabular}

Source: Eurostat Database [2].

Table 1.

Aging information about Portugal.

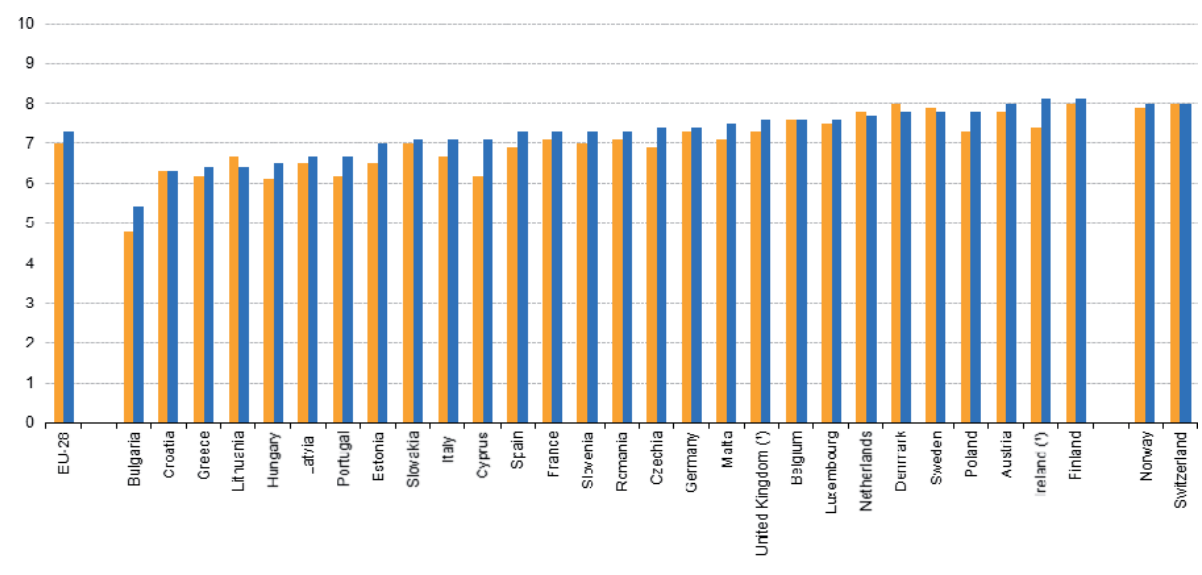

$-2013=2018$

(1) Provisional

Figure 1.

Overall life satisfaction mean rating by country, 2013 and 2018. Source: Eurostat database (online data code: il_pw01) [7].

Health and life satisfaction have long been studied, as well as their interconnectedness [10-13]. The determinants of health and life satisfaction, in general, coincide [14-17], and they include demographics, socioeconomic status, overall well-being (physical and mental health), and social interactions.

People's lifestyle choices also influence health $[18,19]$ and life $[20]$, as is frequently pointed out by the WHO [21-23]. Healthy lifestyles mean eating a healthy diet with vegetables and fruit, no smoking, not drinking excessively, and being involved in some regular exercising. These are means to prevent the onset of non-communicable chronic diseases such as cardiovascular diseases, diabetes, cancer, and dementia.

Older Portuguese people and issues in relation to their health, life satisfaction, and lifestyles have so far received limited research interest; however, there are some studies that approached these issues. Concerning health, Portuguese people aged 65 and over tend to report satisfaction with their health [24], and the determinants are aligned with international studies, i.e., as people get older, especially women, who are less educated and those of low socioeconomic status, tend to report lower health status [25].

Studies on life satisfaction, happiness, or well-being in Portugal indicate that despite socioeconomic status being a relevant determinant, other factors such as social networks and personal relationships are also related to health and provide more important explanatory factors $[25,26]$. At the beginning of the twenty-first century, Delhey [27] revealed that the three most relevant factors for quality of life in Portugal were primarily health, followed by family and then income. 


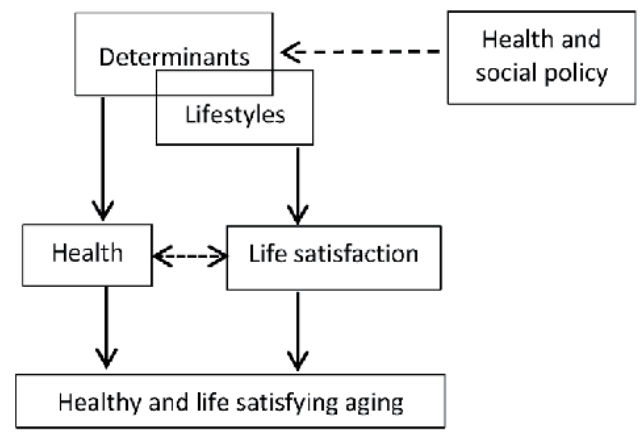

Figure 2.

Conceptual mapping.

Focusing on diet, Santos et al. [28] found that overall seniors tend to have a lowquality diet, especially single males, but those living in rural areas were more likely to have a better diet.

We do not know much about alcohol intake and smoking of older people in Portugal. Bosque-Prous [29] using SHARE data showed that Portugal has a high prevalence of hazardous drinking.

This is different when it comes to the use of tobacco. Older people do not display a profile of heavy smokers, and as they get older, they tend to smoke less [30], but smokers tend to consume more alcoholic beverages and have a poorer diet [31]. Physically active seniors tend to delay aging decay [32], and, based on SHARE data, the prevalence of inactive older people is very high in Portugal, and that may be due to depression, low social support, and low life satisfaction [33].

This chapter has two aims. First is to describe and analyze the lifestyles, health, and life satisfaction of Portuguese seniors. Second is to identify the main explanatory factors of self-assessed health and life satisfaction of Portuguese seniors.

The conceptual map framing our analysis is presented in Figure 2. Lifestyle choices are based on health and life satisfaction, so we consider determinants such as demographics, socioeconomic status, and health related issues. These determinants influence the way older Portuguese people perceive their health and create their awareness about life satisfaction. Once the most important determinants have been identified, then policy measures may be designed to improve the general health, overall well-being, and life satisfaction by influencing those determinants.

This chapter proceeds with the description of the methods used to achieve the aims of the analysis. Then the results are presented, and, at the end, the discussion outlines some systemic as well as personal changes to influence unhealthy lifestyle choices.

\section{Method}

\subsection{Data and sample}

Data used for the analysis performed in this chapter is collected by the National Health Survey (NHS) of 2014 [34]. This survey is a community-based cross-sectional study. Data collected is obtained according to a multistage stratified and cluster sampling. The obtained sample represents the Portuguese population. The survey was implemented in the whole country between September and December 2014, and it included 18,204 people aged 15 year or over, who are not institutionalized. The questions in the survey covered four thematic areas: health status, healthcare, health 
Who Wants to Retire and Who Can Afford to Retire?

\begin{tabular}{|c|c|c|}
\hline Group of variables & $\begin{array}{l}\text { Independent } \\
\text { variables }\end{array}$ & Description \\
\hline \multirow[t]{2}{*}{ Demographic variables } & Male & Dummy variable. Takes value 1 is male and 0 otherwise \\
\hline & Age group & $\begin{array}{l}\text { Age is grouped in five classes: } 65-69,70-74,75-79,80-84 \text {, } \\
\text { and }>85 \text { years old }\end{array}$ \\
\hline \multirow[t]{11}{*}{$\begin{array}{l}\text { Socioeconomic } \\
\text { variables }\end{array}$} & Education & $\begin{array}{l}\text { Education is grouped in five levels of education } \\
\text { corresponding to the number of complete schooling } \\
\text { years and levels, } 0,6,9,12,15 \text {, and } 17 \text {, where } 0 \text { means no } \\
\text { schooling and } 17 \text { means university degree }\end{array}$ \\
\hline & Marital status & \\
\hline & Single & Takes value 1 if person is single and 0 otherwise \\
\hline & Married & Takes value 1 if person is married and 0 otherwise \\
\hline & Divorced & Takes value 1 if person is divorced and 0 otherwise \\
\hline & Widow & Reference category \\
\hline & Income & $\begin{array}{l}\text { Income is grouped in five classes which represent the } \\
\text { quintile of net monthly income per equivalent adult }\end{array}$ \\
\hline & $\begin{array}{l}\text { Degree of } \\
\text { urbanization }\end{array}$ & $\begin{array}{l}\text { Measures the degree of urbanization where individual } \\
\text { lives }\end{array}$ \\
\hline & Urban & $\begin{array}{l}\text { Takes value } 1 \text { if degree of urbanization is defined as urban } \\
\text { and } 0 \text { otherwise }\end{array}$ \\
\hline & Rural & $\begin{array}{l}\text { Takes value } 1 \text { if degree of urbanization is defined as rural } \\
\text { and } 0 \text { otherwise }\end{array}$ \\
\hline & Moderate & Reference category \\
\hline \multirow[t]{7}{*}{$\begin{array}{l}\text { Health and physical } \\
\text { conditions variables }\end{array}$} & Chronic diseases & $\begin{array}{l}\text { Takes value } 1 \text { if person suffers from at least } 1 \text { chronic } \\
\text { disease and } 0 \text { otherwise }\end{array}$ \\
\hline & $\begin{array}{l}\text { Limitation to } \\
\text { general activity }\end{array}$ & $\begin{array}{l}\text { Measures the limitation of people to perform their daily } \\
\text { life and general activities }\end{array}$ \\
\hline & Severe & $\begin{array}{l}\text { Takes value } 1 \text { if individual reports severe limitation and } 0 \\
\text { otherwise }\end{array}$ \\
\hline & Moderate & $\begin{array}{l}\text { Takes value } 1 \text { if individual reports moderate limitation } \\
\text { and } 0 \text { otherwise }\end{array}$ \\
\hline & None & Reference category \\
\hline & $\begin{array}{l}\text { Depression } \\
\text { indicator }\end{array}$ & $\begin{array}{l}\text { Takes values } 0-9 \text { where } 0 \text { means no feelings of depression } \\
\text { and } 12 \text { means feelings of (i) useless or guilty, an/or (ii) } \\
\text { lack of interest in usual things, and/or (iii) depressed or } \\
\text { lack of courage almost every day and } 0 \text { otherwise }\end{array}$ \\
\hline & BMI & $\begin{array}{l}\text { Body mass index is calculated by the ratio of weight over } \\
\text { the square of height }\end{array}$ \\
\hline \multirow[t]{5}{*}{ Lifestyle variables } & Physical activity & Number of days per week doing physical exercise \\
\hline & Smoking & $\begin{array}{l}\text { Takes value } 1 \text { if respondent smokes daily or occasionally } \\
\text { and } 0 \text { otherwise }\end{array}$ \\
\hline & Eating vegetables & $\begin{array}{l}\text { Takes value } 1 \text { if respondent eats fruit and/or salads } \\
4-7 \text { days per week and } 0 \text { otherwise }\end{array}$ \\
\hline & $\begin{array}{l}\text { Eat unhealthy } \\
\text { food }\end{array}$ & $\begin{array}{l}\text { Takes value } 1 \text { if respondent has eaten fast food or } \\
\text { precooked meals in the previous day and } 0 \text { otherwise }\end{array}$ \\
\hline & Alcohol drinking & $\begin{array}{l}\text { Takes value } 1 \text { if respondent drinks alcoholic drinks } \\
\text { frequently during the week and } 0 \text { otherwise }\end{array}$ \\
\hline
\end{tabular}

Table 2.

Description of independent variables. 
determinants, and income and health expenses. The NHS 2014 is a survey harmonized and regulated in EU level [Commission Regulation (EU) No 141/2013].

Our sample includes all respondents older than 65 years from the whole of the country, that is, 5701 Portuguese seniors. Analyses were conducted with Stata version 15 (StataCorp LP, College Station, Texas, USA).

\subsection{Variables}

The dependent variables of this study are the self-assessed health (henceforth $\mathrm{SAH}$ ) and the life satisfaction (henceforth LS). The independent variables comprise a set of independent variables grouped in demographic, socioeconomic, health and physical conditions, and lifestyle variables. These variables are described in the following.

\subsubsection{Dependent variables}

\subsubsection{Life satisfaction}

Life satisfaction is captured by the survey question "are you satisfied with your life?". The answers are graded in a scale $1-7$ where 1 means "I completely disagree" being satisfied and 7 means "I completely agree" being satisfied.

\subsubsection{Self-assessed health}

Self-assessed health is obtained from the question "how do you evaluate your health status." The answer varies from 1 to 5 , where 1 means "very bad" and 5 means "very good."

\subsubsection{Independent variables}

The independent variables are grouped in demographic, socioeconomic, health and physical conditions, and lifestyle variables which are described in Table 2.

\section{Results}

\subsection{Descriptive analysis}

The majority of the respondents assessed their health as being less than reasonable and about $35 \%$ reported a bad or very bad health status (Table 3 ).

\begin{tabular}{lcc}
\hline & Number & $\%$ \\
\hline 5 very good & 108 & 1.90 \\
\hline 4 good & 787 & 13.81 \\
\hline 3 fair & 2817 & 49.45 \\
\hline 2 bad & 1443 & 25.33 \\
\hline 1 very bad & 542 & 9.51 \\
\hline
\end{tabular}

Table 3.

Self-assessed health. 
Who Wants to Retire and Who Can Afford to Retire?

\begin{tabular}{lcc}
\hline & Number & $\%$ \\
\hline 1 completely dissatisfied & 232 & 4.13 \\
\hline 2 & 690 & 12.28 \\
\hline 3 & 437 & 7.78 \\
\hline 4 fairly satisfied & 496 & 8.83 \\
\hline 5 & 1317 & 23.43 \\
\hline 6 & 2.1 & 37.37 \\
\hline 7 completely satisfied & 348 & 6.19 \\
\hline
\end{tabular}

Table 4.

Life satisfaction.

\begin{tabular}{|c|c|c|c|c|c|}
\hline $\begin{array}{l}\text { Demographic } \\
\text { variables }\end{array}$ & Number & $\%$ & Socioeconomic variables & Number & $\%$ \\
\hline \multicolumn{3}{|l|}{ Gender } & \multicolumn{3}{|l|}{ Education } \\
\hline Male & 2,215 & 38.9 & No schooling & 1,941 & 34.1 \\
\hline Female & 3,486 & 61.2 & 6 years (basic school 1st level) & 2,938 & 51.5 \\
\hline \multicolumn{3}{|c|}{ Age group (group>10) } & $\begin{array}{l}9 \text { years (basic school 2nd } \\
\text { level) }\end{array}$ & 353 & 6.2 \\
\hline $65-69$ & 1,533 & 26.9 & 12 years (secundary school) & 189 & 3.3 \\
\hline $70-74$ & 1,319 & 23.1 & $\begin{array}{l}15 \text { years (post-secondary } \\
\text { school) }\end{array}$ & 14 & 0.3 \\
\hline 75-79 & 1,259 & 22.1 & 17 years (college degree) & 265 & 4.7 \\
\hline $80-84$ & 979 & 17.2 & Marital status & & \\
\hline \multirow[t]{2}{*}{$>85$} & 611 & 10.7 & Single & 363 & 6.4 \\
\hline & & & Married & 2,913 & 51.1 \\
\hline \multicolumn{3}{|c|}{ Health and physical condition variables } & Widow & 2,132 & 37.4 \\
\hline \multicolumn{3}{|l|}{ Chronic diseases } & Divorced & 293 & 5.1 \\
\hline Yes & 4,922 & 86.4 & Income & & \\
\hline No & 778 & 13.6 & 1st Q & 1,368 & 24.0 \\
\hline \multicolumn{3}{|c|}{ Limitations to general activity } & 2nd Q & 1,534 & 26.9 \\
\hline Severe & 1,062 & 18.6 & 3rd Q & 1,174 & 20.6 \\
\hline Minor & 2,415 & 42.4 & 4th Q & 867 & 15.2 \\
\hline None & 2,222 & 39.0 & 5 th $\mathrm{Q}$ & 758 & 13.3 \\
\hline \multicolumn{3}{|c|}{ Depression indicator } & \multicolumn{3}{|l|}{ Number of people in household } \\
\hline No sign & 2,544 & 45.2 & 1 & 2,330 & 40.9 \\
\hline At least one sign & 3,089 & 54.8 & 2 & 2,749 & 48.2 \\
\hline $\begin{array}{l}\text { Body mass index } \\
(\mathrm{BMI})>26.6\end{array}$ & 2,759 & 50.0 & +3 & 426 & 10.9 \\
\hline \multicolumn{3}{|c|}{ Lifestyle variables } & \multicolumn{3}{|l|}{ Degree of urbanization } \\
\hline \multicolumn{3}{|l|}{$\begin{array}{l}\text { Number days } \\
\text { physical activity }\end{array}$} & Urban & 1,563 & 27.4 \\
\hline None & 4,523 & 79.5 & Moderate urban & 1,689 & 29.6 \\
\hline Some days & 1,169 & 20.5 & Rural & 2,449 & 42.9 \\
\hline
\end{tabular}


Lifestyles, Health, and Life Satisfaction among the Portuguese Seniors DOI: http://dx.doi.org/10.5772/intechopen.93250

\begin{tabular}{|c|c|c|c|c|c|}
\hline $\begin{array}{l}\text { Demographic } \\
\text { variables }\end{array}$ & Number & $\%$ & Socioeconomic variables & Number & $\%$ \\
\hline \multicolumn{6}{|l|}{ Smoking } \\
\hline Yes & 266 & 4.67 & Number of respondents & & 5,701 \\
\hline No & 5,433 & 95.33 & & & \\
\hline \multicolumn{6}{|c|}{$\begin{array}{l}\text { Eating vegetables (4-7 days/ } \\
\text { week) }\end{array}$} \\
\hline Yes & 5,369 & 94.33 & & & \\
\hline No & 323 & 5.67 & & & \\
\hline \multicolumn{6}{|c|}{ Eating unhealthy food (previous day) } \\
\hline Yes & 2,316 & 40.88 & & & \\
\hline No & 3,349 & 59.12 & & & \\
\hline \multicolumn{6}{|c|}{ Drinking alcohol (frequency) } \\
\hline $\begin{array}{l}\text { Never or not } \\
\text { frequently }\end{array}$ & 3,815 & 67.00 & & & \\
\hline Frequently & 1,882 & 33.30 & & & \\
\hline
\end{tabular}

Table 5.

Descriptive statistics for independent variables.

Concerning life satisfaction, most Portuguese seniors reported being satisfied with life. Around $67 \%$ of respondents evaluated their life satisfaction at the highest levels (levels 5-7) of satisfaction (Table 4). So, despite the generally negative reporting of their health status, seniors are satisfied with life.

The description of the independent variables is presented in Table 5.

Most of the seniors surveyed are women, and about half of them are aged between 65 and 75 years old. More than half of the surveyed seniors have a very low level of education; the majority are married, and, in general, they receive very low levels of income.

Concerning the health and physical conditions, the large share of older Portuguese suffer from chronic diseases and/or from depression; they face some minor form of physical limitation to perform daily tasks, and they are overweight.

Finally, a great number of the older population do not do any exercise, but they do not smoke either; a great number report having eaten unhealthy food in the previous day, but a very large number of older people eat fruit and salad daily or very often; almost $30 \%$ of the respondents stated to drink alcohol very frequently such as every day or 5-6 times a week.

The correlation between binary variables is given by the tetrachoric correlation. This was computed for lifestyle variables (Table 6). None of the correlations is very

\begin{tabular}{lccc}
\hline & Smoking & Eating vegetables & Eating unhealthy food \\
\hline Smoking & 1.00 & & \\
\hline Eating vegetables & -0.22 & 1.00 & \\
\hline Eating unhealthy food & 0.03 & -0.003 & 1.00 \\
\hline Drinking alcohol & 0.24 & 0.05 & -0.06 \\
\hline
\end{tabular}

Table 6.

Correlation of lifestyle variables. 


\begin{tabular}{|c|c|c|c|c|}
\hline & \multicolumn{2}{|c|}{ Self-assessed health } & \multicolumn{2}{|c|}{ Life satisfaction } \\
\hline & Coef & $\mathbf{P}>\mathbf{z}$ & Coef & $\mathbf{P}>\mathrm{z}$ \\
\hline \multicolumn{5}{|l|}{ Demographic variables } \\
\hline Male & -0.035 & 0.369 & -0.085 & 0.018 \\
\hline Age & -0.004 & 0.744 & 0.052 & 0.000 \\
\hline \multicolumn{5}{|l|}{ Socioeconomic variables } \\
\hline Education & 0.032 & 0.000 & -0.002 & 0.685 \\
\hline \multicolumn{5}{|l|}{ Marital status } \\
\hline Single & -0.033 & 0.715 & 0.229 & 0.008 \\
\hline Married & -0.211 & 0.005 & 0.288 & 0.000 \\
\hline Widow & -0.048 & 0.529 & 0.110 & 0.119 \\
\hline Income & 0.098 & 0.000 & 0.072 & 0.000 \\
\hline No. of people in household & 0.018 & 0.401 & 0.044 & 0.028 \\
\hline \multicolumn{5}{|l|}{ Degree urbanization } \\
\hline Urban & 0.060 & 0.149 & 0.036 & 0.351 \\
\hline Rural & -0.064 & 0.085 & 0.023 & 0.505 \\
\hline \multicolumn{5}{|l|}{ Health condition variables } \\
\hline Chronic diseases & -0.756 & 0.000 & -0.134 & 0.003 \\
\hline \multicolumn{5}{|l|}{ Limitations } \\
\hline Severe & -1645 & 0.000 & -0.502 & 0.000 \\
\hline Moderate & -0.808 & 0.000 & -0.232 & 0.000 \\
\hline Depression indicator & -0.149 & 0.000 & -0.190 & 0.000 \\
\hline BMI & -0.004 & 0.268 & 0.009 & 0.011 \\
\hline \multicolumn{5}{|l|}{ Lifestyle variables } \\
\hline Smoking & 0.243 & 0.001 & -0.042 & 0.546 \\
\hline Eating vegetables & 0.039 & 0.564 & 0.100 & 0.114 \\
\hline Eating unhealthy food & 0.047 & 0.140 & 0.107 & 0.000 \\
\hline Drinking alcohol & 0.142 & 0.000 & 0.147 & 0.000 \\
\hline Number of days of physical activity & 0.021 & 0.007 & 0.030 & 0.000 \\
\hline
\end{tabular}

Table 7.

Results.

high, but there is some positive correlation between people who frequently drink alcohol and those who smoke; there is also a negative correlation between people who smoke and those who eat frequently fruit and salad.

\subsection{Estimation results}

The estimation results of the ordered probits for self-assessed health and life satisfaction are presented in Table 7. The ordered probit for self-assessed health shows that demographic variables are not significant but, as expected, higher education and higher income are correlated with higher health status. The existence of chronic diseases, suffering physical limitations and feeling depressed, does not contribute to good health. Interestingly, we found that smoking and drinking are associated 
Lifestyles, Health, and Life Satisfaction among the Portuguese Seniors DOI: http://dx.doi.org/10.5772/intechopen.93250

\begin{tabular}{|c|c|c|c|c|c|}
\hline \multicolumn{3}{|c|}{ Self-assessed health } & \multicolumn{3}{|c|}{ Life satisfaction } \\
\hline \multicolumn{3}{|c|}{ Drinking alcohol } & \multicolumn{3}{|c|}{ Drinking alcohol } \\
\hline Predict & $\mathrm{dy} / \mathrm{dx}$ & $\mathbf{P}>\mathbf{z}$ & Predict & $\mathrm{dy} / \mathrm{dx}$ & $\mathbf{P}>\mathbf{z}$ \\
\hline 1 & -0.016 & 0.000 & 1 & -0.009 & 0.000 \\
\hline 2 & -0.019 & 0.000 & 2 & -0.019 & 0.000 \\
\hline 3 & 0.011 & 0.000 & 3 & -0.009 & 0.000 \\
\hline 4 & 0.019 & 0.000 & 4 & -0.007 & 0.000 \\
\hline \multirow[t]{2}{*}{5} & 0.005 & 0.000 & 5 & -0.006 & 0.000 \\
\hline & & & 6 & 0.034 & 0.000 \\
\hline \multicolumn{3}{|l|}{ Smoking } & 7 & 0.017 & 0.000 \\
\hline Predict 1 & -0.027 & 0.001 & & & \\
\hline 2 & -0.033 & 0.001 & \multicolumn{3}{|c|}{ Unhealthy food } \\
\hline 3 & 0.018 & 0.001 & Predict 1 & -0.007 & 0.000 \\
\hline 4 & 0.033 & 0.001 & 2 & -0.014 & 0.000 \\
\hline \multirow[t]{3}{*}{5} & 0.009 & 0.001 & 3 & -0.006 & 0.000 \\
\hline & & & 4 & -0.005 & 0.000 \\
\hline & & & 5 & -0.004 & 0.000 \\
\hline \multicolumn{3}{|c|}{ Number of days of physical activity } & 6 & 0.024 & 0.000 \\
\hline Predict 1 & -0.002 & 0.008 & 7 & 0.012 & 0.000 \\
\hline 2 & -0.003 & 0.007 & & & \\
\hline 3 & 0.002 & 0.008 & & & \\
\hline 4 & 0.003 & 0.007 & \multicolumn{3}{|c|}{ Number of days of physical activity } \\
\hline \multirow[t]{7}{*}{5} & 0.001 & 0.008 & Predict 1 & -0.002 & 0.000 \\
\hline & & & 2 & -0.004 & 0.000 \\
\hline & & & 3 & -0.002 & 0.000 \\
\hline & & & 4 & -0.001 & 0.000 \\
\hline & & & 5 & -0.001 & 0.000 \\
\hline & & & 6 & 0.007 & 0.000 \\
\hline & & & 7 & 0.003 & 0.000 \\
\hline
\end{tabular}

Table 8.

Marginal effects for lifestyle variables.

with the people's higher odds of reporting good health; but we also found that good health is reported when people exercise, as expected.

Concerning the ordered probit for life satisfaction, results are slightly different. Older people, and females particularly, tend to report higher levels of life satisfaction. Higher income is correlated with higher life satisfaction; no matter whether people are married or single, they tend to report identical satisfaction; however, having more than one person in the household increases the likelihood of reporting life satisfaction. Concerning the health variables, the results coincide with those found for selfassessed health. Any condition that risks the healthy feeling of people decreases life satisfaction except the BMI. Overweight is not correlated with lower but with higher life satisfaction. Finally, concerning lifestyle variables, we found that eating unhealthy food, drinking alcohol, and exercising are positively correlated with life satisfaction. 
Table 8 presents marginal effects for the significant lifestyle variables. It can be observed that for low levels of health, the change from "no frequent alcohol drinking" to "frequent drinking" and from "no frequent smoking" to "frequent smoking" decreases the perceived health status. Identically, for levels of life satisfaction below level 6, the change from "no frequent alcohol drinking" to "frequent alcohol drinking" and from "no unhealthy food" to "eating unhealthy food" decreases life satisfaction. Being physically active increases the "good health status" and also boosts the life satisfaction to higher levels (meaning levels 6 and 7). The gray shadowed values are statistically significant for a p-value smaller than 0.05 .

\section{Discussion}

Portugal is already a country of older people in Europe, and, as overall longevity increases, the number of people over the age of 65 will increase. Understanding the determinants of self-assessed health and life satisfaction and also understanding the role of lifestyle choices as determinants provide the basis for specific policy measures aimed at improving the overall well-being of senior citizens. The aim of this chapter was to estimate the set of main determinants and check the relevance of lifestyle variables as determinants of self-assessed health and life satisfaction of Portuguese people who are older than 65 years. We used data collected by the National Health Survey of 2014 and estimated two ordered probits.

The main results show that not all lifestyle variables are significantly explaining self-assessed health and life satisfaction. Surprisingly, we found that people who smoke and drink alcohol frequently reported a good health status; a good health status was also reported by those who frequently exercised. We also found that people reporting to eat unhealthy food and drink alcohol frequently tended to report higher life satisfaction as those reporting frequent physical exercise.

These results were unexpected. It may be argued that the participants only included people older than 65 years. At this age, people may feel that there is no need to change their behavior concerning smoking and drinking. They may think that the life time left should be comfortable and not restrictive. In fact, the share of people reporting smoking and drinking is relatively small, and their present health condition seems to let them satisfy their wishes or habits in relation to smoking and drinking.

The marginal effects confirm this to some extent. When people report low levels of health, when moving from "no smoking" to "smoking" or from "no drinking alcohol" to "drinking alcohol," a decreasing health status is reported. But for good levels of health, this tendency does not happen. It looks as if the good health status works as a protective status allowing people to make less healthy choices.

The determinants of the health status of older Portuguese follow previous studies, as was expected; good education and higher income contribute to a better health outcome. Interestingly, the opposite happens with married people, they are more likely to report bad or very bad health. It may be married people assess their own health in comparison with their partner or assess it as a joint indicator of the couple. This result must be carefully interpreted because married people also tend to report more often satisfied life satisfaction.

Determinants of life satisfaction follow the findings by Delhey [27]. Good health, family or close people, and decent income contribute to life satisfaction. Being a female and getting older also contributes to life satisfaction. Bad health conditions, affecting people physically or emotionally, decrease the health status and life satisfaction of people. 
People older than 65 years belong to the generation of baby boomers, and the oldest belong to the silent generation. The silent generation was born between 1928 and 1945, and the baby boomers were born between 1946 and 1964. Portugal was under an authoritarian corporatist government for 41 years, from 1933 to 1974. This means that people from these generations were born, raised, and worked under this political regime. Their values and attitudes were strongly shaped by their life experience. They have accomplished very low levels of education, and their retirement pensions are very low. This seems to have influenced the way people assess their health and life satisfaction, as well as their expectations and ambitions for life and health.

It is clear that many older Portuguese would improve their health and life satisfaction, had they received better education, and were entitled to larger retirement pensions. The very low level of income, often at level or below level of risk of poverty, requires particular attention from the authorities to prevent old age poverty and catastrophic health expenditures in future.

In general, older people are not smokers or heavy smokers, nor are they heavy drinkers. These characteristics, which are based on their socioeconomic condition, contribute to their health status and life satisfaction. However, some of their lifestyle choices will have negative health consequences. Those who tend to smoke are also more likely to drink alcohol, and this combination may potentiate future diseases and faster degradation of the health condition.

The large share of older people living in rural areas has the opportunity to grow their own vegetables and harvest fruits. For this reason, they are very likely to have a healthy diet and consume frequently vegetables, salads, and fruits. These people are very unlikely to engage in formal physical activity, but they are physically active in their life when growing vegetables and taking care of farm animals, all of which contributes to their well-being.

Future research on these topics needs to focus on the analysis of the unhealthy choices and their impact on health and life satisfaction. The results found here are changing in the near future because a new scenario is emerging. It may be worth analyzing the changes occurring as the baby boomers' generation dies and generation $\mathrm{X}$ enters old age.

\title{
Author details
}

\author{
Aida Isabel Tavares ${ }^{1,2}$ \\ 1 ISEG-UL, Lisbon School of Economics and Management, University of Lisbon, \\ Portugal \\ 2 CEISUC, Centre for Health Studies and Research, University of Coimbra, Portugal \\ *Address all correspondence to: aitavar@gmail.com
}

\section{IntechOpen}

(C) 2020 The Author(s). Licensee IntechOpen. This chapter is distributed under the terms of the Creative Commons Attribution License (http://creativecommons.org/licenses/ by/3.0), which permits unrestricted use, distribution, and reproduction in any medium, provided the original work is properly cited. (cc) BY 


\section{References}

[1] Eurostat. Statistics explained.

Population structure and ageing. 2019. Available from: https://ec.europa.eu/ eurostat/statistics-explained/index. php/Population_structure_and_ageing. [Accessed: 20 May 2020]

[2] Eurostat Database. 2020. Available from: https://ec.europa.eu/eurostat/ data/database [Accessed: 19 May 2020]

[3] OECD. Better life index. 2020. Available from: http://www. oecdbetterlifeindex.org/countries/ portugal/ [Accessed: 18 May 2020]

[4] Eurobarometer. Public Opinion. European Commission. 2020.

Available from: https://ec.europa. eu/commfrontoffice/publicopinion/ index.cfm/Chart/getChart/themeKy/1/ groupKy/1 and https://ec.europa.eu/ commfrontoffice/publicopinion/index. cfm/General/index [Accessed:

20 May 2020]

[5] Gesis. 2020. Available from: https:// www.gesis.org/eurobarometer-dataservice/search-data-access/eb-trendstrend-files/list-of-trends/life-satisf. [Accessed: 18 May 2020]

[6] ESS. 2020. Available from: https:// www.europeansocialsurvey.org/ [Accessed: 18 May 2020]

[7] Eurostat. 2020. Statistics explained. Overall life satisfaction in the EU explained. Online data code: il_pw01. Available from: https://ec.europa.eu/ eurostat/statistics-explained/index. php?title=Subjective_well-being_-_ statistics\#Overall_life_satisfaction_in_ the_EU [Accessed: 19 May 2020]

[8] Vala JT, Ramos A, Lavado S. European Social Survey-Comparative Global Results. Lisboa: Instituto de Ciencias Sociais; 2010 (in Portuguese)

[9] SHARE. SHARE—Survey of Health, Aging, and Retirement in Europe. 2020.
Available from: http://www.shareproject.org/home0.html [Accessed: 20 May 2020]

[10] Diener E, Seligman M. Beyond money. Psychological Science in the Public Interest. 2004;5(1):1-31

[11] Sabatini F. The relationship between happiness and health: Evidence from Italy. Social Science \& Medicine. 2014;114:178-187

[12] Okun MA, Stock WA, Haring MJ, Witter RA. Health and subjective well-being: A meta-analysis. The International Journal of Aging and Human Development. 1984;19(2):111-132

[13] Steptoe A, Deaton A, Stone AA. Subjective wellbeing, health, and ageing. Lancet. 2014. DOI: 10.1016/ S0140-6736(13)61489-0. Published online $6 \mathrm{Nov}$

[14] Anand P. Happiness, well-being and human development: The case for subjective measures. In: Human Development Report. Background Paper. 2016

[15] Dolan P, Peasgood T, White M. Do we really know what makes us happy? A review of the economic literature on the factors associated with subjective wellbeing. Journal of Economic Psychology. 2008;29:94-122

[16] Frey B, Stutzer A. Happiness, economy and institutions. The Economic Journal. 2000;110:918-938

[17] Dahlgren G, Withitehead M. Polices and Strategies to Promote Social Equity in Health. Stockholm: Institute for Future Studies; 1991

[18] Blaxter M. Health and Lifestyles. London: Routledge; 1990 
[19] Kye SY, Park K. Health-related determinants of happiness in Korean adults. International Journal of Public Health. 2014;59:731-738

[20] Gschwandtner A, Jewell SL, Kambhampati US. On the relationship between lifestyle and happiness in the UK. In: School of Economics Discussion Papers, No. 1613. Canterbury: University of Kent, School of Economics; 2016

[21] WHO. Diet, nutrition, and the prevention of chronic diseases. In: Joint WHO/FAO Expert Consultation. WHO Technical Report Series No. 16. Geneva: WHO Press; 2003

[22] WHO. Global Health Risks Mortality and Burden of Disease Attributable to Selected Major Risks. 2009. Available from: http://www.who. int/healthinfo/global_burden_disease/ GlobalHealthRisks_report_full.pdf [Accessed: 20 May 2020]

[23] WHO. World Report on Aging and Health. Geneve: WHO Press; 2015

[24] Rodrigues V, Mota-Pinto A, Sousa B, Botelho A, Alves C, Oliveira CR. The aging profile of Portuguese population: A principal component analysis. Journal of Community Health. 2014;39(4):747-752

[25] Silva PA. Individual and social determinants of self-rated health and well-being in the elderly population of Portugal. Cadernos Saúde Pública. 2014;30(11):2387-2400

[26] Paul C, Teixeira L, Ribeiro O. What about happiness in later life? In: Phellas C, editor. Aging in European Societies, Healthy Aging in Europe. New York: Springer; 2013. pp. 83-96

[27] Delhey J. Life Satisfaction in an Enlarged Europe. Luxembourg: European Foundation for the Improvement of Living and Working Conditions, Office for Official
Publications of the European

Communities; 2004

[28] Santos DM, Rodrigues S, De Oliveira B, Vaz-De-Almeida MD. Diet quality in elderly Portuguese households. Journal of Nutrition, Health \& Aging. 2013;18(3):243-250

[29] Bosque-Prous M, Brugal MT, Lima KC, Villalbí JR, Bartroli M, Espelt A. Hazardous drinking in people aged 50 years or older: A crosssectional picture of Europe, 2011-2013. International Journal of Geriatric Psychiatry. 2016;32(8):817-828

[30] Carreira H, Pereira M, Azevedo A, Lunet N. Trends in the prevalence of smoking in Portugal: A systematic review. BMC Public Health. 2012;12(1):958

[31] Padrão P, Lunet N, Santos AC, Barros H. Smoking, alcohol, and dietary choices: Evidence from the Portuguese National Health Survey. BMC Public Health. 2007;7(1):138

[32] Haveman-Nies A, de Groot LC, van Staveren WA. Relation of dietary quality, physical activity, and smoking habits to 10 -year changes in health status in older Europeans in the SENECA study. American Journal of Public Health. 2003;93(2):318-323

[33] Gomes M, Figueiredo D, Teixeira L, Poveda V, Paúl C, Santos-Silva A, et al. Physical inactivity among older adults across Europe based on the SHARE database. Age and Ageing. 2017;46(1):71-77

[34] Instituto Nacional de Estatística. Inquérito Nacional de Saúde: 2014. Lisboa: INE; 2016. Available from: www. ine.pt/xurl/pub/263714091>. ISSN 1646-4052. ISBN 978-989-25-0356-1 



\title{
Retired but Not Tired: Entrepreneurial Motives and Performance among Retired Public Servants in Tanzania
}

\author{
Anselm Namala and Mursali A. Milanzi
}

\begin{abstract}
Venturing into a business venture at an old age is an interesting phenomenon. Retirees seem to consider this decision as imperative as it provides them with a source of earning and keeps them active post-retirement. Despite a plethora of research on entrepreneurship, there is a paucity of research on entrepreneurial behavior and performance retired public servants. The current study examines the motive and performance of businesses owned by retired public servants in Tanzania, one of the developing economies. The study used a survey of 90 randomly selected public servants who retired between 2012 and 2016. The descriptive and probit regression analyses were used to examine the entrepreneurial performance and factors associated with it. The results of the analysis suggest that the performance of the businesses is generally not good, as the majority made losses for the past 3 years consecutively. As for the determinants of performance, the study observed that age and source of capital negatively affect performance, whereas education and planning/preparations for business establishment positively influenced entrepreneurial performance. The findings imply that employees, employers and social security industry have a role to play in creating awareness and preparing public service employees for life after retirement especially in sustaining postretirement income. Lumpsum pension and monthly allowance may be necessary, but the knowledge to manage them through profitable business ventures my be sufficient for a better post-retirement life.
\end{abstract}

Keywords: retirement, business performance, public service retirees, post-retirement income

\section{Introduction}

Public servants have a variety of economic activities to venture into after retirement. Self-employment in businesses and agricultures are among the activities retired employees tend to venture into. According to [1] self-employment in business entities accounts for $26.1 \%$ of the retiree sources of income, a second highest source behind farming activities which contribute $38.5 \%$. The number of retirees venturing into business has been growing in the recent past. For example, RBA [1] established that about $21 \%$ of retired public servants use their lumpsum payments 
to start business ventures. This suggests that there is an increased desire among retirees to venture into business even using their long and hard-earned incomes.

One wonders why the retired public servants would venture into business at an old age. Of course, one can retire from formal employment, but never get tired to explore alternative means of survival at the post-retirement age. Entrepreneurship theories are replete with explanations of the motives for starting or running a business venture. Generally, the entrepreneurship literature highlights financial and non-financial motives for becoming an entrepreneur. Among the financial motives is seeking income growth through profit maximization and profit satisficing. As for non-financial motives, the literature identifies a need to remain independent as one of the key motives of entrepreneurship. The motives differ across geographical and institutional contexts. For example, Isaga et al. [2] found that pull factors are more important for starting a business in developing countries than push factors. Other studies have shown that the motives vary by gender and country $[3,4]$. In most cases, this literature assumes that most successful entrepreneurs begin their entrepreneurial journey at a young age, while they are still energetic. This seems to suggest as well that motives to becoming an entrepreneur may differ by age. As such, the entrepreneurial motives might be different for the retired civil servants given that the entrepreneurial endeavor begins at an old age. In Tanzania, the normal retirement age is 60 years. But, in some sectors such as higher education (professors) and judiciary (judges), the retirement ages are 65 and 70 years, respectively.

In the context of the retired public servants, Shiamwama [5] indicates that the entrepreneurial motives for establishing a business venture include seeking the means of income, aiming to become active hence, overcoming post-retirement boredom. Similarly, Kodia $[6,7]$ suggest that venturing into businesses provides an opportunity to earn income and sustain life after retirement. Some retirees do business as their hobbies. That is, after retirement it is an opportunity for someone to establish a business venture of interest and passion. For whatever reasons retirees choose to start and run the business entities, ensuring that the business performs well is certainly a primary concern.

Shiamwama [5] notes that $60 \%$ of the retirees established small scale businesses of diverse products, with service and retail businesses being the dominant ones. Nearly a quarter, $21.4 \%$, of the retirees depend on business activities as their main source of income [8]. The study also reveals that the majority of incomes for retirees come from commercial farming. Bukwimba [9] notes that in Tanzania about 51\% of the retirees depend on pension as their main source of income. The remaining retirees make their living through smallscale businesses.

Some public and private institutions such as Tanzania Global Learning Agency (TaGLA), National Institute for Productivity (NIP) and Association of Tanzania Employers (ATE) have been running training programs in business skills enhancement to preparing the public servants for retirement. It is assumed that offering pre-retirement training would adequately prepare them to support themselves and their families after retirement. Amid a growing number of retirees venturing into business operations, a concern on the performance of their businesses arise. RBA [8] reveals that about $49 \%$ of the businesses owned by the retirees were not generating profit, while about $21 \%$ collapsed within the first three years of their establishment. This suggests that understanding the performance of these businesses is imperative. Refs. [5, 6] examined the performance of business run by retired civil servants. These studies have largely been descriptive hence, do not provide sufficient insights into the motive and performance of the businesses as well as their antecedents. This chapter examines the engagement of retirees in businesses and performance in Dar es Salaam, Tanzania. 
The rest of the chapter is structured as follows. Section 2 provides an overview of the underlying theory and literature informing the study. This is followed by a description of the methodology of the study in Section 3. Section four presents the results of the analysis and discussions of findings. In section five, the chapter concludes and highlights the main policy and practical implications.

\section{Theoretical framework}

This study is based on the resource-based perspective of the firm. The resourcebased perspective has its root in [10] who views a firm as a bundle of resources i.e. assets that reside within its boundary. Refs. [11,12] further developed the resource-based perspective of the firm and later [13] popularized it, advancing the idea that business performance hinges on resources owned and strategies pursued. The resources can be found in the form of physical and human assets, trade secrets, engineering experience organization routines and organization's specialized assets are the key drivers of firms' performance $[13,14]$. As such, the ability of the firms to exploit and develop these resources and capabilities to determine business success.

Resource-based perspective is founded in the tenet that firms within an industry are heterogeneous in terms of resource ownership and that the resources are imperfectly mobile across firms. Firm heterogeneity determines differential levels of effectiveness and efficiency in the production of goods and services. As long as such resources are imperfectly mobile, firms which own them can earn superior rent $[13,15,16]$. According to [13], there are two broad categories of resources; those determining competitive advantage and those sustain sustaining it. Sustainable competitive advantage, also superior performance, is achieved by exploiting and leveraging on the resources that are valuable, rare, imperfectly imitable and non-substitutable.

Kodia [6] describes the nature of resources that a firm possesses such as tangible assets, intangible assets and external assets. Tangible assets comprise of physical resources whereas intangible assets are those that cannot be seen and quantified, that include but are not limited to business knowledge experience, technical skills, reputational resources like trademarks, patents, brand and goodwill as well as networks, individual and group skills, interactions and the organizational routines and processes used to organize and coordinate these resources. External resources are acquired through interrelationship with other actors within the environment such as suppliers and customers, competitors and business support institutions. Possessing or not possessing and utilizing resources can affect the performance of businesses owned by public service retirees.

The resource-based perspective offers valuable insights into the understanding of business performance among retired public servants. Retired public servants need resources to establish and/or run business to provide a sustainable income after retirement. The kinds of resources that matter for entrepreneurial performance is perhaps the most difficult question to address. Nonetheless, according to [17] a resource of any form, be it financial, human or a building is a prerequisite for the successful performance of an organization. Similarly, $[6,18]$ add that both external (business location, customer satisfaction, competition and government regulations) and internal (mental and physical stamina, organization structure, financial stability, experience in the market) business environment being important factors affecting the performance of business firms. Based on the foregoing, the resource-based perspective can be applied to evaluate firms' resource positions, and answer such questions as to why some businesses owned by the retired public servants make a profit while others make a loss? Why does 
the level of profit of some businesses owned by the retired public servants vary despite being in the same industry?

\section{Research methodology and analytical framework}

The study is based on a cross-section survey of public servants who retired between 2012 and 2016 and engaged in various entrepreneurial activities in Dar es Salaam region. Information about the businesses and retirees was collected from Tanzania Global Learning Agency (TaGLA), the executive agency of the government agency responsible for capacity building of middle and senior government officials. The study used a sampling frame of 898 retired public servants, which was based on a list of participants of retirement planning workshops organized by TaGLA.

Based on the sampling frame, the study randomly selected 90 retired public servants who owned small and medium businesses. The study applied the formula proposed by [19], which is presented as:

$$
\mathrm{n}=\frac{N}{1+\mathrm{N}(e)^{2}}
$$

where, $\mathrm{n}=$ Sample size

$\mathrm{N}=$ Total number of small and medium entrepreneurs

$\mathrm{e}=$ Error (level of significance) $=10 \%$

$\mathrm{n}=898 / 1+898(1)^{2}$

$\mathrm{n}=898 / 1+898(0.1)^{2}$

$\mathrm{n}=898 / 9.98$

$\mathrm{n}=90$

A sample size of 90 public servants is about $10 \%$ of the population. Hill [20] suggests that at least $10 \%$ of the population is satisfactory for scientific research. The study administered a survey questionnaire to owners of small and medium enterprises. The questionnaire was both structured and semi-structured, and the study used a researcher-administered questionnaire approach. This approach gave an avenue for both researchers and respondents to clarify some aspects of the questions and/or answers for a better understanding of the phenomenon. Consequently, the approach produces not only quality responses but also high response rate [21].

Before the survey, the study subjected the questionnaire to some rounds of reviews by experts and peers. Thereafter, the study pre-tested the questionnaire by purposively selected respondents, who were not part of the study. These processes ensured the quality and enhanced the face and content validities [22, 23].

In total 90 questionnaires were collected. Of these, 86 questionnaires were deemed usable for the intended goal of the study, giving an effective response rate of $96 \%$. Therefore, the findings of the study are based on the analysis of responses from 86 respondents.

\subsection{Variables and measurements}

Table 1 shows a list of variables of the study and their respective measurements. The dependent variable of the study is business performance. Entrepreneurial performance can be construed as the ability of a business to reach certain goals throughout the entire entrepreneurial process [24]. Literature provides numerous 
Retired but Not Tired: Entrepreneurial Motives and Performance among Retired Public Servants... DOI: http://dx.doi.org/10.5772/intechopen.94281

\begin{tabular}{|c|c|c|}
\hline Variable name & Definition & Operationalization \\
\hline \multicolumn{3}{|l|}{$\begin{array}{l}\text { Dependent } \\
\text { Variable }\end{array}$} \\
\hline $\begin{array}{l}\text { Business } \\
\text { performance }\end{array}$ & $\begin{array}{l}\text { Whether or not the business made a profit in the } \\
\text { past } 3 \text { years }\end{array}$ & $\begin{array}{l}1=\text { if made a profit; } 0=\text { if made } \\
\text { a loss }\end{array}$ \\
\hline \multicolumn{3}{|l|}{$\begin{array}{l}\text { Explanatory } \\
\text { Variables }\end{array}$} \\
\hline Sex & Sex of owner of the business & $1=$ male $; 0$ = female \\
\hline Education & Level of education of owner of the business & $\begin{array}{l}1=\text { at least a first-degree level; } \\
0=\text { otherwise }\end{array}$ \\
\hline Age & $\begin{array}{l}\text { Age of owners at the time of starting the } \\
\text { operation of the business }\end{array}$ & Ratio scaled \\
\hline Family size & Number of people living in the retiree household & $\begin{array}{l}\text { A count of people living in the } \\
\text { retiree household }\end{array}$ \\
\hline Motive & Motivation to start a business & $\begin{array}{l}1=\text { Availability of capital } \\
0=\text { otherwise }\end{array}$ \\
\hline Industry & Sector of operation & $\begin{array}{l}1=\text { agriculture and related } \\
\text { products; } 0=\text { other sectors }\end{array}$ \\
\hline Capital & $\begin{array}{l}\text { The variable concerns the source of capital for } \\
\text { business start-up i.e. where the capital to start } \\
\text { the business was obtained. }\end{array}$ & $\begin{array}{l}1 \text { = Pension (lumpsum } \\
\text { payment); } 0 \text { = other sources }\end{array}$ \\
\hline Planning & $\begin{array}{l}\text { If there was any preparation e.g. planning to } \\
\text { start a business before retirement }\end{array}$ & $\begin{array}{l}1=\text { Planned before retirement; } \\
0=\text { otherwise }\end{array}$ \\
\hline
\end{tabular}

Table 1.

Variables and measurements.

approaches for measuring business performance, some use objective measures such as sales revenue or profit, others use subjective measures such as satisfaction with the achieved targets. The current study measured business performance using a profitability indicator. Given the nature of the business surveyed were small and medium-sized, it was difficult to measure profitability objectively due to unavailability of official or audited profitability records. A lack of official financial performance data is common among small and medium-sized firms especially in a developing context such as Tanzania. As such, the study relied on a self-reporting qualitative measure of profitability. In this, the study solicited information on whether or not the business recorded any profit or loss consecutively for the past three years. The study constructed a dummy variable, coded 1 for businesses that reported some profit and 0 for those reported some losses.

Sex: This is one of the explanatory variables, which is conceptualized to influence business performance. Aprile and Fiorillo [25] suggests that women culturally spend more time on domestic-related activities compared to men, which disadvantages them in business. The study expected that businesses owned by male retirees would perform better than those owned by female retirees. The variable sex is categorical hence, coded 1 for businesses owned by male retired public servants and 0 otherwise.

Education: education is associated with knowledge and the ability to interpret business-related information. Retired public servants with a higher level of education are likely to perform better as they can possess information on market and manage resources efficiently [26]. As such, the study conceives education to be positively associated with business performance. The variable education is categorical, coded 1 for owner holding at least a first degree, and 0 otherwise. 
Age is a simple count of the number of years at business start-up. The variable age is a proxy for experiential knowledge accumulated over time for business problem-solving. Theoretically, older people are expected to perform better than young ones since they have more knowledge. Similarly, older individuals may have established reputation and trust among its stakeholders hence, can face limited uncertainties in its business environment. However, [5, 6] seem to suggest that younger individuals may be more flexible and creative and hence, can outperform the older ones. As such, the direction of the relationship is inconclusive, i.e. can be either way.

Family size: family size is measured as a number of all members living in the family. Family size may have dual effects. First, a large family could be a source of the cheap labour force as more family labour can be employed in the business, leading to higher performance. Second, large family size increases the costs (dependency ratio) especially when the consumer-worker ratio is high. In line with $[5,6]$, businesses run by large families are less likely to record higher performance.

Motive: the study intended to understand what impelled the retired public servants to start a business. Entrepreneurship literature is replete with explanations regarding the motives for starting a business venture. For example, some start a business due to the pull factors such as becoming independent, wealth, and self-fulfillment, whereas others are motivated by the external or push factors such as insufficient salaries, unemployment and job dissatisfaction [27]. The pull factor also includes the availability of resources such as capital. For retired public servants, capital availability has been an important motivation for starting a business venture [5]. Nonetheless, the fact that retired public servants lack alternative employment, entrepreneurship could be a necessity [28]. The study used a categorical variable coded 1 if capital availability was a motive to start a business, and 0 otherwise.

Sector: the performance of business vary by sector. Each sector has specific characteristics such as capital requirement, norms and governance mechanisms along the value chains. Businesses with small start-up capital, easy to manage and with a reliable market, such as livestock husbandry, are less vulnerable as compared to other businesses [6]. In this study, the variable sector was coded 1 for the agricultural sector, and 0 for other sectors.

Capital: the variable capital concerns the sources of money used to establish the business. There are a multitude of sources of capital including own saving, and loan/credit from financial or non-financial institutions. For retired individuals, a lumpsum pension is an important source of capital to start or expand the business. This study examines the influence of the source of capital on business performance. As such, a dummy variable is introduced, which is coded 1 if the pension lump sum was used for starting the business, and 0 if the owner used other sources of capital.

Planning: the study sought to understand the role of pre-retirement planning on the performance of the business owned by retired public servants. For a business to survive and grow in a competitive environment, it certainly requires adequate preparations and planning before taking-off. In this vein, the study solicited information on whether or not the retired public servants started the preparations before the retirement or post-retirement such as attending entrepreneurship training and participating in retirement preparation seminars. Kodia [6] suggests that public servants who start preparations before retirement do better in business than their counterparts. This is because they get an opportunity to learn about the nature of the business, markets, competitors and the supporting environment. The variable planning was categorical, coded 1 if planning started ahead of retirement and, 0 if started after retirement. 


\subsection{Analytical framework}

In section 3.1, the study describes the measurement of the variables under the analysis. The dependent variable, business performance, was conceptualized as a dummy variable, which takes the value of 0 for businesses that made a loss and 1 for those made profit in the specified period. To analyze a regression model with a binary response-dependent variable, the linear probability model (LPM), logit model and probit model are often used [29]. The LPM is not suitable because it can predict the probability value of an outcome variable below zero (0) or above one (1). This does not make sense since probability values are bounded between 0 and 1 . The logit and probit models often produce the same result, but differ in the assumption underlying the error term. The error term in the logit model follows the cumulative standard logistic distribution (i.e. exponential distribution), whereas for the probit the error term is assumed to follow the cumulative standard normal distribution.

In this study, the probit model is applied. The model is suitable for a relatively small sample size i.e. from 40 up to 150 observations [30]. The general probit model can be formulated as:

$$
Y_{i}^{*}=X_{i}^{\prime} \beta+\mu_{i}
$$

where $\mathrm{Y}^{*}=$ is the business performance variable, $\mathrm{X}$ is a vector of explanatory variables, $\beta$ is a vector of coefficients measuring the magnitude and direction of the relationships, and $\mu$ is a normally distributed error term. $Y^{*}$ is a latent (unobserved) variable, it can only be observed when the business makes a profit, not otherwise. The observed variable is Y. Hence, the relationship between the observed and latent variable can be expressed as:

$$
y=\left\{\begin{array}{l}
1 \text { if } y *>0 \\
0 \text { if } y *<0
\end{array}\right.
$$

Based on Eq. (2), [31] suggest that there is an underlying propensity to make a profit that generates the observed state $Y$. The propensity to make the profit is unobservable, but a change in $\mathrm{Y}^{*}$ results in an observed $\mathrm{Y}$. For a given value of $\mathrm{X}$, it is true that:

$$
\operatorname{Pr}(y=1 / X)=\operatorname{Pr}\left(y^{*}>0 / X\right)
$$

Substituting and rearranging in (3) above, we obtain:

$$
\operatorname{Pr}(y=1 / X)=\operatorname{Pr}[\varepsilon>-(X \beta]
$$

Given that the distribution of $\varepsilon$ is normal, the binary probit regression can be written as:

$$
\operatorname{Pr}(y=1 / X)=\int_{-\infty}^{x \beta} \frac{1}{\sqrt{ } 2 \pi} \exp \left(\frac{t^{2}}{-2}\right) \delta t
$$

Eq. (5) suggests that the probability of making a profit is defined by the cumulative normal density function (CDF) of $\varepsilon$ at a given level of $\mathrm{X}$, which can simply be presented as: 


$$
\operatorname{Pr}(y=1 / X)=\Lambda(X \beta)
$$

For easy and meaningful interpretation of the probit model coefficients, the study transformed the normal coefficients into the marginal effect coefficients. With the marginal effect coefficients, the interpretation is done in terms of a change in the probability for a given marginal change in the explanatory variables.

\section{Results of analysis and discussions of findings}

This section presents the results of the analysis. The section is divided into two main sub-sections. The first subsection presents the results of the descriptive statistical analysis which mostly highlights the profile of businesses and respondents surveyed. The second subsection is for the results of the multivariate analysis of the model proposed in the previous section (Table 2).

\subsection{Size and sector of businesses}

The study examined the size of the businesses surveyed. The measure of the size of the businesses was in terms of the number of full-time employees and sales turnover, which aligns with Tanzania's SMEs development policy [32]. Table 3 shows the results of the analysis. Forty-seven, 47 (55\%) of the surveyed businesses had employed less than 5 people at the time of establishment. In this vein, the majority of businesses are Micro and Small Enterprises (MSE) in nature.

During the survey in 2017, about $80 \%$ of firms had employed the same number of people. The results suggest that the majority of businesses did not grow as evidenced by the dwindling number of employees in the upper categories. For example, businesses which employed between 5 to 10 people at the establishment, experienced a drop in the number of employees from $29 \%$ to about $19 \%$ in 2017.

\begin{tabular}{lcccc}
\hline \multirow{2}{*}{ Employees } & \multicolumn{2}{c}{ At the start of business } & \multicolumn{2}{c}{ By 2017 } \\
\cline { 2 - 5 } & Frequency & \% & Frequency & \% \\
\hline 4 or less & 47 & 54.7 & 69 & 80.2 \\
\hline $5-10$ & 25 & 29.1 & 16 & 18.6 \\
\hline 10 or more & 14 & 16.3 & 1 & 1.2 \\
\hline Total & $\mathbf{8 6}$ & $\mathbf{1 0 0 . 0}$ & $\mathbf{8 6}$ & $\mathbf{1 0 0 . 0}$ \\
\hline
\end{tabular}

Table 2.

Number of employees.

\begin{tabular}{cccc}
\hline Year & Profit & Loss & Total \\
\hline 2015 & $28(33 \%)$ & $58(67 \%)$ & 86 \\
\hline 2016 & $36(42 \%)$ & $50(58 \%)$ & 86 \\
\hline 2017 & $44(51 \%)$ & $42(49 \%)$ & 86 \\
\hline
\end{tabular}

Table 3.

Business profitability. 
Firms with 10 or more employees also dropped from $16 \%$ at the start to only $1 \%$ in 2017. This also indicates that businesses owned by retirees initially engaged a large number of employees. As time went by, the number of employees decreased. This could be a result of a poor performance that led to the inability to compensate the employees.

\subsection{Business sales turnover and profitability}

The purpose of establishing any business is to achieve some goals such as raising income through profit. A good performing business generates more revenue and records profit. The study examined these two aspects to determine how the businesses owned by retired public servants are faring in the market. The results of the analysis suggest that about $40 \%$ of firms generated revenues averaging between Tanzanians shillings 20 and 21 million from 2015 to 2017. There was an increase in the number of businesses in this category between 2015 and 2017, suggesting that on average the annual sales turnover decreased from the higher categories. For example, businesses with sales turn-over of Tshs. 22,000,000 or above declined from $44.2 \%$ in 2015 and 2016 to only $23.3 \%$ in 2017. Apparently, most of the businesses owned by the retirees in Dar es Salaam are micro and small enterprises (MSEs) [32]. This result collaborates the analysis of firm size based on the number of full-time employees in an earlier section.

As regard business profit, the study determined whether or not the business consecutively recorded any profit between 2015 and 2017. Table 3 shows that in 2015 and 2016, the majority of businesses did not make any profit. In 2017, about $51 \%$ made a profit. This is in line with previous studies conducted in Kenya which showed that nearly half of businesses owned by retirees were not creating a profit. Other businesses collapsed within the first three years of their establishment [8]. Similarly, [5, 6] revealed that businesses owned by retirees in their samples did not perform well.

\subsection{Sources of capital}

Businesses can be established using different sources of capital. The study inquired about the sources of capital for businesses owned by the retired public servants in Dar es Salaam, Tanzania. The study observed that about $54 \%$ of the businesses were established using a pension lump sum. This suggests that the majority of businesses were financed through lumpsum pension received after retirement. Savings was the second option accounting for $22 \%$, followed by loans from financial and non-financial institutions (19\%). Few (6\%) relied on family contribution to start-up capital. On the whole, the findings suggest that most retired public servant entrepreneurs did not establish businesses before their retirement due to lack of capital.

\subsection{Entrepreneurial motivation}

An important aspect of entrepreneurship studies is an understanding of entrepreneurship motivation. This answers the question of the underlying reason for becoming an entrepreneur. Several motives have been described in the entrepreneurship. This study enquired from the retired public servants the motives for their engagement in the entrepreneurial activities. Table 4 shows the results of the analysis of the motives for entrepreneurial involvement. The majority of entrepreneurs (31\%) indicated that they established business due to capital availability. This is consistent with the results of the analysis of the sources of capital in an earlier 
section, which show that most businesses were established using a lumpsum pension (See Table 5). Other frequently mentioned motives included possession of business knowledge and experience (17\%), and market availability (12\%). All these motives can be grouped under the pull factors. As such, it seems logical to think that the majority of the retired public servant became entrepreneurs due to the pull factors, which is consistent with [5].

\subsection{Challenges facing retired public servant entrepreneurs}

Table 6 shows the challenges that the retired public servant entrepreneurs encounter. It is understood that in a competitive business, especially in developing countries, businesses often encounter a multitude of challenges. As the results suggest, the retirees' business start-ups face challenges such as lack of business knowledge and skills (36\%), lack income diversity, i.e. overreliance on business $(17 \%)$, and inadequate business experience (16\%). Other challenges are due to management problems, such as managing records (17\%) and supervision (13\%). Most of these challenges are rooted within the businesses and owners. [27, 33] seems to attest management and business knowledge or skills form the most important challenges to an entrepreneurial endeavor. In this vein, the challenges emanating from the external environment such as regulatory framework are not deemed salient among the retired public servant entrepreneurs. On the whole, businesses owned by the retired public servants are more vulnerable to these challenges affecting their growth.

\begin{tabular}{lcc}
\hline Motivation & Frequency & \% \\
\hline Learnt from colleagues & 5 & 5.8 \\
\hline Capital availability & 27 & 31.4 \\
\hline Market availability & 10 & 11.6 \\
\hline Business Knowledge \& experience & 15 & 17.4 \\
\hline Business Location & 3 & 3.5 \\
\hline Business passion & 6 & 7.0 \\
\hline Profitability (seeking income growth) & 6 & 7.0 \\
\hline Others & 14 & 16.3 \\
\hline Total & $\mathbf{8 6}$ & $\mathbf{1 0 0}$ \\
\hline
\end{tabular}

Table 4.

Entrepreneurial motivation.

\begin{tabular}{lcc}
\hline Source & Number & Percentage \\
\hline Bank loan & 8 & 9.3 \\
\hline Saccos loan & 8 & 9.3 \\
\hline Savings & 19 & 22.1 \\
\hline Lumpsum pension & 46 & 53.5 \\
\hline Family contribution & 5 & 5.8 \\
\hline Total & $\mathbf{8 6}$ & $\mathbf{1 0 0}$ \\
\hline
\end{tabular}

Table 5.

Sources of capital. 
Retired but Not Tired: Entrepreneurial Motives and Performance among Retired Public Servants... DOI: http://dx.doi.org/10.5772/intechopen.94281

\begin{tabular}{lcc}
\hline Nature of challenges & Frequency & $\%$ \\
\hline Lack of business experience & 14 & 16.3 \\
\hline Lack of business knowledge and skill & 31 & 36.0 \\
\hline Difficulties in managing business records & 5 & 5.8 \\
\hline Overdependence on income from business & 15 & 17.4 \\
\hline Lack of business supervision skills & 11 & 12.8 \\
\hline Others & 10 & 11.6 \\
\hline Total & $\mathbf{8 6}$ & $\mathbf{1 0 0}$ \\
\hline
\end{tabular}

Table 6.

Main challenges in managing business.

\subsection{Results of regression model}

Table 7 shows the results of the analysis of the factors influencing the performance of businesses owned by the retired public servants in Dar es Salaam, Tanzania. The probit regression model was employed to determine factors influencing the likelihood of a business making or maintaining a profit. The analysis suggests that four factors have a significant association with business performance as measure by business profitability. These include the age of starting a business, owner education level, source of capital and business preparation/planning. The study did not find significant relationships between business performance and variables such as sex, sector/industry, and entrepreneurial motive.

The findings suggest that the age of the retired public servants at the start of the business is negatively and significantly related to business performance. Its marginal effect coefficient is $-0.054(\mathrm{p}=0.026)$. This means that an additional year decreases the probability of recording profit by $5.4 \%$, all else being equal. In other words, a retired public servant who starts a business at an older age is less likely to record profit. Aged retirees are prone to mental and physical stamina (health) challenges which might affect their business performance. The finding of the negative relationship between age and performance is consistent with [1]. The study found that unlike young retirees, older ones do not perform well in business. Similarly, according to [34], age is associated with creativity and innovation, and it diminishes with age. The results, thus, support prior expectations.

The variable education level is positively related to business performance. Its marginal effect coefficient is 0.183 ( $\mathrm{p}=0.019)$. This suggests that higher education is associated with $18 \%$ increase in the probability of getting profit in the businesses owned by the retired public servant. Education level is linked to knowledge and ability to interpret market information as well as the ability to explore business opportunities. Shiamwama [5] noted that the level of education and the attendance of management training courses are important aspects in terms of small and micro business firm survival. Besides, [35] contend that education spurs intrinsic motivation and energizes entrepreneurial attitudes and behaviors. Education enhances the capacity to innovate, collaborate with other businesses and individuals to promote higher firm growth. As such, the business operated by a highly educated entrepreneur is more likely to succeed. The findings in the present study confirm the assumptions of the resource-based perspective of organizational performance, as education and knowledge are deemed critical internal resources for sustaining the competitiveness of the firm [13].

The variable source of capital is negatively associated with business performance, suggesting that retired public servants who financed their startups through 


\begin{tabular}{|c|c|c|c|c|}
\hline Variables & Coeff. & Std. errors & Marginal effect & P-value \\
\hline Age & $-0.523^{* *}$ & 0.234 & $-0.054^{* *}$ & 0.026 \\
\hline Family size & -0.240 & 0.256 & -0.025 & 0.346 \\
\hline Education & $1.752^{* *}$ & 0.747 & $0.183^{* *}$ & 0.019 \\
\hline Sex & -0.778 & 0.587 & -0.081 & 0.185 \\
\hline Industry/sector & -0.391 & 0.656 & $-0.252^{* * *}$ & 0.551 \\
\hline Source of capital & $-2.448^{* * *}$ & 0.846 & $-0.252^{* * *}$ & 0.004 \\
\hline Motive & -0.725 & 0.649 & -0.075 & 0.264 \\
\hline Planning & $2.756^{* * *}$ & 0.765 & $0.287^{* * *}$ & 0.000 \\
\hline Observations & 86 & & & \\
\hline LR chi2 (8) & 76.86 & & & \\
\hline Prob > chi2 & 0.000 & & & \\
\hline Pseudo $\mathrm{R}^{2}$ & 0.71 & & & \\
\hline \multicolumn{5}{|c|}{$\begin{array}{l}{ }_{\text {significant at } 10 \% \text { level }(p \text {-value }<0.1) .} . \\
\text { significant at } 5 \% \text { level }(p \text {-value }<0.05) . \\
\text { Significant at } 1 \% \text { level }(p \text {-value }<0.01) .\end{array}$} \\
\hline
\end{tabular}

Table 7 .

Factors influencing business performance.

pension lump sum were less likely to perform well. The marginal effect coefficient of this is -0.252 ( $p=0.004)$, suggesting that unlike those who financed the business through other sources, retired public servants who finance through pension lump sum have a $25 \%$ less chance of running a profitable business. According to [1], one-tenth of the businesses which use pension lump sum as sources of capital collapse within the three years of inception. This simply suggests that businesses established after retired and using lump sum pension tend to record losses and eventually collapse. [36] observes that the growth of the majority of SMEs are capital constrained, as heavily rely on the internal sources of business financing strategies. However, for retirees, the problem may not be a lack of access to finance, but rather the inability to manage huge pension lump sum based capital.

The result of the analysis of the variable planning business start-up shows that retired public servants who start their business planning before retirement are more likely to perform better than their counterpart. The marginal effect coefficient of this variable is positive (0.284) and statistically significant at the $1 \%$ level $(p=0.000)$. Hence, the probability of getting profit for business which began planning earlier is higher by $28 \%$ than for those who started planning after retirement. Planning for retirement involves some activities, including attending pre-retirement seminars/training, and participating in entrepreneurship workshops. Earlier preparations to start business firms give retirees time to learn, understand and re-adjust to business practices and environment. Venturing into business activities can be a new practice to retirees. Adequate time is required to scan the business environment and plan accordingly. According to $[5,6]$, short duration used by retirees for adjusting to the business community is among the factors for low business venture performance.

\section{Conclusions and implications}

The goal of the study was to provide an understanding of entrepreneurial performance among retired public servants in a developing country context. 
The study is unique in one main front. Unlike most earlier studies, the present study examined the entrepreneurial behaviors of the retired public servants. For most of these people, establishing new business ventures becomes a necessity for coping with post-retirement life. More specifically, the study examined the motivation and performance and factors associated with it.

The study explored the main motivation to establish business ventures. Prominent among the motivations was the availability of financial capital. Certainly, most retired public servants become entrepreneurs after being triggered by the lump sum pension. They might not have planned for the entrepreneurial endeavor. Other main motives were the availability of markets for the products intended for sale and business knowledge or experience. On the whole, the study indicates that retired public servants were motivated by internal factors or simply the pull factors.

The study further established that the majority of businesses owned by retired public servants are not performing well. The majority of entrepreneurs recorded a loss for three consecutive years. Consistent with previous studies, our study showed that retired public servant engaging in business tend to perform poorly. To understand why some business made a profit while others made the loss, the study analyzed factors influencing business performance. It was established that age of a retiree at the business start-up, and lump-sum pension as a source of start-up capital are associated with a low probability of entrepreneurial success. Education level and adequate planning before retirement increase the probability of achieving high performance.

The findings imply that employers and pension funds need to establish retirement planning programs to enhance post-retirement career, aiming to assist employees in post-retirement life. Also, the government should introduce a compulsory pre-retirement training program for public servants to equip employees with requisite skills and knowledge to venture into unfamiliar career zones. Moreover, public servants should embrace a saving culture while still in employment.

\section{Author details}

Anselm Namala ${ }^{1}$ and Mursali A. Milanzi ${ }^{2 *}$

1 Lead Consultant-Retirement Planning Tanzania Global Learning Agency (TaGLA), Dar es Salaam, Tanzania

2 Mzumbe University, Tanzania

*Address all correspondence to: mamilanzi@mzumbe.ac.tz

IntechOpen

(C) 2020 The Author(s). Licensee IntechOpen. This chapter is distributed under the terms of the Creative Commons Attribution License (http://creativecommons.org/licenses/ by/3.0), which permits unrestricted use, distribution, and reproduction in any medium, provided the original work is properly cited. (cc) BY 


\section{References}

[1] Retirement Benefits Authority [RBA]. (2004). Pensioners Survey. Nairobi: Retirement Benefits Authority.

[2] Isaga, N., Masurel, E and van Montfort, K. (2015). Owner-manager motives and growth of SMEs in developing countries. Journal of Entrepreneurship in Emerging Economies, 7 (3): 190-211. https://doi.org/10.1108/ JEEE-11-2014-0043

[3] Robichaud, Y., McGraw, E., Cachon, J., Bolton, D., Codina, J and Eccius-wellmann, C. (2013). Female entrepreneurs' motives and SMEs growth: an international study. Journal of Women's Entrepreneurship and Education, 3(4): 1-27.

[4] Robichaud, Y., Cachon, J., Taghzouti, A., Assaidi, A., and Codina, J. (2019). Entrepreneurial motives in two emerging economies: a comparison between urban Mexico and Morocco. Mediterranean Journal of Social Sciences, 10(1):141-159. Doi: 10.2478/ mjss-2019-0014

[5] Shiamwama, S. M. (2014). Internal factors affecting perfomance of businesses of retirees in Kakamega. International Journal of Business Humanities and Technology, 4(2): 144-157.

[6] Kodia, K. (2014). Factors affecting performance of businesses of public corporation retirees in Kenya: A case of Kisumu city. European Journal of Business and Management, 6(18): 1-10. http://ir.jooust.ac.ke:8080/xmlui/ handle/123456789/2996

[7] Jamil, N., Nasah, C.R.J. and Hassan, Z. (2014). The feasibility of entrepreneurship after retirement. Malaysian Journal of Business and Economics, 1(1): 19-33.
[8] Retirement Benefits Authority [RBA]. (2005). Pensioners Survey Report. Nairobi: Retirement Benefits Authority.

[9] Bukwimba, M. L. (2016). The Impact of pensions on mean residual income life-time of retirees in Tanzania. International Journal of Advanced and Multidisciplinary Social Science, 1(1): 1-10. https://doi.org/10.31426/ ijamsr.2020.3.4.3211

[10] Penrose, E. T. 1959. The Theory of the Growth of the Firm. John Wiley, New York.

[11] Wernerfelt, B. (1984). A Resourcebased view of the firm. Strategic Management Journal, 5(2): 171-180. https://doi.org/10.1002/smj.4250050207

[12] Wernefelt, B. (1989). From critical resources to corporate strategy. Journal of General Management, 14(3): 4-12. https://doi. org/10.1177/030630708901400301

[13] Barney, J. B. (1991). Firm resources and sustained competitive advantage. Journal of Management, 17: 99-120. https://doi. org/10.1177/014920639101700108

[14] Teece, D. J., G. Pisano, A. Shuen. 1997. Dynamic capabilities and strategic management. Strategic Management Journal, 18(7): 509-533. https://doi.org/10.1002/(SICI)10970266(199708)18:7<509::AIDSMJ882>3.0.CO;2-Z

[15] Peteraf, M. A. 1993. The cornerstones of competitive advantage: A resource-based view. Strategic Management Journal, 14(3): 179-191. https://doi.org/10.1002/smj.4250140303

[16] Wade, M. and Hulland, J. (2004). The resource-based view and information systems research: review, 
extension, and suggestions for future research. MIS Quarterly, 28 (1): 107-142.

[17] Musyoka, E. (2013). Do

Entrepreneurship skills have an influence on performance of women-owned entereprises in Africa. Dar es Salaam.

[18] Sanjuq, D. (2013). The impact of internal environment elements on organisational commitment. An applied study in Social Security Corporation in RSA. European Journal of Business Management, 3(8): 2004-2014.

[19] Kothari, C. (2012). Research methodology: methods and techniques (New Ed). New Delhi: New Age International Publisher.

[20] Hill, R. (1998). What Sample Size is Enough in Internet Survey Research. E-Journal for the 21st Century, 6: 3-4

[21] Yamin, M, Sinkovics, R. R, and Hadjielias, E. (2007). EU harmonization, managerial perceptions and SME export behavior. Journal of Euromarketing, 17(1): 7-21. https://doi. org/10.1300/J037v17n01_02

[22] Makoye, E.B. and Milanzi, M.A. (2019). Contract farming exit intention: evidence from smallholder tobacco farmers in Urambo, Tanzania. Rural Planning Journal, 21 (1): 1-19.

[23] Sekaran, U. and Bougie, R. (2016). "Research methods for business: a skillbuilding approach". $7^{\text {th }}$ edition, John Wiley \& Sons Ltd, Italy.

[24] Pei, X., Wu, T., Guo, J., and $\mathrm{Hu}$, J. (2020). Relationship between entrepreneurial team characteristics and venture performance in China: from the aspects of cognition and behaviours. Sustainability, 12 (377): 1-15. https://doi. org/10.3390/su12010377

[25] Aprile, M. C. and Fiorillo, D. (2017). Water conservation behaviour and environmental concern: Evidence from a representative sample of Italy individuals. Journal of Cleaner Production, 159(15): 119-129. https://doi. org/10.1016/j.jclepro.2017.05.036

[26] Adams, C. (2002). Prism reform. Financial Management, 2(12): 28-31.

[27] Emmanuel B. C., Tesha, D and Mwaitenda, S. (2020). Barriers and motives for entrepreneurship in building construction industry in Dar es Salaam, Tanzania. International Journal of Construction Engineering and Management, 9 (2): 45-62. DOI:10.5923/j. ijcem.202

[28] Minniti, M.; Arenius, P.; Langowitz, N. (2004). Global entrepreneurship monitor: 2004 report of women and entrepreneurship. Wellesley MA: The Center for Women's Leadership at Babson College.

[29] Wooldridge, J.M. (2009).

Introductory Econometrics: A Modern Approach. 4th Edition, South-Western College Publishing, Cengage Learning, Boston

[30] Goktas, A., and Cakmakyapan, S. (2013). A comparison of binary Logit and Probit models with a simulation study. JSES, 2(1): 12-15.

[31] Long, J. S. and Freese, J. (2001). Regression models of categorical dependent variables using STATA. Texas. A STATA Press Publication.

[32] URT. (2003). Small and Medium Enterprises (SME) Development Policy. Dar es Salam. Ministry of Industry and Trade.

[33] Mashenene, R. G. and Rumanyika, J. (2016). Business constraints and potential growth of SME in Tanzania: A Review. European Journal of Business and Management, 6(32): 1-9. http://hdl. handle.net/20.500.12018/165 
[34] Armstrong, F. G. (2005). Human Resource Management Practice. London: Kogan Page Publishers.

[35] Clover, T. A., and Darroch, M. G. (2005). Owners' perceptions of factors that constrain the survival and growth of small, medium and micro agribusinesses in KwaZulu Natal, South Africa. Kwa Zulu Natal: University of Kwa Zulu Natal.

[36] Atieno, S. (2009). Decentralization of financial management systems: Its implications and impact on Kenya's health care delivery. Institute of Policy Analysis and Research. Nairobi: IPAR. 


\title{
The End of the Retirement "Age": How the New World of Work Is Transforming the Old World of Retirement
}

\author{
Veronica Sheen
}

\begin{abstract}
The nature of work is undergoing fundamental transformation in the twentyfirst century with drivers including digitalization, automation, and new forms of work organization. This chapter explores how the concept of retirement itself is increasingly redundant in relation to the new world of work. Of course, working lives inevitably do come to an end, but for whom, and at what point, and under what personal and social financial conditions, is this end point? Many people will want, and be required by public policy, to continue their working lives well into later life. In addition, the new dynamics of work and employment unfolding may enable this later life engagement. But in the "post-work" world predicted by many scholars, will later life employment be a possibility for them, and even for many people in their middle and younger years? This chapter explores the implications of the future of work for how traditional models of working lives and retirement need to be restructured and examines the one vital reform to ensure everyone can sustain a decent life in the new highly volatile world of work.
\end{abstract}

Keywords: future of work, digitization, automation, retirement, income, health, inequality

\section{Introduction}

If you are in the early stages of your working life, how do you envisage that it will end? Do you see yourself reaching 65 after 40 plus years in a steady job and then a grand exit with a gold watch and a good pension in honor of your years of service? I hardly think so. Few of us well down the track of our working lives hold that vision as the world of work has dramatically changed in recent decades and holds few if any of the promises it might have held in the so-called "golden age" of post WW2 full employment-for some. And by the 1980s, the old model of working life, of permanent full-time work, over the very long term often with one employer ${ }^{1}$, was on its way out as business models were undergoing fundamental change, and work itself, was in a transitional phase in the post-industrial era.

\footnotetext{
${ }^{1}$ Mostly for men in full time employment. Women in work were also more likely to be in full-time work also but their overall participation rates were low and only began to increase in the 1970s [1].
} 
Over the 1980s and 1990s, many older workers would be made redundant at a relatively young age, often in their mid-50s as businesses restructured in a globalized economy involving new business models and much out-sourcing to cheap labor countries in the new era of global supply chains [2], p. 132. Although there was a massive transition to service sector employment, this era also ushered in much restructuring of the public sector through privatization ${ }^{2}$ which affected opportunities for secure, well-paying jobs especially for women [3]. Some of the retrenched workers of this era would get by with redundancy packages, others would have to rely on government benefits ${ }^{3}$ and a few would go on to some other work but largely not the work they left behind, and with overall lower wages and conditions. The ousting of older workers during these decades was also a means of opening opportunities for younger workers and reducing overall levels of unemployment in that era [4], p. 9.

Since the start of the twenty-first century, change in our working lives has accelerated. Digitalization and automation are catching up with our jobs in various ways or may even have abolished them. We may be self-employed, perhaps using on-line platforms, or working on a contract or casual basis. For a few, there are some benefits of flexibility but for the majority, permanent, secure employment with good wages and well-regulated working conditions has become increasingly scarce as has been widely researched and documented. In essence, the nature of our working lives has changed and is in process of further change through new technologies and the way that work is organized. These dynamics are reshaping people's lives in many ways. The old pattern of entering the workforce as a young adult, finding a good "job" or a series of "good" jobs sustained over several decades of an adult life culminating in retirement at a standard age has come to the end for many of us. It never was a trajectory that applied to the majority of women and minority groups and it was only ever an "industrial" era ${ }^{4}$ construct that is increasingly irrelevant in the "post-industrial" era".

The question here is what the unfolding "future of work" means for our pathways into retirement. There is a further question, and perhaps more important, that this chapter takes on-is retirement a relevant concept in the twenty-first century at all? Of course, all working lives come to an end-as our lives do. But how and when that end is orchestrated is the big question as the old models of working lives are eliminated. I argue that in this context, retirement is not really a relevant concept at all. The idea of retirement is past its "use by" date. It is more useful for us to explore a very different model of working life, particularly in relation to aging, a theme to be taken up in more detail further on.

With increased life expectancy and population aging, many countries are increasing retirement ages ${ }^{6}$ [5]. In some countries the increase will be quite steep with the Netherlands and Denmark lifting the retirement age from the mid-60s to 71 and 74, respectively, over coming decades in line with predictions of life expectancy. For other countries including Australia and the United Kingdom, it is a more modest rise from mid-60s to 67 and 68 in the next few years. A few countries, including Canada and Japan ${ }^{7}$ are opting for no or minuscule change leaving the retirement age in the mid-60s as at present [6].

The objective for governments in the policy of increased retirement age is, of course, to maintain the size of the labor force and levels of income tax, and to

\footnotetext{
2 This is a key theme of the 2018 World Inequality Report. https://wir2018.wid.world/

${ }^{3}$ Many on disability pensions as a result of injuries from manual labor.

${ }^{4}$ Industrial era employment can be characterized as a highly regulated form of employment with a unionized labour force.

${ }^{5}$ Post-industrial relates to a service sector economy with low levels of unionization.

6 This is defined by pension eligibility.

7 Some countries including Japan are equilibrating male and female retirement ages.
} 
minimize public expenditures associated with population aging. The days of excluding older workers for the benefit of younger workers as in the 1980s and 1990s are over. There is a determination that older workers maintain employment under the auspices of "productive aging" with the objective of increasing tolerance of an aging population and minimizing the perspective that the older population has a leisured life supported by the younger population $[7,8]$.

But are these later retirement ages, and insistence on prolonged working lives, consistent with the new and emerging world of work? A mandated retirement age, determined by government policy and access to certain pension benefits, does not automatically mean that older workers will be able to maintain their employment until that age. This will depend on availability of jobs, whether older workers can do those jobs, and perhaps in the context of an ongoing preference for younger workers-age discrimination. There has been much speculation as to the loss of jobs with digitalization and automation in the order of $40-50 \%$ over the next two decades $[9,10]$. But there is also a stream of predictions of both job loss and job creation in train [11-13]. This may mean a shift in skill requirements but may also come with other impediments to older workers participation.

And there is another larger scenario-is retirement a life stage that remains relevant in the emerging world of work? Retirement was always essentially an industrial era social construction when employment became highly regulated with strong trade unions as intermediaries negotiating the employment conditions of large contingents of workers in factories and offices [1]. But this is not the structure of much employment in the twenty-first century. Large organizations, whether private or public, aim to reduce direct employment. Ever more workers are located in small contracted out enterprises and workers have little guarantee of ongoing employment for the very long term. As a result, membership of trade unions has greatly reduced, undermining their capacities to negotiate better wages and conditions. Indeed, wage stagnation has been a core feature of many countries including the UK, Australia and the USA over the last 15 years. Excess capacity in the labor market and low inflation have also been identified as important factors contributing to this outcome [14], p. 1.

In this chapter, I explore three of the most crucial implications of the "future of work" that are unfolding and that will impact on our ideas and experience of retirement. The first relates to the ongoing loss of standard, middle level jobs that enabled workers a continuous trajectory over their working lives ending in a retirement at a designated age and eligibility for pension incomes. The second implication relates to the fracturing of our old concepts of jobs and employment as new technologies not only replace us through automation, but also restructure the organization and allocation of work in ways that are profoundly disruptive across our lives. But we must also consider that technology may make work easier and create opportunities for ongoing employment into later life that might not have been possible in the past. The third implication relates to how we generate satisfactory income across the life course and into later life, given the destruction of the traditional channels of working life into retirement. The social model involving core elements of raising a family, home ownership and other significant acquisitions related to a good quality life, as well as saving for retirement, is on unstable ground in the new world of work. What is needed to ensure adequate income across the life course?

\section{The loss of secure jobs and growing inequality}

It is curious that governments around the world are intent on increasing the age of retirement defined as pension eligibility, in response to aging populations and increased life expectancy, but take little or no account of the core factor affecting retirement-long-term trends in employment. Essentially, it is these that affect a 
worker's capacity to continue on in paid employment to a later age. In the 1980 s and 1990s, when there were insufficient jobs for new entrants, there was a massive push for the exodus of older workers with the normalization of retirement ages in the 50s in many developed countries. How different then is the twenty-first century labor market in its early decades?

The great transition in the world of work since the 1980s has been the growth of "non-standard" employment-temporary, part-time, contract and self-employment-which account for more than one in three jobs in OECD countries [15], p. 9. In Australia from where I am writing, the calculation is in the order of $40-50 \%$ based on broader criteria of job insecurity than used by the OECD. I suspect these calculations would be applicable in many other countries $[16,17]$ What is pivotal in understanding "standard" employment is that it is a "relationship" between an employer and a worker that is subject to regulation over core dimensions of working hours, wages, leave provisions and occupational safety. It emerged in the industrialization era and reached its peak in the post-war period [18], p. 10. But in the twenty-first century it is the relationship between workers and employers that has broken and is now termed "non-standard." Even though some employment may still have broad characteristics as standard employment, and which is highly regulated, there is little promise of the type of continuity and stability that existed in the post war period up to the 1980s.

In the twenty-first century, all employment is characterized by fluidity and insecurity in the face of globalization, government austerity, and mutating business models, in addition to new technologies. These factors are all geared to an objective to reduce labor costs, maximize flexibility, and any sort of long term obligation to workers. This has been a subject of broad scholarship over the past 30 years [19-22]. The post-war model of standard and secure employment was a core factor in industrialized economies of creating, for a brief period, more egalitarian societies, marked by opportunities for upward mobility from lower echelons of the social and economic hierarchies to the middle. The loss of such opportunities with the decline of the type of employment that enable this, has been a key trigger for the growth in inequality since the 1980s as widely documented [23-25]. It is also a core area of analysis by international agencies such as the OECD $[5,15]$ and the ILO [18].

These long-term trends in employment and inequality have served to erode worker solidarity and power through unions that was so important in the industrialization period in western economies in attaining decent working conditions and good wages [26], p. 57, [18]. Also, the sheer abundance of workers wanting work, or more work if underemployed, puts employers in a powerful position to minimize wages and working conditions [17], p. 3. Indeed, as much research including my own attests, insecure work isolates workers from each other and thrusts them into competition with each other contributing to a downward spiral in working conditions.

But what are the implications for retirement? If it is increasingly hard to find a good job that pays a good income in one's prime years, surely that is a reason of its own to continue to keep working for longer to make up the shortfall and to justify a later pension age. However, it is not just that more jobs are low paid and insecure with reduced upward mobility opportunity. They are also difficult to sustain over the very long term and contain a high probability of job loss especially for older workers as large-scale longitudinal studies undertaken in Australia show [27, 28].

Since the global financial crisis of 2008, there has been a reduction in overall unemployment and rising participation rates for older workers across OECD countries [4], p. 6. But the growth of low paid, low quality jobs still poses a significant barrier to later life employment. Work intensification, on-the-job surveillance and performance monitoring and the negation of any potential for the worker's 
control over the work process itself causes stress and alienation reducing potential for continuity for the long term as many studies have shown [29-32]. It may be the case that there is overall a greater proportion of older people in the workforce now but this does not mean that there will be a strong capacity for ongoing employment well into later life.

Of course, not all jobs are low quality and low paid, which make it so hard to continue on. Even many higher quality jobs can be extremely demanding and difficult to sustain over the long term as ever higher performance outputs are imposed. Occupations with large workforces including teaching and nursing professions are prime examples of this. There is considerable evidence that both are facing an emerging crisis of exit which does not bode well for longer working lives ${ }^{8}$. While neither occupations may be particularly susceptible to automation or replacement by robots in the medium term, they are nevertheless susceptible to the type of intensification, monitoring and surveillance, aided by computer technologies exactly what make the lives of Amazon warehouse workers so hard [30, 33].

\section{The future of work and taskification}

While much of the speculation about the future of work relates to questions of job loss and job creation, there are larger questions about work, employment and jobs (as specific concepts) which are in themselves in transformation. This transformation has the potential to make working in later life both easier and more difficult depending on various factors.

There is nothing intrinsically fixed about what we consider to be a job. A job is a construction of tasks and activities that can easily be dismantled which is in fact the etymology of the word itself in English-a set of tasks for a defined period. But ever more jobs are broken down into their constituent elements in a process of "taskification" $[2,13]$.

There is clear evidence in the here and now, that the future of work is not at all conducive to the type of retirement pathways assumed in national retirement policies for later pension ages. For many people the trajectory over the working life into the future is likely to encompass a high level of fragmentation and risk of collapse in later years, regardless of skill level and qualifications. They will have little power to resolve the crises they face of their own accord. Essentially, the future of work is a future that is highly unpredictable and, in another sense, it is randomized with winners and losers but no one knows who that will be. Merit has proven to be a wholly unreliable means of assessing who will be the winners and losers from the unfolding world of work [34-36].

The most highly paid and asset rich, often the same these days, as Piketty observes, [24], p. 395 will be able to retire as they wish, as they will have the financial means to do so. In essence, pension eligibility access and retirement policies are largely irrelevant to this group. They may also choose to continue their working lives well into their later years because of the high level of satisfaction their work yields. People whose work encompasses authority such as politicians and judges have always been well represented in this group. Pat Thane notes how dictators keep going to their dying breath if they can [1], p. 46. But others may also maintain their working lives if their work involves creativity, or some other form of satisfying

\footnotetext{
${ }^{8}$ Examples are cited in these articles in The Conversation - https://theconversation.com/burnt-outand-overworked-australias-nurses-and-midwives-consider-leaving-profession-66141 https://www. theguardian.com/education/2018/may/13/teacher-burnout-shortages-recruitment-problems-budgetcuts[viewed April 2020]
} 
element, and a high level of control that is not too much of a strain and indeed which actively promotes their well-being.

New technologies may also harbor possibilities for ongoing work into later ages as through the online platforms which enable work to be done where, when and how much one wishes. This may be especially viable for people with specialized and high-demand skills. There will nevertheless be massive competition for much platform work, both within countries and with workers in low wage countries making it a limited option for many [2].

The upper-end professions and occupations such as doctors, lawyers, teachers and accountants, are always promoted as avenues to ensure employment in the new world of work. But even the safety of these is called into question in analysis by Susskind and Susskind [37,38]. These scholars argue that in the short to medium term for professionals, new technologies will ever more "streamline and optimize their traditional ways of working." But for the long term, new technologies will "substitute" and effectively replace professionals [37], p. 125, through a variety of means but especially through the breakdown of professional work into its composite tasks and activities that can be routinized and automated [37], p. 128_exactly as in lower-skill jobs and occupations.

One of these authors, Daniel Susskind, has taken forward this analysis of the future of professions, in a book published in early 2020, A World Without Work: Technology, Automation and How We Should Respond. He makes the compelling case that vast areas of work will be overtaken by new technologies in the twenty-first century. He says "machines will not do everything in the future, but they will do more. And as they slowly but relentlessly, take on more and more tasks, human beings will be forced to retreat to an ever-shrinking set of activities” [39], p. 3.

Much is made of the need for people to undertake reskilling and upskilling in the name of "flexibility" in the emerging world of work. This is an argument put forward by Australian consulting group AlphaBeta for Google Australia [40] which emphasizes the need for ongoing retraining into later life especially in the workplace itself. But given that there is a breakdown in the traditional workplace, the growth of non-standard employment, and even the transformation of safe-haven professional work this may not be a realistic proposition for many [37].

Nevertheless, there will be pathways for ongoing engagement in the world of work in one way or another as we age. The report of the innovative Oxford think tank NESTA in its report The Future of Skills: Employment in 2030 gives a insight into the transitions taking place and the skills that will be at a premium. They emphasize the growth in personal service occupations especially important with aging populations, and in trade areas, such as electricians who must service households. Such occupations are not at all amenable to automation. Intriguingly they say: We show that the future workforce will need broad-based knowledge in addition to the more specialized features that will be needed for specific occupations [11], p. 14. Their list of such knowledge areas includes English language, history, philosophy, management and administration. They also show the importance of complementarity between skill areas-such as foreign languages for specialized STEM occupations. What is so persuasive about this way of thinking about future skills is that it empowers workers, to find multiple avenues to be and remain relevant in a technology-driven world of work as we age.

\section{The end of retirement and income provision implications}

It is a difficult thing to say but my conclusion is that retirement should be abolished. It should be abolished in tandem with the major transformations of 
what constitutes work and employment now taking place in the technology-driven world of work of the twenty-first century. There are no longer guarantees of the type of jobs and employment on which retirement ideals and public policy continue to be hinged. Across the life course, there will be peaks and troughs in working lives depending on a variety of factors related to technological advances, and other unpredictable factors, over which effectively no one will have any control ${ }^{9}$. There have always been peaks and troughs over people's working lives related to raising children, ill-health and disability, and caring, as well as in educational activities. I argue that the divide between working life and retirement is equally an artificial one that has lost relevance in post-industrial society.

Ongoing employment into later life will emerge as a possibility for some people perhaps a lot of people, but will not be a possibility for at least a significant minority and potentially, a majority. I will mention the case of a relative who retired a few years ago from her part-time job in a department store selling high quality porcelain ware. She loved that job and was sad to give it away-aged 82! But this may not be an option for many on the grounds of availability of suitable jobs and whether they can continue to carry the load of employment into later life with reduced health, strength, and capability in an intensive work environment. It is hard to see, at this point in time, that much employment would ever adapt to the needs of aging workers. Why would employers bother when there is a surplus of younger workers all over the world and the potential of technology to do the jobs?

The most vital argument though is that the structure of jobs, the workplace and employment is in process of being obliterated in the new world of work. This is what many commentators term the "post-work" world [39, 41, 42]. It is imperative then that work-retirement divisions be pro-actively abolished. You might have the good fortune to find a job or occupation that goes on and on, as the one my relative did. But this is not going to be the outcome for most people as Daniel Susskind points out in his new book $A$ World Without Work [39]. The trajectory will be highly variable based on luck and opportunity over which an individual will have little or no control.

This massive transition means that the opportunity for the acquisition of a sustained income over an adult life from paid employment to cover the essentials for a decent life, will increasingly fail to hold together for many people. Governments need to recalibrate the fundamental economic model of income provision. The case then is for a universal basic income (UBI). This is not an option that I have come to lightly and indeed have had serious reservations about it. But in reviewing the most current literature and thinking about the future of work, the case for it is overwhelming. Its potential weaknesses will need to be dealt with and overcome.

A universal basic income eliminates the need for specialized aged pension access rights through retirement age policy stipulations. The UBI would be accessible to all and ensure adequate income for everyone regardless of workforce status and engagement. It also obliterates the hopelessly inadequate, inappropriate and stigmatizing welfare state provisions such as in relation to unemployment, disability, or single parent status. The contemporary welfare states in the UK, USA and Australia have drifted into a role of punishment and control of many citizens for no more or less reason than the economic systems, and associated opportunities for employment, have failed them [43-45].

At this point with the future of work unfolding, these systems of targeted income support are on track for systematic failures to provide populations with what they need to survive and thrive-and equally to deal with the overarching

\footnotetext{
${ }^{9}$ At the time of writing this chapter, the corona virus pandemic has caused mass unemployment over just a few weeks pushing the world economy into unchartered territory.
} 
threat of catastrophic climate change ${ }^{10}$. Already, many people's working lives are characterized by volatility and risk regardless of how much training and upskilling they have done. An important advantage of a UBI is that it deletes the relevance of retirement and an unnecessary ageist divide in populations. People will have varying associations with employment over their lives with peaks and troughs. It may extend into their 80 s or even 90 s. But it may come to its end point earlier on, say in one's 50s, as it did in the 1980s and 1990s with the massive restructuring in the transition to post-industrial, globalized, service economies.

There are various other important reasons to implement a UBI as put forward by Guy Standing in his book, Basic Income: And How We Can Make it Happen [46] including restoring human rights, reducing poverty and inequality, and stimulating economic growth. He discusses the positive outcomes from experiments that have been conducted in different settings around the world. One of the most important of these outcomes is that a UBI actually stimulates people in going forward in their lives through work and employment such as starting a business. This in turn can generate economic growth and the revenues to fund a UBI.

My greatest concern with a UBI is that it may further solidify and exacerbate inequality especially as people grower older and for certain groups. Could there be a scenario whereby a portion of the population is effectively discarded with a UBI as a token means of (very) basic support while other portions easily continue their wealth and income accumulation? In this way there may also be a danger that there is less social mobility and moreover, a bitter divide consolidated between workers and non-workers stemming back to old puritan "work ethic" values regardless of how much digitalization, automation and robots might be wiping out and modifying vast portions of jobs.

Indeed, these concerns are echoed by Srincek and Williams who say that the "demand for a UBI is, however, subject to competing hegemonic forces. It is just as open to being mobilized for a libertarian dystopia as for a post-work society" [42], p. 119. To counter the dystopian potential of a UBI they insist that welfare states be revived in which a UBI is a supplement. The revival of the welfare state would mean appropriate targeted assistance to those in need, the end of punitive conditionality, and the end of privatized services that now administer social welfare in various guises with a central aim of profiteering. It means the revitalization of, and investment in social housing to overcome the risks of homelessness that many older people, especially women, now face because of the volatility and risk of employment [47].

\section{Conclusion}

In the emerging world of work and the society that is unfolding, there is no ongoing purpose of the work-retirement divide. In fact, the salient distinction in the twenty-first century world of work is really a crystallization of some very unpleasant and undesirable divisions. The first of these, relate to those forced to work on in jobs that are very difficult with significant health risks while others have work and occupations that are pleasant, satisfying and sustainable. The second division then relates to those who have had some luck or privilege in a working life trajectory that has enabled the accumulation of wealth so that they can withdraw as they wish while others whose working lives have been much more precarious, will not have had this same opportunity for wealth accumulation. These divisions

\footnotetext{
${ }^{10}$ As a writer in Melbourne, Australia, I know too well the devastation of the 2019-2020 fires on vast areas of bushland in south-eastern Australia caused by prolonged drought induced by climate change.
} 
The End of the Retirement "Age": How the New World of Work Is Transforming the Old World... DOI: http://dx.doi.org/10.5772/intechopen.92273

need to be closed. The abolition of retirement and introduction of a universal basic income in association with a rejuvenated welfare state will be important means of achieving this.

\section{Author details}

Veronica Sheen

Independent Researcher, Formerly Monash University, Melbourne, Australia

*Address all correspondence to: veronicasheen@fastmail.net

\section{IntechOpen}

(C) 2020 The Author(s). Licensee IntechOpen. This chapter is distributed under the terms of the Creative Commons Attribution License (http://creativecommons.org/licenses/ by/3.0), which permits unrestricted use, distribution, and reproduction in any medium, provided the original work is properly cited. (cc) BY 


\section{References}

[1] Thane P. Chapter 3: The history of retirement. In: Clark GL, Munnell A, Williams K, Orszag J, editors. The Oxford Handbook of Pensions and Retirement Income, Vol. 13. London: Oxford University Press; 2006

[2] Standing G. Taskers in the Precariat, in Paus E [Ed] Confronting Dystopia: The New Technological Revolution and the Future of Work. New York: Cornell University Press; 2018

[3] Alvaredo F, Chancel L, Piketty T, Saez E, Zucman G. World Inequality Report, World Inequality Lab. 2018. -Available from: https://wir2018.wid. world/ [Accessed: April 2020]

[4] Geppert C et al. Labour supply of older people in advanced economies: The impact of changes to statutory retirement ages. OECD Economics Department Working Papers, No. 1554. Paris: OECD Publishing. 2019

[5] OECD. Working Better with Age, Ageing and Employment Policies. Paris: OECD Publishing; 2019a. DOI: 10.1787/ c4d4f66a-en

[6] OECD, Pensions at a Glance. 2020. Available from: https://stats.oecd. org/Index.aspx?DataSetCode $=$ PAG [Accessed: April 2020]

[7] Taylor P. Working longer may be good public policy, but it is not necessarily good for older people. Journal of Aging \& Social Policy. 2019;31(2):99-105. DOI: 10.1080/08959420.2019.1576487

[8] Taylor P, Earl C. The social construction of retirement and evolving policy discourse of working longer. Journal of Social Policy. 2016;45(2):251-268

[9] CEDA, Committee for Economic Development of Australia. Australia's
Future Workforce? Melbourne: CEDA, Committee for Economic Development of Australia; 2015

[10] Frey C, Osborne M. The Future of Employment: How Susceptible Are Jobs to Computerisation? Oxford Martin School, University of Oxford. Available from: https://www.oxfordmartin. ox.ac.uk/downloads/academic/The_ Future_of_Employment.pdf [Accessed: February 2020]

[11] Bakhshi H, Downing J, Osborne M, Schneider P. The Future of Skills: Employment in 2030. London: Pearson and NESTA; 2017

[12] Frey C. The technology trapcapital, labor, and power in the age of automation. Princeton: Princeton University Press; 2019

[13] Huws U. The Future of Work: Neither Utopias nor Dystopias but New Fields of Accumulation and Struggle. 21 February 2017, transform! 2017. Europe. Available from: https://www.transformnetwork.net/en/publications/yearbook/ overview/article/yearbook-2017/ the-future-of-work-neither-utopiasnor-dystopias-but-new-fields-ofaccumulation-and-struggle/ [Accessed: April 2020]

[14] Gilfillan G. The Extent and Causes of the Wage Growth Slowdown in Australia. Australian Parliamentary Library. Available from: https:// www.aph.gov.au/About_Parliament/ Parliamentary_Departments/

Parliamentary_Library/pubs/rp/rp1819/ WageSlowdown [Accessed April 2020]; 2019

[15] OECD. Pensions at a glance 2019: OECD and G20 Indicators. Paris: OECD Publishing; 2019b. DOI: 10.1787/ b6d3dcfc-en

[16] ACTU. Australian Council of Trade Unions. 2018: Australia's Insecure Work 
The End of the Retirement "Age": How the New World of Work Is Transforming the Old World... DOI: http://dx.doi.org/10.5772/intechopen.92273

Crisis: Fixing it for the Future. 2018.

Melbourne: ACTU [Accessed: 2020]

[17] TAI, The Australia Institute. The

Dimensions of Insecure Work: A

Factbook. Canberra: The Australia

Institute; 2018

[18] ILO, International Labour

Organisation. 2016. Non-standard

Employment Round the World.

Geneva: ILO. Available from: https://

www.ilo.org/wcmsp5/groups/public/-

--dgreports/---dcomm/---publ/

documents/publication/wcms_534326.

pdf [Accessed: April 2020]

[19] Beck U. The Brave New World of

Work. Cambridge: Polity Press; 2000

[20] Beck U. Risk Society: Towards New

Modernity. London: Sage; 1992

[21] Lipietz A. Towards a New Economic Order: PostFordism, Ecology and Democracy. Cambridge: Polity Press; 1992

[22] Munck R. Globalisation and Labour: The New Great Transformation. London/New York: Zed Books; 2002

[23] Milanovic B. Global Inequality - A New Approach to the Age of Globalization. Cambridge, MA: Harvard University Press; 2016

[24] Piketty T. Capital in the 21st Century. Cambridge, MA: Harvard University Press; 2014

[25] Stiglitz J. The Price of Inequality. New York: Norton and Company; 2012

[26] Ford M. Rise of the Robots: Technology and the Threat of a Jobless Future. New York: Basic Books; 2015

[27] Watson I. Bridges or traps? Casualisation and labour market transitions. Australia Journal of Industrial Relations. 2013;55(1):6-37
[28] Workplace Research Centre.

Australia at Work: In a Changing World. University of Sydney: Workplace Relations Centre; 2009

[29] Bloodworth J. Hired: Six Months Undercover in Low-Wage Britain. London: Atlantic Books; 2018

[30] Guendelsberger E. On the Clock: What Low-Wage Work Did to me and how it Drives America Insane. New York: Little, Brown and Company; 2019

[31] Lain D, Airey L, Loretto W, Vickerstaff S. Understanding older worker precarity: The intersecting domains of jobs, households and the welfare state. Ageing and Society. 2019;39(10):2219-2241. DOI: 10.1017/ S0144686X18001253

[32] Sheen V. The implications of Australian women's precarious employment for the later pension age. The Economic and Labour Relations Review. 2017;28(1):3-19. Sage Publishing

[33] Marmot M. Fair Australia: Social Justice and the Health Gap, 2016 Boyer Lectures. 2016. Australian Broadcasting Corporation. Available from: https:// www.abc.net.au/radionational/ programs/boyerlectures/series/2016boyer-lectures/7802472 [Accessed: April 2020]

[34] Frank R. Success and Luck: Good Fortune and the Myth of Meritocracy. Princeton: Princeton University Press; 2016

[35] Markovits D. The Meritocracy Trap: How America's Foundational Myth Feeds Inequality, Dismantles the Middle Class, and Devours the Elite. New York: Penguin Press; 2019

[36] Piketty T. Capital and Ideology. Cambridge, MA: Harvard University Press; 2020 
[37] Susskind D, Susskind R. The future of the professions. Proceedings of the American Philosophical Society. 2018;162(2). Available from: https:// www.amphilsoc.org/sites/default/ files/2018-11/attachments/Susskind\%20 and\%20Susskind.pdf [Accessed: April 2020]

[38] Susskind D, Susskind R. The Future of the Professions: How Technology Will Transform the Work of Human Experts. London: Oxford University Press; 2015

[39] Susskind D. A World without Work: Technology, Automation and How We Should Respond. London: Penguin, Allen Lane; 2020

[40] AlphaBeta Australia. Future Skills, AlphaBeta. 2019. Available from: https://www.alphabeta.com/ our-research/future-skills-report/ [Accessed: April 2020]

[41] Mason P. Post Capitalism: A Guide to Our Future. London: Penguin; 2015

[42] Srincek N, Williams A. Inventing the Future: Postcapitalism and a World without Work. London, New York: Verso; 2015

[43] Grover C. Violent proletarianisation: Social murder, the reserve army of labour and social security 'austerity' in Britain. Critical Social Policy. 2019;39(3):335-355

[44] Raffass T. Unemployment and punitive activation as human rights issues. Australian Journal of Human Rights. 2014;20(1)

[45] Raffass T. Demanding activation. Journal of Social Policy. 2017;46(2). Cambridge University Press

[46] Standing G. Basic Income: And How We Can Make it Happen. London: Penguin; 2017
[47] Australian Human Rights

Commission. Older Women's Risk of Homelessness: Background Paper. Canberra: Australian Human Rights Commission; 2019 



\section{Edited by Ingrid Muenstermann}

Worldwide life expectancy has increased and, as such, this book examines different aspects of aging from societal and political perspectives. Written by reputable academics working at universities around the world (Australia, New Zealand, Portugal,

Taiwan, Tanzania, Russia), this book takes a kaleidoscope view of how different societies handle their aging population. 